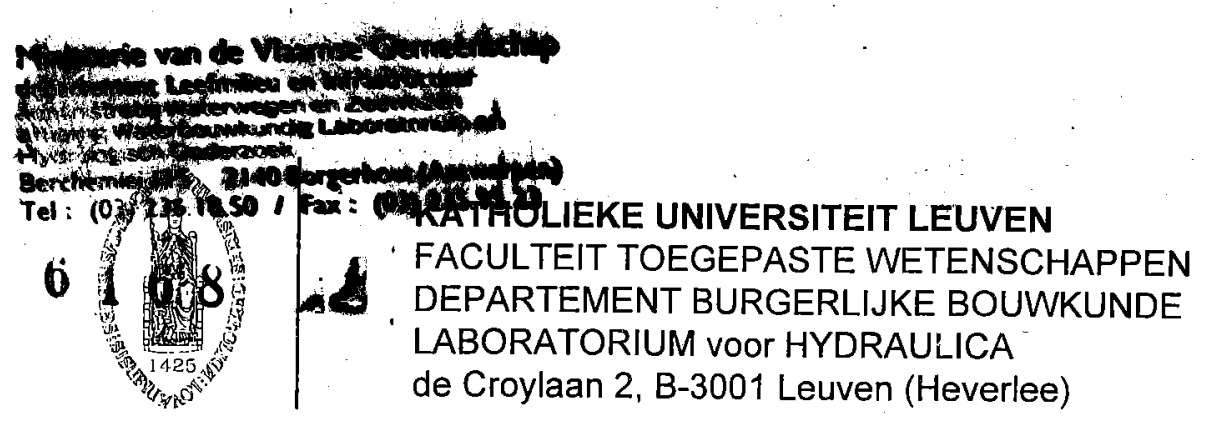

\title{
EROSION OF MUD/SAND MIXTURES
}

Promotor:

Prof. dr. ir. J. Berlamont
Proefschrift voorgedragen tot het behalen van het doctoraat in de toegepaste wetenschappen

door

Hilde TORFS. 



\section{Errata}

Page Correction

4 last line aim 6: the about the flow field

$4 \$ 3.1,3$ rd line: $a$ review

5 2nd line: used measuring-instruments and techniques used

18 4rd line: in an aquatic ...

28 last line before B.: occurring in turbulent,...

29 before eq. (2.34): resistance due to increasing ....

38 B. 1st line: estuarine environment

39 Type D: and zoogloeal...

42 3rd paragraph: Chesher et al. (1994)

42 last paragraph, 1st line: continuousty body erosion

48 3rd line: destroy the flocs

52 6th line: Halfway along the sediment ...

58 2nd line: is always ...

593 3rd paragraph, 3rd line: without destroying

66 2nd paragraph, 5th line: the build up

$67 \$ 4.2 .1$, 1st line: .. on sand beds is twofold..

79 1st paragraph, last line: or smoothing of the ...

79 2nd paragraph, 4rd line: the smoothing of the ...

79 last line: starting from pure clay

80 2nd paragraph, last line: possess the lowest ...

89 4rd line up: erosion is not continuous

102 3rd line: lifted off

105 Table 4.7: Sand content (\%)

116 Caption Figure 5.1: The percentages indicate the amount of clay in the mixture.

119 3rd line up: between wall and bed

134 2nd line up: Kaolinite was choosen

136 2nd paragraph, 2nd line: to smoothing of the bed

136 2nd paragraph, 2nd line up: in between two sand grains

138 5th line up: and smooth the surface

143 2nd paragraph, 4rd line up: larger than the floc

145 2nd paragraph, 5th line: ranging from 
(C) 1995

I.S.B.N. 90-5682-001-X 


\section{Acknowledgements}

This thesis describes the results of more than five years of experimental research on the erosion of mud/sand mixtures. Throughout this period I received help and encouragements from many people and this work would not be complete without some words expressing my sincere gratitude.

First I would like to express my deepest gratitude and appreciation to my promoter, Professor $J$. Berlamont, for his guidance and encouragements at every stage of this research.

$I$ want to extend my appreciation to the members of the reading committee, Professor E. Smets and Professor G. Govers, for their valuable comments and advice. Furthermore I want to thank Professor A. Mehta and Professor R. Ashley, who accepted to be members of the examination committee.

Most of the experimental work has been carried out in the framework of an interuniversity project funded by the Fund for Collective Fundamental Research (F.K.F.O.-project 2.9012.90). My position as a Research Assistant for the F.K.F.O. is gratefully acknowledged. I would like to thank all the partners of this project for the fruitful collaboration.

This study also benefited a great deal from the G8 Coastal Morphodynamics Programme, funded by the Commission of the European Community, Directorate General for Science, Research and Development under contract no. MAS2-CT-92-0027. The information exchange at several workshops has been very valuable and especially the intensive collaboration with Helen Williamson from HR Wallingford has been very useful.

The laboratory work would not have been possible without the help and support from Jef Kayenbergh and Bruno Meulemans; they helped me to prepare and carry out the experiments and, what is more important, they always found a solution for my practical problems. I also want to thank Professor $R$. Swennen for the use of the scanning electron microscope. 
Further I greatly appreciate the preparation of many drawings by Danny Uten, the computeradvice from Freddy Ceuppens and the careful reading of this manuscript by my brother Rudi and my colleague Erik Toorman.

In fact I want to thank all my colleagues at the Hydraulics Laboratory for the friendly atmosphere at work. I especially want to mention Anita Vermunicht and Imelda Uyttebroeck for their practical and moral support.

Finally I have to thank my family and close friends for their continuous love and support.

Leuven, September 1995

Hilde Torfs 


\section{Abstract}

The sediments found in tidal rivers, estuaries and coastal zones are usually a mixture of sand and mud. The accumulation and the erosion of these sediments have a large impact on the accessibility of harbours and on the necessary maintenance dredging operations. The ability of the mud fraction to adsorb large amounts of contaminants makes it even more important to fully understand the mixture behaviour. The sediment bed in a combined sewer system can also be described as a mixture of cohesive and cohesionless sediments. The accumulation of sediments reduces the sewer capacity and the erosion of the sediment bed can cause environmental problems when part of the flow is discharged into surface waters. Again, it is important that the behaviour of the sediment mixture is properly understood.

This thesis represents the results of over five years of laboratory experiments on the erosion of mud/sand mixtures in uniform flow. The aim was to examine the effect of the mixture composition on the behaviour of the sediment bed in uniform flow conditions. The transition from cohesionless to cohesive behaviour, with respect to erosion resistance and mode of erosion, has been studied by adding more and more cohesive sediment to sand. A critical mud content is found above which the mixture can be described as a cohesive sediment; below this limit the mixture acts like sand only. The existence of a critical mixture composition has been explained in terms of the different structures formed inside the homogeneous mixture. Furthermore, the formation of a layered bed from a mud/sand suspension was followed. The influence of the mixture composition on the sedimentation and erosion processes has been studied. The sand fraction seemed to enhance consolidation and reduce the resulting bed thickness. The erosion of the stratified deposit was a sequence of suspended load and bed load transport phases. In order to extrapolate the laboratory results to field conditions, the influence of the shape and the scale of the flume cross section on bed shear stress distributions has been studied in detail. Both the shape and the aspect ratio of the flume were found to have an important effect on secondary currents and hence on bed shear stresses. Finally, based on the results of the experimental study, some guidelines to model the erosion resistance and erosion rates of mud/sand mixtures have been formulated. 


\section{Erosie van slib/zand mengsels}

\section{Samenvatting}

\section{Inleiding}

Slib is een mengsel van water, fijne sedimentdeeltjes (kleiner dan $63 \mu \mathrm{m}$ ) en organisch materiaal. Van de fijne fractie zijn het vooral de kleimineralen (kleiner dan $2 \mu \mathrm{m}$ ) die verantwoordelijk zijn voor de cohesieve eigenschappen van het slib. Cohesie is het resultaat van een combinatie van elektrostatische aantrekkingskrachten (omwille van de ladingen op de kleiplaatjes) en Van der Waalskrachten. Het organisch materiaal zorgt voor bijkomende complexe bindingen tussen de verschillende deeltjes. Zand daarentegen is een niet-cohesief materiaal bestaande uit korrels die in grootte kunnen variëren tussen $63 \mu \mathrm{m}$ en $2 \mathrm{~mm}$. De korrels gedragen zich als individuele entiteiten; er bestaan geen onderlinge aantrekkingskrachten.

De sedimenten in tijrivieren, estuaria en kustzones zijn vaak mengsels van zand en slib. De bewegingen en het aanslibben van deze sedimenten bemoeilijken de scheepvaart, zodat belangrijke baggeroperaties noodzakelijk zijn. De baggerspecie is bovendien sterk vervuild aangezien polluenten, zoals zware metalen, zich preferentieel aan de fijne deeltjes hechten. Het is dan ook van het grootste belang het gedrag van slib/zand mengsels te kunnen voorspellen. In gemengde rioleringsstelsels treft men eveneens sedimenten aan die te omschrijven zijn als slib/zand mengsels, weliswaar met een zeer hoog gehalte aan organisch materiaal. Sedimentophopingen in rioleringen reduceren de doorvoercapaciteit van het stelsel zodat aanzienlijke onderhoudswerken moeten uitgevoerd worden. Daarenboven stroomt bij een fikse regenbui een deel van het debiet rechtstreeks naar de oppervlaktewateren via de overstorten. Door erosie van het sedimentbed komen ook sedimenten, die vervuild kunnen zijn, in het milieu 
terecht. Eens te meer blijkt er nood aan modellen die het erosiegedrag van slib/zand mengsels kunnen voorspellen.

Het experimenteel onderzoek dat aan de basis ligt van dit proefschrift is uitgevoerd in het kader van twee projecten. In 1990 startte het Belgische interuniversitaire FKFO-project 2.9012.90 dat tot doel had de "Erosie, sedimentatie en resuspensie van gedeeltelijk cohesieve, gedeeltelijk nietcohesieve sedimenten in het bijzonder in het geval van niet-permanente stroming" te bestuderen. Vijf universiteiten (K.U.Leuven, U.G., U.C.L., U.Lg en V.U.B.), het Waterbouwkundig Laboratorium van Borgerhout en het Laboratoire Hydraulique van Châtelet werkten samen aan deze studie die bestond uit een reeks laboratoriumexperimenten en in situ meetcampagnes.

Verder liep een deel van het experimentele werk in het kader van het MAST G8M Coastal Morphodynamics programma van de Europese Commissie. Het onderzoek naar de erosie van slib/zand mengsels paste in Topic 4: Cohesive Sediments.

\section{Doelstellingen van het onderzoek}

Het hoofddoel van het experimenteel onderzoek is het erosiegedrag van slib/zand mengsels in uniforme stroming beter te begrijpen en de fysische processen die aan de grondslag liggen van de verschillende erosie-mechanismen te doorgronden.

Om dit doel te bereiken worden de volgende specifieke objectieven vooropgesteld:

1. De invloed van de mengselsamenstelling op de erosieweerstand van homogene slib/zand mengsels onderzoeken door geleidelijk het gehalte aan cohesieve sedimenten te verhogen. Ook de invloed van het type cohesief materiaal zal worden nagegaan.

2. De wijze waarop een slib/zand bodem erodeert, volgen en het effect van de mengselsamenstelling nagaan. De resulterende erosiesnelheden zullen worden opgemeten met de bedoeling een relatie tussen de erosiesnelheid, de stromingsparameters, zoals de bodemschuifspanning, en de mengselkarakteristieken te ontwikkelen. 
3. Nagaan hoe een gelaagd slib/zand bed zich vormt door sedimentatie uit een homogene slib/zand suspensie en weerom de invloed van de samenstelling, c.q. het zandgehalte, bestuderen.

4. De erosieweerstand en erosiesnelheid van een dergelijke gelaagde bodem evalueren.

5. Aan de hand van de experimentele resultaten een fysische verklaring zoeken voor het erosiegedrag van slib/zand mengsels. De mechanismen die de interne structuur van het sedimentbed bepalen zullen bestudeerd worden.

6. Tenslotte, gebaseerd op de experimentele kennis, enkele richtlijnen formuleren voor het modelleren van het erosiegedrag van slib/zand mengsels. Er zal worden nagegaan welke informatie nodig is, om zinvolle voorspellingen omtrent erosie en sedimenttransport te doen, en hoe deze gegevens kunnen verkregen worden.

\section{Erosie en sedimenttransport in uniforme stroming}

Vooraleer het erosiegedrag van mengsels te bestuderen, wordt een literatuurstudie naar de huidige kennis in verband met de erosie en het transport van niet-cohesieve sedimenten en cohesieve sedimenten uitgevoerd. Deze gegevens zullen de basis vormen voor de studie van het erosiegedrag van slib/zand mengsels.

\section{Niet-cohesieve sedimenten}

De erosieweerstand van niet-cohesieve sedimenten wordt bepaald door de korrelverdeling en de vorm van het materiaal en door de stroming. De krachten die op een korrel werken, wanneer die in beweging komt, zijn de sleep- (drag) en hef- (lift) kracht en het ondergedompeld gewicht (vgl 2.1 en 2.3). Gebaseerd op deze krachtswerking werd o.a. het bekende Shieldsdiagramma opgesteld (Fig 2.2), waaruit men de kritische schuifspanning kan aflezen.

Door de turbulentie van de stroming zijn de stromingssnelheden en dus de bodemschuifspanningen (bed shear stress) niet constant maar schommelen ze rond een tijdsgemiddelde waarde. Het probleem van de bepaling van het begin van beweging van een 
zandbed wordt dan ook herleid tot de probabilistische bepaling van de kans dat in bepaalde stromingsomstandigheden een korrel zal geërodeerd worden (vgl 2.11 en 2.12).

Eens een sedimentdeeltje geërodeerd is, kan het zich voortbewegen in suspensie (suspended load) of al rollend en springend over de bodem (bed load), afhankelijk van de intensiteit van de stroming. Verscheidene empirische formules werden in de loop der jaren opgesteld, die elk sedimenttransport in bepaalde omstandigheden kunnen voorspellen. Enkele ervan werden in deze thesis kort toegelicht: Ackers en White, van Rijn, Einstein.

Een belangrijke parameter in al deze formules is de bodemschuifspanning. Zodra er bedvormen ontstaan, ribbels of duinen, is de stromingsweerstand niet alleeen een gevolg van de korrelruwheid maar ook van de vormruwheid. Het is echter enkel de korrelruwheid die bepalend is voor het sedimenttransport. De korrelschuifspanning (grain shear stress) kan berekend worden uit de totale bodemschuifspanning met behulp van de methode van Engelund-Hansen die beschreven is in vergelijkingen (2.25), (2.26) en (2.27).

\section{Cohesieve sedimenten}

In tegenstelling tot niet-cohesieve sedimenten, die volledig gekarakteriseerd kunnen worden door hun korrelverdeling, is de karakterisatie van cohesieve sedimenten veel ingewikkelder. Van der Waals en elektrostatische krachten zorgen ervoor dat deze deeltjes de neiging vertonen vlokken en aggregaten te vormen in een suspensie. De neiging tot vlokvorming neemt toe met de concentratie aan zwevend materiaal. De bezinkingssnelheid van cohesief materiaal is dan ook afhankelijk van de suspensieconcentratie. Aanvankelijk neemt de bezinkingssnelheid toe met toenemende concentratie. Wanneer het gehalte aan zwevend materiaal echter groter wordt dan $\pm 10 \mathrm{~g} / \mathrm{l}$, zal de opwaartse stroming van water, veroorzaakt door de neerwaartse beweging van de vlokken, gehinderd worden door de vele vlokken die in suspensie zijn; de bezinkinkingssnelheid daait. Zodra de deeltjes bezonken zijn, ondergaat het gevormde bed consolidatie. De aggregaten herschikken zich zodat de densiteit van het materiaal toeneemt in de tijd. 
De structuur van het cohesieve sedimentbed wordt verder beïnvloed door de aanwezigheid van biologisch materiaal. Biologische activiteit kan zowel een stabilisatie (biostabilisation) van de bodem met zich meebrengen als de bodem losser maken (bioturbation).

De parameters die het gedrag van cohesieve sedimenten bepalen, zijn dus niet alleen de fysischchemische eigenschappen van het sediment maar ook de fysisch-chemische eigenschappen van de stromende vloeistof en van de poriënvloeistof, de water-bed uitwisselingsprocessen en de structuur van het sediment bed.

Verscheidene reologische modellen worden vooropgesteld om het gedrag van cohesieve bodems te beschrijven. De reologie bestudeert de stroming en vervorming van materialen. Bij een lage densiteit gedraagt het slib zich min of meer als een vloeistof en kan het stromingsgedrag beschreven worden door o.a. een pseudo-plastisch of een Bingham model (Fig 2.4). De bezwijkspanning (yield stress) van het materiaal geeft een goede aanduiding voor de erosieweerstand van het materiaal. Bij hogere densiteiten vertoont een cohesief sedimentbed typische grondmechanische eigenschappen die kunnen beschreven worden met behulp van de wet van Coulomb (Fig 2.5).

De erosie van slib kan op verschillende wijzen gebeuren. Wanneer individuele deeltjes of aggregaten uit het bovenste laagje van het bed worden meegenomen, spreekt men van oppervlakte-erosie (surface erosion). Wanneer het materiaal op een dieper gelegen vlak bezwijkt en grote delen ineens worden meegesleurd, heeft men te maken met massa-erosie (mass erosion). Als men te maken heeft met vloeibaar slib (slib met een lage densiteit, zonder inwendige structuur) dat in beweging komt door instabiliteiten van het scheidingsoppervlak slib-water, spreekt men van resuspensie van vloeibaar slib. De erosie van vloeibaar slib zal echter niet behandeld worden in dit werk.

In tegenstelling tot niet-cohesieve materialen wordt de erosieweerstand van slib in hoofdzaak bepaald door de elektrochemische krachten en niet door het verwaarloosbare gewicht van de partikels. De cohesie- en, wanneer ook andere effecten zoals organische bindingen worden beschouwd, de adhesiekrachten zijn zoals hoger vermeld van vele factoren afhankelijk. Het is daarom vrijwel onmogelijk een eenvoudig erosiecriterium voor cohesieve materialen op te stellen. Desalniettemin bestaat er een aantal veel gebruikte empirische formules die de erosieweerstand uitdrukken in functie van enkele belangrijke parameters zoals densiteit 
(vgl 2.33) en volumefractie (vgl 2.34). Weerom dient te worden opgemerkt dat het erosieproces gedomineerd wordt door stochastisch veranderende parameters en dat een probabilistische aanpak van het erosiecriterium wenselijk is.

De erosiesnelheid van een cohesieve bodem is een functie van het verschil tussen de aangelegde bodemschuifspanning en de kritische schuifspanning van het materiaal en van de materiaalkarakteristieken. Voor de oppervlakte-erosie van een bed met lage, variabele densiteit wordt meestal vergelijking (2.43) gebruikt. Wanneer de erosieweerstand niet varieert over de diepte is vergelijking (2.44) een eenvoudige benadering. Deze laatste uitdrukking wordt ook in het geval van massa-erosie toegepast.

\section{Mengsels van cohesieve en niet-cohesieve sedimenten}

Wegens hun totaal verschillende eigenschappen worden cohesieve en niet-cohesieve materialen, t.t.z. slib en zand, meestal afzonderlijk behandeld in sedimenttransportproblemen. Nochtans zijn de sedimenten die men aantreft langs de kust, in tijrivieren of in estuaria vaak een mengsel van zand en slib. De opgemeten densiteiten en mengselsamenstellingen variëren hierbij zeer sterk. Op vele plaatsen is het sedimentbed gelaagd ten gevolge van een opeenvolging van erosie- en bezinkingsperioden naar aanleiding van een storm of door de getijdewerking.

De sedimenten in gemengde rioleringsstelsels kunnen eveneens beschreven worden als mengsels van cohesieve en niet-cohesieve sedimenten. De cohesie wordt in dit geval veroorzaakt door het aan elkaar kleven van de deeltjes met teer en vetten, door chemische cementatie en door biologische processen. Reologisch onderzoek van deze rioolsedimenten heeft echter aangetoond dat men het gedrag van deze materialen kan beschrijven met de modellen die gewoonlijk voor cohesieve materialen gebruikt worden. Sterke neerslag zorgt ook hier voor een periodieke erosie en sedimentatie die het sedimentbed een gelaagde structuur bezorgt.

Verscheidene onderzoekers noteerden een toenemende erosieweerstand en afnemende erosiesnelheden wanneer de kleifractie in een mengsel toeneemt. Anderen vonden dan weer dat het toevoegen van zand aan slib de erosieweerstand doet stijgen. In de meeste gevallen werd 
echter niet alleen de samenstelling maar ook de densiteit van de mengsels gewijzigd, zodat uit deze gegevens het effect van de mengselsamenstelling alléén moeilijk in te schatten is.

\section{Experimenteel onderzoek}

De tegenstrijdige gegevens uit de literatuur vormen de aanleiding voor een grondige studie. Om het erosiegedrag van slib/zand mengsels in detail te kunnen bestuderen, wordt er beslist een fundamenteel laboratoriumonderzoek uit te voeren. Op die manier is het mogelijk de invloed van één parameter te evalueren terwijl alle andere constant gehouden worden.

De erosieproeven zijn uitgevoerd in een $9 \mathrm{~m}$ lange, rechte stroomgoot met rechthoekige doorsnede (Fig 3.1) die opgesteld staat in het Laboratorium voor Hydraulica van de K.U. Leuven. Het opwaarts reservoir sluit aan op een $4 \mathrm{~m}$ lang instroomgebied met niet-erodeerbare bodem. Hierop volgt de meetsectie, waarin een $8 \mathrm{~cm}$ dik sedimentbed, lengte $3 \mathrm{~m}$, kan geplaatst worden met behulp van losse sedimentbakken. Afwaarts van de meetsectie bevindt zich een sedimentvang gevolgd door een uitstroomzone met vaste bodem van $1.5 \mathrm{~m}$ lang.

De meetinstrumenten die voorzien worden, zijn: een elektromagnetische debietmeter; twee drukopnemers die de waterhoogte opwaarts en afwaarts van het sedimentbed registreren; een pitotbuis verbonden met een differentieel drukopnemer om snelheidsprofielen te meten; een krachtopnemer die het gecumuleerde bodemtransport weegt; en twee aftappunten, opwaarts van het sedimentbed en afwaarts van de sedimentvang, om stalen van het suspensiemateriaal te nemen. Deze monsters worden achteraf gefiltreerd om de concentratie aan zwevend materiaal te bepalen. Verder worden de samenstelling en de densiteit van het bed bepaald aan de hand van een analyse van bodemstalen die na afloop van een experiment genomen worden.

De sedimenten die gebruikt worden voor deze experimenten zijn: zand van Mol, een uniform, fijn wit zand met een gemiddelde diameter van $0.23 \mathrm{~mm}$; twee types klei, een bruine pottenbakkersklei die hoofdzakelijk bestaat uit montmorilloniet en kaoliniet; en drie verschillende soorten natuurlijk slib, gebaggerd in de Schelde nabij de haven van Antwerpen. De kleisoorten werden gebruikt om de invloed van het organisch materiaal uit te schakelen. De korrelverdelingen van al deze materialen zijn te vinden in Figuur 3.7. 
Twee types experimenten worden uitgevoerd: erosieproeven op homogene mengsels en erosieproeven op gelaagde mengsels. De homogene mengsels worden gevormd door de gewenste hoeveelheden zand, cohesief materiaal en water grondig te mengen. Nadien wordt het mengsel in de meetsectie geschept en vlakgestreken. Er volgt dan een consolidatie onder water gedurende één nacht. De densiteit van deze mengsels schommelt rond $1850 \mathrm{~kg} / \mathrm{m}^{3}$. Om de invloed van de densiteit na te gaan, worden enkele proeven gedaan met een lagere densiteit van om en bij de $1650 \mathrm{~kg} / \mathrm{m}^{3}$. Het percentage cohesief materiaal varieert van 0 tot $30 \%$.

Voor de vorming van een gelaagde bodem wordt een bezinkingstank geconstrueerd. Deze tank ( $1 \mathrm{~m} \mathrm{hoog)} \mathrm{kan} \mathrm{op} \mathrm{de} \mathrm{meetsectie} \mathrm{worden} \mathrm{bevestigd.} \mathrm{Op} \mathrm{geregelde} \mathrm{tijdstippen} \mathrm{(tweemaal} \mathrm{per} \mathrm{dag,}$ als simulatie van getijdewerking) wordt een vloeibaar mengsel van zand en slib in de tank gepompt. Een proportionele hoeveelheid wordt ook in een transparante consolidatiekolom van dezelfde hoogte gegoten. Op die manier kan de opbouw van de bodem gevolgd worden. Met behulp van een gamma-densimeter wordt dan een densiteitsprofiel van het bed in de kolom opgemeten. De initiële samenstelling en densiteit van het bed zijn voor de verscheidene experimenten gegeven in tabel 4.8 .

Wanneer een bed van $8 \mathrm{~cm}$ dikte gevormd is, door bezinking of plaatsing, wordt gestart met de erosieproeven die voor beide types van experimenten identiek verlopen. Het debiet in de goot wordt stapsgewijze opgevoerd, met intervallen van 0.5 tot 2 uur, tot er erosie optreedt. Het begin van erosie kan zowel visueel worden vastgesteld doorheen de glazen wand in de meetsectie als door middel van de resultaten van de transportmetingen. Wanneer de erosie begint, wordt het debiet nog enkele malen verhoogd. Een experiment wordt gestopt wanneer de erosie de stroming zodanig beïnvloedt dat deze niet langer als uniform kan worden beschouwd.

\section{Resultaten van het experimenteel onderzoek}

\section{Erosie van homogene mengsels}

Wanneer het aandeel aan cohesief materiaal in een homogeen mengsel, uitgedrukt als \%fines (het gewichtspercentage kleiner dan $63 \mu \mathrm{m}$ ), toeneemt, zal ook het erosieproces geleidelijk wijzigen. Zolang het percentage fijn materiaal gering blijft (slechts enkele procenten), gedraagt het 
mengsel zich als een zuiver niet-cohesief materiaal. Bij een lage bodemschuifspanning worden de fijne deeltjes uit het oppervlak weggespoeld en gaan in suspensie. Bij hogere debieten begint ook de zandfractie in beweging te komen. Het bodemtransport zorgt voor het ontstaan van de typische bedvormen zoals ribbels en duinen. Deze blijken enkel uit zand te bestaan, de fijne ongebonden deeltjes gaan onmiddellijk in suspensie. Voegt men echter nog meer fijn materiaal toe dan zal het slib/zand mengsel zich gedragen als een louter cohesief materiaal. Afhankelijk van het type cohesief materiaal en de densiteit is de erosie te beschrijven als oppervlakte-erosie of massa-erosie. Voor de mengsels met een densiteit van $1850 \mathrm{~kg} / \mathrm{m}^{3}$ worden meestal grote stukken van het bedmateriaal losgerukt. De geërodeerde kruimels hebben afmetingen die variëren van enkele millimeters tot een centimeter. Dit fenomeen is dan ook als massa-erosie bestempeld. Een ander kenmerk van de erosie van deze mengsels is dat de erosie preferentieel voortschrijdt in reeds geërodeerde zones, terwijl het begin van erosie op het ongeschonden bed heel wat moeilijker verloopt. Dit heeft te maken met de verhoogde turbulentie in en rond een erosieplek en het met hydraulische glad zijn van het oorspronkelijke bed.

De kritische schuifspanning wordt als volgt bepaald. Voor een bepaald debiet $\left(Q_{i}\right)$ en dus een bepaalde waarde van de bodemschuifspanning $\left(\tau_{i}\right)$ is er nog geen erosie waar te nemen of te meten. Bij een hoger debiet $\left(Q_{i+1}\right)$ is er wel erosie. De kritische schuifspanning wordt dan berekend als het gemiddelde van de schuifspanningen $\tau_{i}$ en $\tau_{i++}$. De op deze manier gedefinieerde erosieweerstand neemt voor alle gebruikte types cohesief materiaal toe met het gehalte aan fijne deeltjes in het mengsel (Fig 4.6, 4.7, 4.8) en deze toename is redelijk lineair te noemen. De erosieweerstand van een mengsel is steeds hoger dan die voor zand alleen. Enkel voor de allerlaagste percentages fijn materiaal wordt een lagere kritische schuifspanning opgemeten, die overeenstemt met het uitspoelen van de fijne deeltjes bij lagere debieten. Voor de mengsels met kaoliniet worden de grootste kritische schuifspanningen opgetekend, gevolgd door de mengsels met Scheldeslib en deze met montmorilloniet. De erosieweerstand van de montmorillonietmengsels stijgt zeer geleidelijk, er is bijvoorbeeld (Fig 4.9) weinig verschil in de erosiesnelheden van de $7 \%$ en $9 \%$ mengsels. Wanneer de densiteit van het mengsel verlaagd wordt of de consolidatietijd verkort, neemt de erosieweerstand af. 
Het opgemeten sedimenttransport voor de niet-cohesieve mengsels komt zeer goed overeen met de waarden voor zand alleen; men kan eenzelfde relatie gebruiken om de meetresultaten voor te stellen. Dit betekent dat de fijne fractie het transport van het zand niet verhindert.

De opgemeten erosiesnelheden voor de verschillende cohesieve mengsels zijn duidelijk een functie van het verschil tussen de bodemschuifspanning en de kritische schuifspanning. Voor de meeste mengsels is de formule voor massa-erosie toepasbaar; de gebruikte erosieconstanten stemmen goed overeen met waarden uit de literatuur. Enkel de erosie van kaolinietmengsels van lage densiteit en van de mengsels met Scheldeslib 1 kan beschreven worden met de typische uitdrukking voor oppervlakte-erosie.

. Voor de montmorillonietmengsels werd ook een overgangszone gevonden. Wanneer het percentage fijn materiaal zich tussen $7 \%$ en $13 \%$ bevindt, is het optredende erosieproces noch als cohesief noch als zandtransport te bestempelen. Ook de opgemeten erosiesnelheden en transportwaarden stemmen met geen van de vorige overeen.

\section{Gelaagde sedimentbodem}

Wanneer een sedimentbed ontstaat uit een slib/zand suspensie zal, afhankelijk van de beginvoorwaarden, het gevormde sedimentbed een sterke variatie in densiteit en samenstelling over de diepte vertonen. Als dit vormingsproces zich enkele malen herhaalt, ontstaat een gelaagde bodem. Door het gebruik van een transparante consolidatiekolom kan de opbouw van de bodem in detail worden gevolgd. Wanneer de concentratie aan cohesief materiaal in de initiële suspensie kleiner is dan het gelpunt (de concentratie waarbij een continue structuur gevormd wordt) zal de zwaardere zandfractie ongehinderd sneller kunnen bezinken en een zandlaagje op de bodem vormen. Als de oorspronkelijke suspensie reeds een structuur vormt, dan zal deze structuur verhinderen dat de zandkorrels door de slibmassa vallen. In onze experimenten was de suspensieconcentratie steeds zeer laag, zodat in iedere proef een zandlaagje gevormd werd. De segregatie van zand is echter beperkt tot een bepaalde gehalte aan zand in het mengsel. Meer zand heeft geen bijkomend effect meer. De toename van de zandfractie zorgt voor een snellere consolidatie, kleinere laagdiktes (Fig 4.18) en hogere densiteiten. Ook deze effecten zijn beperkt tot een zekere maximale zandfractie. Er is een duidelijk verschil te merken tussen de twee 
gebruikte types Scheldeslib. De laagjes met slib 2 zijn gemiddeld 2 à $3 \mathrm{~cm}$ dik, de laagjes met slib 3 slechts ongeveer $1.5 \mathrm{~cm}$. Slib 3 heeft een hoger natuurlijk zandgehalte dan slib 2.

Wanneer men de densiteitsprofielen bekijkt, die geregistreerd zijn met de gamma-densimeter, kan de gelaagde structuur ook duidelijk worden waargenomen (Fig 4.19 en 4.20). De densiteitspieken worden veroorzaakt door de gesegregeerde zandlagen en geven het scheidingsoppervlak tussen de verschillende lagen aan. Ook hier zijn weer duidelijke verschillen tussen de twee slibsoorten merkbaar. Voor slib 3 verloopt de densiteit in ieder laagje zeer geleidelijk. Vermoedelijk wijst dit erop dat ook het zandgehalte min of meer lineair varieert over een laagje. Bij slib 2 daarentegen is een duidelijke piek met daarboven een meer uniforme zone merkbaar. De segregatie en de zandgehalteverschillen zijn hier veel duidelijker aanwezig. De maximale densiteiten in de mengsels met slib 3, met het hoogste zandgehalte, zijn merkelijk hoger $\left( \pm 1140 \mathrm{~kg} / \mathrm{m}^{3}\right)$ dan deze in de slib 2 mengsels $\left( \pm 1090 \mathrm{~kg} / \mathrm{m}^{3}\right)$. Voor één en hetzelfde slib is de relatie tussen densiteit en zandgehalte minder eenduidig (Fig 4.21). Het aantal experimenten is echter te beperkt om algemene besluiten te trekken.

De erosie van een gelaagd bed verschilt totaal van het hoger beschreven erosiegedrag van de homogene mengsels. Deze verschillen zijn niet alleen het gevolg van de opbouw van de bodem maar ook van de lagere densiteit. Het erosieproces start met het in suspensie gaan van het sliblaagje (Fig 4.22). De erosie neemt bij constant debiet en dus constante bodemschuifspanning geleidelijk af wegens de toenemende densiteit van het bed; de toenemende densiteit resulteert immers in een toenemende erosieweerstand. Verhoogt men het debiet dan zal de erosie weer starten. Een andere reden voor de geleidelijk afname van de verschillen in opgemeten concentraties op- en afwaarts van de meetsectie, is dat een zandlaagje bereikt wordt. Het zand zal immers, mits een voldoende bodemschuifspanning, in eerste instantie als bodemtransport bewegen. Men merkt dan ook dat wanneer het opgemeten bodemtransport toeneemt het suspensietransport afneemt en omgekeerd. De erosie van een gelaagde bodem is dus een continue afwisseling van zwevend en bodemtransport. De relatieve belangrijkheid van beide fasen is afhankelijk van de samenstelling van de bodem. In tegenstelling tot de homogene mengsels waar de erosiesnelheid een constante is, enkel afhankelijk van de bodemschuifspanning, varieert de erosiesnelheid van een gelaagd slib/zand bed voortdurend. 


\section{De invloed van de vorm en de afmetingen van de dwarsdoorsnede op de berekening van schuifspanningen}

In het kader van het F.K.F.O.-project werden gelijkaardige erosieproeven met homogene mengsels uitgevoerd in een kanaal met een half-cirkelvormige dwarsdoorsnede in het Laboratorium voor Hydraulica van de Universiteit Gent. De vergelijking van de proefresultaten toont aan dat de opgemeten erosiesnelheden bij dezelfde bodemschuifspanning (berekend met de wandcorrectie methode, side wall elimination technique, Appendix 1) en voor dezelfde mengselsamenstelling, in de cirkelvormige goot een grootteorde hoger liggen. Dit toont duidelijk de invloed van de vorm van de dwarsdoorsnede aan. In het kader van ditzelfde project werden eveneens veldmetingen uitgevoerd in de Schelde nabij Temse en in de hoofdmoerriool van Brussel. Deze metingen demonstreren dat niet alleen de vorm maar ook de afmetingen van de dwarsdoorsnede belangrijk zijn.

De oorzaak van de opgemerkte verschillen zijn secundaire stromingen. Deze secundaire stromingen beïnvloeden op hun beurt de schuifspanningsverdeling over de dwarsdoorsnede. Secundaire stromingssnelheden zijn zeer moeilijk op te meten aangezien ze slechts enkele procenten van de longitudinale stroming voorstellen. Nauwkeurige registratie van deze snelheden toont aan dat bij de overgang van een rechthoekige naar een trapezoïdale doorsnede (vergelijkbaar met een halve cirkel met sedimentbed) een extra stromingscel nabij de wand gevormd wordt (Fig 5.2). Deze extra circulatie veroorzaakt bijkomende turbulentie en een zeer grillig verloop van de bodemschuifspanning met verscheidene lokale maxima en minima. Andere onderzoekers stelden vast dat ook de verhouding tussen de breedte van het kanaal en de waterhoogte (aspect ratio) een belangrijke rol speelt. De traditionele rekentechnieken die gebruikt worden om het effect van de wanden in te rekenen, geven een overschatting van de gemiddelde bodemschuifspanning voor zeer nauwe kanalen.

Om de invloed van de vorm van de dwarsdoorsnede meer in detail te bestuderen, is een reeks extra experimenten uitgevoerd zowel in de rechthoekige als in de half-cirkelvormige goot, tijdens dewelke de snelheidsverdeling over de ganse sectie nauwkeurig is opgemeten. Uit iedere snelheidsverticaal kan immers de lokale bodemschuifspanning worden afgeleid. Een 
sensitiviteitsanalyse van deze berekeningsmethode leert dat de resultaten zeer gevoelig zijn aan fouten in het referentieniveau, m.a.w. het niveau waarop de snelheid gelijk is aan nul (tabel 3.2). Vooral wanneer men te maken heeft met een ruwe bodem of bedvormen, is de bepaling van het referentieniveau moeilijk. De berekening van een globale bodemschuifspanning m.b.v. een wandcorrectiemethode is minder gevoelig aan onzekerheden in verband met de bodemligging. Deze berekeningen verschaffen echter geen enkele informatie over het verloop van de schuifspanningen over de dwarsdoorsnede.

Voor de rechthoekige dwarsdoorsnede blijkt de verdeling van de bodemschuifspanningen vrij uniform. Meestal wordt slechts één maximum aangetroffen in het midden van de doorsnede. De schuifspanning berekend uit een centrale snelheidsverticaal geeft dus een goede benadering van de maximale bodemschuifspanning. Deze maximale waarde is belangrijk voor de bepaling van het begin van beweging. Voor de berekening van sedimenttransport en erosiesnelheden is echter de gemiddelde bodemschuifspanning nodig. Uit de gedetailleerde snelheidsmetingen blijkt deze ongeveer $70 \%$ van de maximale waarde te bedragen. De schuifspanning berekend met de wandcorrectiemethode is een overschatting van de gemiddelde waarde en stemt algemeen beter overeen met de maximale waarde.

In de half-cirkelvormige doorsnede verloopt de bodemschuifspanning een stuk grilliger. De maximale waarde bevindt zich meestal net excentrisch en een bijkomend belangrijk maximum in de verdeling wordt aangetroffen dicht bij de wand. Dit verklaart de sterke erosie die daar werd geobserveerd. De centrale waarde geeft een goede indicatie voor de gemiddelde waarde, die op haar beurt ongeveer $75 \%$ van de maximale waarde bedraagt. De wandcorrectie methode geeft ook hier een duidelijke overschatting van de gemiddelde waarde. De hogere gemiddelde schuifspanning voor eenzelfde berekende maximale schuifspanning samen met de sterke secundaire stromingen, veroorzaken de hogere erosiesnelheden in de half-cirkelvormige goot. 


\section{Modelléren van het erosiegedrag van slib/zand mengsels}

\section{Erosieweerstand}

Wanneer men de erosieweerstand van de homogene mengsels uitzet in functie van het gehalte fijne deeltjes krijgt men een op het eerste zicht lineaire curve, die bij nader inzien een verloop vertoont zoals schematisch voorgesteld in Figuur 6.1. De variatie in kritische schuifspanning kan verklaard worden aan de hand van de veranderingen in de inwendige structuur van het mengsel. Om deze wijzigingen visueel voor te stellen wordt een aantal kaolinietmengsels gemaakt met een percentage fijn materiaal variërend tussen $5 \%$ en $20 \%$. Van deze mengsels worden opnames gemaakt met een scanning elektronenmikroskoop (foto's 3 t.e.m. 7). Het nadeel aan deze techniek is dat de monsters volledig droog moeten zijn; het drogen van de stalen zal immers een invloed hebben op de uiteindelijke structuur. Deze invloed wordt geminimaliseerd door de monsters zeer langzaam aan de lucht te drogen. Tijdens het drogen zullen ongebonden kleivlokken neerslaan op de zandkorrels (foto's 4 en 6). Wanneer het droogproces wordt versneld zal ook de structuur van de kleiplaatjes ineenklappen: foto 7 (gedroogd op $105^{\circ} \mathrm{C}$ ) toont een redelijke parallelle oriëntatie van de kleiplaatjes t.o.v. foto 6 (gedroogd op kamertemperatuur) waar een kaarthuisstructuur zichtbaar is.

De evolutie van de erosieweerstand kan nu als volgt verklaard worden (foto's 3a t.e.m. 3e en foto's $4 \mathrm{a}$ t.e.m. 4d). Wanneer slechts een kleine hoeveelheid fijne deeltjes in het mengsel aanwezig is, zullen deze bij een laag debiet uit de oppervlaktelaag worden uitgespoeld. De kritische schuifspanning zal dus lager zijn dan voor zand alleen, maar hoger dan verwacht voor een uniforme bodem van fijne deeltjes zonder cohesie. De kleine deeltjes zitten immers verstopt achter de zandkorrels en zijn daardoor moeilijker bereikbaar door de stroming. Eventueel kan aan het oppervlak zelfs enige binding tussen de kleiplaatjes ontstaan.

Verhoogt men het percentage fijne deeltjes dan zullen deze stilaan de poriën tussen de zandkorrels opvullen. De bodem wordt veel gladder en dus moeilijker erodeerbaar. Tussen sommige zandkorrels ontstaat een soort van bruggen in kleivlokken die de korrels verbinden. In eerste instantie zijn deze bruggen dunne draden, die geen weerstand bieden. Geleidelijk worden 
heuse netwerken gevormd die het sedimentmengsel extra erosieweerstand verschaffen. De belangrijkste factor in de erosieweerstand van deze mengsels blijft echter de korrelwrijving. Vanaf een bepaald percentage cohesief materiaal in het mengsel zijn de zandkorrels volledig omgeven door cohesieve deeltjes die een structuur vormen. De zandkorrels raken elkaar niet meer en de erosieweerstand wordt nu volledig bepaald door de cohesieve fractie. Het kritische percentage ligt voor alle geteste mengsels tussen $5 \%$ en $15 \%$ fijn materiaal (gewichtsfractie). Boven deze grens gedraagt het mengsel zich als een cohesief materiaal, niet alleen wat betreft de erosieweerstand maar ook wat betreft de erosiesnelheden en de bedvormen.

Het is echter zinvoller om met volumefracties te rekenen aangezien het kritische gehalte te maken heeft met het volume dat nodig is om tussen de zandkorrels een netwerkstructuur te vormen. Deze kritische volumefractie van fijne deeltjes op het totaal volume van sediment en water is ongeveer $5 \%$. Dit komt overeen met het gelpunt van zuiver cohesief materiaal. Wanneer het cohesief materiaal in het zandskelet een structuur vormt, kan men dus spreken van een overwegend cohesief materiaal. Als men aanneemt dat het zand een porositeit heeft van 40 tot $45 \%$ en het watergehalte in de mengsels met densiteit $1850 \mathrm{~kg} / \mathrm{m}^{3}$ steeds ongeveer $35 \%$ is, vindt men weerom een volumefractie van ongeveer $5 \%$ nodig om de poriën van het zand volledig te vullen. Deze grens stemt overeen met de waarden die door verscheidene andere onderzoekers werden vooropgesteld.

Uitgaande van de krachtswerking op het sedimentbed wordt een algemene uitdrukking voor de kritische schuifspanning afgeleid (vgl 6.4). Deze vergelijking omvat zowel de invloed van hefkracht, sleepkracht en graviteit als de effecten van cohesie en adhesie. De formule bevat een groot aantal onbekende constanten en coëfficiënten die moeten bepaald worden. Voor mengsels moeten daarbij nog de interacties tussen de verschillende fracties ingerekend worden. Daarbij wordt uitgegaan van bestaande theorieën voor heterogene niet-cohesieve sedimenten met kleinere korrels die beschermd worden door de grotere. Voor cohesieve mengsels wordt de interactie verder ingerekend in de wrijvingshoek $\phi$, die varieert met de samenstelling van het mengsel. Ondanks de beperkingen van de formule en de vele veronderstellingen die nodig zijn om een waarde te geven aan de verschillende constanten is de formule toch in staat een goede benadering voor de experimentele waarden te verschaffen. De overgang van niet-cohesieve naar cohesieve mengsels zit vervat in de verhouding van de adhesiekrachten tot de gravitaire krachten. Is deze 
verhouding veel kleiner dan 1, dan overheerst het gewicht en heeft men te doen met een nietcohesief mengsel. Nadert deze verhouding 1 dan worden de cohesie en adhesie stilaan belangrijker en eens deze verhouding veel groter wordt dan 1 heeft men te doen met een cohesief mengsel waarin het eigengewicht een verwaarloosbare rol speelt in de erosieweerstand.

Natuurlijk kan ook nu weer het stochastisch aspect van het erosieproces in rekening gebracht worden. Men moet dan niet alleen rekening houden met de turbulente variaties van de snelheid doch ook de eigenschappen van het bodemmateriaal zijn stochastische parameters die variëren zowel in de tijd, omwille van consolidatieprocessen en biologische reacties, als in de ruimte, omwille van de variabele mengselkarakteristieken over het bed.

\section{Modelleren van de erosie}

Uit het experimenteel onderzoek en uit de fysische verklaringen die werden gevonden voor de interne structuur die zich vormt in het slib/zand bed, blijkt dat, afhankelijk van de mengselsamenstelling, een slib/zand mengsel kan beschouwd worden als een niet-cohesief of een cohesief materiaal. Het lijkt dan ook niet nodig een specifiek erosiemodel voor mengsels te ontwikkelen. De bestaande erosie- en transportmodellen voor zowel zand als voor cohesief sediment blijken immers in staat de opgemeten erosiesnelheden, zwevend en bodemtransport van de mengsels te voorspellen. Enkel bij de bepaling van de erosieweerstand dient rekening te worden gehouden met het specifieke mengselkarakter van het bed.

Een erosie- en transportmodel kan dan ook worden opgebouwd met behulp van bestaande modules mits een aantal stappen worden toegevoegd (Fig 6.7). Eerst en vooral moet de samenstelling en densiteit van de oppervlaktelaag geanalyseerd worden. Afhankelijk van de densiteit, het gehalte aan klei en fijne deeltjes en de korrelgrootte en porositeit van het zand kan men dan uitmaken of het gaat om een niet-cohesief dan wel een cohesief mengsel. Voor de cohesieve mengsels kan men verder nagaan of er vermoedelijk massa-erosie of oppervlakteerosie zal optreden. Nadien kan men aan de hand van vergelijking (6.4) of aan de hand van meetgegevens de erosieweerstand van de oppervlaktelaag bepalen. Vervolgens kan men met behulp van een hydrodynamisch model de bodemschuifspanning berekenen. Eventueel kan daarbij rekening gehouden worden met schaal- en vormeffecten. Wanneer de 
bodemschuifspanning groter is dan de kritische waarde zal erosie optreden en kunnen sedimenttransport en/of erosiesnelheid berekend worden met bestaande transportformules. Als de eigenschappen van de bodem variëren over de diepte, moet bij iedere tijdstap de dikte van de geërodeerde laag worden bijgehouden. Deze kan berekend worden uit de erosiesnelheid en het densiteitsprofiel. Vervolgens kan men de nieuwe eigenschappen van de oppervlaktelaag evalueren en de berekeningen hervatten.

Een dergelijk model om de erosie van een slib/zand bed te voorspellen, veronderstelt een goede kennis van zowel stromingskarakterisiteken als van de bodemeigenschappen. Wat de stroming betreft, is het vooral de bodemschuifspanning die een belangrijke rol speelt. Deze wordt op haar beurt sterk beïnvloed door de geometrie. De nauwkeurigheid van de transportberekeningen is immers zeer sterk afhankelijk van de nauwkeurigheid waarmee de schuifspanningen worden berekend. Voor de karakterisatie van het bodemmateriaal zijn vooral samenstelling en densiteitsprofiel van belang. Het densiteitsprofiel kan eventueel berekend worden met behulp van een sedimentatie-consolidatie model. Zulk een model geeft echter geen uitsluitsel over de mengselsamenstelling. Om deze samenstelling te bepalen zijn er monsters nodig, waarvan men op zijn minst de fractie kleiner dan $63 \mu \mathrm{m}$ bepaald. Verder hebben de kleifractie (kleiner dan $2 \mu \mathrm{m}$ ) en het organisch materiaal ook een invloed op het erosiegedrag. Uitgaande van de beschikbare gegevens in verband met het bodemmateriaal kan men dan een schatting maken van de constanten die in de verschillende erosie- en transportformules voorkomen. Indien echter meetgegevens beschikbaar zijn, wordt de keuze van de constanten een stuk eenvoudiger.

\section{Besluiten}

In dit proefschrift is aan de hand van laboratoriumexperimenten het erosiegedrag van slib/zand mengsels in uniforme stroming onderzocht. Afhankelijk van hun samenstelling, d.w.z. het gehalte aan cohesief materiaal of de zandfractie, kunnen de mengsels opgedeeld worden in cohesief of niet-cohesief, zowel qua erosieweerstand als qua erosiemechanismen. Wanneer de volumefractie van de fijne deeltjes groter wordt dan $5 \%$, wordt er in het mengsel een cohesieve netwerkstructuur gevormd die zandkorrels volledig omgeeft. De zandkorrels verliezen het contact met elkaar en het mengsel gedraagt zich als een zuiver cohesief materiaal. De erosieweerstand 
neemt geleidelijk toe met toenemende kleifractie. De densiteit van het bed, het type cohesief materiaal, de consolidatieduur en de aanwezigheid van organisch materiaal, zijn eveneens factoren die de erosie sterk beïnvloeden.

Wanneer de bodem gevormd wordt door bezinking van een slib/zand suspensie, ontstaat een gelaagd sedimentbed bestaande uit zand en slib laminaten. De erosie van zulke gelaagde bodems is een opeenvolging van zwevend transport- en bodemtransportfases.

Verder is het effect van de vorm en afmetingen van de dwarsdoorsnede op de berekening van bodemschuifspanningen aangetoond. Aangezien de bodemschuifspanning één van de belangrijkste parameters is die het erosieproces controleert, moet met deze effecten terdege rekening gehouden worden, wanneer men de resultaten van laboratoriumonderzoek wil extrapoleren naar de realiteit.

Tenslotte zijn een aantal richtlijnen geformuleerd met betrekking tot het modelleren van de erosie van een slib/zand bodem. Uitgaande van de krachtswerkingen op het bed is een vergelijking opgesteld waarmee de erosieweerstand van een slib/zand mengsel kan berekend worden. Het voorspellen van sedimenttransport en erosiesneldheden kan gebeuren door toepassing van bestaande transportformules voor cohesief of niet-cohesief materiaal indien de samenstelling van het mengsel gekend is. Een goede kennis van de stromingskarakteristieken en de sedimenteigenschappen is daarbij onontbeerlijk. Indien de bodemopbouw niet homogeen is, moeten ook het densiteitsprofiel en de variatie van de mengselssamenstelling gekend zijn of berekend worden. 


\section{Table of contents}

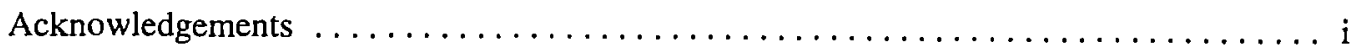

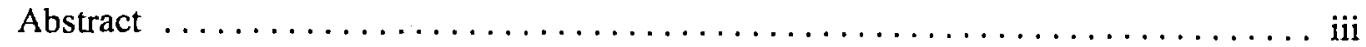

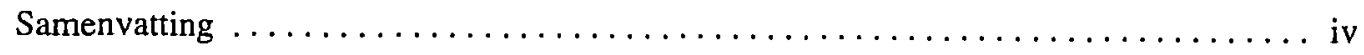

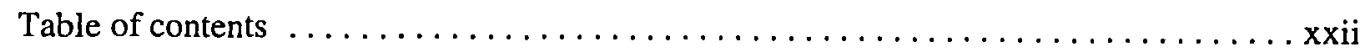

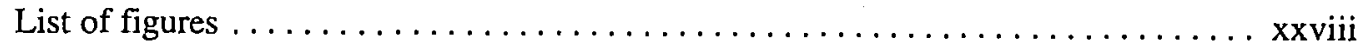

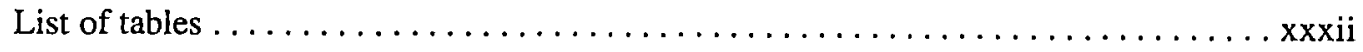

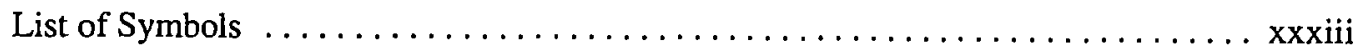

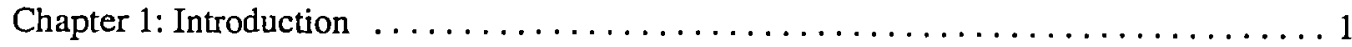

1.1 Why study the erosion of mud/sand mixtures $? \ldots \ldots \ldots \ldots \ldots \ldots \ldots 1$

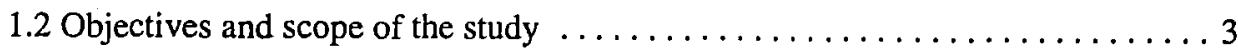

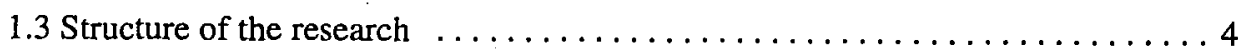

Chapter 2: Erosion and sediment transport in uniform flow $\ldots \ldots \ldots \ldots \ldots \ldots \ldots 6$

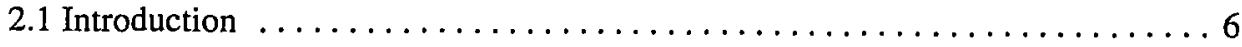

2.2 Cohesionless sediments $\ldots \ldots \ldots \ldots \ldots \ldots \ldots \ldots \ldots \ldots \ldots \ldots, 7$

2.2.1 Incipient motion $\ldots \ldots \ldots \ldots \ldots \ldots \ldots \ldots \ldots \ldots \ldots, \ldots \ldots \ldots$

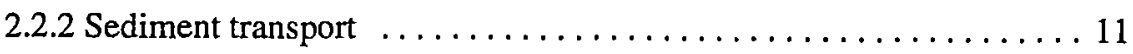

A. Ackers and White (Ackers 1991) $\ldots \ldots \ldots \ldots \ldots \ldots \ldots 12$

B. van Rijn (van Rijn 1989) . . . . . . . . . . . . . . . 12

C. Einstein's bed load equation (Einstein 1982, Berlamont 1981) $\quad$.. 13 
D. Calculation of flow resistance $\ldots \ldots \ldots \ldots \ldots \ldots \ldots$

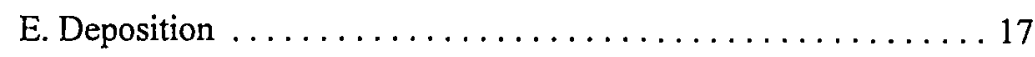

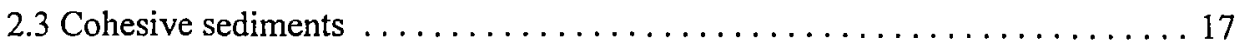

2.3.1 Nature of cohesive sediments $\ldots \ldots \ldots \ldots \ldots \ldots \ldots \ldots \ldots \ldots$

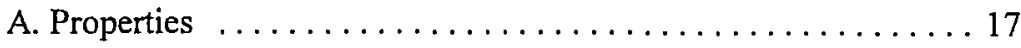

B. Characteristics of the sediment bed $\ldots \ldots \ldots \ldots \ldots \ldots \ldots$

Settling and consolidation $\ldots \ldots \ldots \ldots \ldots \ldots \ldots \ldots \ldots$

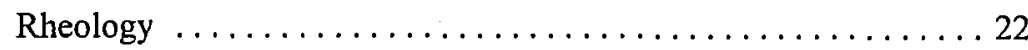

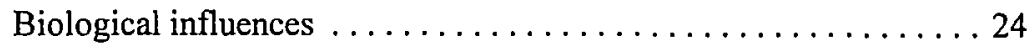

2.3.2 Erosional behaviour of cohesive sediments $\ldots \ldots \ldots \ldots \ldots \ldots 25$

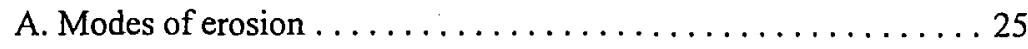

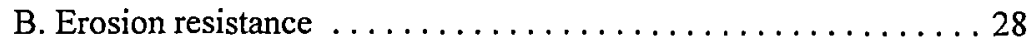

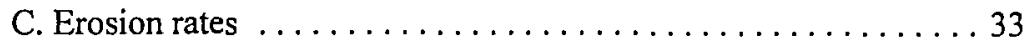

2.4 Mixed cohesive/non cohesive sediments $\ldots \ldots \ldots \ldots \ldots \ldots \ldots \ldots \ldots \ldots \ldots \ldots \ldots \ldots$

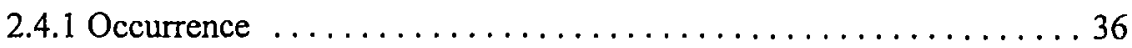

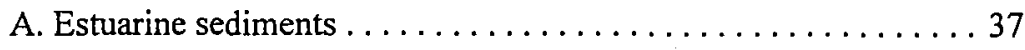

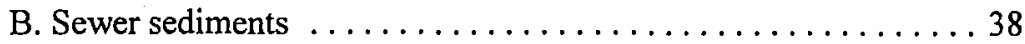

2.4.2 Erosion of mixed sediments $\ldots \ldots \ldots \ldots \ldots \ldots \ldots \ldots \ldots \ldots$

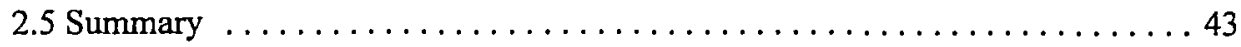

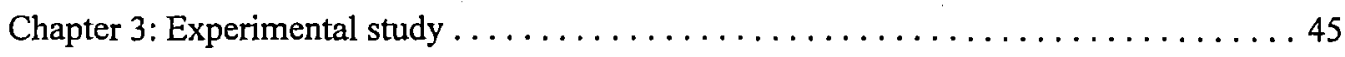

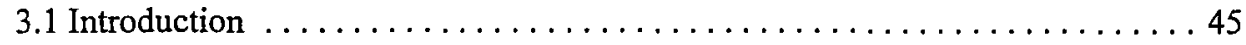

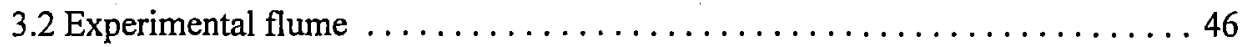

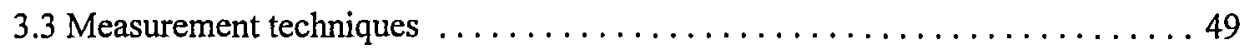

3.3.1 Water level $\ldots \ldots \ldots \ldots \ldots \ldots \ldots \ldots \ldots \ldots \ldots \ldots \ldots \ldots$

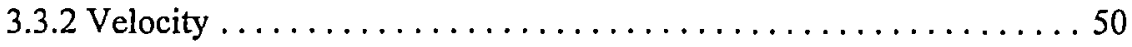

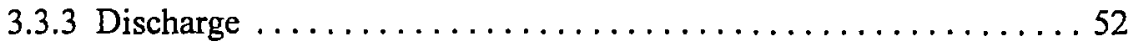

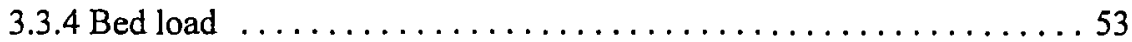

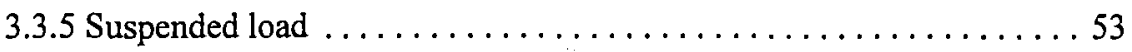

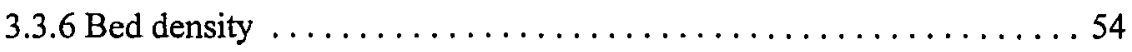

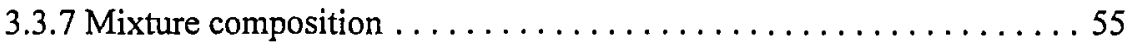

xxiii 


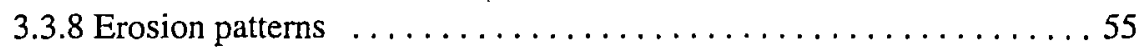

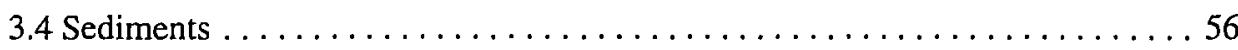

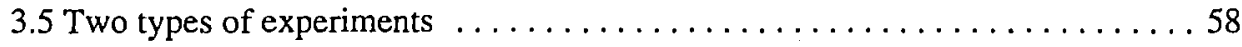

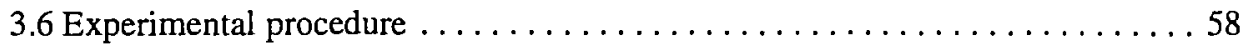

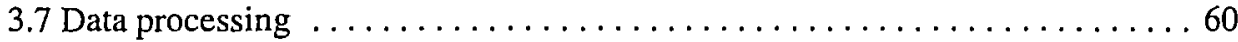

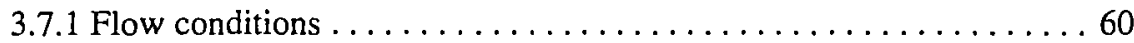

3.7.2 Erosion and sediment transport $\ldots \ldots \ldots \ldots \ldots \ldots \ldots \ldots \ldots \ldots$

3.7.3 Bed shear stress . . . . . . . . . . . . . . . . . 62

A. Velocity profile $\ldots \ldots \ldots \ldots \ldots \ldots \ldots \ldots \ldots \ldots \ldots \ldots \ldots \ldots \ldots \ldots \ldots \ldots$

B. Side wall elimination technique $\ldots \ldots \ldots \ldots \ldots \ldots \ldots \ldots 6$

C. Sensitivity of the bed shear stress calculations $\ldots \ldots \ldots \ldots 64$

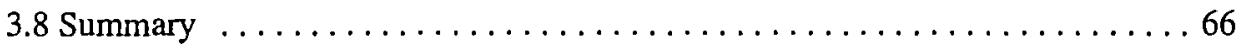

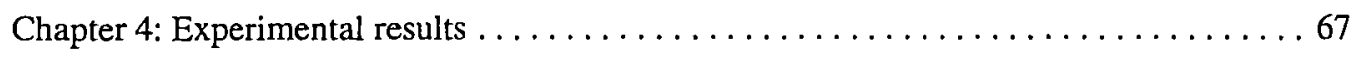

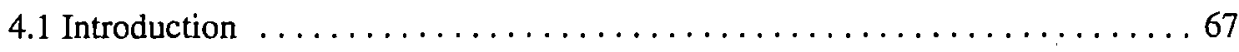

4.2 Preliminary experiments on the erosion of sand $\ldots \ldots \ldots \ldots \ldots \ldots \ldots$

4.2.1 Aim of the preliminary experiments $\ldots \ldots \ldots \ldots \ldots \ldots \ldots \ldots$

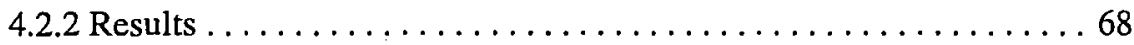

A. Critical shear stress for erosion $\ldots \ldots \ldots \ldots \ldots \ldots \ldots \ldots$

B. Sediment transport rates $\ldots \ldots \ldots \ldots \ldots \ldots \ldots \ldots \ldots$

C. Comparison with existing transport formulas $\ldots \ldots \ldots \ldots \ldots 71$

4.3 Erosion of homogeneous mixtures $\ldots \ldots \ldots \ldots \ldots \ldots \ldots \ldots \ldots \ldots \ldots$

4.3.1 Aim of the experiments $\ldots \ldots \ldots \ldots \ldots \ldots \ldots \ldots \ldots \ldots \ldots$

4.3.2 Description of the observed erosion processes $\ldots \ldots \ldots \ldots \ldots \ldots 74$

4.3.3 Measured erosion resistance $\ldots \ldots \ldots \ldots \ldots \ldots \ldots \ldots \ldots \ldots$

4.3.4 Measured sediment transport and erosion rates $\ldots \ldots \ldots \ldots \ldots 84$

A. Cohesionless mixtures $\ldots \ldots \ldots \ldots \ldots \ldots \ldots \ldots \ldots \ldots$

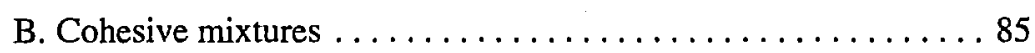

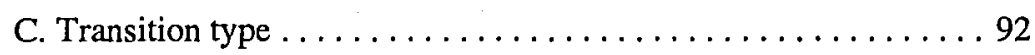

4.4 Erosion of deposited mixtures $\ldots \ldots \ldots \ldots \ldots \ldots \ldots \ldots \ldots \ldots \ldots \ldots$

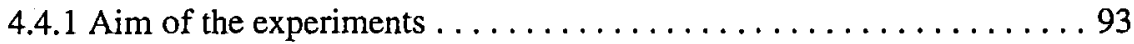




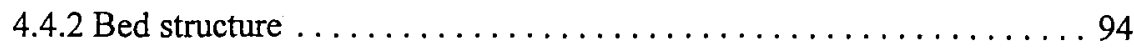

A. Settling and consolidation of mud/sand mixtures ....... 95

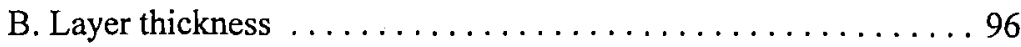

C. Density profiles $\ldots \ldots \ldots \ldots \ldots \ldots \ldots \ldots \ldots \ldots \ldots$

4.4.3 Description of the observed erosion process . . . . . . . . 101

4.4.4 Erosion resistance and measured erosion rates $\ldots \ldots \ldots \ldots \ldots$

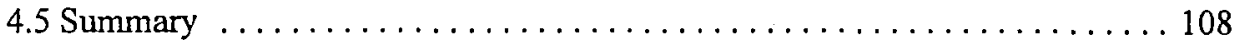

4.5.1 Influence of mixture composition $\ldots \ldots \ldots \ldots \ldots \ldots \ldots \ldots$

A. Amount of cohesive material in the mixture . . . . . . . . 109

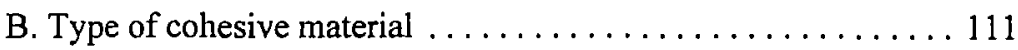

4.5.2 Influence of bed density and consolidation time $\ldots \ldots \ldots \ldots 112$

4.5.3 Influence of bed formation $\ldots \ldots \ldots \ldots \ldots \ldots \ldots \ldots \ldots \ldots$

Chapter 5: The influence of the shape and scale of the flume cross section on bed shear stress

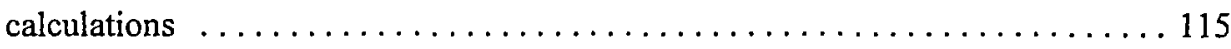

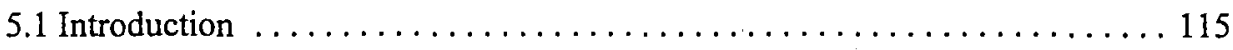

5.2 Literature review on the relation between secondary currents and shear stress

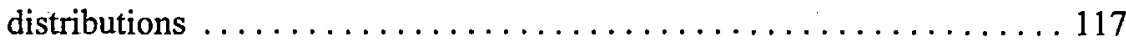

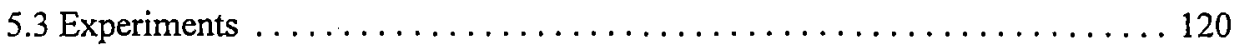

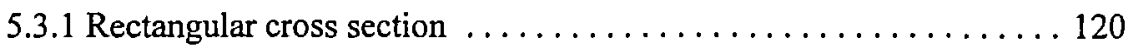

5.3.2 Comparison between the side wall correction method and the law of the

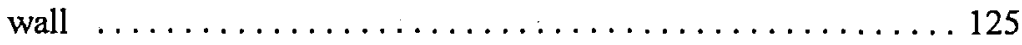

5.3.3 Comparison with a circular cross section $\ldots \ldots \ldots \ldots \ldots \ldots \ldots 127$

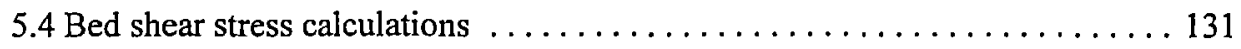

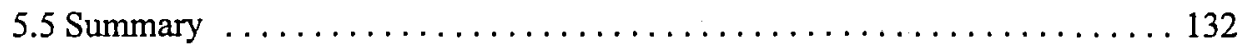

Chapter 6: Modelling the erosion of mud/sand mixtures $\ldots \ldots \ldots \ldots \ldots \ldots \ldots \ldots$

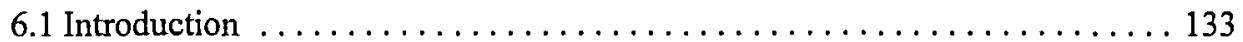

6.2 Modelling the erosion resistance of $\mathrm{mud} / \mathrm{sand}$ mixtures $\ldots \ldots \ldots \ldots \ldots 134$

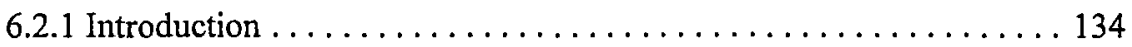

6.2.2 Erosion resistance as a function of mixture composition . . . . . . 134 
6.2.3 Prediction of the critical shear stress for erosion $\ldots \ldots \ldots \ldots \ldots 139$

A. Incipient motion criterion for uniform sediment . . . . . 140

B. Sediment mixtures $\ldots \ldots \ldots \ldots \ldots \ldots \ldots \ldots \ldots \ldots \ldots \ldots$

Cohesionless sediments $\ldots \ldots \ldots \ldots \ldots \ldots \ldots \ldots \ldots \ldots 143$

Cohesive sediments $\ldots \ldots \ldots \ldots \ldots \ldots \ldots \ldots \ldots \ldots \ldots \ldots$

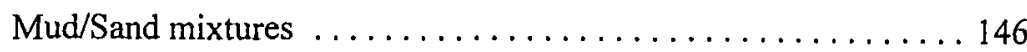

C. Comparison with measured data $\ldots \ldots \ldots \ldots \ldots \ldots \ldots$

Cohesionless mixtures $\ldots \ldots \ldots \ldots \ldots \ldots \ldots \ldots \ldots \ldots \ldots$

Cohesive mixtures $\ldots \ldots \ldots \ldots \ldots \ldots \ldots \ldots \ldots \ldots \ldots \ldots \ldots$

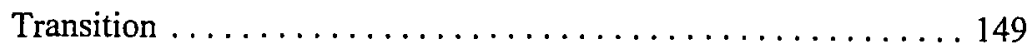

D. The probability for erosion $\ldots \ldots \ldots \ldots \ldots \ldots \ldots \ldots \ldots$

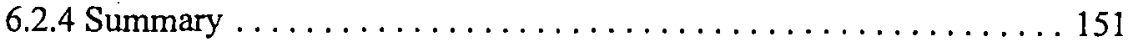

6.3 Modelling erosion rates of $\mathrm{mud} /$ sand mixtures $\ldots \ldots \ldots \ldots \ldots \ldots \ldots \ldots$

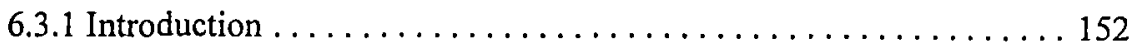

6.3.2 Predicting erosion rates and sediment transport $\ldots \ldots \ldots \ldots \ldots 153$

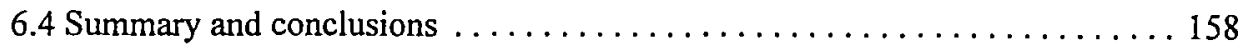

6.4.1 Necessary information to model the erosion of mud/sand mixtures . . 158

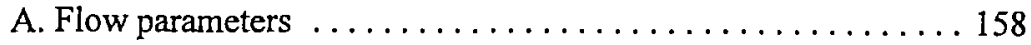

B. Sediment properties . .................. 159

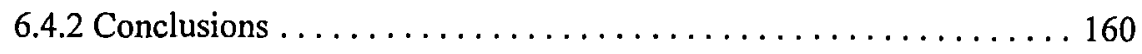

Chapter $7:$ Conclusions and recommendations $\ldots \ldots \ldots \ldots \ldots \ldots \ldots \ldots \ldots \ldots \ldots \ldots$

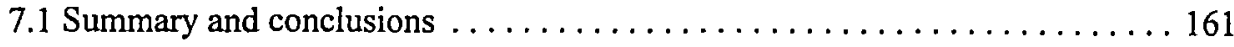

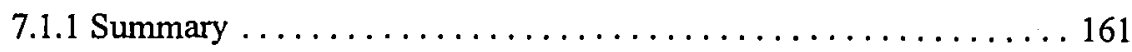

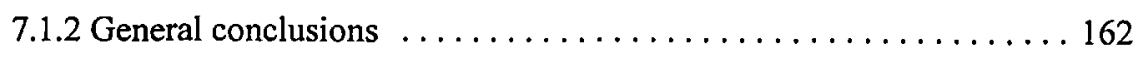

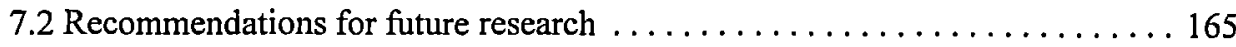

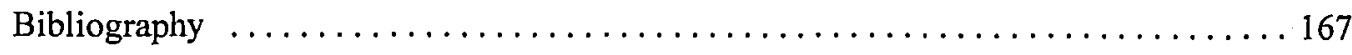

Plates 
Appendix 1: Calculation of the bed shear stress using a side wall elimination technique .194

Appendix 2: Accuracy of the experimental data $\ldots \ldots \ldots \ldots \ldots \ldots \ldots \ldots \ldots$

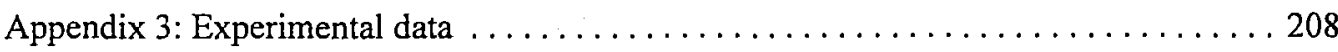

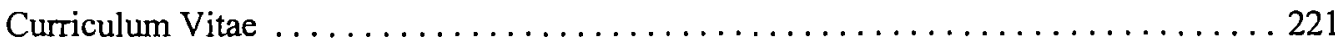

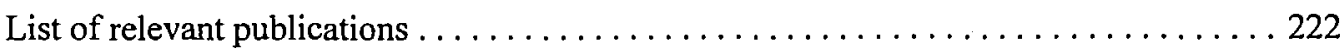




\section{List of figures}

Figure 2.1: Forces acting on a grain at incipient motion. $\ldots \ldots \ldots \ldots \ldots \ldots \ldots$

Figure 2.2: Shields diagram (Berlamont 1981, Yalin et al 1979). . . . . . . . 8

Figure 2.3: Stratified cohesive sediment bed (Mehta et al. 1990). . . . . . . . . . . 21

Figure 2.4: Different rheological models for low concentration suspensions.

1. Power law or Pseudo-plastic model; 2. Bingham model ......... 23

Figure 2.5: Coulomb's law for soil failure, $C$ is the cohesion, $\sigma^{\prime}$ is the effective stress and $\phi$ is the angle of internal friction. . . . . . . . . . . . . . . . 24

Figure 2.6: Different modes of cohesive sediment erosion (Mehta 1991).

a. Surface erosion. b. Mass erosion. c. Re-entrainment of fluid mud. . . . . 26

Figure 3.1: Side view of the rectangular flume. $\ldots \ldots \ldots \ldots \ldots \ldots \ldots \ldots \ldots$

Figure 3.2: Calibration of the two static pressure transducers (water level upstream and downstream) and the differential pressure transducer (flow velocity). . . . . 49

Figure 3.3: Comparison between velocities measured by the micro propeller (MP) and the

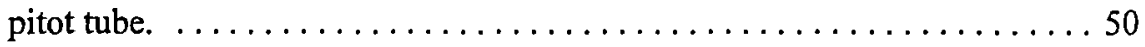

Figure 3.4: Velocity profiles measured at different positions along the length of the flume.

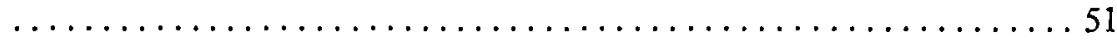

Figure 3.5: Comparison between a velocity profile measured above the fixed bed $(x=3.3 \mathrm{~m})$ and a profile measured above a sand bed $(x=4.3 \mathrm{~m}) \ldots \ldots \ldots 52$

Figure 3.6: Measured concentration profile above a montmorillonite mixture. . . . . 54

Figure 3.7: Grain size distribution of the used sediments. The grain size distribution of the sand is established by sieve analysis. For the cohesive sediments, the grain sizes are determined by measuring the settling velocity of the sediment in a small

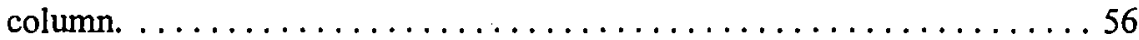

Figure 4.1: Experimental determination of the critical mobility number for sand. . . . 69

Figure 4.2: Comparison between measured values and bed load predicted using

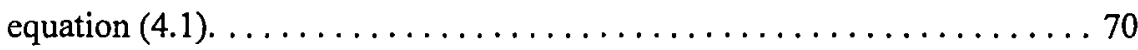

Figure 4.3: Comparison with the Ackers and White total load formula. $\ldots \ldots \ldots \ldots 7$ 
Figure 4.4: Comparison with the van Rijn bed load equation. ............ 71

Figure 4.5: Comparison with Einstein's bed load function. $\ldots \ldots \ldots \ldots \ldots \ldots \ldots 72$

Figure 4.6: Measured critical shear stresses for the montmorillonite mixtures. . . . . . 77

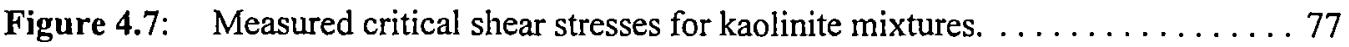

Figure 4.8: $\quad$ Measured critical shear stresses for mud mixtures. $\ldots \ldots \ldots \ldots \ldots \ldots 78$

Figure 4.9: Erosion rates as a function of bed shear stress for montmorillonite mixtures. 82

Figure 4.10: Erosion rates as a function of bed shear stress for kaolinite mixtures. . . . 83

Figure 4.11: Erosion rates as a function of bed shear stress for mudl mixtures. $\ldots \ldots 83$

Figure 4.12: Measured bed load transport rates for the cohesionless mixtures. . . . . 85

Figure 4.13: Comparison between measured erosion rates and surface erosion equation (2.43).

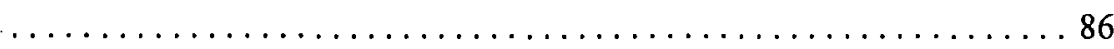

Figure 4.14: Measured erosion rates for the montmorillonite mixtures. . . . . . . . 89

Figure 4.15: Measured erosion rates for the kaolinite mixtures. . . . . . . . . 91

Figure 4.16: Measured erosion rates for the mud 1 mixtures. . . . . . . . . . . 91

Figure 4.17: The transition zone for the montmorillonite mixtures. . . . . . . . 92

Figure 4.18: Mean layer thickness as a function of sand content. . . . . . . . . 97

Figure 4.19: Density profile for experiment J5, mud2 mixture, sand content $29 \%$. . . . 98

Figure 4.20: Density profile for experiment J6, mud3 mixture, sand content $41 \%$. . . 98

Figure 4.21: Peak density of the bottom layer as a function of sand content. . . . . 101

Figure 4.22: Overview of a typical erosion experiment. . . . . . . . . . . 102

Figure 4.23; Modelling of the mud erosion rates for experiment J6. . . . . . . 106

Figure 4.24: Measured bed load transport in the layered bed experiments, compared with

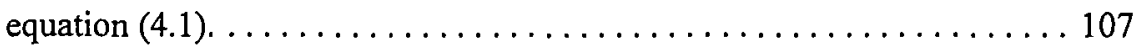

Figure 4.25: Erosion of a homogeneous mud2 mixture. . . . . . . . . . . 113

Figure 4.26: Erosion of a layered mud 2 mixture. . . . . . . . . . . . . 114

Figure 5.1: Comparison of measured erosion rates for kaolinite mixtures. . . . . . 116

Figure 5.2: Secondary flow structure in different cross section (Tominaga et al. 1989). 118

Figure 5.3: Classification of possible bed shear stress distributions in a circular cross section (Kleijwegt 1992). ............................. 119

Figure 5.4: Measured velocity profiles for an experiment with a smooth sand/kaolinite bed. The legend gives the distance from the centre in centimetres. . . . . . 121 
Figure 5.5: Measured velocity profiles for experiment on a rougher sand bed. The legend gives the distance from the centre in centimetres.

Figure 5.6: Example of a velocity profile, registered during a sediment transport measuringcampaign on the river Scheldt at Temse (Kabir et al. 1991) . . . . . . 122

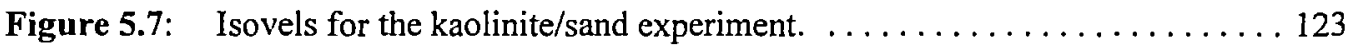

Figure 5.8: Bed shear stresses along the cross section, calculated from the velocity distributions, for the kaolinite mixture experiment. . . . . . . . . . 124

Figure 5.9: Maximum versus centre line bed shear stress, calculated from the velocity profiles.

Figure 5.10: Comparison between side wall elimination and the maximum bed shear stress.

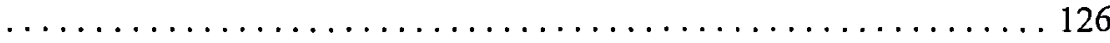

Figure 5.11: Maximum versus mean bed shear stress, both calculated from the measured

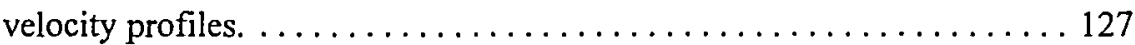

Figure 5.12: Measured velocity distributions for the semi-circular flume. $\ldots \ldots \ldots \ldots 128$

Figure 5.13: Shear stress distributions measured for the semi-circular cross section for different values of the flow rate. In abscissa the distance from the centre is given. . . 128

Figure 5.14: Cross section of the Brussels trunk sewer. . . . . . . . . . . . 130

Figure 5.15: Measured iso-velocity lines for the Brussels collector. Left hand side: measurements at 4 a.m., the discharge is $0.608 \mathrm{~m}^{3} / \mathrm{s}$ and the centre line water depth is $63 \mathrm{~cm}$. Right hand side: measurements at 12 a.m., the discharge is $1.522 \mathrm{~m}^{3} / \mathrm{s}$ and the centre line water depth is $108 \mathrm{~cm} . \ldots \ldots \ldots \ldots 130$

Figure 6.1: Erosion resistance of $\mathrm{mud} / \mathrm{sand}$ mixtures as a function of the amount of fines.

Figure 6.2: Forces acting on a sediment grain at the surface of a bed at incipient motion

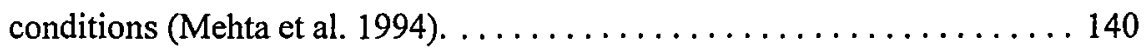

Figure 6.3: Variation of the different factors affecting the force balance: friction angle $(\phi)$, grain projection (p) above the mean local bed level and grain exposure (e) above the local upstream surface (Kirchner et al. 1990).

Figure 6.4: Calculated critical shear stresses as a function of the wall Reynolds number (R.)

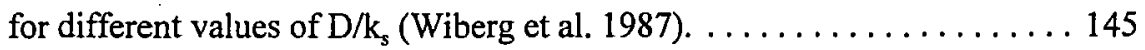

Figure 6.5: Measured friction angle versus clay content (Amos et al. 1994) . . . . . . 146 
Figure 6.6: Calculated critical shear stress as a function of the relative magnitude of the

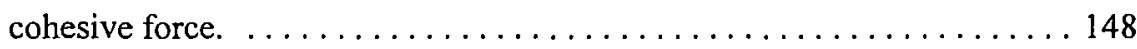

Figure 6.7: Structure of a general model to predict the erosion of mud/sand mixtures. . 154

Figure A1.1: Division of the wetted area into wall- and bed-related regions. . . . . . 195

Figure A2.1: Output signal of the pressure transducer. $\ldots \ldots \ldots \ldots \ldots \ldots \ldots \ldots$

Figure A2.2: Output signal of the electromagnetic flow-meter. $\ldots \ldots \ldots \ldots \ldots \ldots 201$

Figure A2.3: Output signal of the differential pressure transducer. . . . . . . . . 202

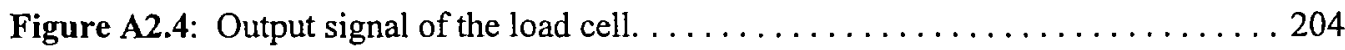




\section{List of tables}

Table 2.1: Physical characteristics of sewer sediment types (Williams et al. 1989). . . . 39

Table 3.1: Composition of the sediment mixtures. . . . . . . . . . . . . 57

Table 3.2: Sensitivity analysis for the two different methods for the calculation of bed shear

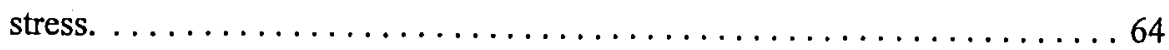

Table 4.1: Examples of critical shear stresses $\left(\tau_{\mathrm{cr}}\right)$ for the erosion of dense cohesive sediments and mixtures $\left(\rho_{b}\right.$ is the bulk density of the sediments) $\ldots \ldots \ldots \ldots \ldots$

Table 4.2: Experimental coefficients for surface erosion (equation (2.43)). . . . . . 86

Table 4.3: Coefficients for surface erosion (equation (2.43)), from Mehta (1988) . . . 87

Table 4.4: Coefficients for equation (2.44) for surface erosion from (Mehta 1988). . . . 88

Table 4.5: Coefficients for equation (4.4) $\ldots \ldots \ldots \ldots \ldots \ldots \ldots \ldots \ldots \ldots$

Table 4.6: Input conditions for the layered bed formation process. $\ldots \ldots \ldots \ldots \ldots . .94$

Table 4.7: Overview of the coefficients used for modelling the erosion rates. . . . . . 105 


\section{List of Symbols}

\begin{tabular}{|c|c|c|}
\hline \multirow[t]{2}{*}{ a } & {$[-]$} & coefficient \\
\hline & {$[\mathrm{m}]$} & thickness of bed load layer \\
\hline \multirow[t]{2}{*}{ A } & {$[-]$} & constant \\
\hline & {$\left[\mathrm{m}^{2}\right]$} & wetted area \\
\hline$A_{1}$ & {$[\mathrm{~m}]$} & constant \\
\hline \multirow[t]{2}{*}{$A_{G R}$} & {$[-]$} & treshold mobility number, value of $\mathrm{F}_{\mathrm{GR}}$ at incipient motion (Ackers and \\
\hline & & White) \\
\hline$b_{1}$ & {$[-]$} & shape factor \\
\hline$b_{2}$ & {$[-]$} & coefficient \\
\hline B & {$[-]$} & constant \\
\hline c & {$[\mathrm{Pa}]$} & macroscopic shear strength \\
\hline$c_{\vee}$ & {$\left[\mathrm{m}^{2} \mathrm{~s}^{-1}\right]$} & consolidation coefficient \\
\hline \multirow[t]{4}{*}{$\mathrm{C}$} & {$[-]$} & constant \\
\hline & {$[N]$} & cohesion \\
\hline & {$[\%]$} & percentage clay (by weight) \\
\hline & {$\left[\mathrm{kgm}^{-3}\right]$} & suspended sediment concentration \\
\hline$C_{D}$ & {$[-]$} & drag coefficient \\
\hline $\mathrm{C}_{\mathrm{eq}}$ & {$\left[\mathrm{kgm}^{-3}\right]$} & concentration of suspended sediment at equilibrium conditions \\
\hline $\mathrm{C}_{\mathrm{L}}$ & {$[-]$} & lift coefficient \\
\hline $\mathrm{C}_{\mathrm{o}}$ & {$\left[\mathrm{kgm}^{-3}\right]$} & initial concentration of suspended sediment \\
\hline $\mathrm{d}$ & {$[\mathrm{m}]$} & grain diameter \\
\hline$d_{35}$ & {$[\mathrm{~m}]$} & grain size indicating that $35 \%$ of the material (by weight) is finer \\
\hline $\mathrm{d}_{50}$ & {$[\mathrm{~m}]$} & grain size indicating that $50 \%$ of the material (by weight) is finer \\
\hline$d_{c}$ & {$[\mathrm{~m}]$} & equivalent grain size, assuming a uniform material \\
\hline$d_{s}$ & {$[\mathrm{~m}]$} & specific grain size, characterising the sediment \\
\hline $\mathrm{D}$ & {$[\mathrm{m}]$} & grain diameter \\
\hline & {$[N]$} & drag force \\
\hline
\end{tabular}




$$
\left[\mathrm{kgs}^{-1} \mathrm{~m}^{-2}\right] \text { deposition rate }
$$

$\mathrm{E} \quad\left[\mathrm{kgs}^{-1} \mathrm{~m}^{-2}\right] \quad$ erosion rate

$E_{f} \quad\left[\mathrm{kgs}^{-1} \mathrm{~m}^{-2}\right] \quad$ floc erosion rate

$\mathrm{E}_{\mathrm{h}} \quad[-] \quad$ entrainment function

$E_{m} \quad\left[k g s^{-1} \mathrm{~m}^{-2}\right] \quad$ erosion constant

$\mathrm{F}_{\mathrm{a}} \quad[\mathrm{N}] \quad$ adhesive force

$F_{c} \quad[N] \quad$ cohesive force

$F_{\mathrm{GR}} \quad[-] \quad$ sediment mobility number (Ackers and White)

g $\left[\mathrm{ms}^{-2}\right] \quad$ acceleration of gravity

gs $\quad\left[\mathrm{kgs}^{-1} \mathrm{~m}^{-1}\right]$ bed load sediment transport rate per unit width

$\mathrm{g}_{\mathrm{se}} \quad\left[\mathrm{kgs}^{-1} \mathrm{~m}^{-1}\right] \quad$ equilibrium transport rate per unit width

$\mathrm{g}_{\text {sus }} \quad\left[\mathrm{kgs}^{-1} \mathrm{~m}^{-1}\right] \quad$ sediment transport rate in suspension per unit width

$\mathrm{G}_{\mathrm{GR}} \quad[-] \quad$ dimensionless sediment transport rate (Ackers and White)

h $[\mathrm{m}] \quad$ water depth

$\mathrm{H} \quad[\mathrm{m}] \quad$ water depth

$I_{1}, I_{2} \quad[-] \quad$ integrals in Einstein's expression for suspended load transport

$k, k^{\prime}, k^{\prime \prime}[-] \quad$ constants in the erosion criterion of Partheniades

$\mathrm{k}_{\mathrm{b}}^{\prime} \quad[\mathrm{m}] \quad$ equivalent grain roughness

$k_{s} \quad[\mathrm{~m}] \quad$ rougness height, equivalent sand roughness

$\mathrm{K} \quad[-] \quad$ homogeneity coefficient

[m] roughness coefficient

$\mathrm{l}_{\mathrm{b}} \quad[\mathrm{m}] \quad$ thickness of near bed zone

L $\quad[N] \quad$ lift force

m [-] exponent

[\%] moisture content

[Nsm $\left.{ }^{-1}\right] \quad$ pseudo-plastic viscosity

n $\quad[-] \quad$ dimensionless velocity fluctuations $u_{t}^{\prime} / \sigma_{u}$ (normally distributed)

$[-] \quad$ exponent

[-] porosity of a sediment bed expressed as the ratio between the volume of the pores and the total volume 
$\mathrm{n}_{\max } \quad[-] \quad$ value of the dimensionless velocity fluctuations, $\mathrm{n}$, at incipient motion conditions (safety coefficient)

$\mathrm{N} \quad\left[\mathrm{m}^{-2}\right] \quad$ number of particles per unit surface area

$\mathrm{N}_{\mathrm{d}} \quad\left[\mathrm{m}^{-2} \mathrm{~s}^{-1}\right] \quad$ number of grains deposited per unit time and per unit bed area

$\mathrm{N}_{e} \quad\left[\mathrm{~m}^{-2} \mathrm{~s}^{-1}\right] \quad$ number of grains eroded per unit time and per unit bed area

$\mathrm{Nr} \quad\left[\mathrm{m}^{-2}\right] \quad$ number of particles available for erosion

$\mathrm{p} \quad[-] \quad$ probability that a grain/particle/aggregate will deposit

[-] probability that a grain/particle/aggregate will erode

$\mathrm{P}_{\text {inc }}[-] \quad$ probability for erosion at incipient motion conditions

$\operatorname{Pr} \quad[-] \quad$ probability that a particle will erode

$\mathrm{q}_{\mathrm{b}} \quad\left[\mathrm{m}^{3} \mathrm{~s}^{-1} \mathrm{~m}^{-1}\right] \quad$ volumetric bed load transport per unit width

Q $\quad\left[\mathrm{m}^{3} \mathrm{~s}^{-1}\right] \quad$ discharge

r $\quad[-] \quad$ roughness ratio, $\mathrm{k}_{s} / \mathrm{d}_{35}$

[-] regression coefficient

$r_{1} \quad[\mathrm{~m}]$ particle radius along the axis of symmetry

$r_{2} \quad[\mathrm{~m}] \quad$ particle radius perpendicular to $r_{1}$

$\mathrm{R}$ [m] hydraulic radius

$[-] \quad$ aspect ratio of a particle, $r_{1} / r_{2}$

$\mathrm{R}_{\mathrm{b}} \quad[\mathrm{m}] \quad$ hydraulic radius of the bed

$\operatorname{Re} \quad[-] \quad$ Reynolds number, $\mathrm{Ud} / \nu$

Re. $[-] \quad$ grain Reynolds number, $u . d / v$

$s \quad[-] \quad$ ratio of the sediment density to the fluid density

$s_{u} \quad[-] \quad \sigma_{u}$ divided by the time mean velocity $\bar{u}_{t}(0.164)$

$\mathrm{S} \quad\left[\mathrm{m}^{2}\right] \quad$ surface area of a particle

$\mathrm{S}_{\mathrm{e}} \quad[-] \quad$ slope of the energy line

$S_{0} \quad[-] \quad$ bottom slope of the flume

t [s] time

$\mathrm{t}^{\tau_{\mathrm{o}}} \quad[\mathrm{s}] \quad$ time required for the breaking of a cohesive particle

$\Delta \mathrm{t} \quad[\mathrm{s}] \quad$ time step

$\mathrm{T}$ [m] dimensionless excess shear stress (van Rijn)

[s] period of growth of a laminar sublayer (Partheniades) 


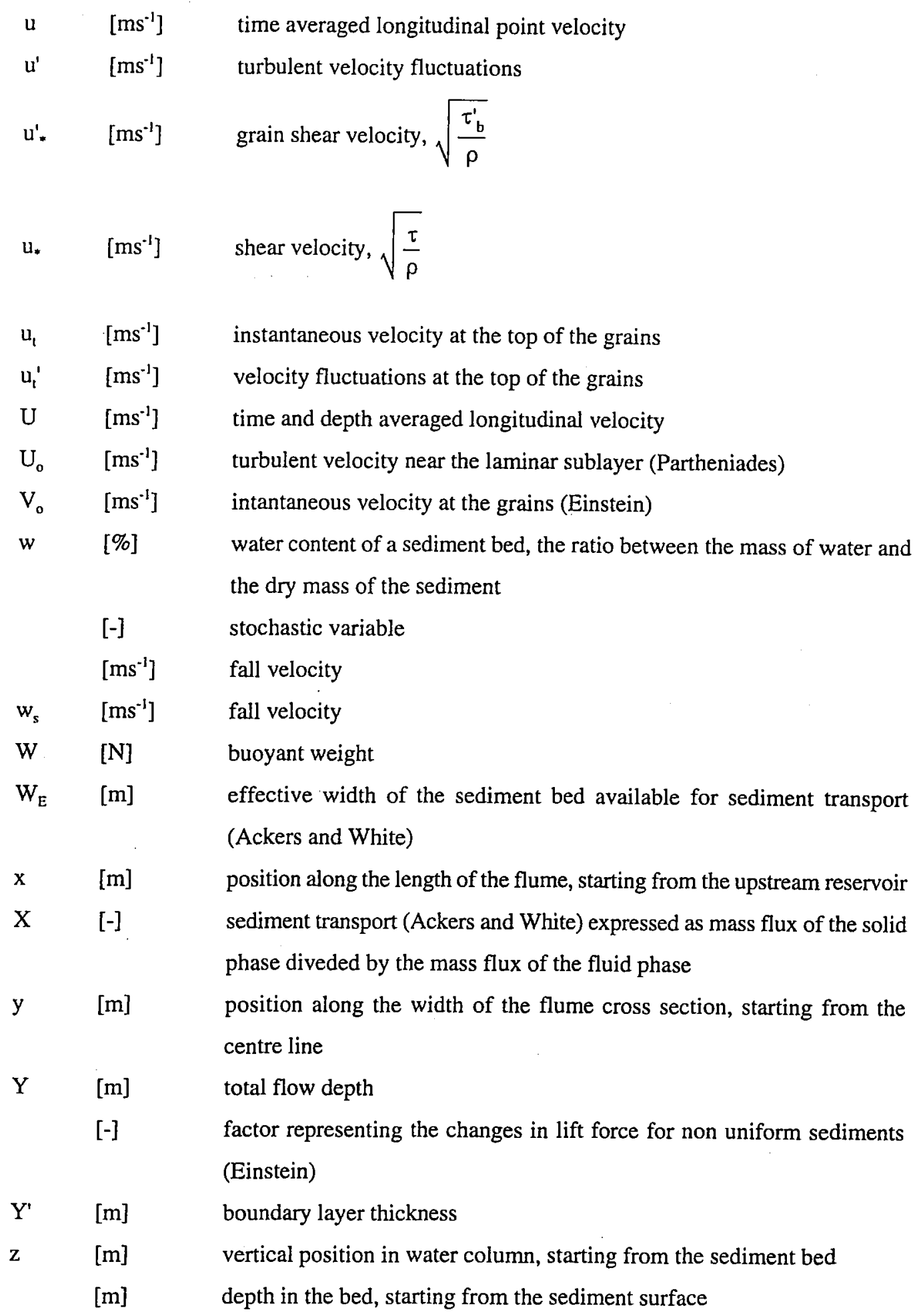




\begin{tabular}{|c|c|c|}
\hline $\mathrm{z}_{\mathrm{e}}$ & {$[\mathrm{m}]$} & depth of erosion \\
\hline$z_{0}$ & {$[\mathrm{~m}]$} & $\begin{array}{l}\text { reference level in Prandtl-von Karman velocity profile, at whi } \\
\text { velocity is equal to zero }\end{array}$ \\
\hline$\%$ fines & {$[\%]$} & the percentage of particles (by weight) smaller than $63 \mu \mathrm{m}$ \\
\hline$\alpha$ & {$[-]$} & coefficient \\
\hline$\alpha_{1}$ & {$[-]$} & area shape coefficient, $\alpha_{1} \mathrm{~d}_{\mathrm{e}}{ }^{2}=$ bed area per grain, including voids \\
\hline$\alpha_{2}$ & {$[-]$} & $\alpha_{1} C_{L} / C_{D}$ \\
\hline$\alpha_{3}$ & {$[-]$} & volumetric shape factor, $\alpha_{3} \mathrm{~d}_{e}^{3}=$ volume of a grain \\
\hline$\beta$ & {$[-]$} & exponent \\
\hline$\delta$ & {$[-]$} & standard deviation for the normal distribution of cohesion \\
\hline$\dot{\gamma}$ & {$\left[\mathrm{s}^{-1}\right]$} & shear rate \\
\hline$\zeta$ & {$[-]$} & coefficient \\
\hline & {$[-]$} & hiding factor (Einstein) \\
\hline$\eta$ & {$[-]$} & stochastic variable \\
\hline$\eta_{0}$ & {$[-]$} & standard deviation of $\eta(0.5)$ \\
\hline$\theta$ & {$[-]$} & Shields parameter, dimensionless shear stress \\
\hline$\theta_{\mathrm{b}}$ & {$[-]$} & dimensionless bed shear stress \\
\hline$\theta_{b}^{\prime}$ & {$[-]$} & dimensionless grain shear stress, grain mobility number \\
\hline$\theta^{\prime \prime}{ }_{b}$ & {$[-]$} & dimensionless form shear stress \\
\hline$\theta_{\text {cr }}^{\prime}$ & {$[-]$} & value of the dimensionless grain shear stress at incipient motion \\
\hline$\kappa$ & {$[-]$} & von Karman coefficient $(0.4)$ \\
\hline$\lambda$ & {$[-]$} & parameter in defining the elementary step length (Einstein) \\
\hline$\mu$ & {$[\mathrm{m}]$} & average step length of a coarse cohesionless particle (Einstein) \\
\hline & {$\left[\mathrm{Nsm}^{-1}\right]$} & dynamic viscosity \\
\hline$\mu_{\mathrm{B}}$ & {$\left[\mathrm{Nsm}^{-1}\right]$} & Bingham viscosity \\
\hline$v$ & {$\left[\mathrm{~m}^{2} \mathrm{~s}^{-1}\right]$} & kinematic viscosity of water \\
\hline$\xi$ & {$[-]$} & exponent \\
\hline$\rho$ & {$\left[\mathrm{kgm}^{-3}\right]$} & density of water \\
\hline$\rho_{b}$ & {$\left[\mathrm{kgm}^{-3}\right]$} & bulk density of the sediment bed \\
\hline$\rho_{d}$ & {$\left[\mathrm{kgm}^{-3}\right]$} & dry density of the sediment bed \\
\hline
\end{tabular}




\begin{tabular}{|c|c|c|}
\hline$\rho_{s}$ & {$\left[\mathrm{kgm}^{-3}\right]$} & sediment density $\left(\approx 2650 \mathrm{~kg} / \mathrm{m}^{3}\right)$ \\
\hline$\rho_{\text {surf }}$ & {$\left[\mathrm{kgm}^{-3}\right]$} & dry density of the surface layer \\
\hline$\sigma$ & {$[\mathrm{Pa}]$} & normal stress \\
\hline$\sigma^{\prime}$ & {$[\mathrm{Pa}]$} & effective stress \\
\hline$\sigma_{\max }$ & {$[\mathrm{Pa}]$} & $\begin{array}{l}\text { maximum tensile stress at each interparticle bond at the surface of a } \\
\text { cohesive bed (Partheniades) }\end{array}$ \\
\hline$\sigma_{u}$ & {$\left[\mathrm{~ms}^{-1}\right]$} & standard deviation of the velocity fluctuations \\
\hline$\tau$ & {$[\mathrm{Pa}]$} & shear stress \\
\hline$\tau_{b}$ & {$[\mathrm{~Pa}]$} & bed shear stress \\
\hline$\tau_{\mathrm{B}}$ & {$[\mathrm{Pa}]$} & Bingham yield stress \\
\hline$\tau_{\text {centre }}$ & {$[\mathrm{Pa}]$} & centre line bed shear stress, calculated from the velocity distribution \\
\hline$\tau_{\mathrm{cr}}$ & {$[\mathrm{Pa}]$} & time averaged, critical bed shear stress for erosion \\
\hline$\tau_{d}$ & {$[\mathrm{~Pa}]$} & critical shear stress for deposition \\
\hline$\tau_{\max }$ & {$[\mathrm{Pa}]$} & instantaneous maximum shear stress (incipient motion) \\
\hline & {$[\mathrm{Pa}]$} & maximum of the bed shear stress distribution over the cross section \\
\hline$\tau_{\text {mean }}$ & {$[\mathrm{Pa}]$} & mean value of the bed shear stress distribution over the cross section \\
\hline$\tau_{0}$ & {$[\mathrm{~Pa}]$} & instantaneous bed shear stress at incipient motion \\
\hline$\tau_{s}$ & {$[\mathrm{~Pa}]$} & shear strength of a cohesive soil \\
\hline$\tau_{\text {swc }}$ & {$[\mathrm{Pa}]$} & $\begin{array}{l}\text { bed shear stress calculated using the Vanoni-Brooks side wall elimination } \\
\text { method }\end{array}$ \\
\hline$\tau_{y}$ & {$[\mathrm{~Pa}]$} & yield stress \\
\hline$\phi$ & {$[-]$} & angle of repose, particle packing angle \\
\hline$\phi_{\mathrm{a}}$ & {$[-]$} & volume fraction, fraction of the total volume occupied by sediment \\
\hline$\phi_{\mathrm{ac}}$ & {$[-]$} & critical volume fraction below which the soil is a fluid supported slurry \\
\hline$\phi_{f}$ & {$[-]$} & volume fraction of the fines in the sediment mixture \\
\hline$\Phi$ & {$[-]$} & intensity of the bed load (Einstein) \\
\hline$\Psi$ & {$[-]$} & flow intensity (Einstein) \\
\hline
\end{tabular}




\section{Chapter 1: Introduction}

\subsection{Why study the erosion of mud/sand mixtures ?}

Mud can be described as a mixture of water, fine particles (clay and non-clay minerals) with a grain size below $63 \mu \mathrm{m}$ and mostly an important organic content. The clay fraction (smaller than $2 \mu \mathrm{m}$ ) is responsible for the cohesion and the presence of organic material results in even more complex bonds between the particles. Cohesion is the self-sticking property of particles, resulting from electrochemical and Van der Waals forces. Adhesion is a more general description of interparticle attraction that also includes e.g. biological binding. Sand, on the other hand, is a cohesionless material made up of a mixture of grains ranging from $63 \mu \mathrm{m}$ up to $2 \mathrm{~mm}$ in size. Cohesionless sediments consist of individual particles without any bonds; all interactions are caused by gravity or friction.

The erosion and transport of sand has been studied for a long time by many researchers and is nowadays relatively well understood. Many theories and formulas exist that describe the initiation of particle motion as well as the resulting sediment transport rates. The erosion of cohesive sediments has only been extensively studied during the last 20 to 30 years, mainly because of a growing environmental concern: mud particles can adsorb a large number of contaminants and therefore, their behaviour needs to be examined carefully. The processes leading to the erosion and transport of cohesive sediments are a lot more complex due to the large number of parameters involved: not only the properties of the sediment, but also the characteristics of the pore- and eroding fluid are important. However, also for the erosion and transport of cohesive sediments several empirical equations have been developed.

Mud and sand have completely different properties and behaviour; they are usually treated separately in erosion and sediment transport studies. In reality, however, they are frequently encountered together, both in estuaries and coastal zones as well as in combined sewer systems, and the mutual interactions between the two fractions can be important, depending on the mixture composition. 
The natural sediments in tidal rivers, estuaries and coastal zones are usually a mixture of sand and mud (Bestuur Geotechniek 1977, 1978\&1979, Houwing 1994, Williamson 1991). The understanding of the behaviour of these sediments is important for the maintenance of minimal navigable depths, the organisation of dredging activities, the disposal of the dredged sediments in situ and the extension and maintenance of harbours, among others. Therefore, the settling, deposition and erosion of mud/sand mixtures was one of the aspects studied in the European G8M Coastal Morphodynamics Programme (MAST2), Project 4: Cohesive Sediments. Part of the research described in this thesis has been carried out in the framework of this MAST programme (MArine Science and Technology). The cohesive sediments project groups a number of excellent European research institutes involved in laboratory work, field surveys or numerical modelling. Via the project the author had access to a lot of data and experience. Especially for the study of mud/sand mixtures a close collaboration with $\mathrm{HR}$ Wallingford resulted in an interesting exchange of information (Torfs et al. 1995, Williamson et al. 1995).

Although the sediments in combined sewers can also be described as mud/sand mixtures (Alvarez 1990, Wotherspoon 1994), the origin of the cohesion of sewer sediments are merely chemical and biological processes and not the classical electrochemical forces (Verbanck et al. 1994). Maybe, these materials are better described as cohesive-like. The sediments in sewers are responsible for a reduced hydraulic capacity and can provoke important maintenance costs. During severe storm conditions part of the flow is directly discharged into natural water courses via overflows, therefore, the erosion of the possibly contaminated bottom sediments needs to be controlied. Due to growing concern for ecological problems and the increasing regulations related to water quality, the sediments in sewers are the subject of many international and national studies. The IAWQ/IAHR Joint Committee on Urban Storm Drainage started a Task Group on Real Sewer Sediments in 1992. The group is currently preparing a scientific and technical report on "Sewer Solids: state-of-the-art". The experiments presented in this thesis started in the framework of a Belgian interuniversity F.K.F.O. project (Fonds voor Kollectief Fundamenteel Onderzoek), entitled: "Erosion, sedimentation and resuspension of partly cohesive sediments, especially in unsteady flow conditions" which ran from 1990 until 1995 (F.K.F.O.project nr 2.9012.90). The project involved a close collaboration between five Belgian universities: Katholieke Universiteit Leuven, Université Catholique de Louvain, Universiteit 
Gent, Université de Liège and Vrije Universiteit Brussel, together with two hydraulic laboratories: Waterbouwkundig Laboratorium Borgerhout and Laboratoire Hydraulique de Châtelet. The research consisted of laboratory as well as field measurements, e.g., in the sewers of Brussels and Louvain-la-Neuve and in the Scheldt river at Temse. The erosion experiments carried out in the laboratory in Gent were very similar to the experiments carried out by the author, only the shape of the cross section of the experimental flume differed: a semi-circular cross section (Gent) compared to a rectangular cross section (Leuven). In this way shape effects have been studied (F.K.F.O. 1994).

\subsection{Objectives and scope of the study}

The above description clearly demonstrates the importance of fundamental research on the erosion and transport mechanisms of mud/sand mixtures. This study will in fact deal with two aspects of the behaviour of mud/sand mixtures in uniform flow conditions. First of all the erosion of mixtures of cohesionless and cohesive sediments with uniform properties over depth will be examined. The amount of fine material in the sediment will gradually be increased and the impact of the increasing cohesive fraction on the erosion resistance and mode of erosion of the homogeneous mixture will be assessed. However, a natural sediment bed in an estuary or a sewer is formed by deposition from a suspension and will be highly stratified: not only the density but also the mixture composition will vary throughout the depth of the deposit. Hence, secondly, the formation and the properties of the sediment bed as a function of the composition of the suspension will be studied. Furthermore, the erodibility and mode of erosion of the layered bed in uniform flow will be followed.

The main goal of this research is trying to understand the behaviour of mixtures of cohesionless and cohesive sediments in uniform flow conditions, based on the existing knowledge about the erosion and transport of both cohesionless and cohesive sediments and to understand the physical processes involved. The most important aspects of this behaviour are the determination of the erosion resistance of a certain sediment mixture and the resulting erosion and transport rates in given flow conditions. To reach this goal laboratory experiments will be carried out to assess the 
influence of certain parameters while others are kept constant, so that the different mechanisms, responsible for the erosional behaviour of mixed sediments, can be revealed.

The main objective can be divided in several smaller aims:

1. To study the erosion resistance of homogeneous (no density gradients) mud/sand mixtures as a function of mixture composition, i.e., by gradually increasing the amount of fine material in the mixture. Also the type of cohesive sediment used in the mixtures will be varied.

2. To study the mode of erosion and erosion rates of these homogeneous mixtures in uniform flow conditions, especially focussing on the transition from cohesionless to cohesive behaviour.

3. To study the formation of a layered deposited sediment bed and check the influence of the sand content of the initial suspension on the resulting bed density profile and layer thickness.

4. To study the erosion resistance, mode of erosion and erosion rates of the layered sediment beds in uniform flow conditions.

5. Using the experimental data, the next aim is to develop a physical explanation for all encountered phenomena via the structural changes of the sediment bed at increasing content of fine material.

6. To formulate some engineering guidelines on modelling the erosion of mud/sand mixtures in uniform flow and to determine which information about the sediments and the about the flow field is necessary in order to solve some practical problems.

\subsection{Structure of the research}

Before starting the experimental study on the erosion of mud/sand mixtures, the current knowledge on the erosion and transport of pure cohesive and pure cohesionless sediments is summarized in Chapter 2. This chapter contains also a review of the available information on mixture behaviour. 
Since it was decided to conduct an experimental laboratory study, Chapter 3 discusses the choice of the experimental installation and the used measuring-instruments and techniques. The experimental methodology will be explained and the data processing techniques will be evaluated. Especially the accuracy and sensitivity of bed shear stress calculations are discussed, because the bed shear stress is the most important parameter governing erosion and sediment transport processes. For the other measured and calculated parameters, an overview of the accuracy is given in Appendix 2.

Chapter 4 brings together all the results of the experimental study on both homogeneous and layered sediment mixtures. The observed erosion processes are described, the measured erosion resistance and erosion rates are discussed. An overview will be given of the impact of mixture composition, i.e., type and amount of cohesive material, the effect of bed density and consolidation time and the influence of the stratification of the bed. For the experiments on layered sediment deposits, also the bed formation processes are followed in detail.

Using the results of similar experiments carried out in a flume with a semi-circular cross section together with field data from the river Scheldt and the Brussels sewer, Chapter 5 discusses the influence of the shape and the scale of the flume cross section on the calculation of bed shear stresses.

Based on the experimental data and observations, in Chapter 6 a physical explanation for the encountered phenomena, in terms of the changes in the internal structure of the sediment mixture, will be proposed and visualised using microscopic images. Furthermore, the possibilities to predict the erosion resistance and erosion rates of mud/sand mixtures will be explored.

Finally, Chapter 7 presents the general conclusions of this research and formulates some recommendations for future research. 


\section{Chapter 2: Erosion and sediment}

\section{transport in uniform flow}

\subsection{Introduction}

Sediment transport of cohesionless material in rivers has been the subject of scientific studies for a long time. In $1879 \mathrm{Du}$ Boys presented one of the first sediment transport formulas. In 1936 Shields developed his well known diagram for the onset of erosion of non cohesive particles. And since then, many theories and formulas have been published: the erosion and transport of (uniform) cohesionless material is quite well understood. Research on cohesive sediments only began some 40 years ago. Especially because of the environmental problems related to the transport of cohesive sediments, this topic has recently become more and more important: e.g., the European MAST G6 and G8M projects on Coastal Morphodynamics attributed a topic to Cohesive Sediments; supported by the IAWQ/IAHR Joint Committee on Urban Storm Drainage, a Task Group on Real Sewer Sediments has been formed studying among other things the cohesive-like properties of sewer sediments. Major advancements in the field of cohesive sediment research have been made as presented e.g., at INTERCOH'94, the 4th International Nearshore and Estuarine Cohesive Sediment Transport Conference.

This chapter will give an overview of the present knowledge on the erosion and transport of non cohesive ( $(2.2)$ as well as cohesive sediments $(\S 2.3)$. The basic principles of erosional behaviour and some examples of transport formulas are presented. Paragraph 2.4 deals with mixed cohesive/non cohesive sediments and discusses some aspects of mixture behaviour. At the end of this chapter all information is briefly summarized. 


\subsection{Cohesionless sediments}

\subsubsection{Incipient motion}

The erosion and transport of cohesionless sediments is dependent on the size distribution and the shape of the particles and on the flow structure. Indeed, whether a cohesionless grain will move, can be determined from forces acting on that grain (Figure 2.1): the drag (D) and lift (L) force are the active forces and the buoyant weight (W) and friction are resisting the movement.

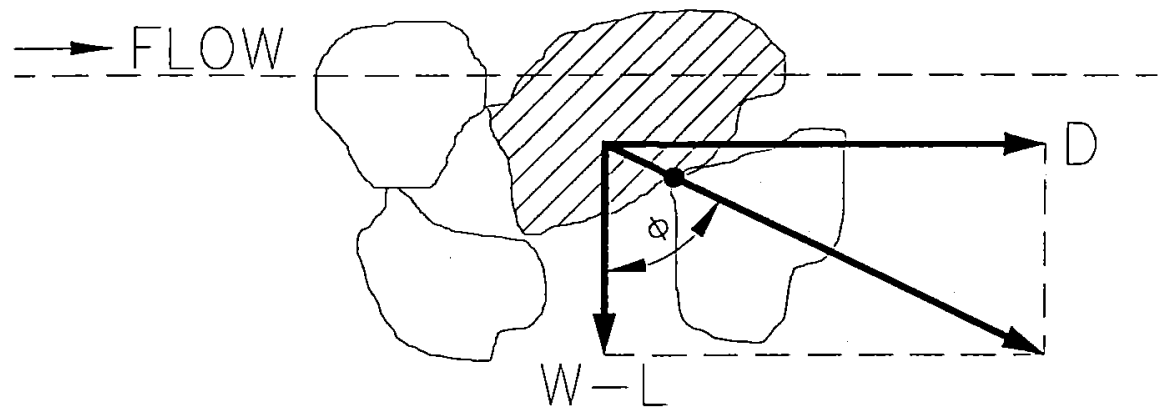

Figure 2.1: Forces acting on a grain at incipient motion.

Hence, at incipient motion:

$$
\frac{\mathrm{D}}{\mathrm{W}-\mathrm{L}} \succeq \tan \phi
$$

in which $\phi=$ the angle of repose of the sediment.

Given $\tau_{\mathrm{o}}$ the bed shear stress at the threshold for erosion, the drag and lift forces at incipient motion can be expressed as:

$\mathrm{D}=\tau_{\mathrm{o}} \alpha_{1} \mathrm{~d}_{\mathrm{e}}{ }^{2}$, with $\alpha_{1}$ an area shape factor $\left(\alpha_{1} \mathrm{~d}_{\mathrm{e}}{ }^{2}\right.$ is the bed area per grain including the voids) and $\mathrm{d}_{e}$ an equivalent grain size assuming a uniform bed material;

$\mathrm{L}=\tau_{0} \alpha_{2} \mathrm{~d}_{e}^{2}$, with $\alpha_{2}=\alpha_{1} \mathrm{C}_{\mathrm{L}} / \mathrm{C}_{\mathrm{D}}$.

An expression for $\frac{\bar{L}}{\bar{D}}$ or $\frac{C_{L}}{C_{D}}$ was derived empirically by Christensen (1972): 


$$
\frac{\overline{\mathrm{L}}}{\overline{\mathrm{D}}}=0.556\left[\ln \left(\frac{10.4}{\mathrm{r}}+1\right)\right]^{2}
$$

with $r$ the ratio between the equivalent sand roughness of the bed $\left(k_{s}\right)$ and the diameter $d_{35}$ characterising the sediment.

The buoyant weight $\mathrm{W}=\alpha_{3} \mathrm{~g}\left(\rho_{\mathrm{s}}-\rho\right) \mathrm{d}_{\mathrm{e}}{ }^{3}$, with $\rho_{\mathrm{s}}$ the sediment density, $\rho$ the fluid density, $\alpha_{3} \mathrm{a}$ volumetric shape factor. Substituting these expressions in equation (2.1) results in:

$$
\frac{\tau_{o}}{g\left(\rho_{s}-\rho\right) d_{e}}=\frac{\alpha_{3} \tan \phi}{\alpha_{1}+\alpha_{2} \tan \phi}
$$

The left hand side of equation (2.3) is the well known Shields parameter. The right hand side is a sediment-dependent parameter, $\theta$, which is in fact a function of the grain Reynolds number $\operatorname{Re}_{*}=u_{*} d_{e} / v$. For $\operatorname{Re}_{*}<5$, smooth flow conditions, the viscous stresses entrain the particles and the drag and lift coefficients are a function of $\mathrm{Re}_{*}$. Only for $\mathrm{Re}_{.}>100$, i.e., fully rough turbulent flow, $\theta$ is independent of $\mathrm{Re}_{\text {. }}$ In between a transition zone exists. Equation (2.3) can be theoretically extended to include this dependency. A graphical representation of equation (2.3), based on experimental research, is given in the Shields diagram (Figure 2.2).

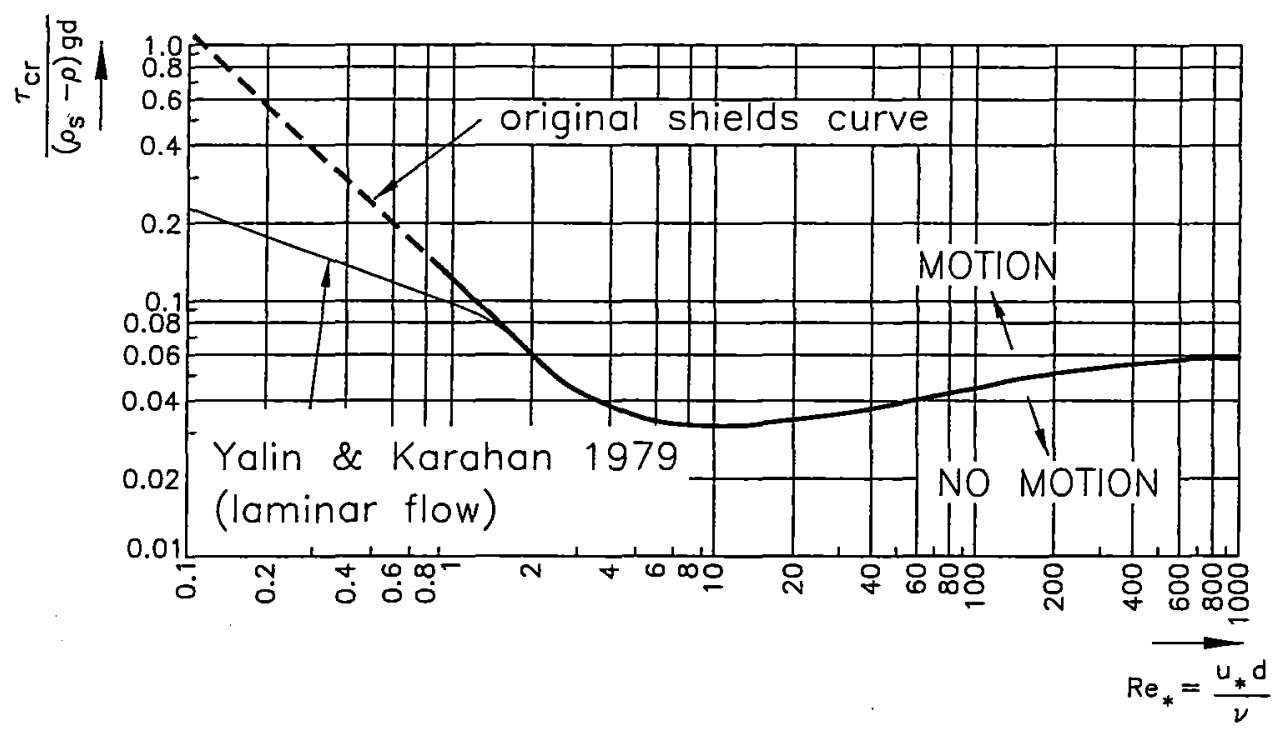

Figure 2.2: Shields diagram (Berlamont 1981, Yalin et al. 1979). 
Due to turbulence, velocities (u) -and hence shear stresses, which are a function of flow velocityfluctuate around a time average value $(\bar{u}): u=\bar{u}+u^{\prime}$. Taking these fluctuations into account equation (2.3) represents the instantaneous value of the shear stress. In fact, $\left|\tau_{0}\right|$ needs to be used since the shear stress can be both positive and negative with respect to the flow direction, depending on the local flow conditions. However, the probability of the occurrence of a negative shear stress is very low and will be neglected.

The stochastic nature of the velocity fluctuations implies that no deterministic criteria can fully describe incipient motion conditions. A probabilistic approach is needed, in which the probability for erosion at the given mean flow conditions will be determined. It is the instantaneous shear stress that moves individual particles, and since these stresses have magnitudes that fluctuate about the mean stress, some sediment transport may occur at any value of the time average bed shear stress.

The bed shear stress depends on the undisturbed flow velocity in the vicinity of the grains: $\tau_{0}$ is proportional to $u_{1}^{2}$ and $u_{t}$ is the instantaneous velocity at the top of the grains. This velocity is found to be normally distributed, with a standard deviation $\sigma_{u}$ (Christensen 1965). Hence, the bed shear stress can be written as (Christensen 1972):

$$
\tau_{0} \sim u_{t}^{2}=\bar{u}^{2}\left(1+n s_{u}\right)^{2}
$$

with $\mathrm{n}=\mathrm{u}_{\mathfrak{v}}^{\prime} / \sigma_{\mathrm{u}}$, the dimensionless velocity fluctuations, that are normally distributed and $s_{u}=\frac{\sigma_{u}}{\bar{u}_{t}}=\frac{\sqrt{\bar{u}_{t}^{12}}}{\bar{u}_{t}}$ is found to be a constant equal to 0.164 (Christensen 1972).

The time average bed shear stress is then:

$$
\bar{\tau} \sim \overline{\mathrm{u}}^{2}\left(1+\mathrm{s}_{\mathrm{u}}^{2}\right) ; \quad \overline{\mathrm{n}}^{2}=1 ; \overline{\mathrm{n}}=0
$$

At incipient motion conditions, the time average bed shear stress $\bar{\tau}$ is what is known as the (deterministic) critical shear stress for erosion $\tau_{\mathrm{cr}}$. But, since the shear stress is not a constant, even at incipient motion conditions, there is a possibility that some erosion takes place. The probability for erosion in this case, $\mathrm{p}_{\mathrm{inc}}$, is the probability that the instantaneous bed shear stress $\tau$ exceeds $\tau_{\max }, \tau_{\max }$ follows from equation (2.3). 
From equations $(2.4,2.5)$ :

$$
\frac{\tau_{\max }}{\tau_{c r}}=\frac{\left(1+n_{\max } s_{u}\right)^{2}}{\left(1+s_{u}^{2}\right)}
$$

Thus the probability for erosion at incipient motion conditions corresponds to the probability that $\mathrm{n}>\mathrm{n}_{\max }$ or according to the definitions of a normal distribution:

$$
p_{\text {inc }}=\frac{1}{\sqrt{2 \pi}} \int_{n_{\max }}^{+\infty} e^{-\frac{n^{2}}{2}} d n
$$

The value of $n_{\max }$ is then chosen so that the corresponding probability for erosion at incipient motion conditions is acceptably small. This choice of $n_{\max }$ depends on the practical application, operating conditions and safety. E.g., for $n_{\max }=3.09, p_{\text {inc }}$ is $10^{-3}$. In fact by choosing $n_{\max }$ and thus $\tau_{\max }$, a definition of incipient motion conditions is chosen. A value for the critical shear stress for erosion always needs to be accompanied by the threshold definition used to establish that value: e.g., visual observation of particle movement, very small transport rate, or, in a stochastic approach, a certain acceptable probability for erosion.

If a value for $n_{\max }$ is established, for any given hydraulic conditions, the erosion will start when the instantaneous bed shear stress exceeds the critical one:

$$
\bar{\tau}\left(1+n s_{u}\right)^{2} \succ \tau_{c r}\left(1+n_{\max } s_{u}\right)^{2}
$$

The time average bed shear stress can be calculated from the flow data as

$$
\bar{\tau}=\rho g R_{b} S_{c}
$$

with $R_{b}$ the hydraulic radius of the bed (corrected for wall effects, see Appendix 1) and $S_{e}$ the slope of the energy line.

Rewriting equation (2.3) as: $\tau_{c r}=E_{h}\left[g\left(\rho_{s}-\rho\right) d_{e}\right]$, with $E_{h}$ the entrainment function, the erosion criterion becomes:

$$
\left(1+n s_{u}\right)^{2} \succ E_{h} \Psi\left(1+n_{\max _{u}} s\right)^{2} \text { or }\left|1+n s_{u}\right| \succ \sqrt{E_{h} \Psi}\left|1+n_{\max } s_{u}\right|
$$


with $\Psi=$ the flow intensity (defined by Einstein, see p. 13). Using the Gaussian distribution for $\mathrm{n}$, the probability of erosion can be written as:

$$
\mathrm{p}=1-\frac{1}{\sqrt{2 \pi}} \int_{-\sqrt{E_{\mathrm{b}}}\left(n_{\max }+\frac{1}{s_{\mathrm{z}}}\right) \sqrt{\Psi}-\frac{1}{s_{\mathrm{p}}}}^{\left.+\sqrt{\mathrm{E}_{\mathrm{b}}\left(n_{\max }\right.}+\frac{1}{s_{\mathrm{a}}}\right) \sqrt{\Psi}-\frac{1}{s_{\mathrm{b}}}} \mathrm{e}^{-\mathrm{n}^{2} / 2 \mathrm{dn}}
$$

in which $s_{u} \approx 0.164$. If we accept $n_{\max }=3.09$, the upper and lower limits of the integral in equation (2.11) become:

$$
\mathrm{p}=1-\frac{1}{\sqrt{2 \pi}} \int_{-9.19 \sqrt{E_{\mathrm{h}} \Psi}-6.10}^{+9.19 \sqrt{\mathrm{E}_{\mathrm{h}} \Psi}-6.10} \mathrm{e}^{-\mathrm{n}^{2} / 2} \mathrm{dn}
$$

In other words, even at time average bed shear stresses smaller than the "critical bed shear stress" represented by equation (2.3), erosion can occur, with a probability expressed by the previous equation. For shear stresses higher than the critical value, erosion is very likely to occur and the probability for erosion quickly approaches 1 . Partheniades (1977) interpreted the probability for erosion as the fraction of the sediment surface that will be eroded.

\subsubsection{Sediment transport}

Once a particle is eroded from the bed it can be transported either as bed load or suspended load, depending on the flow conditions. At low values of the bed shear stress the particle moves in close contact with the bed (rolling, jumping); this mode of transport is called bed load. At higher values of fluid shear, when the upward velocity of the particle exceeds the fall velocity, the particle is completely supported by the fluid, there is no more contact with the bed; this is called suspended load. Both bed load and suspended load are bed material load, i.e., the transported sediments originate from the bed. Wash load are fine particles transported in suspension without depositing. The grain sizes of these particles are not represented in the bed material.

Numerous transport formulas have been developed for bed, suspended or total load (i.e., the sum of bed load and suspended load), based on (semi-) empirical considerations. An overview can 
be found in Berlamont (1981), Van Rijn (1989), among others. Three well-known examples, used in this study, will be given below.

\section{A. Ackers and White (Ackers 1991)}

Based on flume data, the researchers Ackers and White developed a deterministic sediment transport formula for the calculation of the total load for sediment sizes ranging from $0.06 \mathrm{~mm}$ to more than $2 \mathrm{~mm}$. The general transport function is:

$$
\left.G_{G r}=C\left[\frac{\left(F_{G r}-A_{G r}\right)}{A_{G r}}\right)\right]^{m}
$$

with $F_{G r}$ the sediment mobility number, i.e., the ratio between applied shear stress and erosion resistance, $A_{G r}$ the threshold condition, i.e., the value of $F_{G R}$ at initial motion and $G_{G R}$ a nondimensional expression for the rate of transport:

$$
G_{G R}=\left(\frac{X R}{s d_{c}}\right)\left(\frac{A}{W_{E} R}\right)^{1-n}\left(\frac{u_{*}}{U}\right)^{n}
$$

$\mathrm{X}$ is the sediment transport expressed as mass flux of the solid phase divided by the mass flux of the fluid phase, $R$ is the hydraulic radius, $s$ is the ratio of the sediment to the fluid density, $A$ is the wetted area and $W_{E}$ is the effective width of the sediment bed available for sediment transport. By the introduction of $W_{E}$ the transport formula can also be applied to circular conduits. More details on this equation are given in a recent paper by Ackers (1991).

\section{B. van Rijn (van Rijn 1989)}

Based on theoretical considerations assuming that the motion of bed load particles is dominated by saltations, van Rijn developed a bed load transport equation for particles in the range of 200 $2000 \mu \mathrm{m}$. The equation was calibrated using laboratory data.

$$
q_{b}=0.25 u^{\prime}, d_{50} T^{1.5} / D_{*}^{0.3}
$$


with $\mathrm{q}_{b}$ the volumetric sediment discharge per unit width, $\mathrm{u}^{\prime}$. the grain shear velocity, $\mathrm{T}$ the dimensionless excess shear stress and D. a particle parameter.

\section{Einstein's bed load equation (Einstein 1982, Berlamont 1981)}

A stochastic approach of the sediment transport problem is presented by Einstein (1982). He based his theory on studies of the movement of a bed load particle. Those studies showed that the movement of such a particle is a succession of periods of motion (rolling, jumping, sliding) and periods of rest. During each individual movement the distance travelled by a particle is proportional to an elementary step, $\lambda \mathrm{d}_{s}\left(\mathrm{~d}_{\mathrm{s}}=\right.$ grain diameter). If $\mathrm{p}$ is the probability that a grain will move, the average step of a particle is

$$
\mu=\frac{\lambda d_{s}}{1-p}
$$

Einstein makes the following 3 basic assumptions: steady, uniform flow conditions; the periods of transport of a grain are much shorter than the periods of rest; and $\mathrm{p}$, the probability that a grain will move, is independent of the location of the grain.

Under equilibrium conditions (i.e., stable bed) the number of grains deposited per unit time and per unit area, $\mathrm{N}_{d}$, equals $\mathrm{N}_{\mathrm{e}}$, the number of grains eroded per unit time and per unit area.

Further more, Einstein defined $\Phi$, the intensity of the bed load, and $\Psi$, the flow intensity as follows:

$$
\begin{aligned}
& \Phi=\frac{q_{b}}{\sqrt{\frac{\rho_{s}-\rho}{\rho} d_{s}^{3} g}} \\
& \Psi=\frac{\rho_{s}-\rho}{\rho} \frac{d_{s}}{S_{c} R_{b}}
\end{aligned}
$$

with $q_{b}$ the volume discharge of the sediment per unit width, $d_{s}$ the specific grain size, $s_{e}$ the slope of the energy line and $R_{b}$ the hydraulic radius of the bed.

Using these definitions the condition for stable bed, $N_{d}=N_{e}$, can be translated as 


$$
\mathrm{p}=\frac{\mathrm{A} \Phi}{1+\mathrm{A} \Phi}
$$

with $A$ a constant.

According to Einstein, the probability, $p$, that a grain will be eroded is the probability that the instantaneous lift force is bigger than the under water weight of the particle. He expressed the lift force as

$$
\mathrm{L}=\frac{1}{2} \rho \mathrm{C}_{\mathrm{L}} \mathrm{V}_{\mathrm{o}}^{2} \mathrm{~A}_{\mathrm{i}} \mathrm{d}_{\mathrm{s}}^{2}
$$

He found $C_{L}=1.78$ and he assumed the instantaneous velocity, $V_{o}$, at the grains as well as its square normally distributed.

$$
v_{0}^{2}=\vec{v}_{0}^{2}|1+\eta|
$$

$\eta=$ a stochastic parameter with a mean value of 0 and a standard deviation of $\eta_{0}$, which he found to be 0.5 .

This is incorporated in equation (2.18) and some correction factors for non uniform sediments are applied (Berlamont 1981). Finally the following bed load equation results:

$$
\frac{A \Phi}{1+A \Phi}=1-\frac{1}{\sqrt{\pi}} \int_{-\frac{1}{\eta_{0}}-B \Psi}^{-\frac{1}{\eta_{0}}+B \Psi} e^{-t^{2}} d t
$$

with $\mathrm{B}$ a constant.

Experimentally, Einstein found the following relation between the flow intensity and the bed load intensity:

$$
0.465 \Phi=\mathrm{e}^{-0.391 \Psi}
$$

Remarks: 1. This bed load function determines in fact the saturation limit of the flow for a certain sediment size. However, in order to reach this sediment transport capacity, the sediment supply rates from upstream sources must be at least equal to this capacity. Otherwise, it is not the flow but the supply rate that controls the sediment transport rate (Partheniades 1977) and net erosion or deposition will take place. The net erosion rate can be calculated as: the probability for erosion 
times the number of particles per bed area divided by the time it takes to erode one particle.

2. Also for suspended load Einstein developed a formula. He assumed that bed load takes place in a layer with thickness $a=2 d_{s}\left(d_{s}=\right.$ the specific grain size of the bed); everything above that level is considered to be suspended load. For the suspended load transport $g_{\text {sus }}$ he found the following equation:

$$
\mathrm{g}_{\text {sus }}=\mathrm{g}_{\mathrm{s}}\left[2.3 \log \left(\frac{30 \mathrm{~h}}{\mathrm{~K}}\right) \mathrm{I}_{1}+\mathrm{I}_{2}\right]
$$

in which $h$ is the water depth, $K$ a roughness dependent coefficient and $I_{1}$ and $I_{2}$ are a function of $a / h$ and $w / k_{s} u$. ( $w=$ fall velocity and $k_{s}$ the equivalent sand roughness of the bed). The values of $I_{1}$ and $I_{2}$ can be found in Berlamont (1981).

\section{Modification of Einstein's theory (Christensen 1972, Mehta et al. 1983)}

Einstein assumed that the length of a saltation is proportional to the grain size. When the active forces on a grain are considered, one can see that a jump will be bigger if the lift and drag forces increase or the weight decreases. Since the lift and drag forces are proportional to $d_{s}^{2}$ and the weight is proportional to $d_{s}^{3}$, it seems more logical to make the saltation step inversely proportional to $d_{s}$. Another remark to be made concerns the erosion criterion. Einstein stated that erosion starts when the lift force exceeds the under water weight. But also the drag force needs to be taken into account (equation (2.1)). Hence erosion could start for $L / W$ values smaller than 1 .

Using the probability for erosion calculated from equation (2.1) as explained in $\S 2.1$, the final transport formula may now be written as:

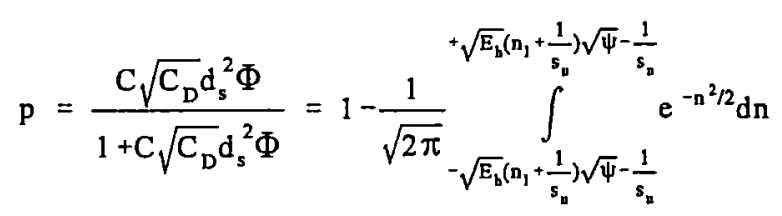

with $C_{D}$ the drag coefficient and $C$ a constant. 


\section{Calculation of flow resistance}

As soon as bed forms appear on the surface of a cohesionless sediment bed, the flow resistance consists of two parts: grain resistance and form resistance. The form drag is dissipated in the eddies generated by the bed forms. The grain resistance is needed in sediment transport formulas because only the grain shear stress is effective in the entrainment of sediment particles. Different techniques are available to separate the two components (van Rijn 1989): methods based on bed form and grain-related parameters and methods based on integral parameters. In this study a method of the second type developed by Engelund-Hansen (Perrusquia 1991) is applied.

The dimensionless bed shear stress, $\theta_{b}$, can be expressed as the total of the dimensionless grain shear stress, $\theta_{b}{ }^{\prime}$, and the dimensionless bed form shear stress, $\theta_{b}{ }^{\prime \prime}$. The dimensionless bed shear stress or mobility number is defined as

$$
\theta=\frac{\tau_{b}}{\left(\rho_{s}-\rho\right) g_{c}}
$$

with $\tau_{\mathrm{b}}=\rho u_{*}^{2}$.

For the determination of the dimensionless grain shear stress, $\tau_{b}{ }^{\prime}$, the grain shear velocity, $u_{*}^{\prime}$ can be calculated from:

$$
\frac{U}{u_{*}{ }^{\prime}}=5.75 \log \left[\frac{11 \mathrm{Y}^{\prime}}{\mathrm{k}_{\mathrm{b}}{ }^{\prime}}\right]
$$

with $U=$ the depth- and time- averaged velocity, $k_{b}{ }^{\prime}=$ the equivalent grain roughness and $\mathrm{Y}^{\prime}=$ the boundary layer thickness. Engelund and Hansen proposed $\mathrm{k}_{\mathrm{b}}{ }^{\prime}=2.5 \mathrm{~d}_{50}$ and they assumed similarity between the sediment boundary layer and the total flow:

$$
\frac{\theta_{b}^{\prime}}{Y^{\prime}}=\frac{\theta_{b}}{Y}
$$

with $Y$ the total flow depth. Hence, in an iterative way $Y^{\prime}$ and $\theta_{b}{ }^{\prime}$ can be calculated from equations $(2.26,2.27)$. And finally the grain shear stress or effective bed shear stress, needed in sediment transport calculations, can be derived from $\theta_{b}$ '. 
Particles in the immediate neighbourhood of the bed will deposit when the local lift forces become smaller than the buoyant weight of the particle. The thickness, $l_{b}$, of the near bed layer, from which particles can reach the bed depends on the flow conditions and sediment size (Partheniades 1977): $l_{b}=f\left(w_{s} / u_{.}\right) d_{e}$, with $w_{s}$ the fall velocity of the grain. Using the previously given definitions for lift and buoyant weight (see $\mathrm{p} 7$ ), the criterion for deposition is:

$$
\tau \prec \frac{\alpha_{2}}{\alpha_{3}} g\left(\rho_{s}-\rho\right) d_{c}
$$

Introducing the normal distribution for the velocity, a probabilistic criterion expressing the probability for deposition at certain flow conditions can be derived.

\subsection{Cohesive sediments}

\subsubsection{Nature of cohesive sediments}

\section{A. Properties}

Whereas cohesionless sediments can be fully characterised by their grain size distribution, cohesive sediments are more difficult to characterise (Berlamont et al. 1993). There are two fundamental differences between cohesive and non cohesive sediments (Mehta et al. 1990). Due to significant physico-chemical effects arising from surface ionic charges, suspended particles have a tendency to form large, low-density aggregates, flocs. This aggregation is enhanced by Brownian motion, differential settling and fluid shear. Hence, the settling velocity of muddy sediments is dependent on concentration and turbulence. And, secondly, once deposited on the bed, the flocs undergo consolidation. This leads to a progressive increase in density and shear resistance of the bed. Thus, the sediment bed has time dependent characteristics.

The boundary between cohesionless and cohesive materials is not very clear. However, for uniform sediments Mehta and Lee (1994) suggest that until further experimental evidence is gathered, the $20 \mu \mathrm{m}$ size may be considered practically to be the dividing size differentiating 
cohesive and cohesionless sediment transport behaviour with respect to the threshold behaviour. Since natural muds are never uniform, it is not easy to say, based on size distributions alone, when a certain material is considered to be cohesive or not.

In general mud in a aquatic environment is a mixture of clay and non-clay minerals in the silt$(2-63 \mu \mathrm{m})$ and clay-size range (smaller than $2 \mu \mathrm{m}$ ), organic matter and sometimes small quantities of very fine sand.

The finest particles, the clay minerals are mainly responsible for the cohesion, although the organic matter can contribute to cohesion and adhesion as well. Clay particles have a flat platelike shape with a large specific area. Clay minerals are crystalline and consist mostly of silicates of aluminium, iron and magnesium. These silicates are arranged in a layered structure. Kaolinite, for instance, consists of aluminium octahedral layers with parallel, superimposed silicon tetrahedral layers intergrown in such a way that the tips of the silica sheet and one of the octahedral unit form a common plane. Clay minerals show strong interparticle forces (electrochemical and Van der Waals forces) that are often much more important than gravity. The reason for these strong forces lies in the presence of a double layer around the clay particle. The surface of the clay particle is negatively charged, the edges positively. Cations from the surrounding fluid gather in a layer around the surface of the particle. The ions in the double layer can be exchanged with ions from the fluid.

From the description above it is clear that many parameters govern the properties of a cohesive sediment. One of the outcomes of the MAST G6 Coastal Morphodynamics Programme (Berlamont et al. 1993) was a list of 28 parameters necessary to characterise a mud and its behaviour under flowing water. These parameters can be grouped into physico-chemical properties of the overflowing fluid, physico-chemical properties of the sediment, characteristics of the bed structure and water-bed exchange processes. The physico-chemical properties of cohesive sediments are chlorinity, temperature, oxygen content, redox potential, $\mathrm{pH}$, gas content, organic content, Na-, K-, Mg-, Ca-, Fe-, Al-ions, CEC (cation exchange capacity), bulk density (density profile), specific surface area, mineralogical composition, grain size distribution and sand content. More details can be found in Berlamont et al. (1993) and Van Damme (1982), among others. 


\section{B. Characteristics of the sediment bed}

\section{i Settling and consolidation}

As mentioned above, a cohesive sediment bed is formed by the combined action of (hindered) settling and consolidation. The deposition process is strongly dependent on the suspension concentration. Indeed, the settling velocities of cohesive materials are properties of a suspension, not unique properties of the sediment, whereas the settling velocity of a cohesionless particle is only a function of its size and shape. The following description of the deposition process was proposed by Krone (1962).

For very low concentrations $(<300 \mathrm{mg} / \mathrm{l})$ the settling velocity of the particles is a constant, only a function of the particle size, density and shape: this process is called free settling. The suspended load concentration decreases exponentially with time. When the bed shear stress is lower than the critical shear stress for deposition $\left(\tau_{d}\right)$, settling particles that reach the bed can also adhere to it and thus deposit. At higher shear stresses the flocs are disrupted before they reach the bed and re-entrained by the flow. The critical shear stress for deposition is in fact the initial bonding strength of the flocs to the bed surface and it is the turbulent shear that controls the size and strength of the flocs remaining in suspension.

At higher suspended sediment concentrations $(300 \mathrm{mg} / \mathrm{l}-10 \mathrm{~g} / \mathrm{l})$ particles will interfere with each other and flocculation occurs. Due to increasing floc dimensions and density, the settling velocity increases with concentration: flocculation settling. The suspension concentration decreases logarithmically with time. Even for shear stresses above the critical one, a fraction of the suspended load deposits because of the diversity of floc sizes. Mehta et al. (1975) found that the ratio $\mathrm{C}_{\mathrm{eq}} / \mathrm{C}_{\mathrm{o}}\left(\mathrm{C}_{\mathrm{eq}}\right.$ is the final equilibrium concentration, $\mathrm{C}_{\mathrm{o}}$ is the initial suspended sediment concentration) is a function of the bed shear stress. Below the critical shear stress for deposition all particles will eventually deposit. The flocculation of cohesive sediments is enhanced by salinity. The critical salinity for coagulation of most clay minerals is about $3 \mathrm{~g} / \mathrm{l}$.

At very high suspended load concentrations $(>10 \mathrm{~g} / \mathrm{l})$ the settling velocity decreases with increasing concentration. The settling of the flocs is reduced by an upward flow of fluid displaced by the flocs: hindered settling. The sediment starts to form a nearly continuous network that eventually will stop any net movement of flocs or fluid, this state is generally called fluid mud. 
For each case, the rate of deposition (D) can be expressed as:

$$
\mathrm{D}=-\mathrm{pw}_{\mathrm{s}} \mathrm{C}
$$

with $C$ the near bed suspension concentration, $w_{s}$ the settling velocity (which is a function of concentration) and $\mathrm{p}$ the probability for deposition; $\mathrm{pw}_{\mathrm{s}}$ is sometimes called the apparent settling velocity.

Based on laboratory tests, Krone (1962) proposed:

$$
\begin{gathered}
p=\frac{\tau_{d}-\tau_{b}}{\tau_{d}} \quad \tau_{b} \prec \tau_{d} \\
p=0 \quad \tau_{b}>\tau_{d}
\end{gathered}
$$

When the sediment is non uniform (e.g., due to flocculation), the size distribution can be divided into several classes and equations $(2.29,2.30)$ can be used for each class, including an expression for the interclass exchange. Sanford et al. (1993) showed that models assuming no critical shear stress for deposition and hence, including continuous deposition proportional to the near bed resuspended sediment concentration $(p=1$ in equation (2.29)), describe field data much better. By using the formulation of the shear stress as given in equations $(2.4,2.5)$, the stochastic nature of the critical shear stress for deposition, due to turbulent fluctuations of the velocities, can be introduced.

When a sediment layer has settled out of a suspension, the flocs and aggregates will continue to rearrange themselves to form a denser and stronger structure. The pore water, initially supporting the sediment particles, is being expelled. This process is called consolidation. The consolidation process can be divided in two parts (Mehta et al. 1989). During the primary consolidation the sediment mass at the bed surface is balanced by the seepage force induced by the upward flow of the pore water from underlying sediment. Gradually the weight of this surface sediment turns into effective stress. Primary consolidation ends when the excess pore water pressure has completely dissipated. Then secondary consolidation starts, which is the result of a plastic deformation of the bed under a constant overburden.

Consolidation processes have to be taken into account when modelling cohesive bed erosion (Mehta et al. 1989). The erodibility of a consolidating bed decreases with time due to the 
increasing bed shear strength and also because the accompanying density increase changes the mass of sediment eroded per unit bed thickness.

Depending on the initial sediment concentration only consolidation (initial concentration higher than the gel point) or settling followed by consolidation (initial concentration lower than the gel point) will take place. The gel point indicates the transition concentration where a continuous structure is formed in the suspension, it marks the transition from suspension to unconsolidated bed (Williams et al. 1989). For estuarine muds the suspension density at the gel point seems to be around $1090 \mathrm{~kg} / \mathrm{m}^{3}$ in quiescent conditions (Toorman 1992).

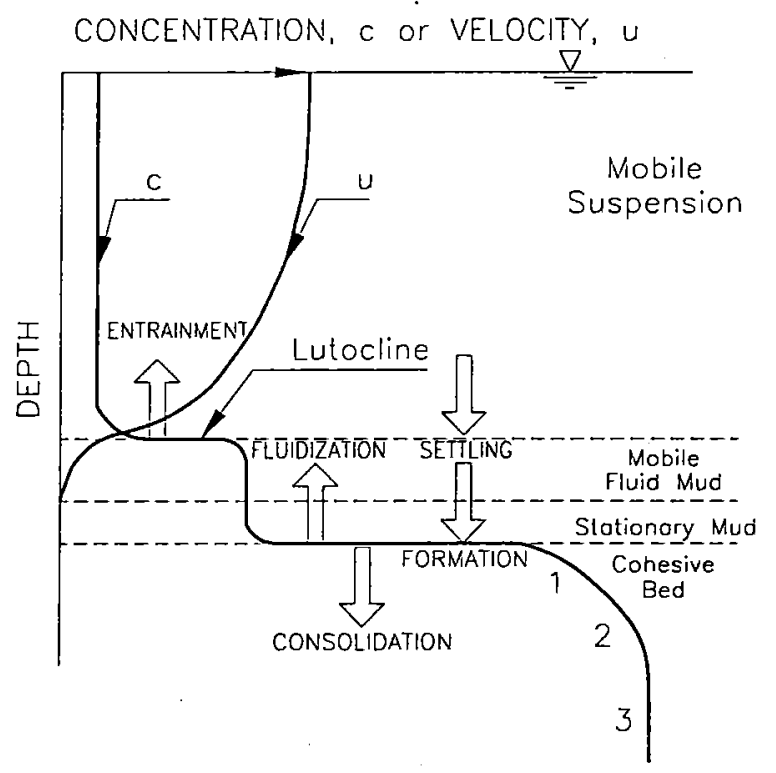

Figure 2.3: Stratified cohesive sediment bed (Mehta et al. 1990).

Due to different processes a mud bed is usually stratified. A complete picture is given in Figure 2.3 from Mehta et al. (1990). Starting from the water surface going down a first layer consists of the suspended particles (mobile suspension), then there is a strong increase in concentration (lutocline). The highly concentrated mud can either be mobile (fluid mud) or can already possess enough structural strength to be stationary. Generally fluid mud has a density around 1.03 to $1.25 \mathrm{~kg} / \mathrm{dm}^{3}$ and it develops at high suspended load concentrations. Another strong increase in mud concentration indicates the bed level. The cohesive bed is defined as that 
part having developed effective strength. In the bed again three zones can be found (Figure 2.3). Zone 1 (thickness a few centimetres) shows a sharp increase in shear strength (and density) due to consolidation and crushing of aggregates into constituent units that are more dense and stronger. This part is usually very soft. In zone 2 the shear strength gradient is a lot smaller and the shear strength reaches a maximum value and in zone 3 a constant shear strength exists (uniform bed), this part is dense and consolidated. It consists of the primary aggregates which cannot be broken due to overburden alone.

Settling and consolidation are essentially one-dimensional processes and therefore, those processes can easily be studied in the laboratory in vertically mounted settling columns (MAST 1993). However, in the field two different processes exist (Parker 1994): slow deposition creating an open porous substrate and the phase transformation at high sediment concentrations (fluid mud). Hence, it is clear that in the laboratory it is difficult to create a 'natural' mud bed. Moreover, sediments in situ may have an important element of organic binding and their slow deposition render them most unlike the rapidly deposited slurries used in the laboratory (McCave 1984). Parker (1994) suggests that correct fluxes of sediment onto the bed rather than input mass need to be reproduced in order to get a good starting point for erosion tests. Verbeek et al. (1994) found in their experiments that a placed bed of natural mud represented more the natural situation than a deposited bed.

Another major problem in laboratory experiments is that fall velocity values cannot be scaled exactly. Therefore, Mehta (1988) suggests that fall velocities should be determined in situ, whereas the value of the critical shear stress for deposition can be found from lab tests.

\section{ii Rheology}

Rheology studies the flow and deformation behaviour of materials. A rheological model for viscous materials describes the relation between shear stress $(\tau)$ and deformation or shear rate $(\dot{\gamma})$ by means of the viscosity ( $\mu$, dynamic viscosity).

$$
\tau=\mu \dot{\gamma}
$$

Because of the direct relationship between rheology and structure of mud, the rheological behaviour of mud is influenced by those parameters that also affect the strength of the aggregate 
bonds (Berlamont et al. 1993). Cohesive sediment suspensions, at concentrations above the gel point, are visco-plastic. They seem to have a yield stress, i.e., an initial shear resistance that has to be overcome before flow of the material is possible. Mud is also a thixotropic material (a material with time dependent rheological properties) and the rheological behaviour of cohesive sediments is strongly dependent on the sediment concentration (MAST 1993, Williams et al. 1989). A first distinction can be made between low and high mud concentrations (Périgaud 1983\&1984).

Low mud concentrations behave more or less like a 'fluid'. The rheology of low mud concentrations, representative for the top layer in an estuary or even in a sewer (Wotherspoon 1994), is often represented by a power law or Bingham model (Figure 2.4) with a reasonable accuracy over a limited range of shear rates. An overview of other possible models is given in Toorman (1992), MAST (1993) and Verreet et al. (1989), among others. Determining the parameters used in rheological models from laboratory tests (rheometry) is not always an easy task. Some of the encountered problems are discussed in Jones (1994), MAST (1993) and Toorman (1994).

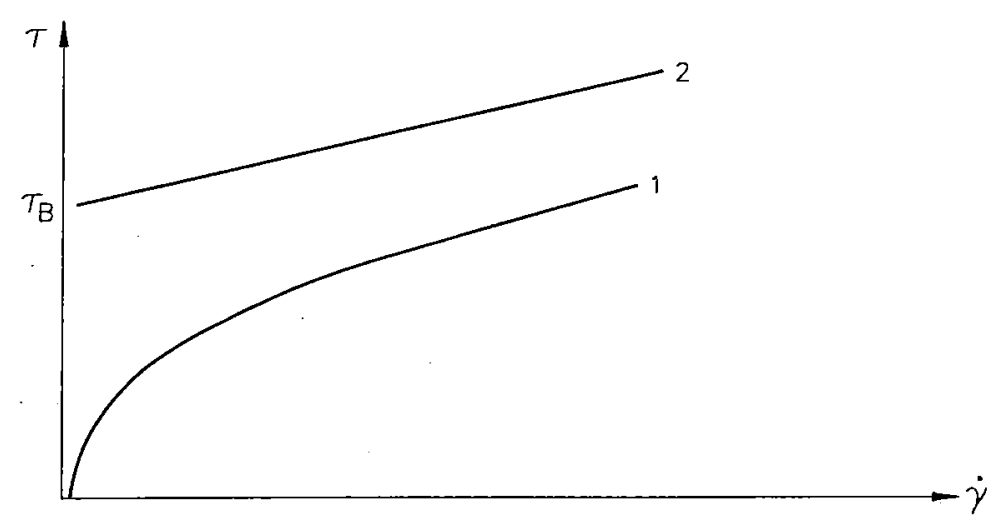

Figure 2.4: Different rheological models for low concentration suspensions.

1. Power law or Pseudo-plastic model: $\tau=m \dot{\gamma}^{\mathbf{n}}$

2. Bingham model: $\tau=\tau_{B}+\mu_{B} \dot{\gamma}$, if $\tau \geq \tau_{B}$

The parameter that is mostly used in modelling the behaviour of cohesive sediments is the (apparent) yield stress, $\tau_{y}$, i.e., the minimum shear stress corresponding to the first evidence of flow of the material. Below the yield stress no permanent deformations are encountered (Dade et 
al. 1992). Because both erosion resistance and yield strength are related to the strength and the structure of the sediment a good correlation between both is expected (Otsubo et al. 1988). That this is often not the case is due to the time-dependency of the rheological properties of most cohesive sediments. Because of thixotropy the unique relation between $\tau$ and $\dot{\gamma}$ disappears. For sewer sediments a very good correlation between yield stress, measured by a vaneviscometer, and the moisture content (m) of the sediment was found (Wotherspoon 1994):

$$
\tau_{y}=\exp (18.68) \mathrm{m}^{-3.25}
$$

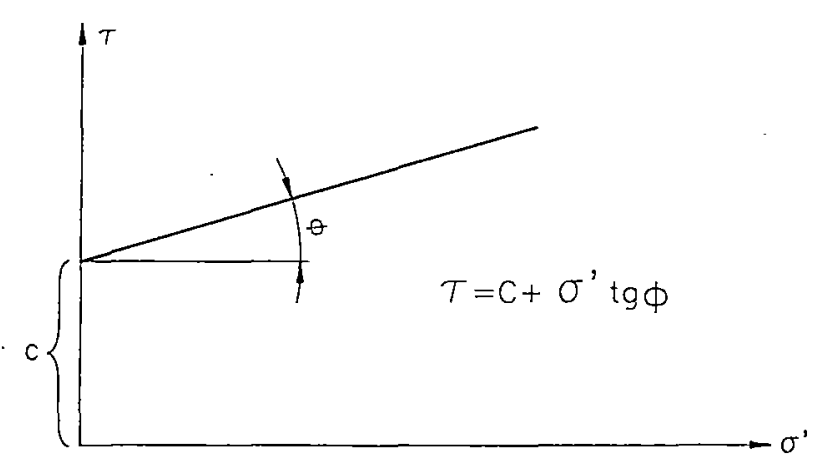

Figure 2.5: Coulomb's law for soil failure, $C$ is the cohesion, $\sigma^{\prime}$ is the effective stress and $\phi$ is the angle of internal friction.

At high mud concentrations (consolidated sediments) another, stronger structure develops, where the sediment and the pore fluid form two distinct phases. The material shows a soil mechanical behaviour, described as elastoplastic, with a Coulomb-type failure criterion (Figure 2.5). The parameters can be derived from soil mechanical tests, e.g., vane shear test.

\section{iii Biological influences}

In natural environments muds contain an important amount of organic matter. The influence of the organic matter on the properties of the mud is not very clear. Williamson (1991) described four major mechanisms by which biological activity may affect estuarine sediments. Organisms can alter the fluid momentum on the sediment bed by changing the bed roughness; mucus secreted by organisms can create extra adhesion between the particles; water circulation can be 
caused by filter feeding organisms, that also eject pseudo-faeces and pellets and the reworking of the sediments by burrowing breaks up the sediment matrix and destroys bedding sequences. Paterson (1994) found that organic matter can be neutral (no effect), it can have a negative effect (e.g., bioturbation, loosening of the sediments) or it can have a positive effect (biostabilisation). The mechanisms of biogenic stabilisation are: an alteration of the flow field (e.g., making the surface smoother), creation of networks between the particles, the presence of animal burrows and the presence of extracellular polymeric substances. Bioturbation makes originally stratified deposits become more homogeneous.

An extensive overview of possible biological influences on the properties of cohesive sediments can be found in McCave (1984), among others.

\subsubsection{Erosional behaviour of cohesive sediments}

\section{A. Modes of erosion}

Erosion of cohesive sediments is strongly dependent on the properties and the structure of the bed material. Generally three modes of erosion are distinguished (Mehta 1991), that are not fully independent from each other but that are mostly treated as such: surface erosion, mass erosion and re-entrainment of fluid mud (Figure 2.6).

Surface erosion is a slow process. Flocs, particles at the surface of the cohesive sediment bed, initially attached to their neighbours by electrochemical bonds, break up and are immediately suspended as a result of lift and drag forces. Surface erosion is the result of micro-level interactions between hydrodynamic and physico-chemical forces.

Mass erosion is the rapid dislodgement of large pieces of soil at a deeply embedded plane, presumably when the bulk shear strength of the material is exceeded. All material above that plane is immediately removed by the flow. This results in pitting of the bed. According to McCave (1984) this mode of erosion may result from form-drag on roughness elements created by an initial phase of particle-by-particle erosion. 

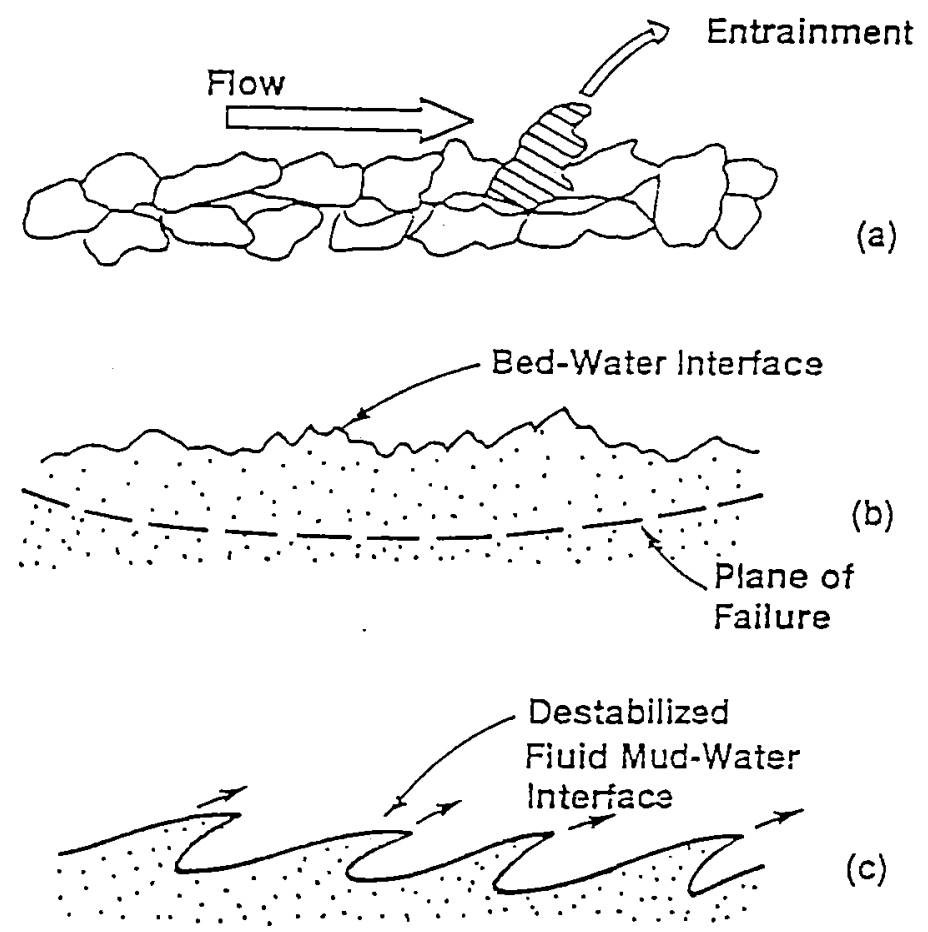

Figure 2.6: Different modes of cohesive sediment erosion (Mehta 1991).

a. Surface erosion. b. Mass erosion. c. Re-entrainment of fluid mud.

Many different definitions of fluid mud exist. Toorman (1992) defined it as a high concentration cohesive sediment suspension with a sediment volume fraction above the gel point. The fluid mud forms a layer above the sediment bed (Figure 2.3). Re-entrainment of fluid mud is caused by the destabilisation of the fluid mud-water interface. Gradually increasing undulations appear in the interface and in the end the mud is entrained by the flow. A fluid mud layer can also be eroded as a whole by tidally-induced pressure gradients.

According to Périgaud (1983) erosion is initiated by the occurrence of turbulent bursts, which are periodically disturbing the laminar sublayer. Therefore, erosion is an intermittent and stochastic process. For soft cohesive sediments these bursts produce instabilities in the sedimentwater interface resulting in entrainment of the particles. For dense sediment beds the bursts cause overpressure of the pore water and higher effective stresses, resulting in aggregates being removed from the bed. 
Mehta (1991) introduced the 'stirred layer' concept to explain surface erosion phenomena. Instead of looking at what happens at $z=0$ (only upward mass flux going to zero when denser layers are reached), he considers the level $z=\delta$ close to the bed, where simultaneous exchange occurs due to upward entrainment caused by turbulent diffusion, (decreasing) erosion from the bed and settling. If the flow stops, this stirred layer becomes part of the bed again.

Mirtskhoulava (1991) describes the erosion of a cohesive bed as follows. At first dispersed particles and particles with weaker bonds are removed. This leads to a rougher surface, which in turn increases drag and lift forces on the surface. Hence, bonds between aggregates can be broken and the aggregates can be lifted out of the bed, i.e., 'the crumbling of the surface'.

Einsele et al. (1974) found three different modes of erosion depending on bed shear strength, inhomogeneities (lamination, minute fissures) and critical mean flow velocity. The first mode of erosion was called continuously suspending erosion. Sediment is being suspended and shoal holes develop at the surface. Mostly this type of erosion stopped after $\pm 1 / 2$ hour. The second mode was discontinuous erosion. This type of erosion of crumbs, shreds or flat cakes is typical of all the sediments containing laminations or/and joints due to slight changes in sedimentation condition or differential settlements respectively. The last type of erosion was erosion with wavy surface. Particles and crumbs are disintegrated from the crests and this takes place under shooting flow of high velocities over relatively soft sediment.

According to van Kesteren et al. (1992) the top layer of a cohesive bed will fail due to swelling of the sediment. This dilatation results in an increase of the water content, so that the normal pressures and the stresses induced by the turbulent boundary layer cause a viscous flow with an unstable interface. This allows lateral transport through the viscous sublayer of the turbulent flow. The dilatation or swelling of the cohesive sediment is described as a reverse consolidation process penetrating into the bed and characterised by the consolidation coefficient $c_{\mathrm{v}}$.

Transport of cohesive sediments is a function of flow velocity (bed shear stress), turbulence and settling velocity. Once eroded, the fine material goes immediately into suspension because the buoyant weight of the fine particles or flocs can be neglected. The distribution of suspended sediment over the water column is usually more or less uniform, unless the concentrations of suspended solids are so high that stratification occurs. Only for very dense cohesive beds, erosion 
can produce dislodgement of large pieces of soil (mass erosion) which may be transported as bed load.

Many laboratory studies on the transport of cohesive sediments (e.g., Lau et al. 1994) have shown that erosion and deposition are mutually exclusive: erosion occurs when the bed shear stress rises above a critical value $\left(\tau_{\mathrm{cr}}\right)$ and deposition starts when the bottom shear stress drops below a critical value $\left(\tau_{\mathrm{d}}\right)$. The critical shear stress for erosion is greater than or equal to the critical shear stress for deposition. This is in contrast with the transport of cohesionless sediments where erosion and deposition occur simultaneously. Mutually exclusive erosion and deposition requires the total suspended load to increase as long as the bed shear stress is above the critical value for erosion, even if the bed shear stress is decreasing. Field data (Sanford et al. 1993), however, indicate that deposition begins long before the shear stress falls below the critical value. The reasons for this discrepancy can be scaling problems between laboratory and field conditions and the fact that natural sediments are a mixture of particle classes with different thresholds for each class. In the field the shear stress is less uniform and the turbulence is more variable. The probability for simultaneous erosion and deposition of a homogeneous sediment in very uniform laboratory conditions is many times smaller than the probability of simultaneous erosion and deposition occurring turbulent, irregular field conditions.

\section{B. Erosion resistance}

In contrast with cohesionless sediments, the critical shear stress for erosion of cohesive materials is a function of the 'cohesion', which in turn depends on a lot of factors (sediment composition, pore- and eroding fluid composition, degree of consolidation of the deposit, organic matter, ....). Numerous attempts have been made to relate the critical shear stress to one or more physical properties of the sediment, e.g., grain size, water content, bulk density. An overview is given in ASCE Task Committee (1968) and McCave (1984), among others. Due to the nature of cohesive sediments it is obvious that such an approach will never work. Cohesive sediments are bonded by physico-chemical and biochemical forces that cannot easily be predicted or measured. 
For example Arulanandan (1975) concluded that shear strength, plasticity index and clay content have an important bearing on the phenomenon of erosion resistance, but do not describe it completely; the chemical and environmental factors must also be considered.

Amos et al. (1985) wrote that the resistance of intertidal mud to erosion (upto $8 \mathrm{~Pa}$ ) can be 80 times higher than for sub-tidal counterparts. Subaerial exposure and dehydration are important factors for the determination of erosion resistance. Also Grissinger et al. (1963) mentioned the importance of the quantity of water in the sediment at the time of testing and of the length of time the sediment sample has been at the given water content. In general the critical shear stress for erosion decreases with increasing water content and with decreasing salinity of the water.

Natural sediment beds are never completely smooth and perfect. Therefore, Einsele et al. (1974) suggest that those soil-mechanical parameters, which are strongly influenced by inhomogeneities and the local distribution of voids (e.g., tensile strength or permeability) are better related to the erosion resistance of cohesive sediments than grain size distribution, shear strength and void ratio.

An approximate but useful relation between critical shear stress and bulk density was proposed by Mehta (1988):

$$
\tau_{s}=\zeta\left(\rho_{b}-1\right)
$$

in which $\quad \tau_{\mathrm{s}} \quad$ shear strength $[\mathrm{Pa}]$

$\rho_{\mathrm{b}} \quad$ bulk density $\left[\mathrm{kg} / \mathrm{dm}^{3}\right]$

$\zeta \quad$ coefficient, which has to be determined experimentally (around 1)

A similar idea, increasing erosion resistance due increasing bed density, is expressed in the following equation from Mehta et al. (1994)

$$
\tau_{\mathrm{s}}=\alpha\left(\phi_{\mathrm{a}}-\phi_{\mathrm{ac}}\right)^{\beta}
$$

with $\quad \phi_{a} \quad$ volume fraction ( $1-n, n$ is the porosity of the sediment)

$\phi_{\mathrm{ac}} \quad$ critical volume fraction at the gel point, below which the soil has no measurable structural integrity and is thus not a bed but a fluid supported slurry 
$\alpha, \beta$ coefficients, to be determined experimentally, Mehta et al. (1994) proposed $\alpha=6.5$ and $\beta=1.6$

It is obvious that an experimental determination of the critical shear stress is almost inevitable. Since different modes of erosion exist (see above), different critical shear stresses need to be defined as well. The critical shear stress for surface erosion (or limit of particle movement) is determined by the aggregate shear strength or inter-particle bonds. Krone (1962) found aggregate strengths to be between 0.02 and $0.5 \mathrm{~Pa}$, which gives an idea of the order of magnitude of critical shear stress for surface erosion. Rheological tests, determining the flow curve and the yield strength of the soft sediment can give a good idea of these critical conditions (Otsubo et al. 1988).

For the determination of the critical shear stress for mass erosion (or limit of bed destruction) the bulk shear strength from standard soil mechanical tests can be used. Dense, consolidated clays have a parallel particle orientation (not a card house structure), therefore, the erosion resistance of those clays is less dependent on individual particle bonding but comes from the macroscopic strength of the material (Kamphuis et al. 1983). The critical shear stress for mass erosion, representing the resistance of a large number of aggregates, can be up to several $\mathrm{Pa}$. In a vane test, failure due to bulk erosion is simulated because the scale of the vane is much larger than the aggregates.

Amos et al. (1994) studied the effect of saltating sediment on the erosion threshold. They found that the so called "dynamic threshold" is lower than the static one and that the momentum transfer from the saltating clasts to the bed, induces shear stresses higher than the shear stress necessary to maintain erosion.

A more theoretical approach is based on the forces acting on the "particles" (aggregates, flocs). Starting from the forces acting on a cohesionless grain (see 2.2.1) an extra force $F_{c}$ needs to be included representing the net cohesive force. Including this cohesion in the force balance, equation (2.3) becomes (Mehta et al. 1994):

$$
\frac{\tau_{0}}{g\left(\rho_{s}-\rho\right) d_{c}}=\frac{\alpha_{3} \tan \phi}{\left(\alpha_{1}+\alpha_{2} \tan \phi\right)}+\frac{F_{c} \tan \phi /\left(\alpha_{1}+\alpha_{2} \tan \phi\right)}{g\left(\rho_{s}-\rho\right) d_{c}^{3}}
$$


The extra term can be represented as

$$
\frac{\tau_{s}}{g\left(\rho_{s}-\rho\right) d_{e}}
$$

with $\tau_{s}$ the shear strength of the cohesive sediment, which needs to be determined experimentally. When dealing with cohesive sediments the appropriate floc density has to be filled in equations $(2.35,2.36)$, which can be considerably smaller than the density of cohesionless grains.

Dade et al. (1992) proposed an expression for $F_{a}$ based on the yield stress $\tau_{y}$. The force $F_{a}$ is the adhesive force, it describes not only cohesion but it also includes organic binding or water-film tension, other mechanisms keeping the particles together in a natural mud. They assumed that the yield stress represents the average cohesive bond strength resulting from fine particle interactions in network structures. Hence, $F_{a}$ is defined as the yield stress multiplied by the surface area, $\mathrm{S}$, of an interfacial particle in effective contact with underlying particles:

$$
F_{a}=\tau_{y} S
$$

The following equation was proposed to calculate $S$, based on calculations for spheroidal particles:

$$
S=\frac{\pi d^{2}}{2}(1-\cos \phi) b_{2}
$$

with $d$ the primary particle size, $\phi$ the particle packing angle and $b_{2}$ a coefficient that incorporates the platiness of cohesive particles. This area $S$ takes into account the effects from relative protrusion of particles and from changes in effective contact surface area.

Another important remark to make is that due to the stochastic nature of turbulence and thus of the bed shear stress and due to the spatial variations in bed properties, the concept of critical erosion shear stress is not to be taken strictly. Even at bed shear stresses lower than the critical one limited erosion can take place due to the aforementioned factors. One way of introducing stochastics is through the velocities (see incipient motion of cohesionless sediments, $p$ 9). 
But also Partheniades (1965) proposed a stochastical analysis of erosion resistance. The shear stress is governed by the thickness of the laminar sublayer, which is always present near the bed. This thickness is not a constant, laminar sublayers are forming and disintegrating. Therefore the instantaneous shear stress can be presented as follows:

$$
\tau_{0}=\mu \frac{U_{0}}{\sqrt{\pi v t}}
$$

in which $U_{0}$ is turbulent velocity near the sublayer, $U_{0}$ varies randomly, therefore the variations of the shear stress are not periodical and also vary randomly. The shear stress can vary from a minimum, when $t=T(T=$ the period of growth of a sublayer $)$, to an infinite value as a maximum. Partheniades decided that it would be reasonable to assume a normal time distribution for the shear stress with a mean value calculated from the hydraulic conditions.

Partheniades' experimental results showed that the mechanisms for clay failure by surface forces are different from the failure by shear stresses applied through the mass of the soil. In the interior of a cohesive soil each particle is attached to at least two others, the whole structure is highly statically indeterminate. The resisting forces consist of the interparticle attractive forces and the individual particle strength. For mass erosion to occur one of these resisting mechanisms has to fail. At the surface the particles have at least one joint less with neighbouring particles. Also one of the particle's ends is free, hence, bending moments cause additional tensile stresses. So, the minimum particle bond rather than the average will govern the surface erosion phenomenon. The bond between clay particles is no constant but is in some way distributed between 0 and a maximum value, the average being $\bar{C}$. Therefore, for any applied shear stress at the surface of a cohesive sediment bed, there will always be clay particles whose bond will be small enough to be broken by that shear. Surface erosion is independent of the shear strength of the soil as long as the induced mass shear stresses are smaller than the average inter-aggregate bond. Hence an erosion criterion for surface erosion was developed as follows. Assuming that the hydraulic forces are equally distributed to all surface particles, the maximum tensile stress at each interparticle bond can be expressed as:

$$
\sigma_{\max }=\frac{k^{\prime} \tau_{0}}{N}
$$


in which $\mathrm{N}$ is the number of particles per unit surface area and $\mathrm{k}^{\prime}$ is a factor accounting for bending. Because of the small variations of $C$ compared to the spread of the shear stress, $C$ is considered to be constant. If the macroscopic strength $\mathrm{c}$ is caused by the bond $\mathrm{C}$ of $\mathrm{N}$ particles

$$
C=\frac{k^{\prime \prime} c}{N}
$$

with $\mathrm{k}^{\prime \prime}$ a constant.

Therefore the erosion criterion is

$$
\frac{\sigma_{\max }}{C}=k \frac{\tau_{0}}{c} \geq 1
$$

with $\mathrm{k}=\mathrm{k}^{\prime} / \mathrm{k}^{\prime \prime}$

And using a normal distribution for $\tau_{0}$, a probability for erosion at given hydraulic conditions can be calculated, provided the macroscopic strength $\mathrm{c}$ is known.

Erosion is mostly related to turbulent flow (turbulent bursts) but Mehta (1991) showed that cohesive sediment beds are usually smooth, i.e., small value of Re., so that a large viscous sublayer exists. Bond breakup will occur by torque due to viscous stresses, which in turn are due to the transfer of momentum across the boundary between sublayer and turbulent flow.

\section{Erosion rates}

Erosion rates for cohesive sediments are normally expressed as a function of excess shear stress above the critical value. Hence erosion rates are extremely sensitive to the definition of the threshold bed shear stress. When modelling field data, however, Lavelle et al. (1984) and Sanford et al. (1994) have obtained good modelling results using an erosion law without a critical shear stress. But, they believe that the concept of critical shear stress for erosion remains a viable one for thinking about the physics of the erosion process.

For soft beds (low density, strongly stratified, mostly the top layer of the bed) the following equation for surface erosion is put forward (Parchure et al. 1985): 


$$
E=E_{f} \exp \left\{a\left[\tau_{b}-\tau_{s}(z)\right]^{1 / 2}\right\}
$$

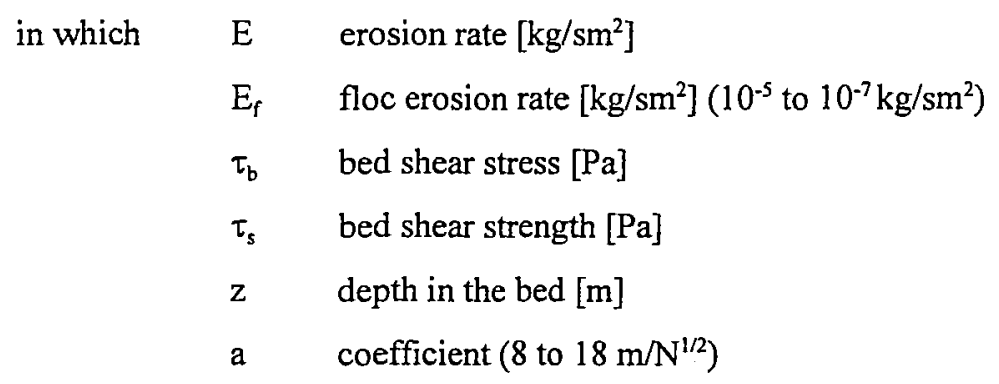

Equation (2.43) learns that even if $\tau_{b}=\tau_{s}(z)$, the erosion rate is still the floc erosion rate (very small) due to the stochastic nature of the erosion process.

Another approach, resulting from the observed temperature dependence of the erosion (coefficient "a" from equation (2.43) is inversely proportional to the temperature), is the application of the rate process theory. Originally developed for chemical reactions, this theory has been successfully applied to erosion phenomena as well (Parchure et al. 1985). The rate process theory provides a theoretical basis to explain the stochastic micro-level interactions between hydrodynamic and physico-chemical forces that are responsible for surface erosion (Mehta 1991). Flow induced shear deforms the aggregates at the bed surface, and if due to this process, all interparticle bonds connecting an aggregate to its neighbours are ruptured, the aggregate will be entrained. A bond is broken when a certain minimum or threshold bond energy is exceeded.

For more dense, uniform beds a first order approximation of equation (2.43) leads to

$$
\mathrm{E}=\mathrm{E}_{\mathrm{m}} \frac{\tau_{\mathrm{b}}-\tau_{s}}{\tau_{s}}
$$

with $\quad \mathrm{E}_{\mathrm{m}} \quad$ erosion constant $\left[\mathrm{kg} / \mathrm{sm}^{2}\right]\left(2.10^{-5}\right.$ to $\left.4.10^{-3} \mathrm{~kg} / \mathrm{sm}^{2}\right)$

In this case the bed shear strength (or critical shear stress) is considered to be a constant over the depth, ranging from 0.1 to $3 \mathrm{~Pa}$. The floc erosion rate as well as the erosion constant are a 
function of type of sediment, water content, total salt concentration, ionic species in the water, among others (Mehta et al. 1989).

However developed for surface erosion, equation (2.44) is also used as an approximate way to describe mass erosion, the erosion constant is then much higher $\left(E_{m}>2.10^{-3} \mathrm{~kg} / \mathrm{sm}^{2}\right)$. Mass erosion occurs for dense consolidated beds and/or at high excess shear stress (Mehta 1991).

The time dependency of the erosion depends on the bed structure. For uniform beds the erosion rates (at constant applied bed shear stress) are constant in time. Stratified beds show mostly an increase of erosion resistance with depth, therefore, at constant applied shear stress, the erosion rate decreases in time.

Amos et al. (1985, $1992 \&$ 1994) found two types of time dependency of the erosion, both in laboratory and field experiments. Type I-erosion characterizes initial bed failure. For small values of the excess shear stress the erosion rates decreased exponentially with time. For type Ia the decrease goes until zero erosion. In fact type Ia is a surface phenomenon and represents the suspension of small low density flocs or pellets which cover the bed. Type Ib is what was previously defined as surface erosion. The erosion rate decreases in time, but even at zero excess shear stress a small amount of material is still being eroded: the floc erosion rate. Type II-erosion is evident at greater depths in the sediment bed and the erosion rate is constant. Type II represents a continuous release of sediment once a critical shear stress, larger than for type $I$, has been exceeded. This behaviour resembles the previously described mass erosion.

Kusuda et al. (1982) showed the importance of shear stress history on erosion rates. Erosion rates at a certain constant shear are higher than when this same shear stress is reached after a stepwise increase of the shear stress. During the flow at lower shear stresses there is an increase in the solid fraction immediately below the bed surface. This hardening (rheopexy) is caused by particle reorientation. Also armouring can be important: selective erosion takes out fines of the bed surface and leaves the coarser grains.

Using the erosion criterion (equation (2.42)), Partheniades (1965) developed also an expression for the calculation of erosion rates. The rate at which the particles are being eroded per unit time, 
$\mathrm{dN} / \mathrm{dt}$, is proportional to the number of particles available for erosion, $\mathrm{Nr}$, and to the probability, Pr, that a particle will be eroded.

$$
\mathrm{Nr}=\frac{1}{\alpha_{1} \mathrm{~d}_{c}^{2}}, \operatorname{Pr}=\text { Probability }\left[\frac{k \tau_{0}}{c} \succeq 1\right]
$$

So

$$
\frac{d N}{d t}=\frac{1}{\alpha_{1} d_{c}^{2} t^{\left(\tau_{0}\right)}} \operatorname{Pr}
$$

in which $t^{\left(\tau_{0}\right)}$ is the time required for the breaking of a particle if condition (2.42) is fulfilled. If equation (2.46) is multiplied by the weight of an individual particle, $\rho_{s} g \alpha_{3} d_{c}{ }^{3}$ and the normal distribution of the shear stress is introduced, the erosion rate can be written as:

$$
E=\frac{\rho_{s} g^{\left(\tau_{0}\right)}}{t^{2}}\left[1-\frac{1}{\sqrt{2 \pi}} \int_{-\frac{c}{k \overline{\bar{\tau}_{0}} \eta_{0}}-\frac{1}{\eta_{0}}}^{\frac{c}{k \bar{\tau}_{0} \eta_{0}}-\frac{1}{\eta_{0}}} \exp \left[-\frac{w^{2}}{2}\right] d w\right]
$$

with $\bar{\tau}_{0}$ the average bed shear stress, calculated from the hydraulic conditions and $\frac{\bar{\tau}_{0}}{\eta_{0}}$ the standard deviation for the normal distribution of the shear stress. This equation still contains a lot of unknown constants which remain to be evaluated using experimental results.

\subsection{Mixed cohesive/non cohesive sediments}

\subsubsection{Occurrence}

Up to now cohesive and non cohesive sediments have been treated separately. The mechanisms responsible for the erosion of cohesionless sediments, dominated by size and specific gravity, are completely different from those provoking the erosion of cohesive material. The transport mechanisms of cohesionless sediments are relatively well understood, those of cohesive sediments have been studied extensively recently and are becoming better understood. Natural cohesive or cohesive-like sediments, that can be found in the estuarine environment or in 
combined sewers, are usually a mixture of coarse and fine material. Depending on the mixture composition a different erosional behaviour can be encountered. Hence, the transport mechanisms of mixtures require more research.

\section{A. Estuarine sediments}

Estuarine muds are generally a mixture of sand $(>63 \mu \mathrm{m})$, fines $(<63 \mu \mathrm{m})$ and organic material. Depending on the mixture composition and the bed structure the sand fraction can change the erosion and deposition characteristics of the mud significantly. So far most investigations have dealt with sand and mud separately because of their different physical properties.

An investigation on the distributions and characteristics of mud and sand mixtures occurring in the estuarine environment, by a review of literature and field surveys, was carried out by Williamson in 1991. Examples from all over the world show a wide range of mixture compositions: the sand fraction varies from a few percent up to almost only sand with a few percentage of fines. The bulk density of the sediments varies between 1100 and $1900 \mathrm{~kg} / \mathrm{m}^{3}$. Houwing et al. (1994) describe a field survey in the salt marches along the main coast of the Wadden Sea (the Netherlands). The sediments found there are a mud/sand mixture, containing 20 to $30 \%$ fines with a bulk density in the top layer between 1650 and $1800 \mathrm{~kg} / \mathrm{m}^{3}$. Amos et al. (1994) carried out erosion measurements with their Sea Carousel at the Manitounuk Sound estuary in the Hudson Bay, Canada. The sediments in the Sound are composed largely of silty clays, with a sand fraction between 5 and $60 \%$. The bulk density of the sediments varies between 1600 and $2000 \mathrm{~kg} / \mathrm{m}^{3}$.

Due to tidal action or storms the sediments are periodically suspended and afterwards deposited. This sequence of erosion and deposition results in many cases in a layered bed structure. Significant sediment sorting can occur due to different floc sizes or the presence of a sand fraction. Whether a layered bed results, depends on the suspended sediment concentration, the mixture composition, the sediment input rate, among others. But also flocculation, salt intrusion and the presence of plant material can enhance layering (Williamson 1991, Williamson et al. 1992, Edge et al. 1989). 
In the Scheldt river (Bastin 1974 and Schaeken 1994) sand/mud layers of up to $1 \mathrm{~cm}$ thickness can be found. The percentage fines varies between 30 and $80 \%$.

Along the Belgian coast, at the harbour of Zeebrugge, core samples were taken. Some of them show a highly stratified sediment bed (Plate 1) consisting of fine sand with mud layers in between. The reports about the drilling operations and the laboratory tests (Bestuur Geotechniek $1977,1978 \& 1979)$ mention an average mud fraction in the upper layers around $50 \%$ and an organic content of about $6.2 \%$. The bulk densities varied between 1.5 and $1.9 \mathrm{~kg} / \mathrm{dm}^{3}$.

In the literature review by Williamson (1991) several examples of stratified sand/mud mixtures are given. Although in most field surveys grab samples are taken so that the bed structure is not reported, some examples of core data can be found from which the three-dimensional features of mud and sand mixtures can be learned. In the Humber Estuary a vertical stratification of layers between 0.5 and $2 \mathrm{~cm}$ thickness is found; the mud content of the mixtures lies in between 2 and $20 \%$ mud. Also in the Severn Estuary laminated sediment beds were found. Other examples of layered sand/mud mixtures are given from Argentina and California. On the other hand, e.g., in Clyde, Scotland, consolidated and well mixed mud/sand mixtures were found. A homogeneous mixture is sometimes the result of bioturbation or reworking of the stratified sediments by organisms, mostly worms, feeding in the surface sediments.

\section{B. Sewer sediments}

Most of the research on cohesive sediment behaviour has focused on the esturarine environment. However, also in combined sewer systems cohesive-like sediments are present. Extensive studies on "real sewer sediments" over the past 5 to 10 years (Verbanck et al. 1994) have recognised that combined sewer deposits possess cohesive characteristics, although this cohesion primarily arises from agglutination due to tars and greases, chemical cementation and biological processes in the combined sewer rather than the classical concepts of electrostatic cohesion.

The commonest materials found in sewer sediments are grits, sands and other non cohesive particles, with a small amount of fines, usually less than $10 \%$. However, in combined sewers the organic content of the deposits can be as much as $87 \%$ (Wotherspoon 1994). The analysis of 
samples of sewer sediments from all over the UK have led to a classification of sewer sediments in 5 classes (Williams et al. 1989):

Type A coarse, loose, granular, predominantly mineral material found in the inverts of pipes

Type $B$ as $A$, but concreted by the addition of fat, bitumen, cement, .. into a solid mass Type C mobile, highly organic, fine grained deposits found in slack flow zones, either in isolated spots or above type A material

Type D organic pipe wall slimes an zoogloeal biofilms found in the invert of pipes without any other sediment deposit and around the mean flow level along the walls

Type E fine grained mineral and organic deposits found in storm sewer overflow storage tanks

The average physical characteristics of these sediments are given in Table 2.1.

Table 2.1: Physical characteristics of sewer sediment types (Williams et al. 1989).

\begin{tabular}{l|r|r|r|r|r}
\hline \hline $\begin{array}{l}\text { Sediment } \\
\text { type }\end{array}$ & $\begin{array}{r}\text { \% Gravel } \\
2.0-50 \mathrm{~mm}\end{array}$ & $\begin{array}{r}\text { \% Sand } \\
0.063-2.0 \mathrm{~mm}\end{array}$ & $\begin{array}{r}\text { \% Fines } \\
<0.063 \mathrm{~mm}\end{array}$ & $\begin{array}{r}\text { Bulk density } \\
\mathrm{kg} / \mathrm{m}^{3}\end{array}$ & $\begin{array}{r}\text { \% Organic } \\
\text { content }\end{array}$ \\
\hline Type A & 33 & 62 & 6 & 1720 & 7 \\
Type C & 0 & 55 & 45 & 1170 & 50 \\
Type D & 6 & 62 & 32 & 1210 & 61 \\
Type E & 9 & 69 & 22 & 1460 & 22 \\
\hline \hline
\end{tabular}

In most combined sewers the sediment bed consists of a thin, weakly organic layer (Type C) overlying a denser less organic layer (Type A). The top layer is a heavy but highly mobile suspension. It resembles the fluid mud layer encountered in estuaries, e.g., similar density. Different names have been proposed for this bed load layer: heavy-fluid layer (Verbanck 1992) or fluid sediment layer (Ashley et al. 1993), but up to now no accurate knowledge of its properties and behaviour exists. The layer is eroded at very low levels of shear stress and is responsible for about $12 \%$ of the total solids mass transported in dry weather flow. The erosion 
of this bed load layer could be contributing to the so called "first flush" and hence, represent a considerable pollution.

The sediments are predominantly coarse but rheological studies on sewer sediments (Williams et al. 1989, Wotherspoon 1994) have shown the elasto-viscous behaviour of combined sewer deposits with apparent yield strengths up to $2 \mathrm{kPa}$, much higher than cohesionless deposits. The high variation in yield stresses is due to differences in physico-chemical and biochemical properties. A strong correlation between yield stress and moisture content was found. The yield stress could also be related to void ratio and dry density (Wotherspoon 1994). Hence, sewer sediments exhibit rheological properties which are similar to those present in cohesive materials. After remoulding (e.g., after erosion) the sediments very rapidly recover their strength, when the bed densities are above a critical value of $1110 \mathrm{~kg} / \mathrm{m}^{3}$ (gel point) (Williams et al. 1989). Field studies have also demonstrated that the bed is highly stratified in density and strength. Therefore no good relation between yield stress and overall bulk density was found.

Kirby (1988) described sewer sediments as granuloviscous material, that can be modelled using a frictional pseudo-plastic model. An extensive set of rheological tests showed that the initial shear stresses increase with increasing normal stress, which indicates the granular properties of the material (friction). The steady state values of the shear stress are lower than the initial values, this softening is typical for viscous sediments.

As a conclusion, it can be said that combined sewers present all the problems of cohesive flocculant material when examining the suspended matter and an organic cohesive/non cohesive mixture when examining the bed deposit material (Wotherspoon 1994).

\subsubsection{Erosion of mixed sediments}

According to Mehta et al. (1994) the $20 \mu \mathrm{m}$ size is a good division between cohesive and non cohesive uniform sediments. Since natural sediments are mostly mixtures it is important to find out if these mixtures behave as cohesive sediments or not. Mehta et al. stated in 1989 that when large amounts of coarse detritus including sand, gravel and shells occurs with mud, the interactive behaviour between different sized sediments becomes quite complex and is not 
presently well understood. The present practice is to treat the coarse material separately from mud. However, recent studies already give some indications about mixture behaviour.

For coarse sand/clayey silt mixtures Murray (1977) found that the sand moves as bed load and the fines are transported in suspension. The necessary bed shear stress to obtain a given erosion rate increases with the percentage fines.

Kamphuis et al. (1983) found that for a higher sand content $(>20 \%)$ in a consolidated cohesive sediment bed, larger pieces of soil were eroded. The critical shear stress increases with clay content. The materials tested contained between 5 and $50 \%$ sand.

Van Rijn (1989) wrote that sand with a silt/clay content above $10 \%$ already shows a distinct increase of resistance against erosion.

Flume tests described by Collins (1989) showed that a small percentage of mud $(<10 \%)$ increases the resistance to erosion greatly. A small amount of cohesive particles in the bed causes a large reduction of the sand transport rate. Ripple heights are suppressed by the cohesive material, which acts as a binding agent for the sand particles. Two types of sand were used and the fine sand (125-250 $\mu \mathrm{m})$ showed higher critical shear stresses than the very fine sand (63$125 \mu \mathrm{m})$.

For estuarine sediments containing between 5 and $60 \%$ sand, Amos et al. (1994) found an increasing erosion resistance with increasing sand content, mainly due to the increasing bulk density of the sediments.

Flume experiments by Panagiotopoulos et al. (1995) both in uniform flow and under wave conditions showed an increasing erosion resistance of sand with increasing mud content; the finer the sand, the higher the critical shear stress for erosion. The increase is stronger when the mud content is higher than $30 \%$. Also the liquid limit of the sediment mixture increases significantly when the mud content rises above $30 \%$. Both effects indicate a change of internal sediment structure at circa $30 \%$ mud in the mixture.

Teeter (1994) did laboratory tests on mixtures of silt and kaolinite and on a natural mud. He found that the erosion of mixed sediments is size dependent: at low shear stresses the finer fraction seems to be washed out, at higher shear more and more silts are being eroded. 
Ockenden et al. (1988) carried out carousel erosion tests on mud beds with 0 to $66 \%$ sand added to the top layer. In most experiments mass erosion occurred with lumps of material being removed from the bed. An increasing sand content resulted in higher densities and increasing erosion resistance. The sand also reduced the amount of erosion for a given bed shear stress. Also reversing flume erosion tests by Williamson et al. (1992) indicated increasing erosion resistance for increasing sand content. Although inhomogeneities in the sediment bed were the main cause for the onset of erosion.

Deployment of ISIS (Instrument for Shear strength In-Situ) in the Severn estuary (Williamson 1993) showed a strong correlation between critical shear stress for erosion and bed density. The erosion resistance increases for increasing bed density, whether this density increase is caused by increasing sand content or consolidation.

Chesher (1994) developed a model for mixed sediments using Collins data (1989) and ISIS field data. The model uses the following assumptions: increasing sand content increases the consolidation rate of the mud; increasing sand content increases the shear strength of the mud (by increasing the density); increasing sand content decreases the erosion rates of the mud; once in suspension sand and mud act independently; deposition of sand and mud is independent. The model is based on an erosion rate equation like equation (2.44) in which $E_{m}$ and $\tau_{c r}$ are a function of the sand content: the critical shear stress increases linearly with sand content to a maximum and then decreases to the sand value. The erosion constant decreases linearly from its mud value to zero at only sand. Simulations with the model were done with and without including interactions between the two sediment fractions. The results showed large differences between both simulations, indicating the importance of the interactions.

Willis et al. (1994) constructed a numerical model for mud and sand erosion and deposition. From field tests he derived that $20 \%$ mud in the mixture is the boundary between sand and mud behaviour.

The erosion of sewer sediments is described as continuously body erosion by the removal of large pieces of the bed, similar to the turbulent bursting in estuarine environments (Ashley et al. 1992). A surface erosion phenomenon has not been encountered. This bulk erosion starts at shear stresses around $2 \mathrm{~Pa}$ during dry weather flow conditions. The dry weather flow erodes only the surficial layer of the bed and causes the formation of a moving bed load layer described as 
"heavy fluid layer" (Verbanck et al. 1994) or "fluid sediment" (Ashley et al. 1993). The layer quickly redeposits when the shear stress decreases and rapidly regains strength.

In storm conditions bed shear stresses, higher than 4 to $6 \mathrm{~Pa}$ lead to the complete erosion of the upper layers of the sewer deposit (Wotherspoon 1994).

Wotherspoon (1994) developed a model to predict the erosion of cohesive sediments in a combined sewer. The model assumes that erosion occurs when the bed shear stress exceeds the yield stress of the sediment. The bed is represented in several layers with increasing density and decreasing water content. Using the experimentally developed relation between yield stress and moisture content (equation (2.32)) the erodible depth can be calculated. This model indicates that only the less dense ( 1085 to $1370 \mathrm{~kg} / \mathrm{m}^{3}$ ) surficial layers will be eroded.

Alvarez (1990) studied the influence of cohesion on sediment movement in sewers. In a laboratory study he used Laponite clay/sand mixtures as a synthetic sewer sediment. These mixtures showed a similar rheological behaviour as real sewer sediments (Williams et al. 1989). The critical shear stress for erosion increased with increasing clay content up to a maximum and then decreased. The maximum erosion resistance was around 6 to $7 \mathrm{~Pa}$ corresponding to clay contents between 20 and $40 \%$ clay. The erosion starts with isolated spots and increasing the bed shear stress again, causes a rapid collapse of the bed. A cohesive behaviour is noticed for Laponite contents higher than 5 to $15 \%$ depending on the sand size. At these clay contents all sand particles are wetted by the clay suspension and hence, cohesion can develop. Once eroded the sediment disintegrates and is transported as individual cohesionless particles. The cohesive additive slightly reduces the transport capacity of the flow.

\subsection{Summary}

The literature review on sediment transport in uniform flow has shown that both for cohesive and non cohesive sediments a number of satisfying (empirical) transport equations exist. Each of these models has a limited range of applicability (e.g., grain size, bed density) and needs a lot of coefficients that have to be determined experimentally. The performance and accuracy of the formulas depends on the choice of these coefficients. However, most of these equations have successfully been used in a number of practical applications. 
For the onset of erosion the picture is less clear, especially for cohesive sediments, where the critical shear stress for erosion depends on many properties of both the sediment and the eroding fluid. Moreover, incipient motion conditions cannot be determined exactly since the bed shear stress and the sediment properties vary stochastically in time and space. Therefore, a probabilistic approach, calculating the probability for erosion at the given hydraulic conditions, seems more appropriate. Although the definition of a critical bed shear stress remains useful for solving many practical problems.

Natural sediments are mostly a mixture of cohesive and non cohesive sediments and the behaviour of those mixtures is currently not well understood. Especially concerning the influence of mixture composition on erosion resistance and mode of erosion contradicting findings have been reported. Therefore, an extensive laboratory research is started to investigate the erosional behaviour of partly cohesive sediments. 


\section{Chapter 3: Experimental study}

\subsection{Introduction}

The physical processes related to the erosional behaviour of partly cohesive sediments are currently not very well understood. The previous chapter clearly identified the need for further experimental research on mixed sediments. In fact, even when applying existing mathematical models for the erosion and transport of cohesionless or cohesive sediments, a number of parameters and coefficients remain to be determined experimentally.

Due to the complex nature of the physical processes, laboratory research seems appropriate to study the erosion of sediment mixtures in detail. In laboratory circumstances the influence of one or more parameters can be isolated, while all other variables remain constant. In the field the different influences can never be completely separated. Of course laboratory experiments cannot represent the natural processes completely, field and laboratory studies are both essential. Laboratory work is ideal to get detailed information on some specific aspects of a problem and to develop relations between the different parameters involved, that can be used in mathematical models. Field surveys can be used to validate laboratory based theories, to study the behaviour of undisturbed sediments and to assess a range of parameters influencing the erosion of the sediment bed in a certain region.

As explained in Chapter 1, the study of the erosion of partly cohesive sediments was started in the framework of an interuniversity F.K.F.O.-project. Hence, the results of these laboratory experiments in a straight rectangular flume could be compared with other laboratory data (flume with a semi-circular cross section) and with field data from joint measuring campaigns. Moreover, participation in the European MAST2 G8M Coastal Morphodynamics-programme, Project 4: Cohesive Sediments, gave access to even more lab and field data, which resulted in a wide range of data to check and validate the author's experimental findings. 
In the following paragraphs the flume, the measuring-instruments and the sediments used will be described. Also an overview will be given of the experimental procedure and the data processing techniques.

\subsection{Experimental flume}

The flume in the Hydraulics Laboratory of the Katholieke Universiteit Leuven is about $9 \mathrm{~m}$ long. It is a straight flume with a closed recirculating water system, this to prevent the fine sediments from entering the main water supply system of the laboratory. The flume, mainly made out of wood and supported by a steel structure, can be tilted to a slope of maximum $4 \%$. The bottom slope is measured with a hypsometer. The rectangular cross section is $40 \mathrm{~cm}$ wide and $40 \mathrm{~cm}$ deep. Figure 3.1 gives a side view of the construction.

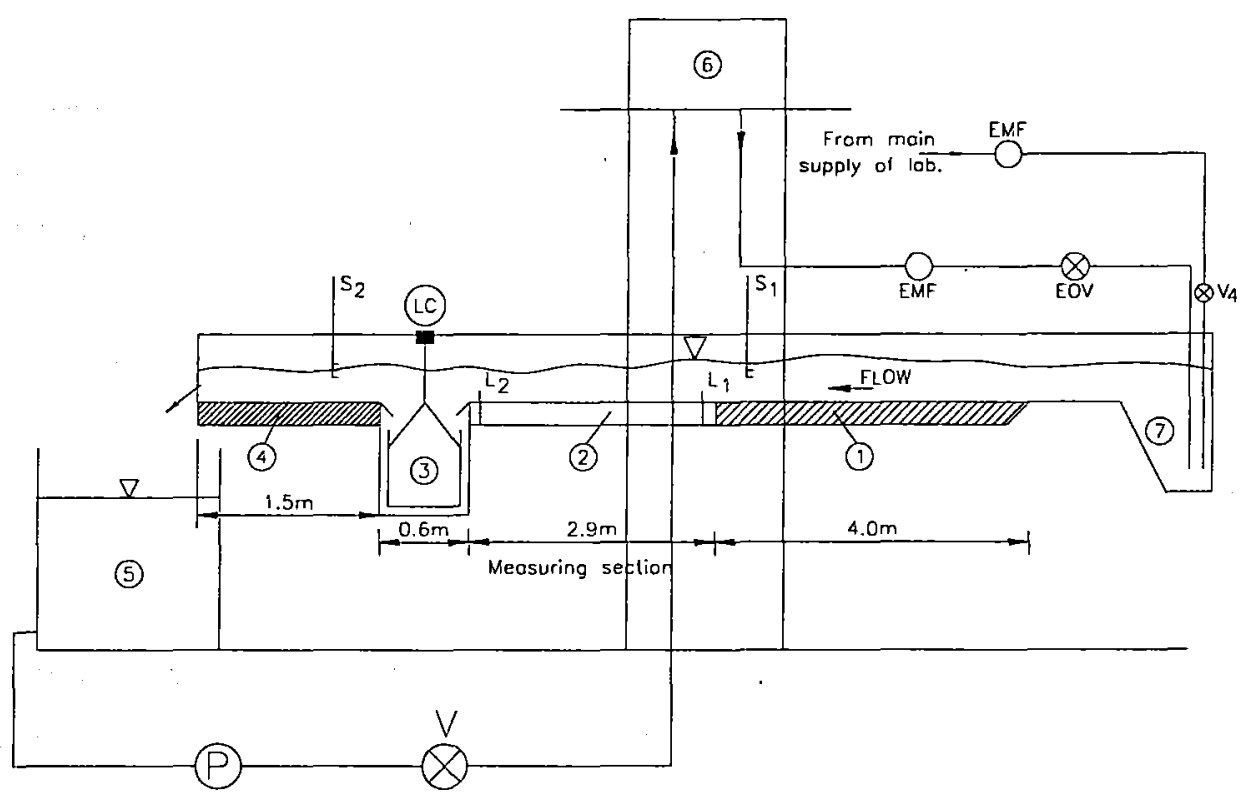

Figure 3.1: Side view of the rectangular flume. 
Water is pumped ( $\mathrm{P}=$ pump, $\mathrm{V}=$ valve, Figure 3.1) out of a large downstream reservoir (5) into an overhead tank (6). This tank was mainly built for the generation of hydrographs (Sediment transport in unsteady flow, Kabir 1993). From there the water flows through the flowmeter (EMF) and an electrically operated valve (EOV), used for discharge regulation, into the upstream reservoir (7) and then into the flume.

The shape of the transition from the reservoir to the flume was designed to still the water coming from the overhead tank. The first $4 \mathrm{~m}$ of the flume is the inflow region (1). This section has a rigid, wooden bottom (false bottom: $8 \mathrm{~cm}$ thick) and its aim is to provide a fully developed turbulent flow in the next section. This next part is $2.9 \mathrm{~m}$ long and is the measuring or sediment section (2). The sediment is placed in a steel removable box, covering the whole width and length of the sediment section. The sediment box is $8 \mathrm{~cm}$ deep, so that the sediment bed is flush with the rest of the flume. These removable sediment boxes allow a quick succession of different experiments. The measuring section also has glass walls on one side so that visual inspection of the bed and the erosion processes is possible. Downstream of the movable bed a sediment trap (3) is constructed. The length of the trap is $0.60 \mathrm{~m}$. The sediment trap collects the bed load. In fact in all the experiments the definition of bed load is the total amount of sediments caught by the sediment trap. The last part of the flume is the outflow section (4). This $1.5 \mathrm{~m}$ long zone with a wooden false bottom (similar to the inflow region) prevents the flow from being completely disturbed by the sediment trap. Experiments with colour dye have shown that only the bottom streamlines ( 1 to $2 \mathrm{~cm}$ ) dive into the trap, all others go straight over it, without being influenced by the presence of the sediment trap. A tail gate at the end of the flume can be used to regulate water levels and/or to close the flume during bed formation and consolidation.

An extra water supply from the main laboratory system is available. This can be used to fill up the flume before an experiment. In this way the sediment bed can consolidate under water and the water layer prevents the destruction of the sediment bed by the sudden start of the pumps.

The flume, as described above, has some disadvantages. Due to the limited width, secondary currents will be relatively important (see Chapter 5). The limited length of the flume causes doubts as to the possibility that fully developed flow can occur. And the limited length of the sediment bed will cause some end effects, due to the abrupt transition from rigid to movable bed. 
The water supply system with the large downstream reservoir and the pumps also creates some extra problems. In the case of flocculated, cohesive sediments in suspension, the pumps will destruct the flocs. In the large downstream reservoir the large sediment particles will settle (but most of them already fell into the sediment trap) and the suspension, flowing back into the flume, will be diluted.

As an answer to some of these problems, in the last two decades annular flumes have been used for cohesive sediment transport research (Mehta et al. 1979, Ockenden et al. 1988, among others). An annular flume has a continuous section and the flow is generated by the rotation of the roof or by the rotation of the roof and the bottom (MAST 1993), in other words without pumps that can disrupt flocs. Recent studies on the flow structure in an annular flume, however, have created some doubt about the use of carousel flumes. Sheng (1989) showed that radial velocities in an annular flume can be up to $20 \%$ of the mean azimuthal velocity and $50 \%$ of the near bottom azimuthal velocity. This means that sediments can be entrained not only by tangential bed shear stresses but also by radial stresses and that erosion laws relating sediment in suspension to azimuthal shear stresses often contain non-negligible errors. Booij (1994) carried out detailed measurements of the flow field in a rotating annular flume and concluded that secondary velocities never become much smaller than the fall velocities of fine sediments. This means that the use of a carousel flume for deposition studies is limited. On the other hand he concluded that an annular flume is well suited for erosion studies, but that the turbulence pattern is very different from the turbulence pattern in rivers or channels, which limits the usefulness of the carousel as a model for free surface flow.

Hence, a straight flume does not seem to be a bad choice after all. The free surface flow will resemble the natural flow patterns in rivers and channels more closely. And some of the problems described earlier can be solved with certain measurement- or data processing techniques. The influence of the walls is accounted for by the calculation of the bed shear stress using a side wall elimination technique (Appendix 1). By an appropriate sampling method the dilution of the suspended sediment is incorporated in the calculations. The disrupting of the flocs by the pumps is not important, since the aim is to study erosion and not deposition. And the end effects can be diminished -but not eliminated- by a careful placement of the sediment bed. 


\subsection{Measurement techniques}

Before, during and after each experiment measurements are made to characterize the sediment bed (mixture composition, density, water content), to find out the hydraulic conditions of the test (water level, discharge and velocities) and to follow the erosion processes (bed load, suspended load, bed forms). Water levels, point velocities, discharge and cumulated bed load are recorded by a computer, through a data-acquisition system. All the other measurements are made by hand.

\subsubsection{Water level}

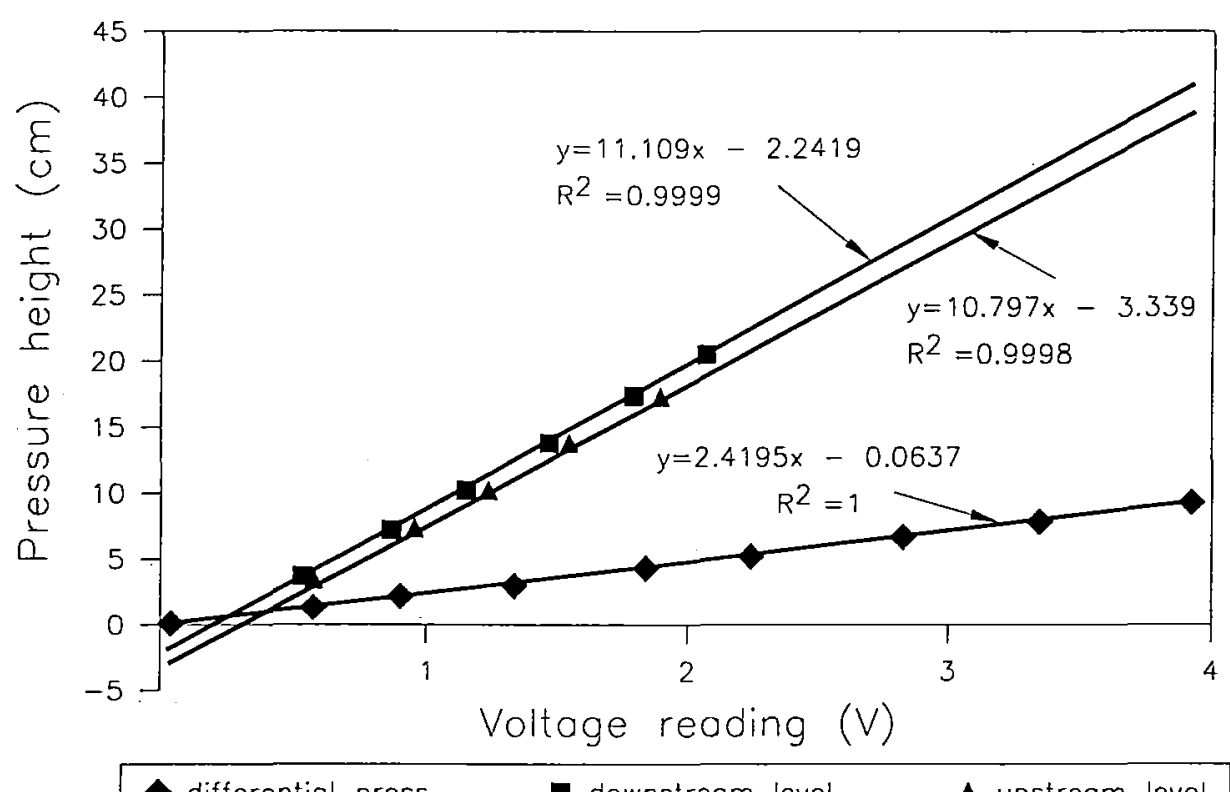

differential press.

downstreom level

A upstreom level

Figure 3.2: Calibration of the two static pressure transducers (water level upstream and downstream) and the differential pressure transducer (flow velocity).

Water levels are continuously measured with 2 pressure transducers (Druck PDCR 830, range $70 \mathrm{mbar}$ or $70 \mathrm{~cm}$, non-linearity and hysteresis $0.1 \%$ of full scale) connected to the flume bottom: immediately upstream (L1, Figure 3.1) and downstream (L2) of the sediment reach. The pressure transducers are connected to holes made in the sediment box, at the level of the sediment 
surface. The transducers are not only connected to the flume bed but also to a set of calibration columns. In this way regularly a calibration formula can be developed that links the output voltage, recorded by the computer, to the water level in the flume. An example of the calibration results is given in Figure 3.2. Typically regression coefficients around 0.999 are found, indicating the almost perfect linearity of the calibration formula.

\subsubsection{Velocity}

During the first, preliminary experiments velocities were measured with a micro propeller. The velocity of the flow is measured by measuring the rotational speed of the propeller. This technique however does not allow point measurements. The propeller integrates the velocities over its diameter, which is $1.5 \mathrm{~cm}$, and hence, getting close to the bottom is impossible. Since detailed measurements of the velocity profile can be used to calculate shear stresses, point velocity measurements near the sediment bed are important.

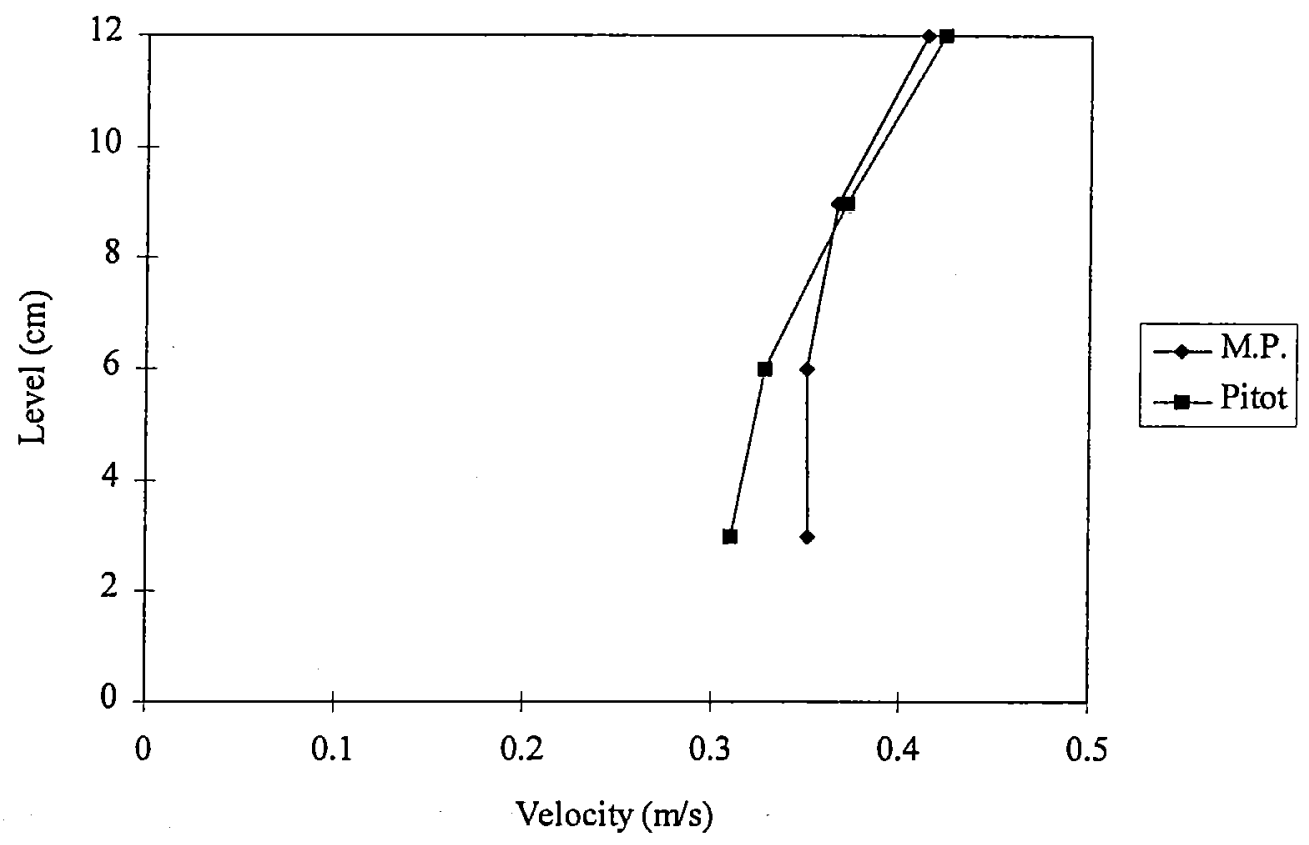

Figure 3.3: Comparison between velocities measured by the micro propeller (MP) and the pitot tube. 
Therefore, a pitot tube connected to differential pressure transducer ( Schaevitz P-3091, range 0 to $12.5 \mathrm{mbar}$, i.e., $12.5 \mathrm{~cm}$ or $1.5 \mathrm{~m} / \mathrm{s}$; non-linearity and hysteresis $0.5 \%$ of full scale) is used in all further experiments. The external diameter of the pitot tube is only $3 \mathrm{~mm}$ so that measurements can be taken at a distance of only $2 \mathrm{~mm}$ from the bed, without disturbing the flow or the sediment surface too much. The pitot tube is mounted on a point gauge and can be moved over the complete width, depth and length of the flume. A set of calibration columns makes the measuring device complete. A typical example of the calibration results is given in Figure 3.2. Again the regression coefficients indicates the reliability of a linear calibration formula. In Figure 3.3 a comparison is made between velocities measured with the micro propeller and with the pitot tube. Close to the bottom the two instruments give significantly different results. This is the result of the integrating effect of the micro propeller. Near the bed the velocity changes with depth are the biggest, hence, averaging over $1.5 \mathrm{~cm}$ will cause the highest errors there.

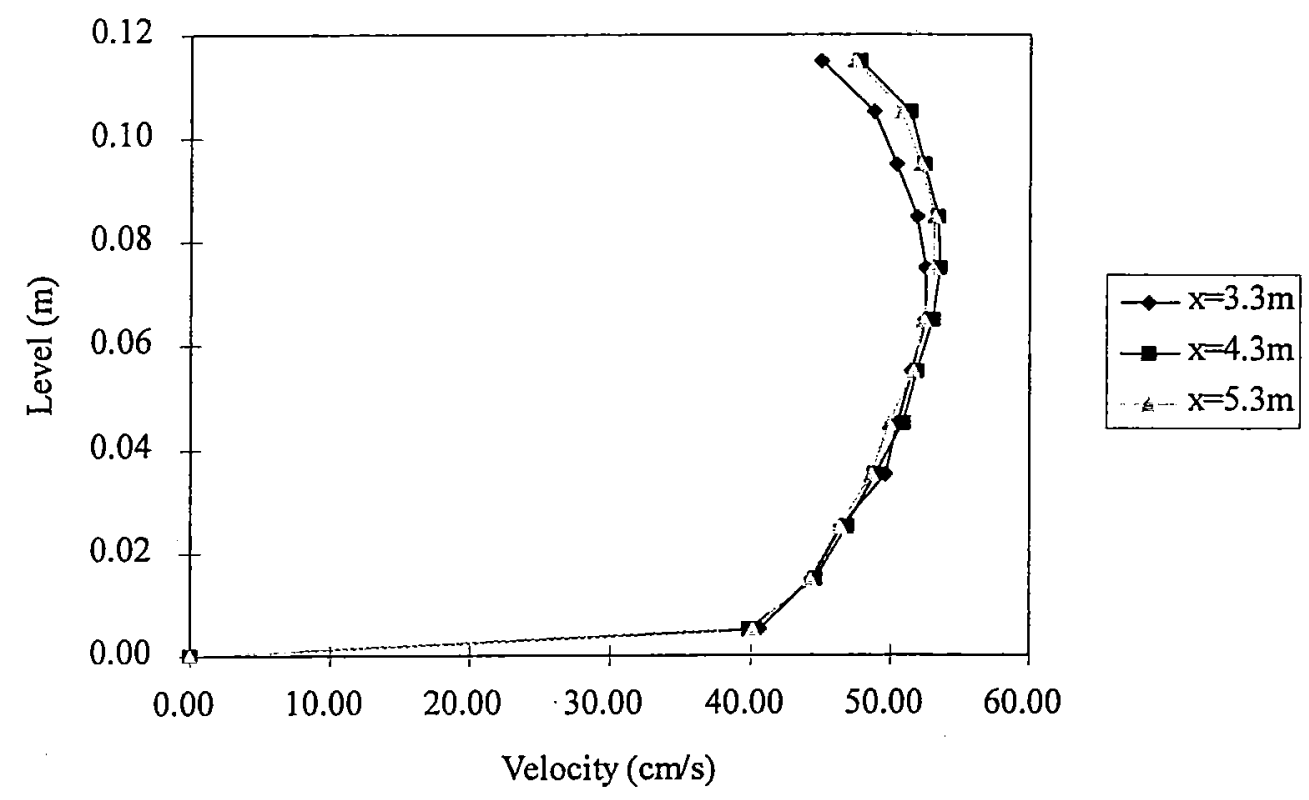

Figure 3.4: Velocity profiles measured at different positions along the length of the flume.

In most of the runs only one velocity profile is measured along the mid vertical of the cross section and half way between the two water level measurement points. Preliminary tests showed that the velocities are quite uniform over the total length of the bed. In Figure 3.4 velocity 
profiles measured at different locations along the flume (with fixed bed over the total flume length) are plotted. The $x$ coordinate gives the position along the flume axis, starting from the upstream reservoir. The measured velocity profiles are almost identical. Figure 3.5 gives a comparison of a velocity profile measured above the fixed bed upstream and a profile measured above a sand bed, the sediment reach is situated between 4 and $7 \mathrm{~m}$ from the upstream reservoir. The two profiles do not differ significantly. Half way the sediment reach, the transition from fixed to movable bed will certainly no longer be noticeable in the velocity profiles. In other words velocity profiles measured there or further downstream do not differ significantly. The position in the cross section (i.e., the distance from the side walls), however, is quite important due to the influence of the walls, as later detailed measurements will show (see Chapter 5).

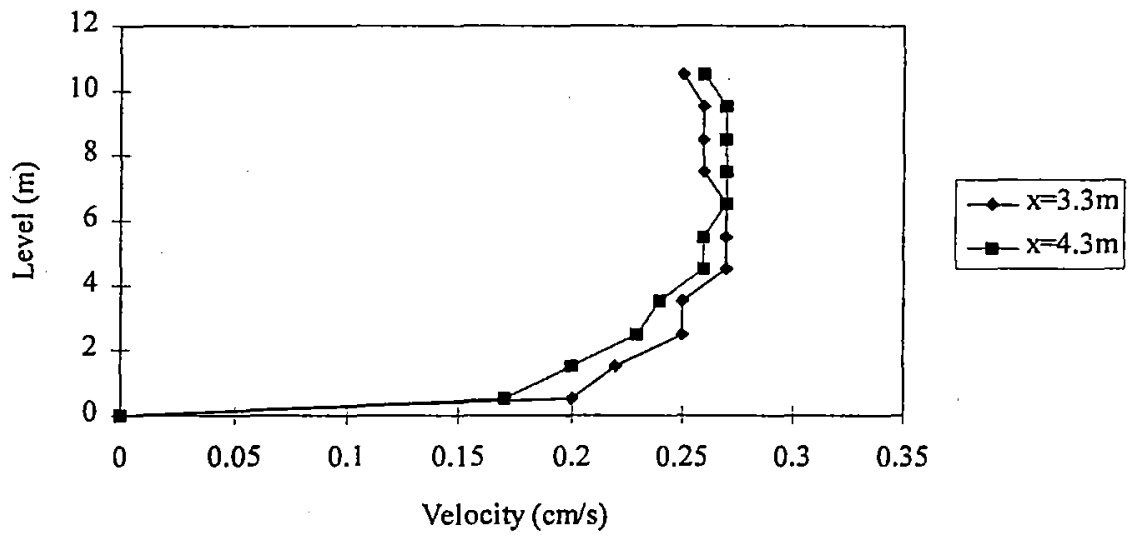

Figure 3.5: Comparison between a velocity profile measured above the fixed bed $(x=3.3 \mathrm{~m})$ and a profile measured above a sand bed $(x=4.3 \mathrm{~m})$.

\subsubsection{Discharge}

The discharge through the flume is measured with a Kent-Veriflux electromagnetic flow-meter (EMF, Figure 3.1). This device is mounted in a horizontal piece of the inlet pipe, between the overhead tank and the upstream reservoir. The output signal goes into the computer and is previously calibrated, so that the discharge is displayed in $1 / \mathrm{s}$. Another similar flow-meter is installed to measure the discharge coming from the main supply. 


\subsubsection{Bed load}

As mentioned before, all the sediment falling into the sediment trap is considered to be bed load. The sediment trap consists of two parts: an outer box, connected to the flume and an inner box, that is a little smaller, hanging free on a steel cable. A funnel leads the sediment into the smallest box. This box is, through the cable, connected to a load cell (Interface, SM 1000; LC, Figure 3.1). The maximum possible weight is $500 \mathrm{~kg}$, with a non-linearity and hysteresis error of about $0.05 \%$ of the full scale. Since both boxes are filled with water, the load cell measures the cumulated under water weight of the sediments in the trap. The load cell was also calibrated so that the output voltages, measured by the data-logging system, can be converted into dry sediment weights.

\subsubsection{Suspended load}

To determine the concentration of material in suspension, samples are taken and examined afterwards by filtration (Millipore filters, $5 \mu \mathrm{m}$ ). The accuracy of the used analysing procedure is about $0.5 \mathrm{mg} / \mathrm{l}$. At predefined time steps a sample is taken just upstream of the sediment reach (S1, Figure 3.1) and at the same time immediately downstream of the sediment trap (S2). The samples are taken by gravitational suction. The upstream sample represents the concentration pumped around in the system, diluted by the water in the reservoirs (background concentration). The downstream sample contains the material in suspension after the bed load has settled out. The difference in concentration between both samples gives an idea about the amount of suspension due to erosion of the sediment bed. Measured concentrations are never so high that the suspension would get saturated and limit further erosion. Hence, dilution of the suspension, by the large downstream reservoir, does not affect the erosional behaviour under study.

Since preliminary experiments have shown that, considering the accuracy of the sediment concentrations, the concentration profile of the mostly fine suspended sediments is fairly uniform over the depth and width of the cross section (Figure 3.6), no concentration profiles are recorded but point measurements are taken at mid-depth and -width. 


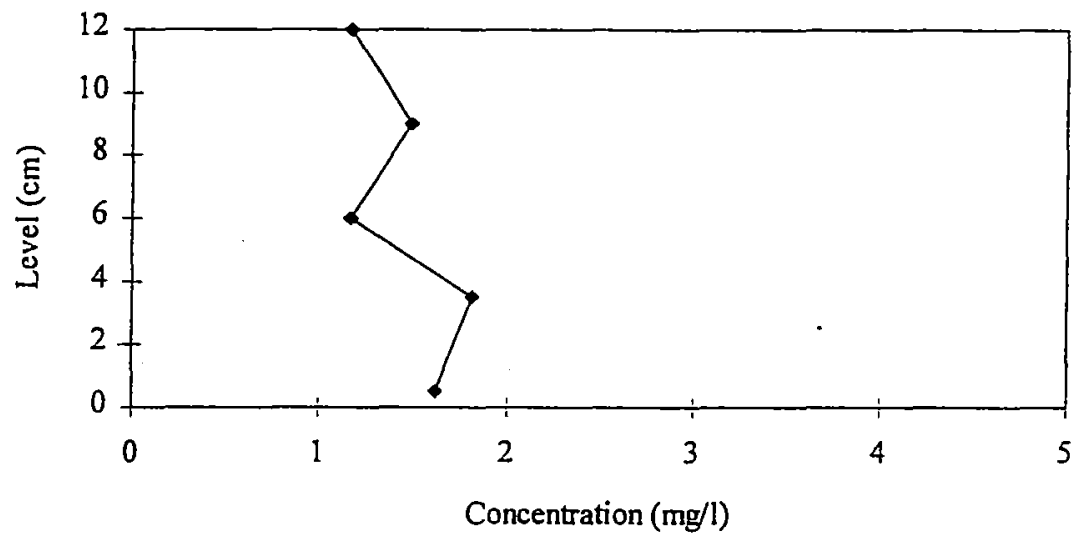

Figure 3.6: Measured concentration profile above a montmorillonite mixture.

Taking samples and analysing them is a time-consuming activity, therefore the number of samples is limited to one sample each 15 minutes. This procedure limits the information on suspension concentrations compared to the "continuous" measurements of most other parameters. Another disadvantage of this procedure is that while the experiment is running, no information on the suspension concentrations is available and hence there is no way of knowing whether an equilibrium state has been reached or not.

\subsubsection{Bed density}

Depending on the bed structure, two methods are used to determine the bed density. For a homogeneous bed, a sample with known volume of the bed material is taken after each experiment (destructive test) and weighed. The accuracy of the density measurements is $0.05 \mathrm{~kg} / \mathrm{dm}^{3}$. This method gives the mean bed density after the experiments. It is assumed that this density does not differ significantly from the density at the start of the experiments because the sediment bed has already consolidated for one night before the start of each experiment and because the duration of an experiment is relatively short.

As an example, the measured water content of a homogeneous montmorillonite mixture before the test was $31 \%$, after the test the same bed contained $29 \%$ of water. The difference between 
these two water contents (and hence the density) is partly caused by consolidation and partly by measuring errors and inhomogeneities. For some experiments on low density mixtures, the erosion test starts without a consolidation period. In these cases, consolidation is likely to occur during the test and the density measured afterwards is not completely significant for the bed density at the start of the erosion experiment.

For the experiments with deposited beds, the sediment bed is very stratified and taking a bulk sample is not an appropriate technique. Therefore, the bed formation process is carried out simultaneously in the flume and in a settling column (see further). With a gamma-densimeter the bed density profile in the column can be measured at the start of the erosion experiments. The gamma-densimeter consists of a radio-active source and a detector, placed at the other side of the column, measuring the amount of gamma-rays passing through the column. The principle of the apparatus is that a sediment mixture absorbs more gamma-rays with increasing sediment density (MAST 1993). The accuracy of the instrument is about $3 \%$ or $0.03 \mathrm{~kg} / \mathrm{dm}^{3}$. After calibration for a certain sediment type (in combination with the settling column), the probe can be used to make non-destructive density profile measurements, showing clearly the stratified structure of the sample.

\subsubsection{Mixture composition}

Another sample of the bed material is taken to determine the exact mixture composition. The sample is oven dried to measure the water content and afterwards wet sieved on $63 \mu \mathrm{m}$. The fraction above $63 \mu \mathrm{m}$ is the sand fraction. The \%fines is defined as the percentage by weight of the dry sediment mixture finer than $63 \mu \mathrm{m}$.

For the homogeneous sediment beds, a sample of the sediment mixture is taken after each experiment. For the stratified, deposited beds, a sample of the input slurry is analysed. 


\subsubsection{Erosion patterns}

The erosion patterns and bed forms, developing during an erosion experiment, can be visually observed through the glass walls at the measuring section. The dimensions are measured using a point gauge, that can be moved over the total length and width of the sediment region.

\subsection{Sediments}

During the experiments 5 types of cohesive material and 1 type of fine sand are used to make the different mixtures. The grain size distribution curves of these sediments are given in Figure 3.7.

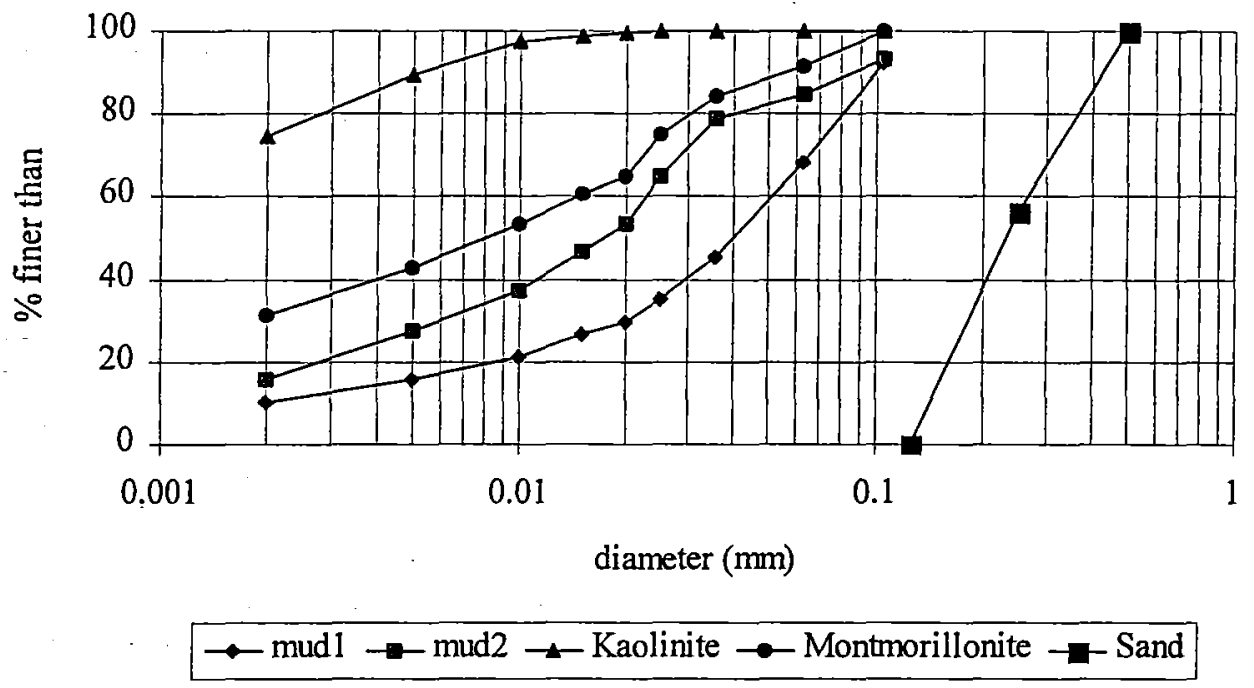

Figure 3.7: Grain size distribution of the used sediments. The grain size distribution of the sand is established by sieve analysis. For the cohesive sediments, the grain sizes are determined by measuring the settling velocity of the sediment in a small column.

The sand is a uniform fine white quartz sand from $\mathrm{Mol}$. The mean diameter is around $0.23 \mathrm{~mm}$. The sand itself contains no particles smaller than $63 \mu \mathrm{m}$. This means that all the fines in a mixture come from the added cohesive sediments. In the first set of experiments two types of clay were used as "artificial" cohesive material: kaolinite (China clay) and a brown pottery clay, that mainly consists of montmorillonite. These clays contain no organic material and hence, some 
problems related to the presence of organic matter are eliminated. Later, sediment mixtures are made using "natural" muds. These real muds come from three places in the river Scheldt, near the Antwerp harbour. Previous studies (Laboratorium voor Hydraulica 1983) showed that the clay fraction of Scheldt mud typically contains smectite (30\%), illite (55\%) and kaolinite (15\%). Mud1 is from an intertidal zone. The natural sand content is $33 \%$, it has an important organic fraction (7\%), including worms, and an almost black colour. Also mud3 is probably intertidal mud (no grain size analysis of mud3 exists, but the sand content is about $38 \%$ ). Mud3 is very dark and contaminated with oil. The content of organic material is around $6 \%$ and it contained rather coarse particles. Mud2 is from a subtidal region. The natural sand content is only $15 \%$, the content of organic matter is $10 \%$ and its colour is more brown.

As shown in Figure 3.7 only the kaolinite has no sand fraction, i.e., the fraction larger than $63 \mu \mathrm{m}$. All the other cohesive sediments mixed with the fine sand will result in a more graded mixture, whereas the kaolinite mixtures will consist of two separate fractions.

Table 3.1: Composition of the sediment mixtures.

\begin{tabular}{l|r|r}
\hline \hline Type of experiments & Type of cohesive sediment & Amount of fines in the mixture \\
\hline & Montmorillonite & $0 \rightarrow 28 \%$ \\
China clay & Mud1 & $0 \rightarrow 15 \%$ \\
1.65 or $1.85 \mathrm{~kg} / \mathrm{dm}^{3}$ & Mud2 & $6,10 \%$ \\
& Montmorillonite & $0 \rightarrow 14 \%$ \\
\hline & China clay & $45 \%$ \\
Deposited layered bed & Mud2 & $50 \%$ \\
& Mud3 & $70 \rightarrow 82 \%$ \\
\hline \hline
\end{tabular}

With these sediments a great number of mixtures are made. An overview of the mixture compositions used in the different experiments is given in Table 3.1. An explanation on the two different types of experiments is given in the next paragraph. 


\subsection{Two types of experiments}

Two types of erosion experiments are carried out, which differ only in the preparation of the sediment bed. The erosion experiment itself is ways performed according to the same procedure, as explained in the following paragraph.

The first type of experiments are erosion tests on homogeneous placed beds. The aim is to look at the transition in erosional behaviour from cohesionless to cohesive mixtures. Therefore, the amount of fines is gradually varied between $0 \%$, only sand, and $30 \%$ (Table 3.1 ). For these experiments a uniform mixture of sand, cohesive sediment and water is prepared outside the flume and then placed (poured or shovelled, depending on the density) in the sediment box. The bulk density of most mixtures is kept constant around $1.85 \mathrm{~kg} / \mathrm{dm}^{3}$. The consolidation time for those mixtures is one night. Some experiments were carried out at a bed density of $1.65 \mathrm{~kg} / \mathrm{dm}^{3}$, a typical density for type A sewer sediments (see Chapter 2). Then, the experiments start straight after mixture preparation, because consolidation would increase the density significantly and maybe cause some segregation as well.

The second type of erosion experiments is done on deposited layered beds. The sediment bed is formed inside the flume (see further) by deposition in still water. A mixture slurry of very low density is prepared and allowed to settle out into the sediment box. As a result the sediment bed will be stratified. In these experiments the erosion mechanisms of layered sediment beds (e.g., tidal rivers, estuaries) are studied and the influence of the sand content on the erosional behaviour is investigated. For the experiments on deposited beds the \%fines varies from 40 to $80 \%$ (Table 3:1).The density in the deposited beds is much lower (around $1.1 \mathrm{~kg} / \mathrm{dm}^{3}$ ) and varies with the depth. The experiments usually started half a day after the last layer was added.

\subsection{Experimental procedure}

For the experiments with homogeneous mixed sediments, the necessary amounts of sand, cohesive material and water are weighed and then mechanically mixed for a sufficiently long 
time so that a uniform mixture results. An approximate mixture composition can be determined in advance, but, due to the lack of accuracy of the balance, a more exact mixture composition has to be determined on a sample after the experiments. The mixture is placed in the flume, levelled with a steel plate, flush with the upstream false bottom, and left to consolidate over night under a water layer.

For the deposited bed tests some changes to the experimental flume have been made. A settling tank, $3 \mathrm{~m}$ long, $0.40 \mathrm{~m}$ wide, $1 \mathrm{~m}$ high is constructed, this tank can be mounted on the sediment box in the measuring section. In this way a slurry can be pumped into the tank and is allowed to settle in the sediment section only.

A $1 \mathrm{~m}$ high, $0.10 \mathrm{~m}$ diameter perspex settling and consolidation column is also used. In this column the same procedure of filling is followed as in the flume. The purpose of the column is to be able to study the bed structure at the start of the erosion experiments without destructing the bed. The layer thickness is measured visually, the density profiles are measured using the gamma-densimeter constructed in our lab.

The preparation of the bed is as follows: first the settling tank is mounted on the flume and filled with water, also the column is filled. For most experiments, except the preliminary ones, $3 \mathrm{~g} / \mathrm{l}$ salt is added. A sediment slurry is prepared by mixing the desired quantities of sand, cohesive sediment and (salt) water. After thorough mixing, the slurry is very slowly pumped into the tank, a proportional amount is poured into the column. To avoid large particles (shells, stones,..) in the bed, the slurry passes through a $2 \mathrm{~mm}$ sieve. Time, quantities and densities of the slurry are noted. This procedure is repeated twice a day. The amount of mass added at each time is a constant for all experiments. Also the supply rate is a constant. The filling is stopped when a bed thickness of $\pm 8 \mathrm{~cm}$ (after half a day of settling and consolidation) is reached; this can be checked in the settling column. The next day the density profile is measured and the settling tank is removed from the flume.

When the bed formation is finished by placement or deposition, the flume is slowly filled with water from the main system, the tailgate is in the highest position. After the consolidation period, the pumps are started and with the electrically operated valve the desired (small) discharge is 
installed. Slowly the tailgate is lowered to a predetermined level and the measuring can start. All these precautions are taken to prevent erosion due to the onset of the pumps.

A low discharge (no erosion) is kept for sufficiently long time to remove loose particles from the bed and the pipes. After a while a first 'background' concentration measurement is made.

Then step by step (intervals of about 30 minutes) the discharge is increased until the erosion starts. At this moment the discharge is kept constant for a longer period. Continuously (normally time interval of $20 \mathrm{~s}$ ) the computer measures water levels, upstream and downstream of the sediment bed, point velocities, discharge and the weight of the sediment trap. For the determination of the velocity profile the vertical position of the pitot tube is changed every 10 measurements. Suspended load samples are taken every 15 minutes. This procedure is repeated for a few (higher) discharges. The experiment is stopped when the erosion becomes too massive and the destruction of the bed causes the flow to be no longer uniform.

\subsection{Data processing}

\subsubsection{Flow conditions}

The measured parameters, used to characterise the hydraulic conditions of each experimental run, are the discharge, the upstream and downstream water level and the velocity profile. With these data, the average flow velocity, the slope of the energy line and the bed shear stress can be calculated. The different methods to calculate bed shear stresses are discussed in detail in 3.7.3. When processing the data after an experiment, the calibration formulas for each measuringinstrument are used to convert the data files, so that they give the measured parameters for each time step. Time averaging per file produces the mean water levels and discharge for each experimental run. To obtain the time average velocity profile, the point velocity measurements are averaged for each pitot tube position.

Knowing the width of the flume $(40 \mathrm{~cm})$, the average velocity can be calculated from the average discharge and water level. Due to side-wall and shape effects (see Chapter 5) this mean velocity can be different from the mean velocity of a measured centre line velocity profile. 
Through the two measured water levels, the water surface profile is calculated (using the computer programme CANAL, Pathirana et al. 1989) and as a result the slope of the energy line is obtained.

The accuracy of the different parameters is discussed in Appendix 2.

\subsubsection{Erosion and sediment transport}

With the measured bed load and suspended load data, erosion rates and sediment transport values can be calculated. Sediment transport is the amount of sediment by weight (or volume) being transported per unit of time, either as bed load or in suspension. In this definition no distinction of the origin of the sediments is made: they can come directly from erosion of the bed or they can be sediments pumped around in the system. The erosion rate is the amount of sediment eroded from the bed per unit of time and bed surface area. The erosion rate is thus the increase in sediment transport due to erosion from the sediment bed. Sediment transport and transport capacity (i.e., the maximum possible sediment transport at the given flow conditions) are mostly used for cohesionless sediments, whereas erosion rates are usually related to cohesive sediments. The bed load transport is calculated as the slope of the curve of the cumulated bed load (i.e., output load cell) versus time. Due to our definition of bed load, being all the sediments caught in the trap, this value divided by the sediment bed area is the erosion rate. No bed load is recirculating through the system.

The suspended load transport is defined as the average suspension concentration multiplied by the average discharge. By calculating the difference between the suspended load downstream of the sediment bed and the suspended load just upstream of the sediment bed the actual amount of sediment in suspension that eroded from the bed results. Multiplying this differential concentration with the average discharge and dividing it by the sediment area produces the erosion rate for the suspension transport.

The accuracy of the transport calculations is discussed in Appendix 2. 


\subsubsection{Bed shear stress}

Probably the most important parameter governing erosion and sediment transport is the bed shear stress: it represents the interaction between the flowing water and the sediment bed. The calculation of the bed shear stress can be done in two ways: from the measured velocity profile or from the slope of the energy line (using a side wall elimination technique). When dealing with a cohesionless sediment and bed forms, the bed shear stress needs to be converted into the grain shear stress, as explained in $\S 2.2 .2 . \mathrm{D}$.

\section{A. Velocity profile}

The theory developed by Prandtl and von Karman results in a logarithmic relation between depth and time averaged velocity at that depth:

$$
\frac{\mathrm{u}(\mathrm{z})}{\mathrm{u}_{*}}=\frac{1}{\mathrm{\kappa}} \ln \left(\frac{\mathrm{z}}{\mathrm{z}_{\mathrm{o}}}\right)
$$

with $u(z)$ the time averaged velocity at height $z$

u. the friction velocity, $\tau_{b}=\rho u^{2}$

$\rho$. density of water

$\tau_{b} \quad$ bed shear stress

$\kappa \quad$ von Karman coefficient

$z_{o} \quad$ reference level, where $u=0$

For the reference level the following expressions are proposed by Thijsse (1949):

$0.11 \mathrm{v} / \mathrm{u}$. for a smooth bed, $\operatorname{Re}_{*}<5$

$0.033 \mathrm{k}_{\mathrm{s}}$ for a rough bed, Re. $>70$

$0.11 \mathrm{v} / \mathrm{u}_{\mathrm{e}}+0.033 \mathrm{k}_{\mathrm{s}} \quad$ in the transition between rough and smooth.

The logarithmic Prandtl-von Karman velocity profile, also called the law of the wall (equation (3.1)), is assumed to be valid in the wall region, i.e., close to the bed (15\% of the water 
depth, Sarma 1993). Hence, when the measured velocity profiles are plotted on a semilogarithmical scale, a regression line can be calculated through the near bed data points. The friction velocity, and hence the bed shear stress, can be calculated from the slope of that line. In this way the bed shear stress in the middle of the cross section is calculated. When a uniform bed shear stress distribution is assumed, this value can be taken as the average bed shear stress. But due to the influence of the side walls and the narrowness of the flume a non uniform bed shear stress distribution is found. And the measured central bed shear stress is in fact the maximum value (see Chapter 5).

\section{B. Side wall elimination technique}

The bed shear stress can also be calculated from the flow conditions (equation 2.9). However, as mentioned above, the side walls have a significant effect on the shear stresses and hence, a special calculation technique needs to be applied to eliminate the influence of the walls. In this study the Vanoni-Brooks technique is used as explained e.g., in French (1985). Using this method, the total hydraulic radius is split up in two parts, one for the side walls and another one related to the sediment bed. It is the part related to the bed, that is used in the calculation of the bed shear stress, responsible for erosion and sediment transport:

$$
\tau_{b}=\rho g R_{b} S_{e}
$$

with $\mathrm{g} \quad$ acceleration of gravity

$R_{b} \quad$ hydraulic radius, corrected for wall effects (the side wall elimination technique is explained in Appendix 1)

$\mathrm{S}_{\mathrm{e}} \quad$ slope of the energy line, calculated from the water surface profile

Using equation (3.2) the average bed shear stress over the cross section is obtained. This value is then used in sediment transport calculations.

Later, it will be shown that for narrow flumes, the side wall elimination technique overestimates the average bed shear stress and represents in fact a maximum bed shear stress (see Chapter 5). 


\section{Sensitivity of the bed shear stress calculations}

As mentioned before, the bed shear stress is one of the most important parameters governing erosion processes. Hence, the accuracy of the different calculation methods needs to verified in detail. The main difficulty in the velocity profile method is the accurate determination of the reference level $z_{0}$. The determination of the zero velocity level $(u(z)=0)$ is a difficult task for a rough sediment bed (e.g., coarse sediments) or in the presence of bed forms. A previous study in the same rectangular flume (Kabir et al. 1992) showed that the velocity profile method is much more sensitive to small changes in the bed level than the side wall elimination technique is to small changes in the water level.

Table 3.2: Sensitivity analysis for the two different methods for the calculation of bed shear stress.

\begin{tabular}{c|c|c|c|c|c}
\hline \hline & \multicolumn{2}{|c|}{ Law of the wall calculations } & \multicolumn{2}{c}{ SWE-calculations } \\
\hline Level (cm) & $\mathrm{u}_{*}(\mathrm{~cm} / \mathrm{s})$ & $\mathrm{u}_{*} / \mathrm{u}_{*}(0)$ & $\mathrm{r}$ & $\mathrm{u}_{*}(\mathrm{~cm} / \mathrm{s})$ & $\mathrm{u}_{*} / \mathrm{u} .(0)$ \\
$(1)$ & $(2)$ & $(3)$ & $(4)$ & $(5)$ & $(6)$ \\
\hline 0.00 & 0.716 & 1.000 & 0.982 & 0.893 & 1.000 \\
0.05 & 0.806 & 1.126 & 0.987 & 0.896 & 1.003 \\
0.10 & 0.888 & 1.240 & 0.990 & 0.898 & 1.006 \\
0.15 & 0.965 & 1.348 & 0.992 & 0.902 & 1.010 \\
0.20 & 1.039 & 1.451 & 0.993 & 0.904 & 1.012 \\
0.50 & 1.505 & 2.102 & 0.995 & 1.256 & 1.406 \\
\hline \hline
\end{tabular}

In the present study a similar sensitivity analysis is carried out. The results are given in Table 3.2. The velocity profiles were measured using the pitot tube in case of a smooth bed, i.e., without bed forms. The zero level position of the pitot tube was determined visually. The first column indicates a small change in reference level, i.e., an error on the position of the pitot tube for the velocity distribution or a change in water level for the side wall elimination calculation. A small 
variation of $0.5 \mathrm{~mm}$ causes an error of $12.6 \%$ in the friction velocity from the velocity profile (column 3, Table 3.2), but only $0.3 \%$ change in the friction velocity from the side wall elimination (column 6, Table 3.2).

Sometimes the "exact" reference level for the velocity profile is taken as the level for which the regression coefficient for the calculated logarithmical profile through the measured velocities is maximum (van Rijn 1989). All the regression coefficients for the above sensitivity analysis (column 4, Table 3.2) are close to 1, indicating a reliable curve fit. For the level $0.5 \mathrm{~cm}$ a maximum value is found, which is only $1 \%$ more than the regression coefficient at level $0.0 \mathrm{~cm}$, so the improvement is not significant. Moreover, a level of $0.5 \mathrm{~cm}$ means an error on the visual positioning of the pitot tube above the smooth bed, that is larger than the dimensions of the instrument (external diameter $0.3 \mathrm{~cm}$ ). Such an error is unrealistic.

The sensitivity analysis proves that the computation of $\tau_{b}$ from the velocity profile is much more sensitive to measurement errors than the side wall elimination calculations. For rough beds or bed forms these measurement errors are practically inevitable (Kabir et al. 1992). For smooth beds the determination of the bed level (i.e., zero level position for the pitot tube) can be done quite accurately. However, even an error of $0.05 \mathrm{~cm}$ causes errors of $10 \%$ in the calculated shear velocity. Avoiding these errors by calculating the reference level as the level for which the regression coefficient is maximum, is not a valuable solution. Therefore, in the present study the bed shear stresses are calculated using the side wall elimination technique. Only when the shear stress distribution over the cross section needs to be known (Chapter 5), the shear stresses are calculated from the measured velocity profiles. In that case special attention is paid to the local velocity registrations with the pitot tube and only smooth bed conditions are taken into account in the data analysis. More details on the sensitivity and accuracy of these calculations can be found in Appendix 2.

Comparison between the experimental results of Leuven (rectangular cross section ) and Gent (semi-circular cross section) showed the importance of shape and scale effects on bed shear stress distributions. These aspects are studied in Chapter 5. 


\subsection{Summary}

To study the erosion of mud/sand mixtures in uniform flow, it was decided to start a set of laboratory experiments in a straight flume with a rectangular cross section. The main reason for laboratory work is to study different aspects of mixture behaviour separately. Due to national and international collaboration, the laboratory data could be compared with other data both from lab and field studies.

Two types of experiments are performed. The first type is the erosion of homogeneous sediment mixtures, prepared outside the flume and then placed in the measuring section. The second type of experiments deals with deposited, layered beds. For these tests a settling tank has been constructed, so that the mixed sediment suspension can settle into the measuring section of the flume. A settling column was used to closely follow the built up of the bed. For both types of experiments, mixtures are made of one type of sand and several types of cohesive material, artificial as well as natural muds. During the erosion tests continuously the flow parameters and sediment transport are measured; after the test the properties of the sediment mixtures are analysed. During the data processing special attention is paid to the calculation of bed shear stresses.

In this chapter the experimental flume, the measuring-instruments, the experimental procedure and the data processing techniques have been described in detail. The hydraulic conditions and measured erosion rates for every experimental run are brought together per type of experiment and per type of cohesive sediment in tables in Appendix 3. The accuracy of these data is discussed in Appendix 2. 


\section{Chapter 4: Experimental results}

\subsection{Introduction}

This chapter gives an overview of the results of all the erosion experiments on mud/sand mixtures carried out in the straight rectangular flume. Especially the erosion resistance and the measured erosion and transport rates will be discussed. The experimental procedure is described in the previous chapter (Chapter 3). In this overview a distinction is made between the two types of erosion experiments: homogeneous placed mud/sand mixtures ( $\$ 4.3)$ and layered deposited mixtures ( $\$ 4.4)$. First ( $\$ 4.2$ ) some preliminary experiments on the erosion of sand beds have been carried out. In a last paragraph $(\$ 4.5)$ all the results on the erosional behaviour of mud/sand mixtures in uniform flow are summarized and the influence of different parameters - mixture composition, type of cohesive sediment, density, bed structure - is discussed.

\subsection{Preliminary experiments on the erosion of sand}

\subsubsection{Aim of the preliminary experiments}

The aim of the erosion experiments on sand beds is double. First of all, the performance of the experimental flume and the measuring-instruments are thoroughly checked during these tests. The behaviour of a uniform sand bed in uniform flow conditions is well-known and many theories exist to predict this behaviour ( $\$ 2.2$ ). The comparison of our data and observations with these theories gives a good indication of the performance of the experimental installation.

The second aim of the preliminary experiments is that these experiments will serve as a reference for the experiments on mixtures, especially for the homogeneous placed mixtures. Comparing the mixture data with the data for pure sand, will provide an idea about the influence of adding a cohesive fraction to sand. 
Three sets of erosion experiments using sand from Mol, the same sand as is used in the preparation of the mixtures, have been carried out. The mean diameter $\left(\mathrm{d}_{50}\right)$ of this uniform, fine sand is $0.23 \mathrm{~mm}$ (see Figure 3.7). The experimental procedure is exactly the same as described in $\S 3.6$ for the mixture tests. The discharge is stepwise increased but when incipient motion conditions are reached, only a few higher flow rates are applied to avoid irregular flow conditions. The experimental conditions and the results are brought together in a table in Appendix 3.

As soon as sediment transport starts, as expected, bed forms appear: ripples or dunes. The bed forms are quite uniform along the width and length of the sediment section, indicating no abnormalities in the flow over the sediment bed. Only at the transition from rigid to movable bed locally deep scour holes can occur. The sand is mainly transported as bed load, although, for higher discharges, some suspended load has been observed as well. No accurate measurements of the suspension concentrations exist. Some samples $(0.5 \mathrm{l})$ were taken and weighed in order to determine the concentration of suspended solids (order of magnitude $10 \mathrm{mg} / \mathrm{l}$ ) from the density of the sample, but because of the low accuracy of the used balance $(0.1 \mathrm{~g})$ this method did not produce usable results. All the other measuring-techniques proved to be performing allright and gave accurate enough data. The accuracy of the experimental data is discussed in Appendix 2. The formation of scour holes can be prevented by the use of a sediment feeder. But since we were not planning on using a sediment feeder in the mixture experiments, also in the reference sand tests no feeder is used. To account for the bed form roughness, the grain resistance is calculated, when processing the data. The grain shear stress $\tau_{b}{ }^{\prime}$ (or $\theta_{b}{ }^{\prime}$ calculated according to EngelundHansen $\S 2.2 .2, D$ ) is the parameter governing the sediment transport.

\section{A. Critical shear stress for erosion}

To determine the experimental value of the critical bed shear stress for erosion of the sand, the measured transport parameter $\Phi$ (dimensionless sediment transport as defined by Einstein, $\S 2.2 .2$, equation (2.16)) is plotted versus the dimensionless grain shear stress $\theta_{b}^{\prime}$ (Figure 4.1). 
By extrapolating these data towards $\Phi=$ zero, the critical value of $\theta_{b}{ }^{\prime}$ is obtained as $0.09 \pm 0.01$, corresponding to $\tau_{\mathrm{cr}}=0.35 \pm 0.04 \mathrm{~Pa}$. This value will be the reference to evaluate the influence of cohesion on erosion resistance.

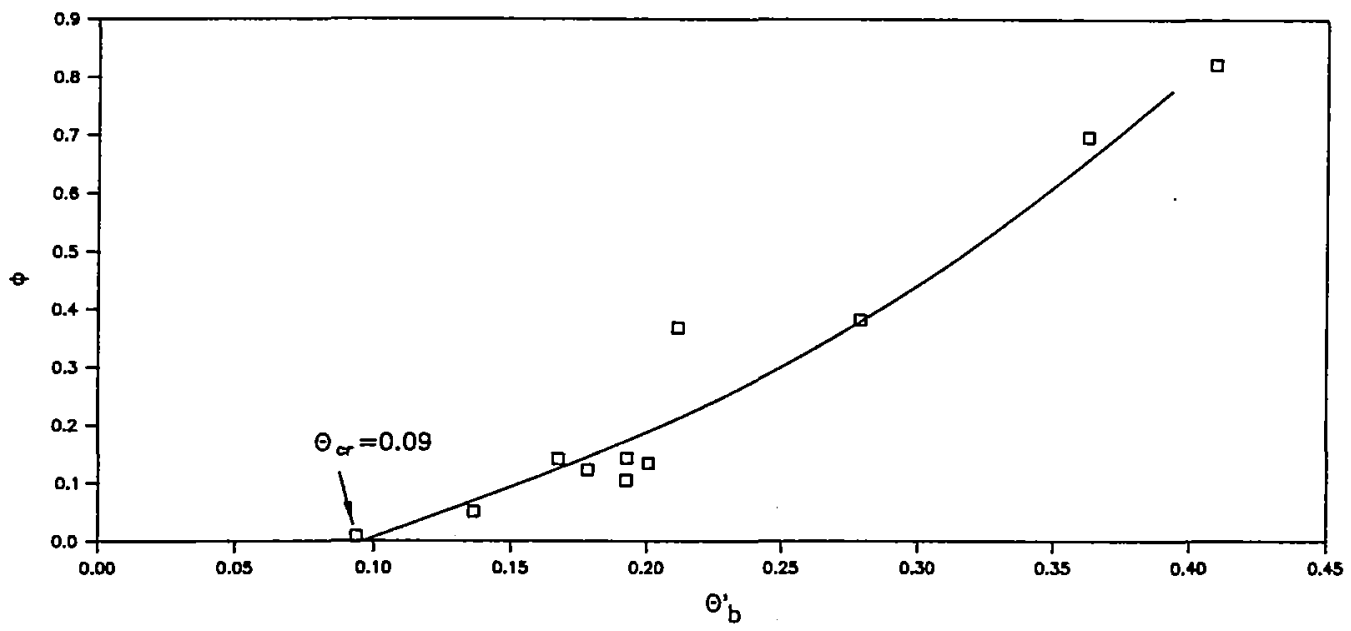

Figure 4.1: Experimental determination of the critical mobility number for sand.

Using the Shields diagram (Figure 2.2, § 2.2.1), a critical value for the Shields parameter $\theta_{\mathrm{cr}}= \pm 0.05$ is derived. Hence, the "theoretical" value for $\tau_{\mathrm{cr}}$ lies around $0.20 \mathrm{~Pa}$ This means that the experimental value is almost twice the Shields value. Due to the stochastic nature of sediment transport, as explained in $\S 2.2 .1$, and because of the different definitions for critical shear stress, differences like that are to be expected.

Remark: At incipient motion conditions no bed forms exist, hence the bed shear stress is by definition equal to the grain shear stress $\left(\theta_{b}=\theta_{b}{ }^{\prime}\right)$.

\section{B. Sediment transport rates}

According to the principles of sediment transport, there must be a relation between the measured sediment transport and the applied grain shear stress. For cohesive sediments, it is very common 


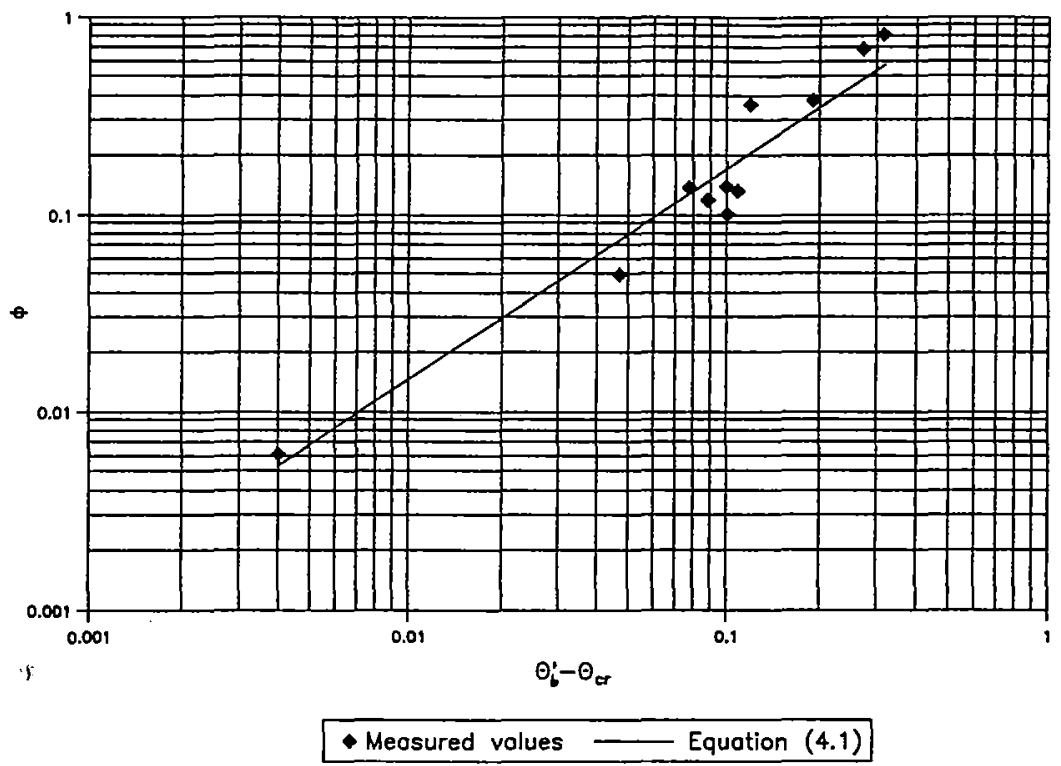

Figure 4.2: Comparison between measured values and bed load predicted using equation (4.1).

to express the erosion rate as a function of excess shear stress (see $\S 2.3$ ). Since one of the aims of these preliminary experiments is to serve as a reference for the mixture tests, we choose to plot the measured sediment transport data against the excess shear stress (Figure 4.2). Both sediment transport $(\Phi)$ and excess shear stress $\left(\theta_{b}{ }^{\prime}-\theta_{c r}\right)$ are made dimensionless and for $\theta_{c r}{ }^{\prime}$ the experimentally determined value is used. It can be shown that the erosion rate is proportional to $\Phi$ and the dimensionless shear stress is of course proportional to the shear stress. In this way later comparisons are facilitated.

By regression analysis $(r=0.97)$, the following relation is found between the experimental data (Figure 4.2):

$$
\Phi=1.97\left(\theta_{b}{ }^{\prime}-\theta_{c r}{ }^{1.07}\right.
$$

This means that for the range of shear stresses used in these experiments, the bed load transport increases almost linearly with the excess shear stress. 


\section{Comparison with existing transport formulas}

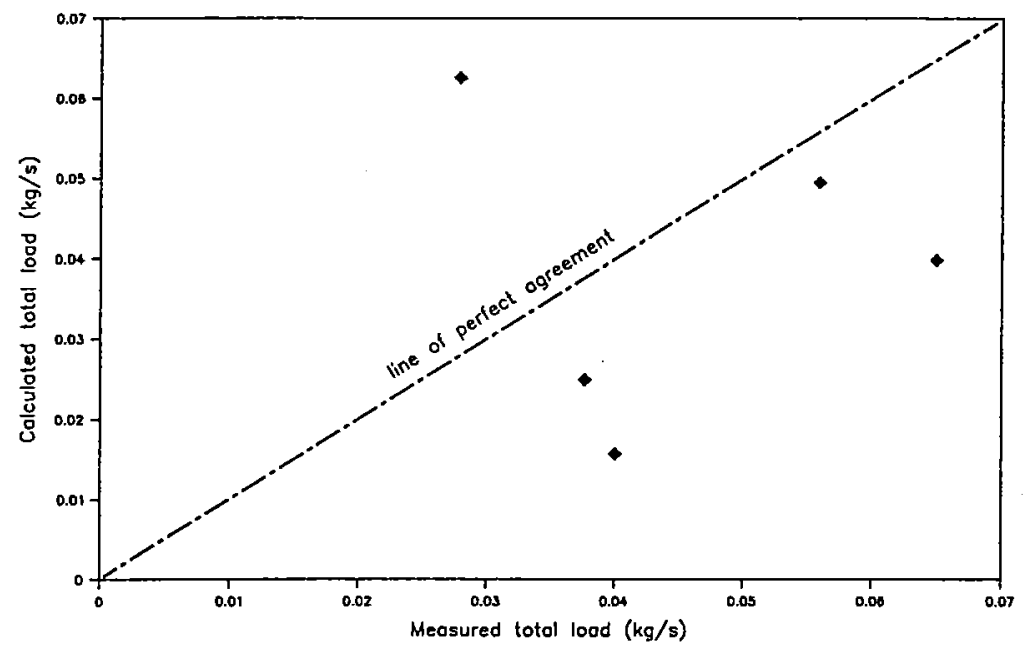

Figure 4.3: Comparison with the Ackers and White total load formula.

The measured transport values have been compared with some existing transport formulas. In Figure 4.3 the measured total load (i.e., the sum of bed load and suspended load) is compared with the values predicted by the total load formula of Ackers and White $(\$ 2.2 .2, \mathrm{~A})$. Suspended load data only exist for five experiments. The limited data are very scattered and most measured values are about twice as high as the calculated values. This may be partially due to the inaccurate measurements of the suspended load.

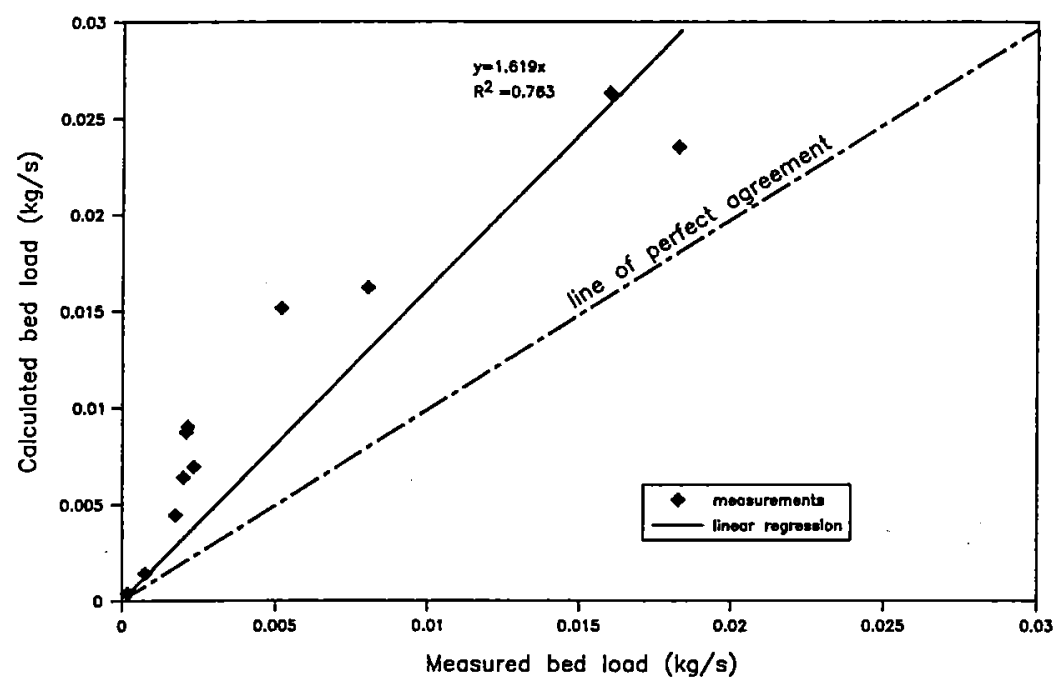

Figure 4.4: Comparison with the van Rijn bed load equation. 
The bed load formula of van Rijn $(\$ 2.2 .2, \mathrm{~B})$ was developed for uniform sediment ranging from 0.2 to $2 \mathrm{~mm}$; the sand used in these experiments falls in this range.

Figure 4.4 shows that the van Rijn bed load formula overpredicts the measured bed load by a factor 1.62. However, there seems to be a good correlation between measured and calculated values $(r=0.87)$. The overprediction may be caused by shape or scale effects related to our flume.

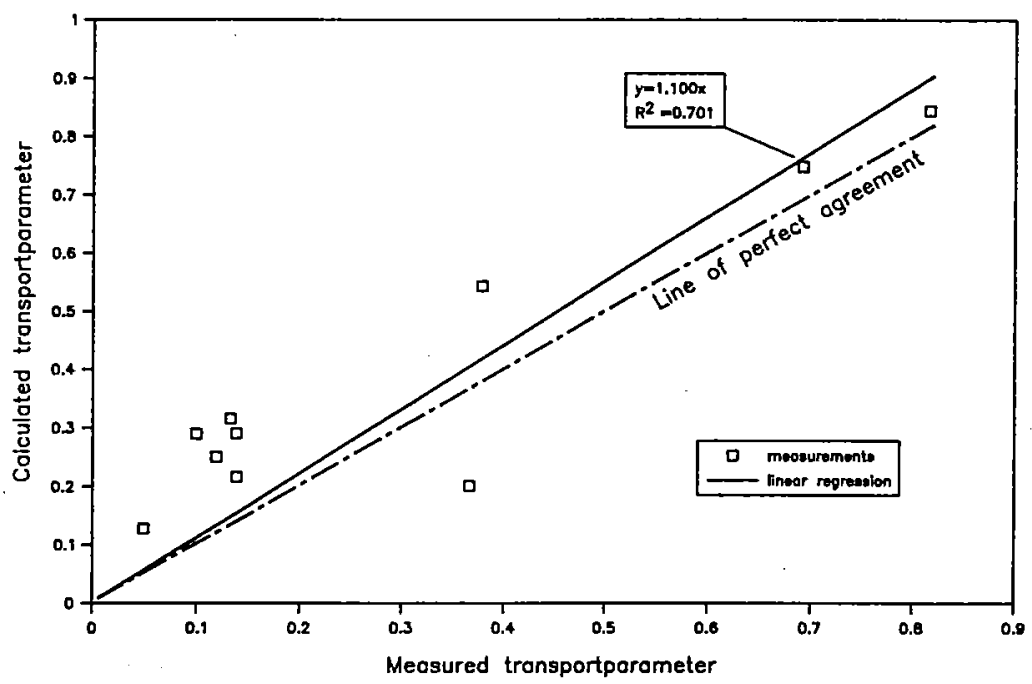

Figure 4.5: Comparison with Einstein's bed load function.

The next plot, Figure 4.5, presents the comparison between the measured bed load and the values predicted using Einstein's bed load equation $(\$ 2.2 .2, \mathrm{C})$. The data fall very close to the line of perfect agreement, although there is a tendency to overpredict the measurements just a little bit, by a factor $1.10(r=0.88)$. In fact, Einstein's bed load equation seems to perform best in predicting the sand transport in our flume.

It is generally accepted (e.g., van Rijn 1989) that a sediment transport formula performs well if the discrepancy ratio, defined as the ratio between the predicted and the measured value, lies in between 0.5 and 2.0 .

From our comparison it can be concluded that the agreement between measured and predicted bed load in this study is very satisfactory: all formulas yield discrepancy ratios between 0.5 and 2. The order of magnitude of predicted and measured values does not differ. The flume does not 
produce irrational values for sediment transport. Only the measurement of suspended load has been a problem in the preliminary experiments, but this has been solved prior to further tests: more accurate measurements of suspended solids concentrations can be obtained by filtration of the samples as explained in $\S 3.3 .5$.

\subsection{Erosion of homogeneous mixtures}

\subsubsection{Aim of the experiments}

The first type of erosion experiments are the tests with homogeneous, placed sediment mixtures. As explained in the previous chapter $(\$ 3.5)$ the properties of the sediment bed: density and mixture composition, are assumed to be homogeneous over the total depth of the sediment layer. The preparation of these type of mixtures is explained in $\S 3.6$.

The main purpose of these experiments is to look at the transition from cohesionless to cohesive erosional behaviour by stepwise increasing the amount of cohesive material in the mixture. Therefore, the impact of the amount of cohesive material on the erosion resistance and erosion rates is measured. Secondly the influence of the type of cohesive sediment and the effect of bed density and consolidation time will be studied.

First an extensive set of experiments is done with mixtures of sand and artificial cohesive sediments: kaolinite and montmorillonite. By using clay as cohesive fraction in the mixtures, the complicated effects of e.g., the organic content and biological processes in natural muds are avoided. Afterwards, some of the experiments are repeated with Scheldt mud mixtures to see whether the behaviour of the artificial sediments is representative for natural mud. Two types of mud are used in these experiments. Table 3.1 gives an overview of the mixture compositions. All experimental results are brought together in a table in Appendix 3. 
During the experiments with different mixtures, different modes of erosion are observed, depending on the type and amount of cohesive sediments in the mixture, the bed density and the consolidation time. The differences can be seen in the bed forms or erosion patterns, in the size and nature of the eroded particles and in the way the eroded particles are transported either in suspension or as bed load.

Some mixtures of sand and cohesive sediment (montmorillonite, kaolinite and mud), but with a very low content of fines (i.e., only a few percent smaller than $63 \mu \mathrm{m}$ ), behave as non cohesive sediments. The small amount of cohesive sediment in the mixture does not seem to affect the erosion process. When erosion starts, the fine clay particles are washed out from the top layer, leaving only the sand. This process can be observed through the glass walls: the suspension becomes a little less transparent, due to the clay being washed out, and the colour of the remaining bed indicates that only the sand fraction has been left behind. Teeter (1994) made similar observations during his experiments on mixtures of kaolinite and silts: at low bed shear stresses only the fine kaolinite was washed out of the sediment surface. With increasing discharge, ripples and dunes, consisting of sand only, appear on the bed. The sand is mainly transported as bed load. However, with increasing amount of fines in the mixture, this formation of ripples and dunes is more and more suppressed, as was already found by Collins (1989), until the mixture is no longer cohesionless.

When the mixtures contain a higher fraction of cohesive sediment, the mode of erosion changes into cohesive sediment erosion: surface erosion or mass erosion ( $\$ 2.3 .2)$. Visual observations of the experiments learn that the erosion of some kaolinite mixtures and some mud mixtures is very slow and that the bed appears to be wavy after the erosion. The colour of the sediment bed indicates that the undulations are no sand ripples or dunes, but they appear to consist of the original sediment mixture, indicating that possibly surface erosion took place. Looking at the way the eroded sediments are transported, only for the low density kaolinite mixtures the eroded aggregates are immediately suspended. For denser mixtures, bed load transport becomes much more important than suspended load. 
For most of the erosion experiments on dense homogeneous mixtures, the erosion can be described as mass erosion. Erosion starts very sudden but once the erosion has started at some spots, further removal of bed material proceeds quite rapidly. Erosion in depth of an existing eroded spot seems to be easier than the start of erosion on a new place of the intact sediment surface. This phenomenon can have two explanations. Once erosion has started, local turbulence, and hence the bed shear stress, increases on that spot due to the irregular bed topography, facilitating further erosion. The rest of the surface is still very smooth and therefore harder to erode. Another complementary explanation is the formation of a resistant top layer after the placement of the bed. Especially for the mud mixtures, a change in colour of the top layer (order of magnitude a few millimetres thick) is noticeable: oxidation cannot be the reason for this colour change, because the mixture is always kept under water. Once this layer is removed, the erosion becomes easier. Probably this top layer has a stronger structure, comparable to the armour layer in cohesionless sediment transport. Partheniades (1965) reported that after his laboratory erosion tests there was a thin but strong crust on uneroded parts of the sediment bed.

The eroded material consists of large pieces of mixture (order of magnitude up to $1 \mathrm{~cm}$ ) and is mainly transported as bed load. Whole crumbs, plates of bed material move close to the bed towards the sediment trap. The eroded entities do not disintegrate. They behave as large cohesionless particles. Amos et al. (1994a\&b) describe field erosion test using their Sea Carousel, during which the erosion process was filmed. The erosion of dense sediment mixtures $\left(1500-2000 \mathrm{~kg} / \mathrm{m}^{3}\right.$ ) partially took place as a rapid removal of large, irregular clasts of soil (up to $7 \mathrm{~mm}$ in diameter). The erosion occurred through excavation of small irregularities in the bed. Einsele et al. (1974) describe a similar erosion process as "discontinuous erosion".

No distinct bedforms occur but mostly, especially for the montmorillonite mixtures, one or more grooves are formed along the sediment bed, as also reported by Partheniades (1965), even during some of the experiments on low density montmorillonite mixtures. The formation of an erosion groove can be explained by looking at the bed shear stress distribution (see Chapter 5 ). Due to the influence of the side walls, the bed shear stress is higher along the centre line than close to the walls. Erosion will therefore preferentially take place in the central section. In other cases local erosion holes are formed. And sometimes, together with the formation of a groove and the occurrence of mass erosion, sand ripples move over the bed as well. Analysis of the composition of different parts of the bed after an erosion experiment, shows that the groove material has the 
same composition as the original mixture, but other parts of the surface, where only slight erosion took place, contain more fines. Probably the sand in the ripples comes from there.

For some experiments on montmorillonite mixtures the mode of erosion is not comparable to either cohesionless or cohesive erosion. No specific bed forms develop and the erosion seems to start around irregularities in the bed. These irregularities can be due to insufficient mixing or due to small deficiencies in the surface of the sediment bed. At low discharges some of the fines are still washed out. Intermediate flow rates cause sometimes the formation of grooves but at higher discharges an irregular but overall erosion occurs. The erosional behaviour in these experiments, on mixtures with an intermediate content of fines, forms some sort of transition from cohesionless to cohesive behaviour. For the kaolinite and mud mixtures this transition type of erosion was not encountered in the experiments. The transition from cohesionless to cohesive occurs rather abrupt. For both types of cohesive sediments, only during the experiments on a mixture containing around $3 \%$ fines ripple and dune formation is observed. At higher amounts of fines, the mixture becomes cohesive.

\subsubsection{Measured erosion resistance}

The erosion resistance of the different mixtures can be defined in many ways. The critical shear stress for erosion is the most used measure for erosion resistance. But even for the critical shear stress different definitions exist (Chapter 2). The erosion rates at a certain bed shear stress can also be compared in order to evaluate the erosion resistance of a certain mixture.

To determine the critical bed shear stress for a certain sediment bed, the following procedure was used. During each experiment the discharge was increased in small steps. At one discharge, $Q_{j}$, there is no erosion: the load cell indicates continuously the same weight for the sediment trap and the suspension samples contain only "clear" water. In fact the water is never perfectly clear, there is always a background concentration: sediment accumulates in different parts of the system (pipes, reservoirs). At the next step, $Q_{i+1}$, there is erosion: sediment is falling into the sediment trap and/or the samples contain some (more) suspended sediment. Both stages can also be 
observed in the flume: when the erosion just starts the water is still clear enough to follow the erosional processes near the sediment bed. In fact the moment of incipient motion is somewhere in between stage $i$ and $i+1$. Hence, the critical shear stress is calculated as the average of the bed shear stresses $\tau_{i}$ and $\tau_{i+1}$. The accuracy of the calculated critical shear stress depends on the magnitude of the discharge step, as discussed in Appendix 2.

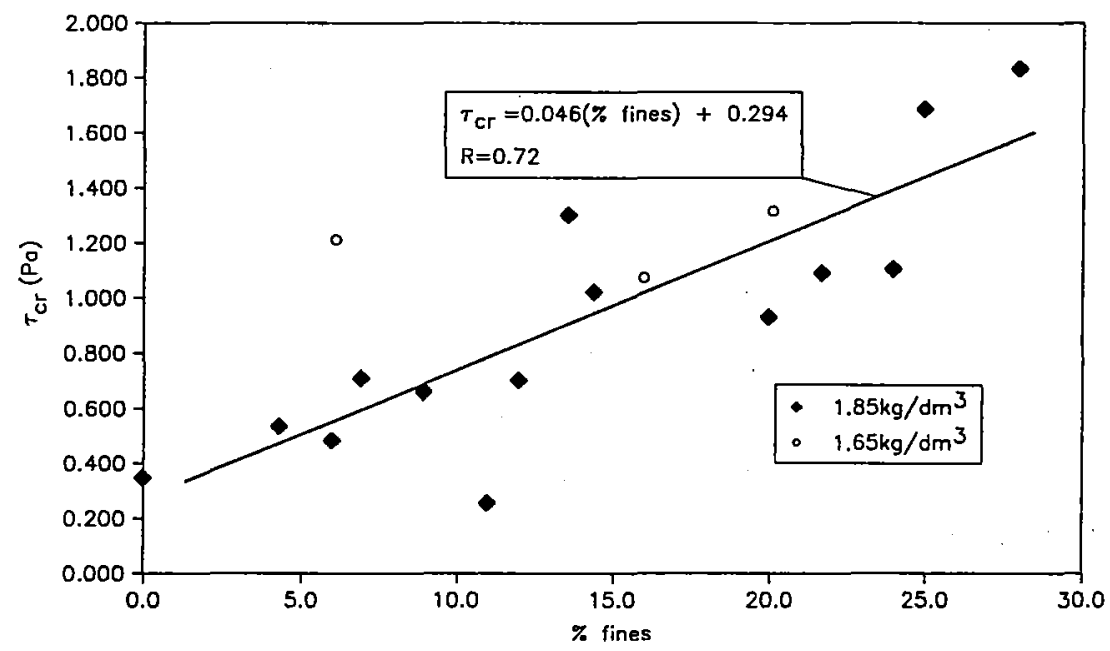

Figure 4.6: Measured critical shear stresses for the montmorillonite mixtures.

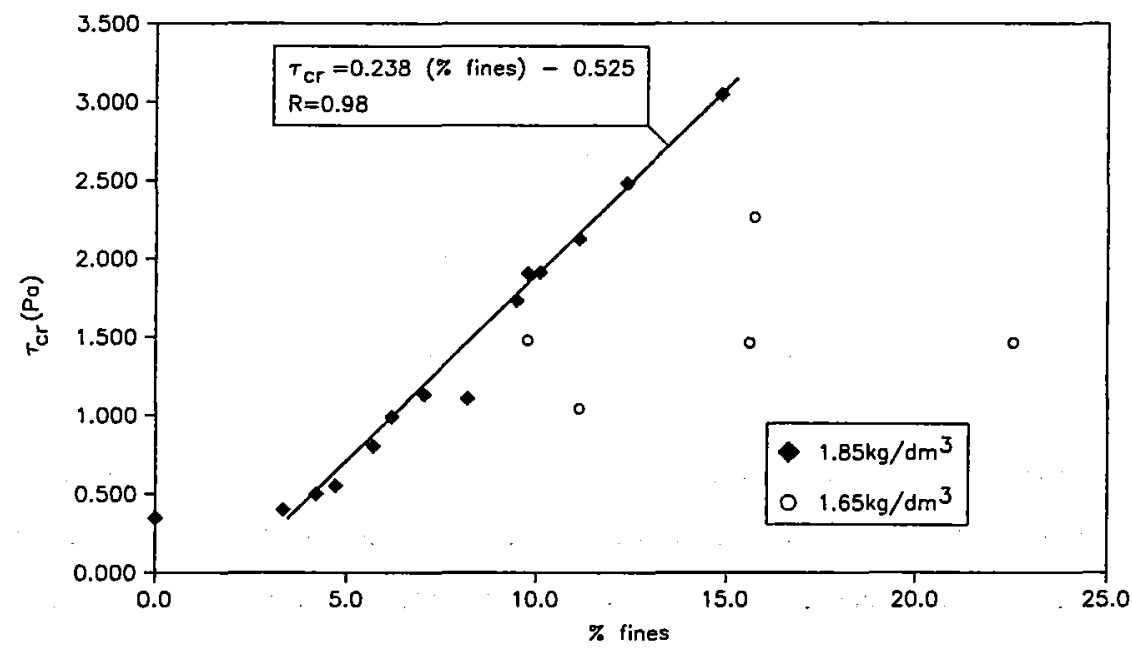

Figure 4.7: Measured critical shear stresses for kaolinite mixtures. 


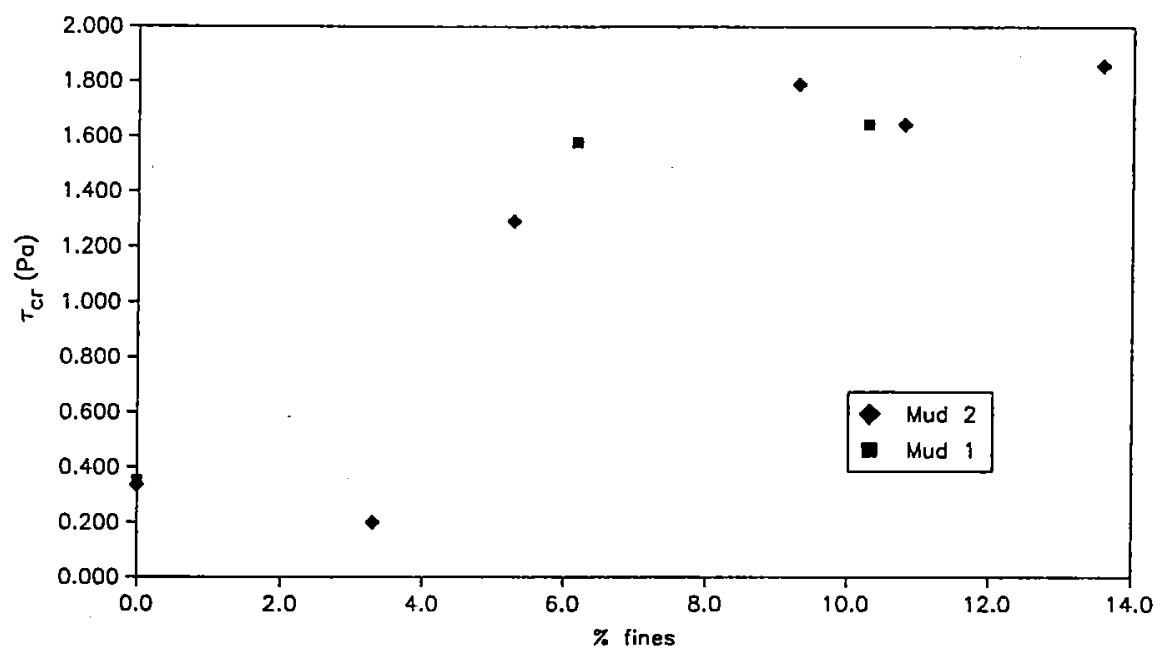

Figure 4.8: Measured critical shear stresses for mud mixtures.

In Figures 4.6, 4.7, 4.8 the critical shear stress is plotted as a function of \%fines (i.e., percentage by weight of material smaller than $63 \mu \mathrm{m}$ ) for the different homogeneous mixtures. For every type of mixture a more or less linear increase in critical shear stress with mixture composition is found until the maximum amount of fines. This maximum content of fines is determined by the maximum bed shear stress that can be produced in the flume. E.g., a montmorillonite mixture of $42 \%$ fines could not be eroded, even when the sediment surface was deliberately scarfed. For the kaolinite mixtures $15 \%$ is the maximum erodible clay content for the dense mixtures.

For the kaolinite mixtures an almost perfect linear relation is found between critical shear stress and clay content (Figure 4.7). When the amount of fines varies between 3 and $15 \%$, the erosion resistance changes according to:

$$
\tau_{\mathrm{cr}}=0.24(\% \text { fines })-0.53
$$

A similar relation (equation (4.3)) can be derived for the montmorillonite mixtures containing between 4 and $25 \%$ fines, although the linearity is less obvious (Figure 4.6), especially in the transition zone: between 7 and $13 \%$ fines the critical shear stress varies significantly.

$$
\tau_{\mathrm{cr}}=0.046 \text { (\%fines) }+0.29
$$


The measured critical shear stress of a mixture seems always higher than the critical shear stress for sand only. Even the addition of a small amount of cohesive sediment enhances the erosion resistance of the mixture, although the mode of erosion does not change significantly. Adding fines to the sand makes the sediment bed much smoother and hence, harder to erode. On the other hand, the erosion of mixtures with a very small clay content starts with the washing out of the fines. This causes a very small, probably not measurable, increase in suspended load. Therefore, it could be that the real critical shear stress for erosion for these mixtures is in fact a little lower than the measured value and even lower than the measured critical shear stress for sand. For the mud2 mixtures (Figure 4.8) a critical shear stress of $0.2 \mathrm{~Pa}$ is calculated for the $3.3 \%$ fines mixture, which is of course lower than the sand erosion resistance of $0.35 \mathrm{~Pa}$. For the kaolinite mixture containing around $3 \%$ fines, the measured critical shear stress $(0.4 \mathrm{~Pa})$ is in fact almost the same as the critical shear stress for sand only $(0.35 \mathrm{~Pa})$. These two examples suggest that indeed a decrease of erosion resistance can be expected when a very small amount of fine sediment is added to sand. This small amount of cohesive sediment does not create any bonding between the particles or smoothening of the sediment surface.

The further increase in erosion resistance with increasing \%fines can be attributed to the formation of cohesive bonds between the different particles in the mixture. These bonds create an extra erosion resistance. In fact, from a certain amount of cohesive sediment in a mixture, the effect of cohesion will be much more important than the smoothening of the surface (see Chapter 6).

A sediment bed of pure montmorillonite clay at the same density as the mixtures $\left(1.8 \mathrm{~kg} / \mathrm{dm}^{3}\right)$ has an erosion resistance exceeding the flume capacities. Hence, the critical shear stress of $100 \%$ clay is higher than the measured critical shear stress for sand. Whether in between the erosion resistance will keep increasing or will pass through a maximum value is not clear. Other researchers (Amos et al. 1994, Williamson et al. 1992) found that the erosion resistance increased when the sand content of the sediment increased (between 0 and about $60 \%$ sand). However, it is not clear from their data whether the increasing sand content is the only reason for this increasing erosion resistance, since the bed density is increasing with sand content as well. Erosion experiments starting form pure clay and adding gradually more sand but at a constant bed 
bed density are needed to clarify this phenomenon. However, this topic falls outside the scope of this study. Alvarez (1990) found an optimum mixture composition, around 20 to $40 \%$ fines, with maximum erosion resistance for his experiments on mixtures of sand and Laponite clay.

Comparison between the different types of cohesive sediment (Figures 4.6,4.7,4.8) learns that for the same amount of fines and for the same bed density, the kaolinite mixtures have a much higher erosion resistance: $0.5-3 \mathrm{~Pa}$. The increase of erosion resistance with \%fines of the kaolinite mixtures is 5 times the increase for the montmorillonite mixtures (equations $(4.2,4.3)$ ). Kaolinite is also the finest sediment (see grain size distribution, Figure 3.7) of all the cohesive sediments used, more than $75 \%$ of the kaolinite is smaller than $2 \mu \mathrm{m}$. These fine particles fill all the pores between the sand grains and reduce the erodibility significantly. The two types of Scheldt mud mixtures have more or less the same critical shear stress for erosion between 1 and $2 \mathrm{~Pa}$. The montmorillonite mixtures posses the lowest erosion resistance, between 0.4 and $1.4 \mathrm{~Pa}$.

In Appendix 3 an overview is given of the measured critical shear stresses for all experiments on homogeneous mixtures.

Table 4.1: Examples of critical shear stresses $\left(\tau_{\mathrm{cr}}\right)$ for the erosion of dense cohesive sediments and mixtures ( $\rho_{b}$ is the bulk density of the sediments).

\begin{tabular}{|c|c|c|c|}
\hline Researcher & $\begin{array}{l}\rho_{\mathrm{b}} \\
\left(\mathrm{kg} / \mathrm{dm}^{3}\right)\end{array}$ & $\tau_{\mathrm{cr}}(\mathrm{Pa})$ & Remarks \\
\hline Einsele et al. (1974) & - & 1.3 & Kaolinite, flume \\
\hline \multirow[t]{2}{*}{ Amos et al: (1985) } & 1.6 & 3.6 & Windsor mud, field survey \\
\hline & 1.82 & 8.0 & Evangeline mud, field survey \\
\hline Alvarez (1990) & - & $1-6$ & Laponite/sand mixture, flume \\
\hline Mehta (1991) & $>1.2$ & $>2$ & Mass erosion shear strength \\
\hline Amos et al. (1994) & $1.65-2.0$ & $0.7-10$ & Manitounuk Sound, Sea Carousel \\
\hline Wotherspoon (1994) & $1.7-1.85$ & $1.5-2$ & Sewer sediments, in situ \\
\hline
\end{tabular}

In Table 4.1 some values of critical shear stresses from literature are brought together. The values are both from laboratory and field investigations on the erosion of cohesive sediments and 
mixtures, having similar bulk densities as the mixtures tested. If these values are compared to our experimental data, in Figures 4.6, 4.7, 4.8, it becomes clear that the erosion resistance of the studied cohesive mixtures is quite similar to that of the cohesive sediments described in previous studies, in the laboratory as well as in the field.

When the bulk density of a mixture decreases, its erosion resistance decreases as well. The distance between the particles increases and the bonds between them become less strong. In Figure 4.7 the critical shear stresses for erosion of kaolinite mixtures of two different bed densities are compared as a function of mixture composition. The low density mixtures have a significantly smaller erosion resistance. However, the data are very scattered. This is due to small differences in the bed density of these mixtures. The exact mixture composition and hence, density, is difficult to control in advance. Small changes in bed density seem to have a much greater influence on the erosional behaviour when the density of the sediment bed decreases. For the montmorillonite mixtures the influence of the bed density on the critical shear stress for erosion is less apparent (Figure 4.6). Again the low density data vary a lot due to variations in the mixture density. Visual observation of those experiments learns that the erosion of the low density montmorillonite mixtures is similar to the mass erosion of the high density mixtures. This could be the reason for the similar erosion resistance. For kaolinite mixtures the mode of erosion changes from mass erosion at high density to surface erosion at low density, leading to different mechanisms for erosion resistance as well.

The consolidation time of the sediment bed has a similar impact on the erosion resistance. Normally a consolidation time of one night is applied for the high density mixtures (i.e., $\left.1850 \mathrm{~kg} / \mathrm{m}^{3}\right)$. But the influence of the consolidation time has been checked in some specific experiments. For instance a montmorillonite mixture, containing $22 \%$ fines, is eroded immediately after the preparation of the bed. A critical shear stress of $0.7 \mathrm{~Pa}$ is found. When a similar mixture consolidates for one night, the measured critical shear stress is $1.1 \mathrm{~Pa}$. During the consolidation period, the remoulded sediment has the opportunity to regain strength and structure, although the increase in density (or decrease in water content) was found to be less important. 
Another way to evaluate the erosion resistance of different mixtures is shown in Figures 4.9, $4.10,4.11$. The erosion rates of different mixtures are compared as a function of applied bed shear stresses, for kaolinite, montmorillonite and mudl mixtures.

Again these figures clearly demonstrate that the erosion resistance increases with increasing content of fines. In each graph the measured erosion rates decrease with increasing \%fines in the mixture, for the same bed shear stress. For the montmorillonite mixtures (Figure 4.9) the change in erosion rates is very gradual. The $4.3 \%$ mixture behaves almost the same as sand and similarly no significant difference exist between 7 and $9 \%$ mixtures. But for the kaolinite and mud mixtures (Figures $4.10,4.11$ ) the increase of amount of cohesive material in the mixture has a much stronger effect. To establish an erosion rate of $0.001 \mathrm{~kg} / \mathrm{sm}^{2}$, a bed shear stress around $0.5 \mathrm{~Pa}$ is needed for the $3 \%$ kaolinite mixture. Whereas about three times that shear stress $(1.6 \mathrm{~Pa})$ is needed to have the same erosion of the $4.2 \%$ mixture. When the erosion of the montmorillonite mixture containing $4.3 \%$ fines is compared with the kaolinite mixture with a similar mixture composition ( $4.2 \%$ fines) the erosion rates at the same bed shear stress are about an order of magnitude higher for the montmorillonite mixtures. At a bed shear stress of $1.5 \mathrm{~Pa}$ the measured erosion rates are $0.011 \mathrm{~kg} / \mathrm{sm}^{2}$ for the montmorillonite mixture and $0.001 \mathrm{~kg} / \mathrm{sm}^{2}$ for the kaolinite mixture. This again proves the much higher erosion resistance of the kaolinite mixtures compared to the montmorillonite mixtures.

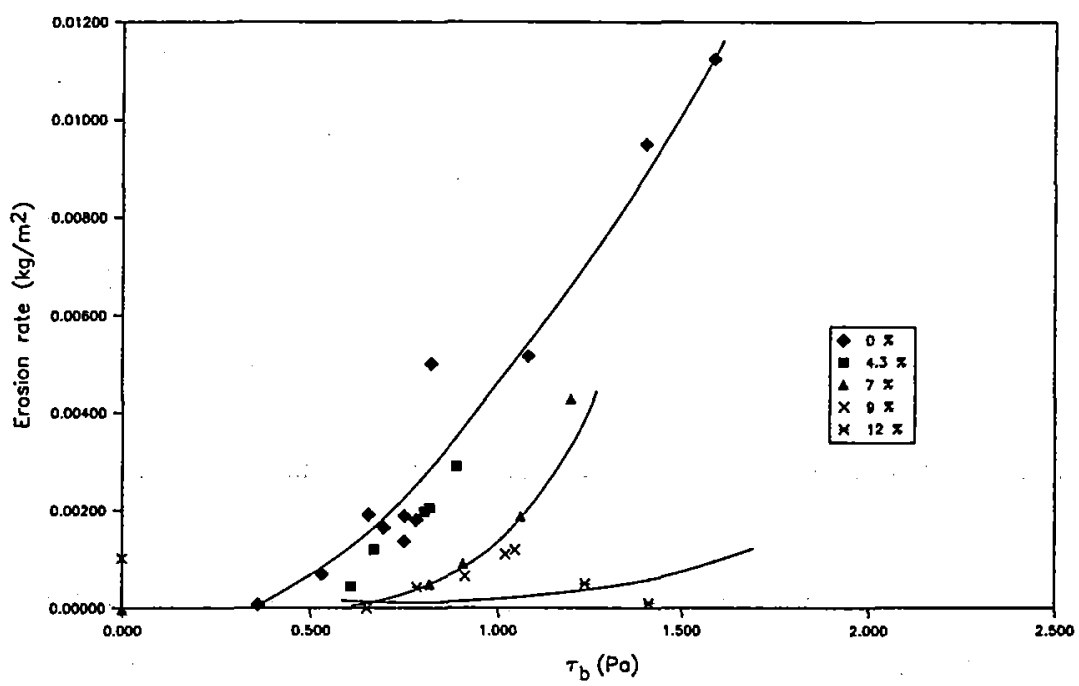

Figure 4.9: Erosion rates as a function of bed shear stress for montmorillonite mixtures. 


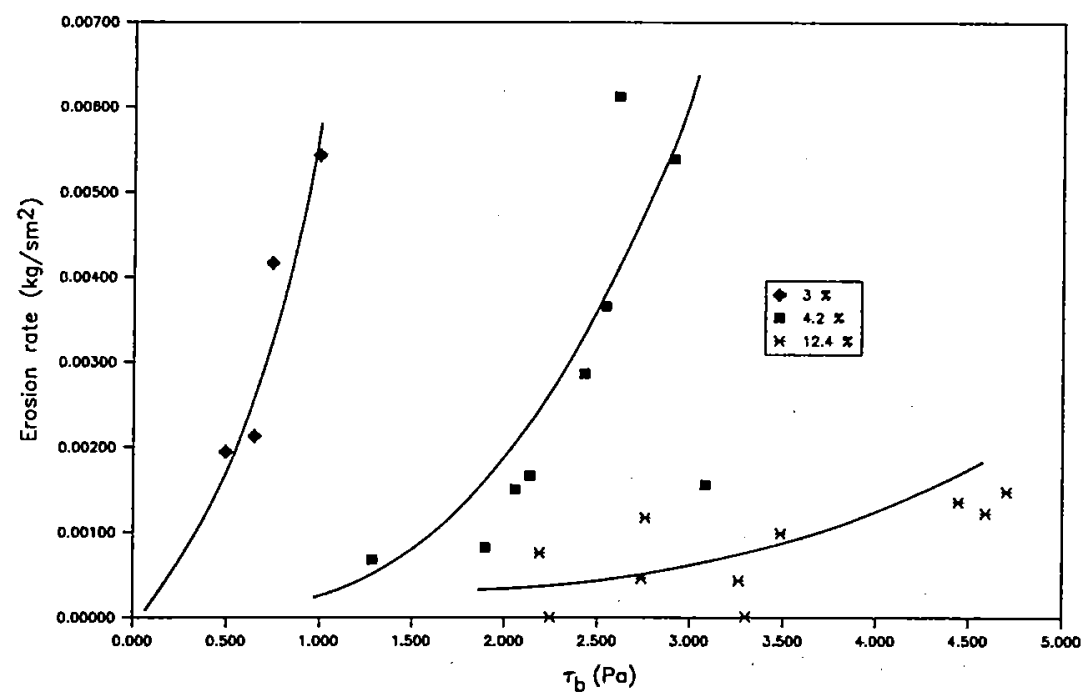

Figure 4.10: Erosion rates as a function of bed shear stress for kaolinite mixtures.

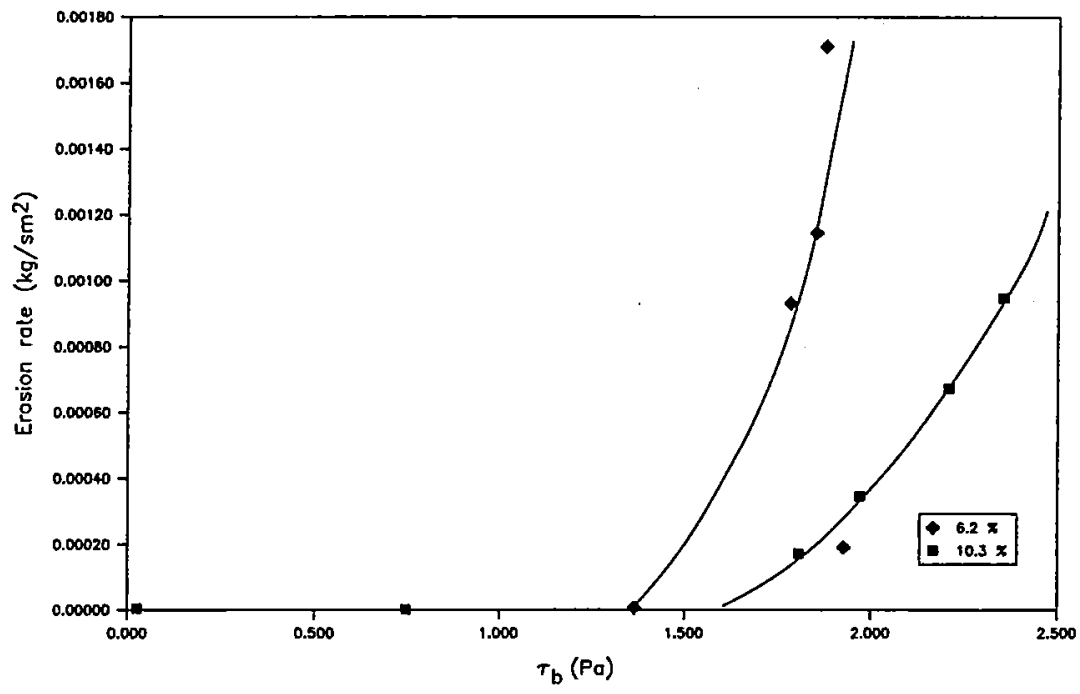

Figure 4.11: Erosion rates as a function of bed shear stress for mud1 mixtures.

To summarize, the erosion resistance of a mixture, increases with amount of fine cohesive material in the mixture and with its density and consolidation time. However, the type of cohesive sediment used has also a significant impact. 
For each of the encountered modes of erosion ( $\$ 4.3 .2)$ and for the different types of mixtures, the relation between measured erosion rates and bed shear stresses is studied in detail and the applicability of existing formulas ( $§ 2.3 .2)$ is verified.

\section{A. Cohesionless mixtures}

From the observations of bed forms and erosion patterns during the experimental runs, the following mixtures are defined as cohesionless: montmorillonite mixtures containing less than 7 to $8 \%$ fines and mud and kaolinite mixtures with less than about $4 \%$ fines. Because of the appearing ripples and dunes during the erosion process, only part of the shear exercised by the flow, $\tau_{b}{ }^{\prime}$, is used to transport the sediments. The sediment transport is calculated as the slope of the cumulated bed load, collected in the sediment trap, plotted as a function of time. Since the sediment bed has uniform properties, the cumulated bed load increases linearly in time or the bed load transport is constant, as long as the erosion does not become excessive and induces non uniform flow conditions. Because the fine fraction will be washed out of the sediment surface, also some sediment is transported in suspension. But this is only a very small quantity -the mixtures contain a very small amount of fines- and hence, these concentrations are hard to measure accurately by sampling. The suspended solids concentrations are of the order of magnitude of the possible accuracy of the filtration technique used, i.e., $0.5 \mathrm{mg} / \mathrm{l}$.

When the dimensionless sediment transport data of all these experiments are plotted versus the dimensionless excess shear stress, a good agreement with the experimental sand transport data is found (Figure 4.12). In fact equation (4.1), derived for sand only, can be used to predict the sediment transport of these cohesionless mixtures as well. Only for the mud2 mixture the measured transport rates are about twice as high. A slightly lower bed density or irregularities in the bed may be the reason for this discrepancy. In general this analysis shows that for low amounts of cohesive sediment in the mixture, the presence of the clay or mud does not inhibit the sand transport in any way, although the erosion resistance might have changed. 


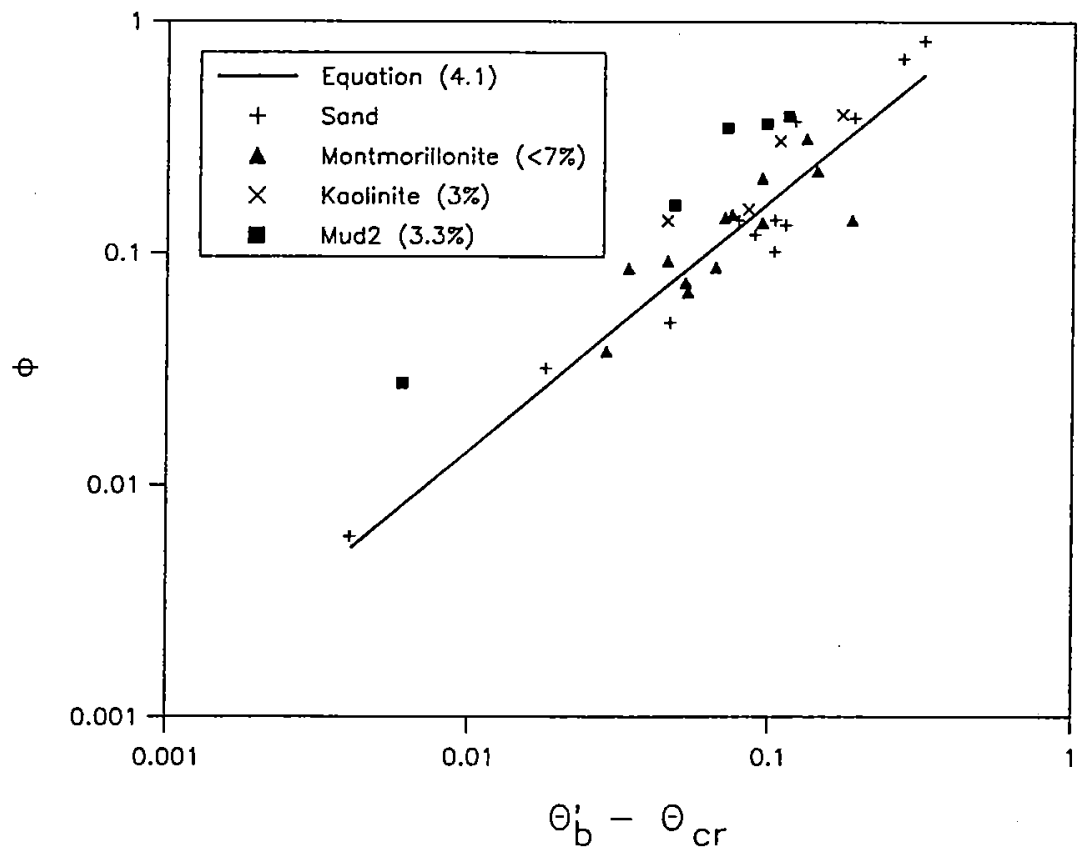

Figure 4.12: Measured bed load transport rates for the cohesionless mixtures.

\section{B. Cohesive mixtures}

As a result of the observation of the erosion process, the majority of mixtures containing a higher amount of cohesive material than the cohesionless mixtures are defined as cohesive mixtures ( $\S$ 4.3.2). Only for the montmorillonite mixtures a transitional type exists. Most of the encountered cohesive erosion processes are typically mass erosion. But during some experiments indications of the occurrence of surface erosion can be seen. E.g., after some of the experiments on mud and kaolinite mixtures, the sediment surface appeared to be undulated, one of the typical aspects of surface erosion.

Two equations exist to formulate the surface erosion process. For a soft and mostly stratified bed, equation (2.43) can be applied. For more dense and homogeneous beds equation (2.44) is more appropriate. This last equation is also used to describe mass erosion. 
For each experiment the measured erosion rates will be expressed as a function of the measured excess shear stress. By regression analysis the applicability of both equations to model the experimental data will be verified.

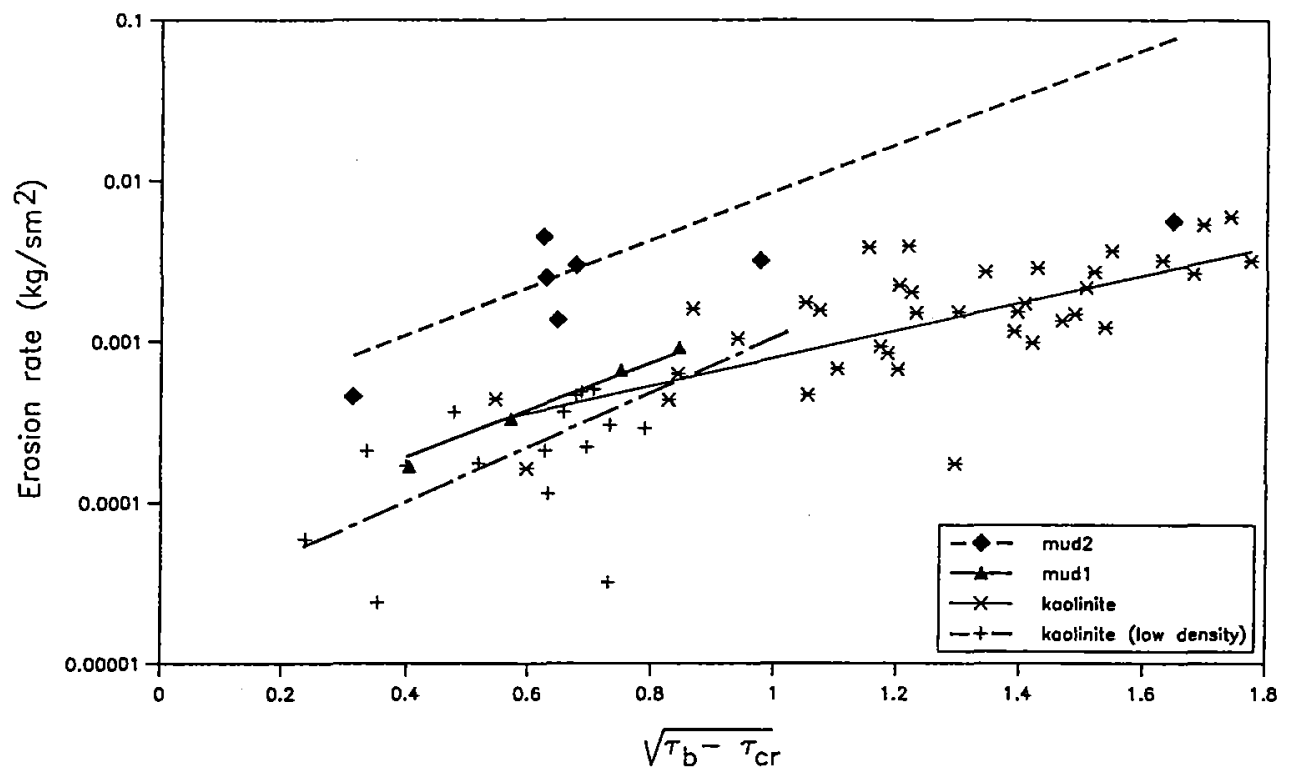

Figure 4.13: Comparison between measured erosion rates and surface erosion equation (2.43).

Table 4.2: Experimental coefficients for surface erosion (equation (2.43)).

\begin{tabular}{l|r|r|r}
\hline \hline Mixture type & $\mathrm{a}\left(\mathrm{m} / \mathrm{N}^{1 / 2}\right)$ & $\mathrm{E}_{\mathrm{f}}\left(\mathrm{kg} / \mathrm{sm}^{2}\right)$ & $\mathrm{r}$ \\
\hline Kaolinite & 1.986 & $0.1110^{-3}$ & 0.94 \\
Kaolinite (low density) & 3.820 & $0.0210^{-3}$ & 0.89 \\
Mud1 & 3.398 & $0.0510^{-3}$ & 0.98 \\
Mud2 & 3.419 & $0.2810^{-3}$ & 0.92 \\
\hline
\end{tabular}

Through data analysis, the coefficients a and $E_{f}$ for equation (2.43). are calculated. These coefficients are brought together in Table 4.2, the last column gives the regression coefficient. The experimental data and equation (2.43) are plotted in Figure 4.13 for the kaolinite and the mud mixtures. The data for the low density montmorillonite mixtures are not included, since the 
agreement between data and equation is very poor, i.e., regression coefficient around 0.7 . Equation (2.43) is not applicable in this case.

In Table 4.3 from Mehta (1988) an overview is given of the coefficients a and $E_{f}$ found by other researchers studying surface erosion.

Table 4.3: Coefficients for surface erosion (equation (2.43)), from Mehta (1988).

\begin{tabular}{l|l|r|r}
\hline \hline Sediment & Investigator(s) & $\mathrm{a}\left(\mathrm{m} / \mathrm{N}^{1 / 2}\right)$ & $\mathrm{E}_{\mathrm{f}}\left(\mathrm{kg} / \mathrm{sm}^{2}\right)$ \\
\hline Bay mud & Partheniades & 8.3 & $0.6710^{-7}$ \\
Lake mud & Lee & 8.3 & $0.7010^{-6}$ \\
Kaolinite (tap water) & Parchure and Mehta & 18.4 & $0.8310^{-6}$ \\
Kaolinite (salt water) & Parchure and Mehta & 17.2 & $2.3310^{-6}$ \\
Estuarial mud & Villaret and Paulic & 7.9 & $8.8310^{-6}$ \\
\hline \hline
\end{tabular}

Figure 4.13 shows that the surface erosion equation agrees reasonably well with the measured data, especially for the kaolinite and mudl mixtures. But if the coefficients in Table 4.2 are compared to the order of magnitude suggested in literature (Table $4.3, \mathrm{E}_{\mathrm{f}} 10^{-5}$ to $10^{-7} \mathrm{~kg} / \mathrm{sm}^{2}$ ), it becomes clear that only the low density kaolinite mixtures and the mud1 mixtures fit in this range, for the other mixtures the floc erosion rate $\left(E_{f}\right)$ is an order of magnitude higher. This comparison together with the visual observations lead to the conclusion that in this case the erosion process is mass erosion.

Parchure and Mehta (Table 4.3) found floc erosion rates of $0.810^{-6}$ for pure kaolinite in tap water, which is still much smaller than the values we found for low density kaolinite mixtures. The presence of the large sand fraction has a significant impact on the erosion process.

As mentioned before equation (2.44), i.e., a first order approximation of equation (2.43) can be used to describe surface erosion as well as mass erosion, depending on the magnitude of the coefficient $E_{m}$. Table 4.4 from Mehta (1988) gives an overview of erosion constants for surface erosion found by other researchers. 
Table 4.4: Coefficients for equation (2.44) for surface erosion from (Mehta 1988).

\begin{tabular}{l|l|r}
\hline \hline Sediment & Investigators & $\mathrm{E}_{\mathrm{m}}$ \\
\hline Yolo loam $\left(9.5^{\circ} \mathrm{C}\right)$ & Ariathurai and Arulanandan & $1.3810^{-3}$ \\
Yolo loam $\left(18^{\circ} \mathrm{C}\right)$ & Ariathurai and Arulanandan & $1.6510^{-3}$ \\
Yolo loam $\left(23^{\circ} \mathrm{C}\right)$ & Ariathurai and Arulanandan & $2.5010^{-3}$ \\
Yolo loam $\left(42^{\circ} \mathrm{C}\right)$ & Ariathurai and Arulanandan & $4.1710^{-3}$ \\
Estuarial mud & Villaret and Paulic & $1.6210^{-5}$ \\
Bay mud & Villaret and Paulic & $4.6710^{-5}$ \\
\hline
\end{tabular}

Again by regression analysis, our data are fitted to equation (2.44) and values for $E_{m}$ are calculated. For some mixtures a better agreement is obtained including an exponent $\alpha$ in the equation:

$$
E=E_{m}\left(\frac{\tau_{b}-\tau_{c r}}{\tau_{c r}}\right)^{\alpha}
$$

Table 4.5: Coefficients for equation (4.4).

\begin{tabular}{l|r|c|c}
\hline \hline Mixture type & $\mathrm{E}_{\mathrm{m}}\left(\mathrm{kg} / \mathrm{sm}^{2}\right)$ & $\alpha$ & \multicolumn{1}{c}{$\mathrm{r}$} \\
\hline Montmorillonite (upper limit) & $12.710^{-3}$ & 1.0 & - \\
Montmorillonite (lower limit) & $0.1210^{-3}$ & 1.0 & - \\
Montmorillonite (low density, 6.5\%15.9\%) & $3.7310^{-3}$ & 1.839 & 0.86 \\
Montmorillonite (low density, 20\%) & $0.1610^{-3}$ & 1.181 & 0.85 \\
Mud1 (10.3\%) & $1.310^{-3}$ & 1.144 & 0.99 \\
Mud2 & $2.010^{-3}$ & 1.0 & 0.75 \\
Kaolinite & - & - & - \\
Kaolinite (low density) & $1.810^{-3}$ & 1.0 & 0.75 \\
\hline \hline
\end{tabular}


The obtained values for $E_{m}$ and $\alpha$, together with the regression coefficient, are presented in Table 4.5. For surface erosion $\mathrm{E}_{\mathrm{m}}$ normally falls between $10^{-5}$ and $10^{-3} \mathrm{~kg} / \mathrm{sm}^{2}$. Higher values of $\mathrm{E}_{\mathrm{m}}$ indicate mass erosion. For most mixtures $\alpha$ is close to 1 , only for the low density montmorillonite mixtures containing 6.5 and $15.9 \%$ fines, $\alpha$ equals 1.8 . This irregular behaviour was also encountered in the measured critical shear stresses (Figure 4.6) and may be due to variations in density and mixture composition throughout the bed.

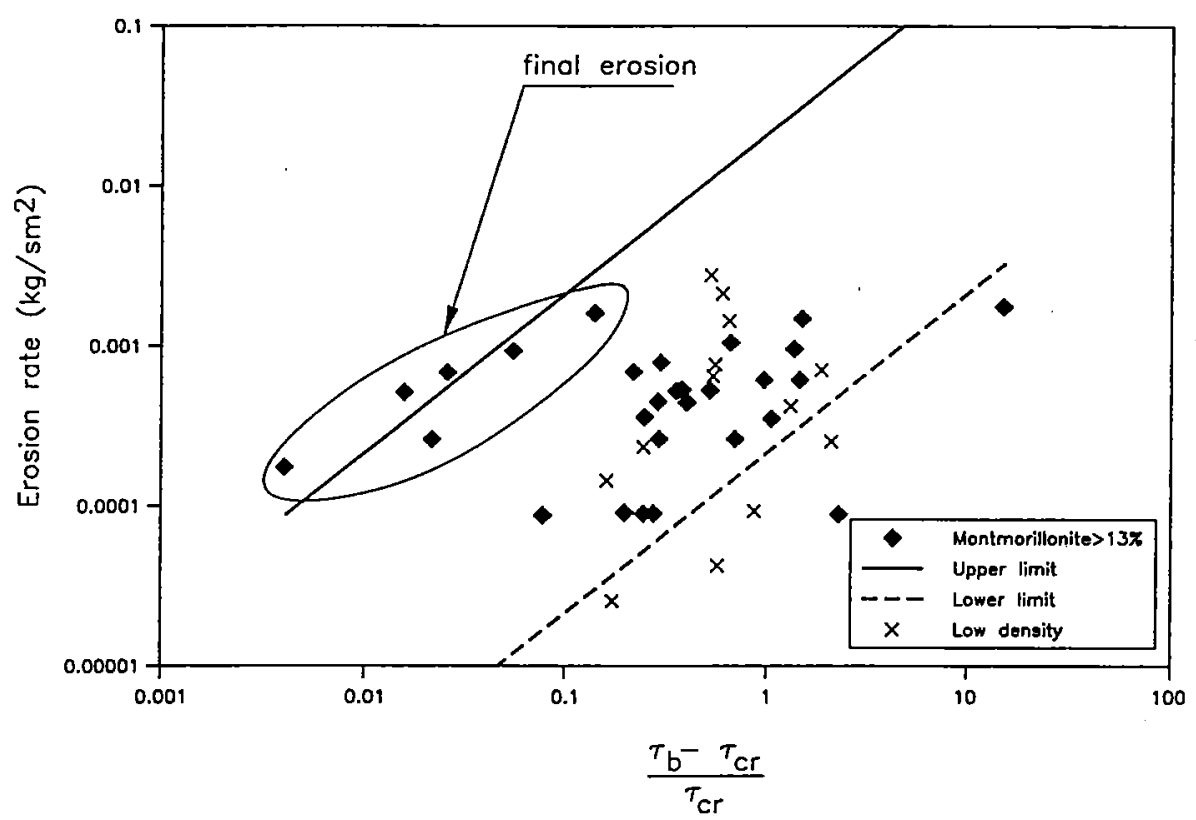

Figure 4.14: Measured erosion rates for the montmorillonite mixtures.

For the high density montmorillonite mixtures 2 sets of coefficients are given. When all the data are plotted together (Figure 4.14) they fall between an upper and lower limit, as indicated in Table 4.5, for which the erosion constant differs by more than an order of magnitude. When the data are closely analysed, two trends exist (Figure 4.14). A high excess shear stress is needed to start the erosion process at some isolated spots. The erosion is not continue and hence; the measured erosion rates are very small. The data are scattered; no unique relation seems to exist between the erosion rate and the corresponding dimensionless excess shear stress. This phase represents the erosion of the previously described resistant top layer. Further increase in flow 
velocities results in a massive erosion; large pieces of soil are removed from the bed; the measured erosion rates are very high. The bulk shear strength of the bed material is reached and erosion rates increase linearly with the dimensionless excess shear stress, according to equation (2.44) using the upper limit coefficients from Table 4.5. The magnitude of $E_{m}$ indicates that the erosion is indeed mass erosion. A groove near the centre-line of the flume results. The massive erosion and destruction of the bed causes a sudden drop in the shear stresses (calculated using the measured slope of the energy line, $S_{e}$ ) although the discharge was increased. The erosion experiment was stopped at this point. The above described erosion process is similar to the processes encountered when a cohesive sediment is sheared in a rotating cylinder viscosity metre, e.g., Brookfield. A high 'yield' stress is needed to start the process of shearing, but once the interparticle-bonds are broken a smaller shearing force is needed to continue the movement. The experimental data for the low density montmorillonite mixtures are included in the same graph (Figure 4.14). The data fall in between the same borders. The coefficients $E_{m}$ lead to believe that the encountered erosion process is again mass erosion. The difference between the two sets of low density montmorillonite mixtures is attributed to differences in bed density.

Equation (2.44) does not perform well for high density kaolinite mixtures. For these mixtures the following regression formula gave the best fit with the experimental results $(r=0.85$, for mixtures containing more than $3 \%$ fines) as plotted in Figure 4.15:

$$
E=0.00086\left(\tau_{b}-\tau_{c r}\right)^{1.106}
$$

The erosion of the low density mixtures is considered to be surface erosion. Since the sediment bed has uniform properties equation (2.44), being a first order approximation of equation (2.43) for homogeneous sediment beds, can be used to model these data as well (see Table 4.5). However, the previously derived relation (equation (4.5)) for the high density mixtures describes the measured erosion rates even better (Figure 4.15). In other words, the erosion rates for kaolinite mixtures of varying density and mixture composition can all be represented by the same equation (4.5). 


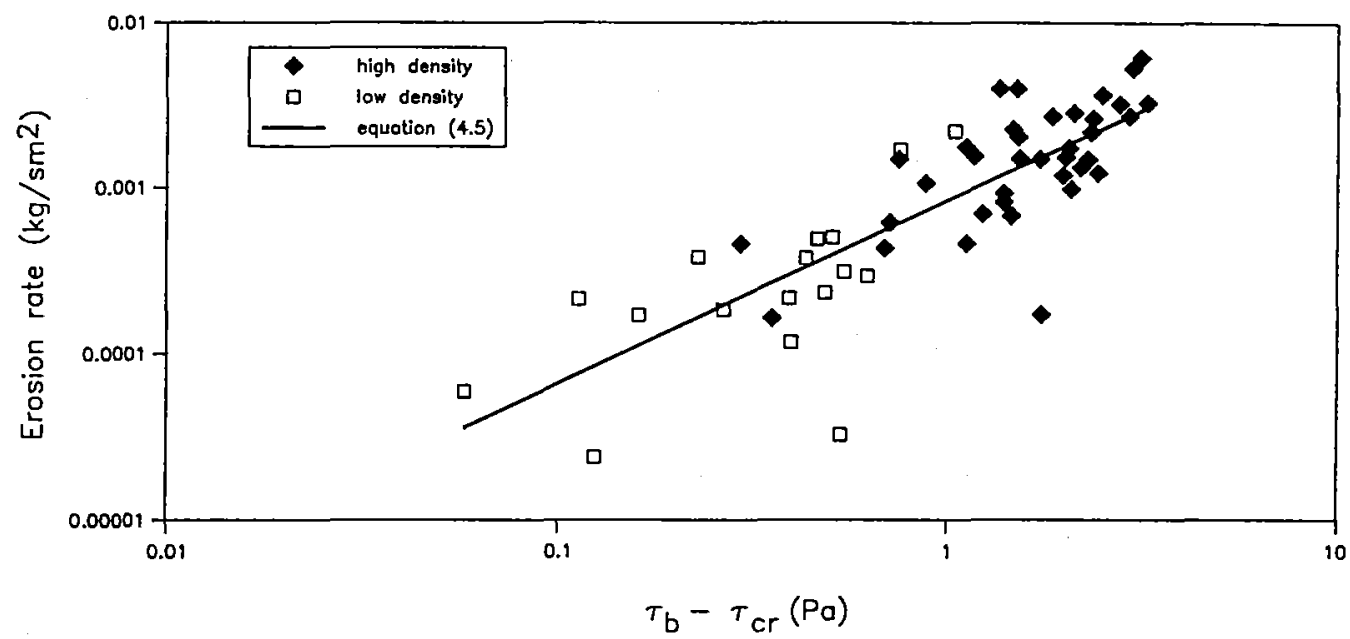

Figure 4.15: Measured erosion rates for the kaolinite mixtures.

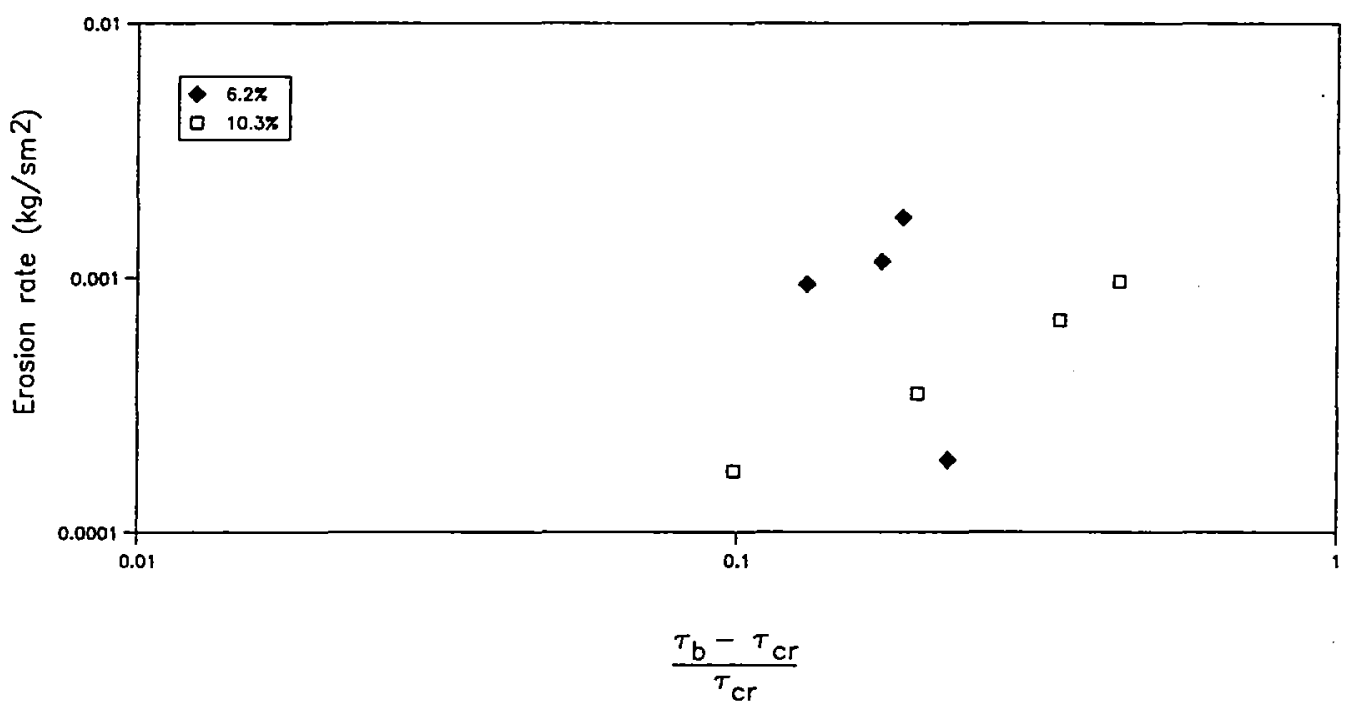

Figure 4.16: Measured erosion rates for the mudl mixtures.

The erosion process of the mud mixtures is not so unambiguous. The data for mudl could indicate surface erosion, however this is not certain. The application of equation (2.44) by regression analysis shows a lot of scatter of the data (Figure 4.16). The mud does not have very uniform and constant properties. Organic content, mineralogical and chemical composition, all these parameters vary for the different mixtures, because the mud fractions were taken from different barrels that are not completely identical and because the properties change in time. 
Therefore no unique relation for all mud mixtures could be derived. On the other hand the observed erosion patterns and measured erosion properties do not differ a lot from the observations and measurements made on clay mixtures.

\section{Transition type}

For the montmorillonite mixtures the transition was very pronounced. Mixtures containing between 7 and $13 \%$ fines showed a very irregular behaviour, as explained in $\S 4.3 .2$. Plotting e.g., the data of these experiments on the same graph as the data of the cohesionless mixtures, Figure 4.17 , it is clear that these points do not follow the same trend. In fact no clear relation between the measured sediment transport and the bed shear stress is found. However, for a similar excess shear stress the measured sediment transport is lower than for the cohesionless mixtures. This is the effect of the increased clay content of the mixtures.

For the other types of mixtures (kaolinite, mud) no clear transition phenomenon is encountered during the tests.

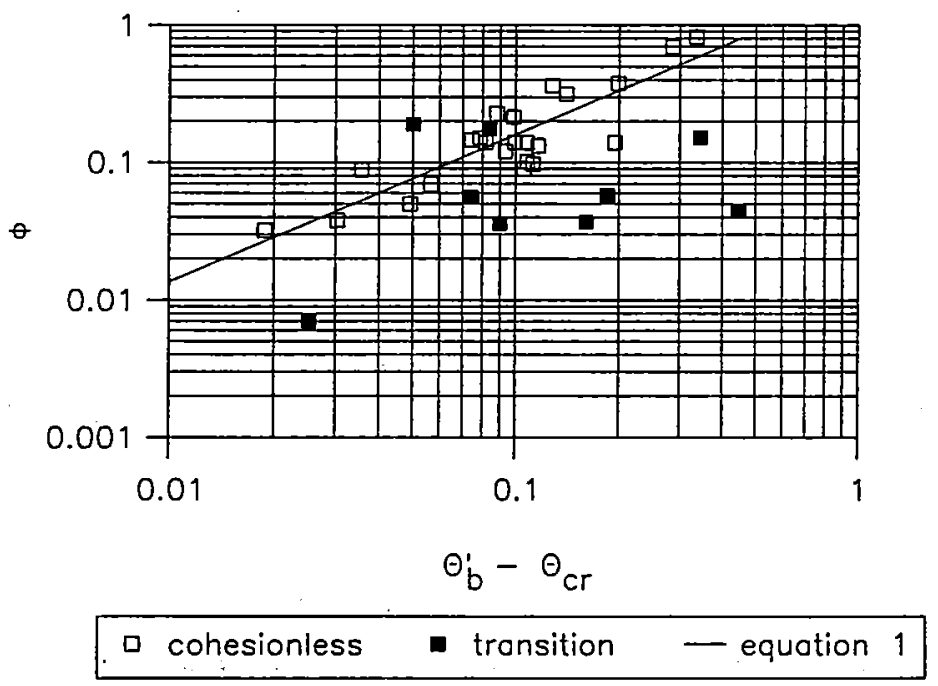

Figure 4.17: The transition zone for the montmorillonite mixtures. 


\subsection{Erosion of deposited mixtures}

\subsubsection{Aim of the experiments}

As explained in Chapter $3(\$ 3.5)$, the second type of erosion tests was performed on deposited beds. In this way the natural processes, responsible for the formation of a sediment bed, are simulated. In estuaries the sediment bed is eroded during a storm or during periods of high flow energy and the sediments settle out of the suspension under quiescent flow conditions. In combined sewer systems thunderstorms are responsible for major erosion events. After the passage of the hydrograph, the suspended sediments deposit again. These kind of processes result in the formation of a highly stratified sediment bed. In estuaries the succession of tidal cycles leads to the formation of consecutive layers in the bed, whereas in a combined sewer, usually one soft, highly stratified layer is found on top of a more dense "permanent" bed. The layered bed experiments are carried out to study these processes: using a settling tank the formation of the bed is simulated and afterwards the erosional behaviour of that bed is examined.

Understanding the formation of a stratified, layered bed and especially the influence of the sand content of the sediment on the formation process is the first aim of these experiments. The thickness of the layers and the measured density profiles will be studied and compared for the different experiments.

Secondly, the erosion of a layered bed will be followed and again the accent will lie on the role of the sand fraction in that process. In this part of the research the erosion resistance, the mode of erosion and the measured erosion rates are discussed.

A set of 8 erosion experiments is performed on two sets of Scheldt mud mixtures with varying sand content. The compositions of these mixtures can be found in Table 4.6. To check the performance of the settling tank and the settling column, 4 preliminary experiments were carried out. In these experiments mixtures with montmorillonite and kaolinite were used. The performance of the equipment and the followed experimental procedure was satisfactory. The 
results of the clay mixture experiments are very similar to the results of the mud mixture tests. Some of these results are included in the following paragraphs.

Table 4.6: Input conditions for the layered bed formation process.

\begin{tabular}{l|r|r|r|r}
\hline \hline Name & Sand content (\%) & Initial density $\left(\mathrm{kg} / \mathrm{m}^{3}\right)$ & Number of layers & Mud type \\
\hline $\mathrm{J} 1$ & 24.6 & 1006 & 4 & mud2 \\
$\mathrm{J} 2$ & 18.1 & 1005 & 3 & $\mathrm{mud} 2$ \\
$\mathrm{~J} 3$ & 20.7 & 1005 & 3 & $\mathrm{mud} 2$ \\
$\mathrm{~J} 4$ & 26.6 & 1005 & 3 & $\mathrm{mud} 2$ \\
$\mathrm{~J} 5$ & 28.7 & 1005 & 3 & $\mathrm{mud}$ \\
$\mathrm{J} 6$ & 40.8 & 1006 & 5 & $\operatorname{mud}$ \\
$\mathrm{J} 7$ & 46.2 & 1006 & 5 & $\operatorname{mud} 3$ \\
$\mathrm{~J} 8$ & 53.1 & 1006 & 5 & $\operatorname{mud} 3$ \\
\hline \hline
\end{tabular}

\subsubsection{Bed structure}

To study the formation and the structure of the stratified bed without destructing it, a settling column is used. In this column the same procedure of introducing the mixture slurry is followed as in the settling tank in order to create a similar bed as in the flume. The perspex column is transparent so that the bed structure can be inspected and the layer thicknesses can be measured. With a gamma-densimeter the density profile at the beginning of the erosion experiment is measured. The used equipment and the experimental procedure are discussed in detail in Chapter 3.

Before presenting the experimental results on layer thicknesses (B) and measured density profiles (C), in a first part (A) some general information is given on settling and consolidation of mud/sand mixtures. 


\section{A. Settling and consolidation of mud/sand mixtures}

The following information on settling and consolidation is based on experimental research carried out in the framework of the MAST G8M Coastal Morphodynamics programme, Topic 4: Cohesive sediments (Torfs et al. 1995). The experiments were carried out at the Hydraulics Laboratory of the K.U.Leuven (Huysentruyt 1994, Toorman et al. 1993) and at HR Wallingford ltd. (Ockenden et al. 1988, Williamson et al. 1992). During these "single shot" experiments the settling and consolidation of at once dumped mixtures of mud and sand was studied.

When a mixture of mud and sand settles out of a suspension, mostly segregation occurs. Due to the differences in shape and density of the particles, they have different settling velocities. Therefore, sand particles settle quicker and form a separate layer on the bottom. However, when the mud forms a continuous structure, this matrix can prevent sand from falling through and hence, prevent segregation. A structure will be formed when the input rate of the mud suspension in the settling column is slow enough, or when the initial density of the suspension is high enough, i.e., above the gel point. The gel point increases with increasing sand content of the mixture. The mud type is another important factor that determines whether the mud is able to hold (some) sand within its matrix.

The degree of segregation is limited. Above a certain amount, depending on the mud type, adding more sand to the mixture seems to have no additional effect on the thickness of the resulting sand layer.

Adding sand to mud increases its settling and consolidation rates. This in turn results in higher densities. This process is also limited: adding more sand to the mixture above a certain percentage will no longer speed up the process.

When segregation occurs, the top layer of the sediment deposit is more or less sand-free. But its structure and density have changed (increased) by the passage of the sand. Two possible reasons are stated for this increased density. On their way down the sand particles take the finest particles of top layer with them, leaving the larger denser silts behind. Another explanation is that the falling sand particles create drainage paths in the muddy layer, that in turn enhance the consolidation of that mud layer. When too much sand is added, these little drainage paths loosen the structure so that the effect is limited. 


\section{B. Layer thickness}

In our experiments a mixture of mud and sand is dumped at half a day intervals. In this way different layers are formed. Plate $2 \mathrm{a}$ shows a typical stratified bed in the settling column. The picture is taken for a preliminary experiment using a montmorillonite mixture. The different layers are very clear and their dimensions can easily be measured. In most cases the first few millimetres of the top layer have a completely different aspect. It looks like a thin film covering the deposit. This thin top layer has a fluffy structure, like a mousse. This type of soft top layer has also been encountered in the field (Van Dam 1982) and can possibly be attributed to diffusion of oxygen from the water to the sediment deposit. Colour differences in each layer, indicate that (part of the) sand falls through each layer and accumulates at the base of the layer. So each layer consists of a muddy part on top of a sand layer.

For every experiment, the mean layer thickness is calculated. In these calculations the thickness of the top layer is not taken into account, because its dimensions are not unambiguous. The exact border between clear water and mud is harder to define visually than the interface in between two layers. Moreover, if the consolidation of the previous layers is not completed before the dumping of the last one, this last layer gets thicker due to the expelled water of the underlying layers, that are still consolidating. This is especially the case for low sand content mixtures. For high sand content the settling and consolidation rates are higher as well.

Figure 4.18 gives an overview of the average layer thickness for every experiment as a function of the percentage sand in the mixture. The results of the preliminary experiments are also included in this graph.

For all the experiments the average layer thickness seems to be decreasing as a function of sand content (Figure 4.18). But, the type of sediments can be partly responsible for that. At the same input conditions, the thickness of the mud2 layers is higher than those of mud 3 mixtures, even for similar sand contents. To fill the sediment box in the flume three layers of mud 2 mixture are needed or five mud3 layers.

If only the data for mud 2 are considered, the decrease of layer thickness with increasing sand content is a lot less pronounced. In fact an asymptotic value of the layer thickness is reached and further adding of sand does not change the layer thickness any further. For the mud 3 mixtures 
this limit has not been reached. The three experiments indicate a linear decrease of the layer thickness with sand content.

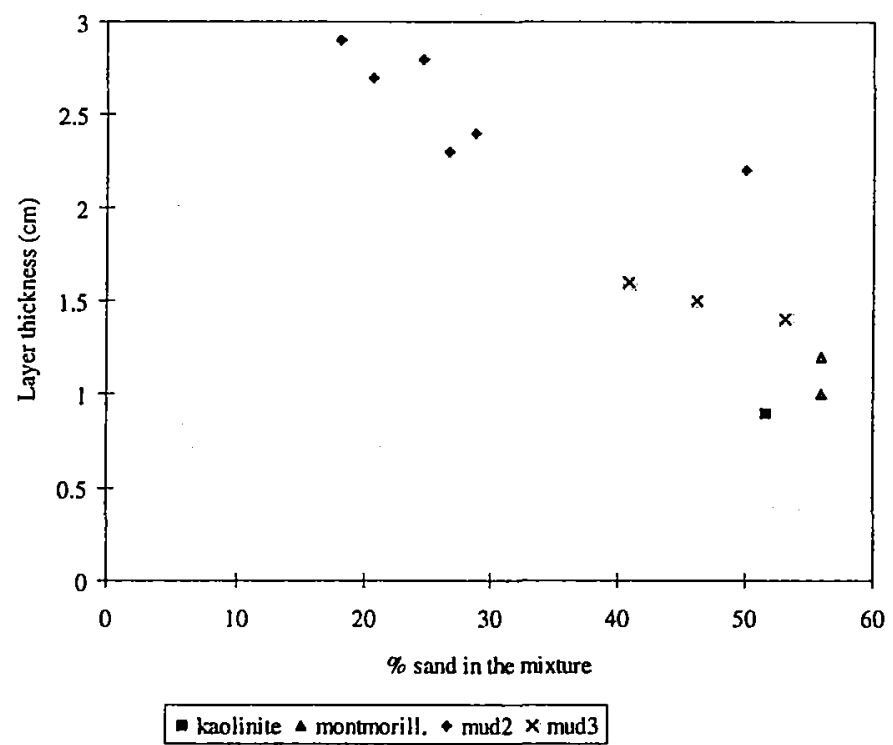

Figure 4.18: Mean layer thickness as a function of sand content.

An extensive set of consolidation experiments in our laboratory with amongst others mud2 (Huysentruyt 1994) showed that the settling behaviour is only affected by the addition of sand up to a certain maximum percentage of sand added. In the case of mud 2 an addition of $10 \%$ and more sand does not change the settling behaviour any more. Segregation takes place and the thickness and density peak of the bottom layer remain the same. An addition of $10 \%$ sand means a total sand content of about $25 \%$ sand (the natural sand content of mud 2 is $15 \%$ ), the results of Figure 4.18 seem to confirm this limit.

Attention should be paid to the fact that our comparisons are made at a certain point in time (a few hours after the dumping of the last layer). Huysentruyt (1994) and also Williamson et al. (1992) showed that mud alone settles and consolidates slower than mud with extra sand, so time effects can be important. The decreasing layer thickness could be due to the increased consolidation rate only. If consolidation would continue, it is possible that eventually the same layer thickness is reached. This was the case in the experiments of Williamson et al. (1992). 


\section{Density profiles}

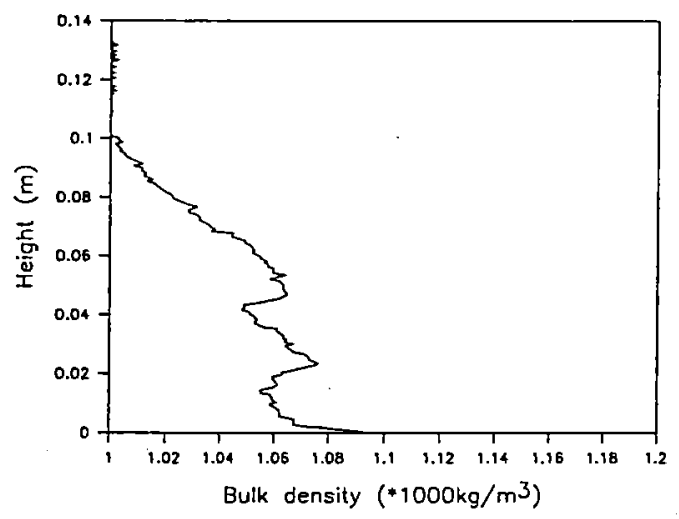

Figure 4.19: Density profile for experiment J5, Figure 4.20: Density profile for experiment J6, mud 2 mixture, sand content $29 \%$.

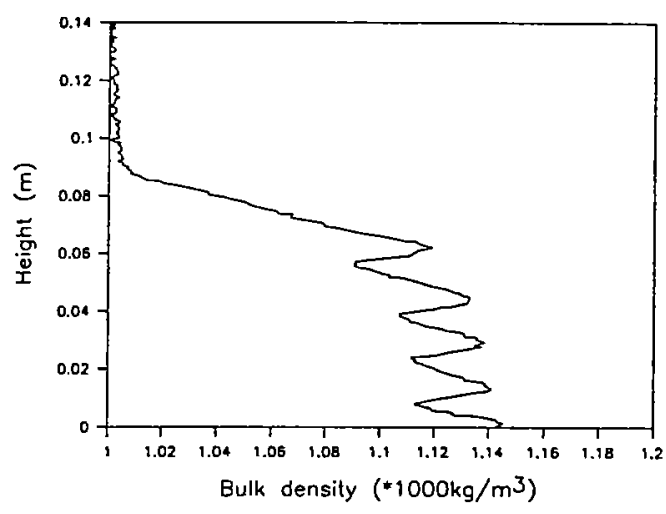

mud3 mixture, sand content $41 \%$.

Not only from the observations of the settling columns but also in all the measured density profiles the stratified structure of the bed is very clear. Two typical examples of measured density profiles are given in Figure 4.19 for a mud2 mixture and Figure 4.20 for a mud3 mixture. The peaks in each profile indicate the layer interfaces. These peaks are the result of segregation and accumulation of sand at the bottom of each layer. Probably a small part of that sand intrudes in the previous layer. But it is clear that in the small period of time in between two consecutive inputs, i.e., only a few hours, the previous muddy layer already developed enough structure to carry the next denser layer. Experiments on pure mud (Williamson et al. 1992) or kaolinite (Huysentruyt 1994) dumped in layers also showed a peaked density profile. This means that sand accumulation is not the only: explanation for those peaks. The peaks in the density profile can also be the result of the segregation of large cohesive flocs at densities smaller than the gel point (Toorman et al. 1993). In our case visual inspection of the settling columns proves that the density peaks are caused by sand segregation. 
Normally a density of about $1.4 \mathrm{~kg} / \mathrm{dm}^{3}$ is expected for pure, loosly packed sand but the measured peak densities are a lot lower. This may be an indication that some mud is mixed with the sand. On the other hand, the sand layer is very thin. If all the sand would accumulate at the bottom of a layer, the sand peak would be about $2 \mathrm{~mm}$ thick for a mixture with a sand content of $30 \%$. However, some sand gets trapped inside the mud and some sand may intrude in the previous layer. Hence, the segregated sand layer is of the order of $1 \mathrm{~mm}$, which is less than the vertical resolution of the gamma-densimeter. So it is very likely that the actual density peak is missed (or averaged out) by the density probe.

The two density profiles in Figures 4.19, 4.20 also demonstrate that the top layer is much thicker than the other layers, especially for the mud2 mixtures with the lowest sand content. The consolidation of the underlying layers and the water being expelled from those layers disturbs the consolidation process of the top layer. Hence, it is hard to define the exact interface between mud and water. This transition from water to mud includes also the previously described soft top layer covering the deposit.

Looking at the shape of the measured density profiles, there is a clear difference between the experiments with mud2 (Figure 4.19) and the experiments with mud3 (Figure 4.20). In both sets of density profiles some sort of segregation is visible. The density profiles from mud 2 mixtures show a high density peak at the bottom of each layer and then a fairly uniform zone of constant density (around $1.06 \mathrm{~kg} / \mathrm{dm}^{3}$ ). Probably the sand content is fairly constant in this region as well. At the top of each layer some sort of low density peak can be seen as well. A similar feature has been reported by Edge et al. (1989).

For mud3 the density is gradually decreasing throughout the whole layer. This could indicate that in this case sand is also withheld within the mud matrix and that there is a smooth evolution of sand content over the layer thickness. Mud3 already contained a high amount of sand. This means that mud3 has a greater ability to hold sand within its matrix. Mud2 has a low natural sand content and here more (all?) sand falls through. 
The occurrence of segregation and hence, the presence of a high density sand layer depends on different factors (see $\$ 4.4 .2, \mathrm{~A}$ ). The initial density of the mixture suspension determines whether hindered settling occurs. Hindered settling can prevent the sand from falling through the mud during deposition. In the described experiments the suspension concentrations from which the sediments settled out are very small (Table 4.6), hindered settling could not take place.

A slurry can only contain a certain amount of sand within its matrix, so the sand content of the mud is certainly an important factor. This is demonstrated by the differences in the shape of density profiles between mud 2 and mud3, as explained above. In the experiments of Huysentruyt (1994) on mud2 the segregation limit was less than $10 \%$ sand added (i.e., about $25 \%$ sand content). This agrees well with our tests: the sand content in the mud2 mixtures is around $25 \%$ and segregation always occurs. Of course the initial conditions (density) in our experiments are a lot different from the initial conditions of the experiments described by Huysentruyt (1994). The matrix structure itself depends on the gel point: below the gel point no structure exists and sand can fall through. The initial densities of the mud slurries used in these experiments are smaller than the gel point.

Further the type of mud, its mineralogical and chemical composition, the organic matter, etc. determines the matrix structure of the bed as well as of the flocs in suspension. This structure determines whether sand can easily fall through or gets trapped. Also flocculation, salinity, ... are important factors (Williamson 1991), that have not been studied in this work.

When a sand layer is formed in between mud layers, the sand enhances the drainage of the mud and thus more rapid compaction will take place. This effect will probably be stronger in the larger flume than in the small column. However, no comparisons between flume and column are made, except for the total bed thickness, which is almost the same in flume and column. Another consequence of the presence of sand in the mixture is the increased density and structural strength of the mud layer.

Mud3 density profiles show higher peak densities. For the mud3 mixtures the density in a layer varies between 1.08 and $1.14 \mathrm{~kg} / \mathrm{dm}^{3}$. For mud2 (with a lower sand content) the density in a layer goes from 1.05 and $1.12 \mathrm{~kg} / \mathrm{dm}^{3}$. The higher density of the mud3 mixtures is caused by the higher sand content of these mixtures and by the faster consolidation. 


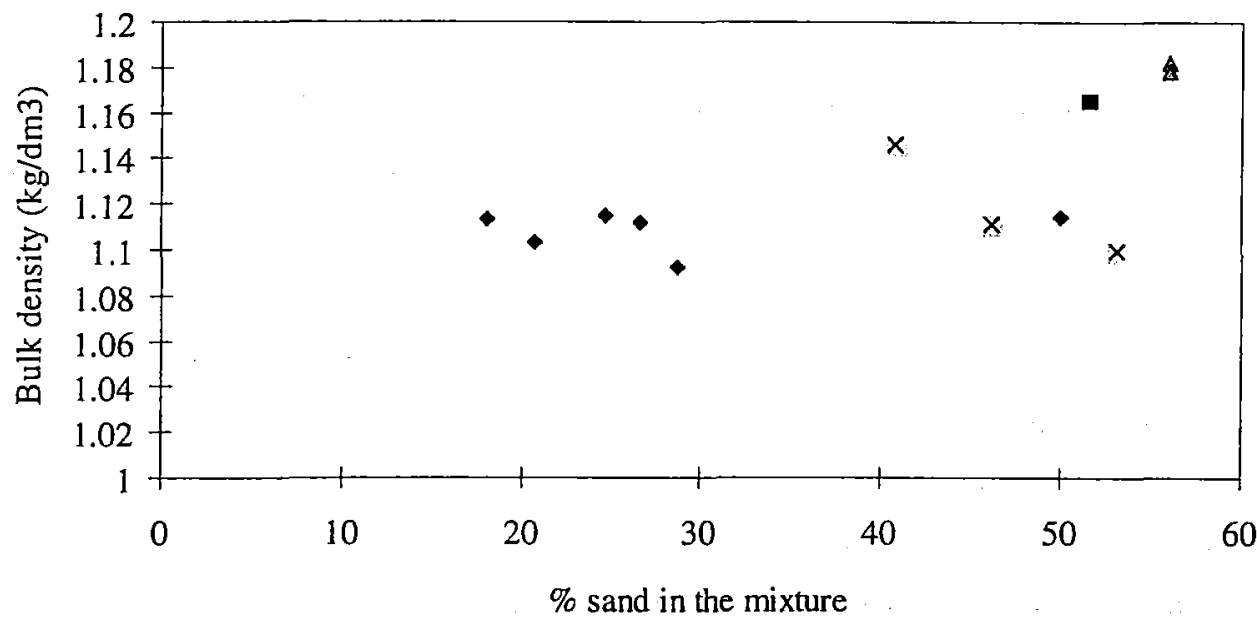

kaolinite $\Delta$ montmorillonite $\bullet \operatorname{mud} 2 \times \operatorname{mud} 3$

Figure 4.21: Peak density of the bottom layer as a function of sand content.

Hence, looking at the peak density of e.g., the bottom layer one would expect an increase of the peak density with sand content. However, the results in Figure 4.21 do not show this trend convincingly. On the contrary, for mud3 the opposite can be seen. Obviously the type of mud (e.g., organic matter) is very important and other effects besides consolidation and segregation play an important role as well. The range of applied mixture compositions for each type of mud is not wide enough to draw general conclusions; the experiments can only demonstrate some trends.

\subsubsection{Description of the observed erosion process}

The erosion of a deposited bed differs significantly from the previously described processes for homogeneous beds. These differences are not only due to the different bed structure but also the lower bed density is partly responsible for the erosional behaviour. For each of the stratified bed experiments, the erosion process is quite similar. An overview of a typical experiment is given in Figure 4.22. The discharge in the flume is increased in three steps, and for each step the 
suspended load upstream and downstream of the sediment bed and the cumulated bed load, collected in the sediment trap, are plotted.

During the first step a thin film is lifted of the bed surface and goes into suspension. This soft layer, that is also observed in the settling column, consists only of fine material. On the surface longitudinal fine lines appear. The suspended sediment concentrations are very low.

After increasing the discharge (step 2, Figure 4.22), the erosion of the first layer starts. Due to the segregation of the sand fraction, this part of the layer is mainly mud. The erosion results in suspended load. The downstream suspension concentration increases suddenly. The difference between the suspended load downstream and upstream is a measure for the amount of material eroded from the bed. This difference is proportional to the erosion rate. At the beginning, no bed load erosion occurs. The slope of the cumulated bed load during this period is zero (Figure 4.22). For the bed load, this slope is representative for the rate of erosion ( $\$ 3.7 .2)$.

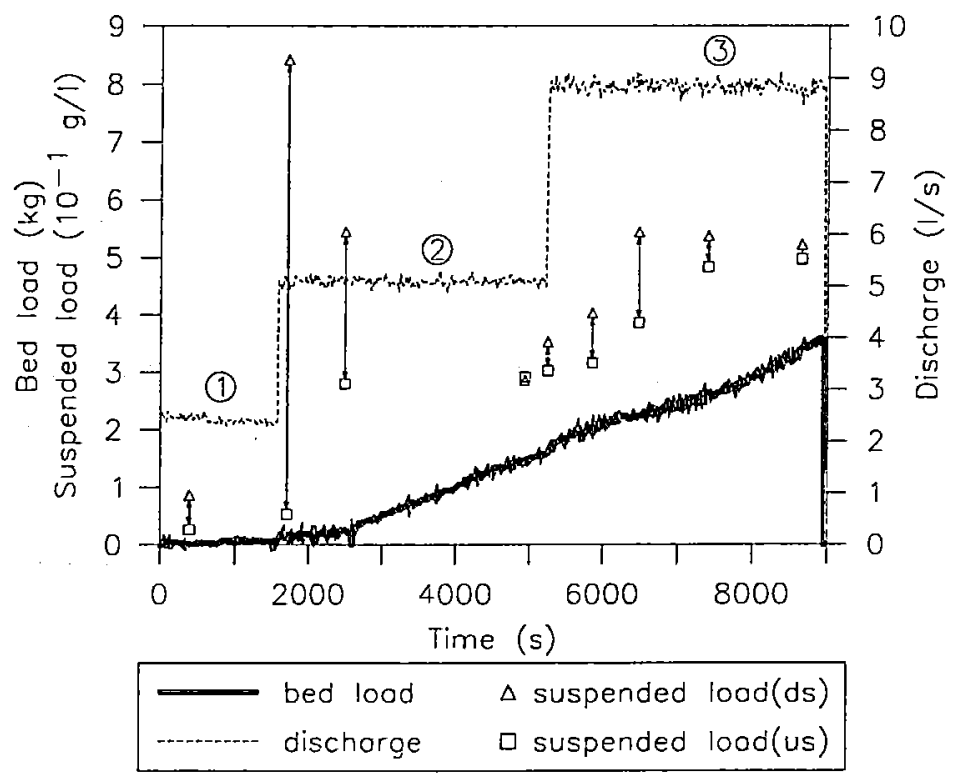

Figure 4.22: Overview of a typical erosion experiment.

After a while the mud erosion decreases, the difference between upstream and downstream concentration eventually goes to zero. However, the applied bed shear stress is still the same because the little changes in shear stress due to bed level changes are negligible. This diminution 
of the erosion can be caused by two different factors. Due to the increasing bed density with depth (see the density profiles in Figures $4.19,4.20$ ) the erosion resistance or shear strength of the mixture increases also with depth. If a layer is reached for which the shear strength is higher than the applied bed shear stress, the erosion ends. The second possibility is that a sand layer is reached. The sediments in this layer are transported mainly as bed load. Therefore, the suspended load decreases. This is what happens in this experiment. The slope of the curve of the measured bed load increases. Ripples are observed on the bed. These bed forms are moving towards the downstream end of the flume.

Increasing the discharge (step 3, Figure 4.22) increases the bed load transport of the sand until all the bed forms reach the sediment trap. Meanwhile at the upstream end of the sediment bed, the next mud layer becomes available and goes into suspension. The bed load decreases, the suspended load increases again... In this way layer by layer the sediment is eroded from the bed.

Plate $2 \mathrm{~b}$ shows a sediment bed after an erosion experiment. Over the central part of the bed one layer has been eroded. This feature is very similar to the formation of a groove during the erosion of the uniform mixtures. The influence of the side walls in a narrow flume reduces the bed shear stress near the side walls and hence the erosion as well.

For all experiments on layered sediment beds a similar sequence of suspended load and bed load transport was encountered, indicating a layer by layer erosion of the bed. Depending on the flow velocities (bed shear stresses) the finer mud fraction is transported as suspended load and the sand fraction as bed load. At sufficiently high flow velocities also the sand will eventually go into suspension.

\subsubsection{Erosion resistance and measured erosion rates}

Although the bed densities are very low, between 1.06 and $1.15 \mathrm{~kg} / \mathrm{dm}^{3}$, the sediment bed shows a significant erosion resistance. The surface density at the start of an erosion experiment varies between 1.01 and $1.05 \mathrm{~kg} / \mathrm{dm}^{3}$. This range of bulk densities is normally called fluid mud, a highly 
mobile mud suspension. But the bed seems to develop some sort of structure that enables it to withstand erosion, except for the thin film of soft material on top of the bed. For instance, Figure 4.22 shows that at the lowest discharge no significant erosion occurs. Probably this erosion resistance is caused by the presence of sand in the mixture. If sand is trapped inside the mud matrix this can alter the structure and hence the erosion resistance e.g., due to reduced permeability. However, due to segregation, the surface layer of the bed is almost sand-free. Experiments by Ockenden et al. (1988) demonstrated that the passage of sand through the mud makes the sand-free layer denser and stronger.

The shear resistance of the bed varies with the bulk density and hence with depth in the bed. During the erosion process the critical shear stress of the erodible layer varies constantly. But a shear strength profile could not be measured. In every experiment the erosion process starts with fine material going into suspension. Due to the time consuming procedure of sampling and filtering the suspended load, only a discrete and small number of samples is taken. This means that the time evolution of the erosion cannot be followed during the experiment. Also the bed level cannot be monitored. Otherwise a combination of equilibrium bed level measurements (where the erosion ended) and the corresponding applied bed shear stress could lead to a shear strength profile for the bed (Parchure et al. 1985).

In literature several empirical formulas for the calculation of the critical shear stress are given. E.g., Mehta (1988) gives the following expression for shear strength as a function of bulk density:

$$
\tau_{c r}=\zeta\left(\rho_{b}-1\right)
$$

in which the bulk density $\left(\rho_{\mathrm{b}}\right)$ is expressed in $\mathrm{kg} / \mathrm{dm}^{3}$.

For the given surface densities, between 1.01 and $1.05 \mathrm{~kg} / \mathrm{dm}^{3}$, and using $\zeta=1$ as suggested by Mehta, this would lead to critical shear stresses in the order of magnitude of $0.01 \mathrm{~Pa}$. The applied bed shear stresses are of the order of magnitude of $1 \mathrm{~Pa}$. The erosion rate is a function of excess shear stress. Since the excess shear stress calculated using equation (2.33) is very high, high erosion rates are expected, contrary to the observations. 
It is obvious that the erosion resistance depends strongly on the density. Hence, a linear function between bed density and critical shear stress for erosion, like equation (2.33), is a simple, approximate way of expressing this relation. However, the coefficient $\zeta$ needs to be determined for the kind of sediments used. This will be done by modelling the erosion rates. To predict the erosion rates of a loose stratified bed, normally equation (2.43) for surface erosion is used. Again two coefficients a and $E_{f}$ need to be determined.

The coefficients $\zeta$, a and $E_{f}$ are determined as follows: by changing the parameters in the equations the agreement between measured time evolution (some discrete points) of the erosion rate and the calculated values (continuous function of time) is optimized; i.e., the differences between the predicted and measured values are minimized. In this way the optimal coefficients can be assessed. It was assumed that the presence of the sand has a major effect on the erosion resistance of the sand-free top layer but that the mode of erosion was not significantly affected. Hence the order of magnitude of a and $E_{f}$ was chosen from Table 4.3 for surface erosion. And $\zeta$ was varied in order to fit the predictions to the measured values.

This exercise has been carried out in the framework of a masters thesis by Dauwe et al. (1995). The three coefficients have been chosen so that the calculated erosion rates agree best with the measured erosion rates for the first two steps of each experiment. At higher discharges the excessive erosion causes irregularities in the flow so that uniform flow conditions are no longer valid. This implies that only erosion rates of the muddy layer (suspended load) are modelled.

Table 4.7: Overview of the coefficients used for modelling the erosion rates.

\begin{tabular}{l|r|r|c|c|c}
\hline \hline Experiment & Mud type & Sand content & $\mathrm{a}\left(\mathrm{m} / \mathrm{N}^{1 / 2}\right)$ & $\mathrm{E}_{\mathrm{f}}\left(\mathrm{kg} / \mathrm{m}^{2} \mathrm{~s}\right)$ & $\zeta(-)$ \\
\hline J2 & mud2 & 18.1 & 18.5 & $910^{-8}$ & 27.8 \\
J3 & mud2 & 20.7 & 15 & $2.510^{-9}$ & 33 \\
J5 & mud2 & 28.7 & 12 & $2.010^{-8}$ & 37 \\
J6 & mud3 & 40.8 & 13 & $3710^{-8}$ & 18 \\
J7 & mud3 & 46.2 & 19.7 & $9010^{-8}$ & 9 \\
J8 & mud3 & 53.1 & 18.7 & $8010^{-8}$ & 9 \\
\hline \hline
\end{tabular}


An overview of the coefficients for each experiment is given in Table 4.7. For experiment $J 1$ the pressure transducers, that register the water levels upstream and downstream of the sediment section, failed; no bed shear stresses could be calculated and hence the modelling could not be carried out. No good agreement between measurements and calculations was found for experiment J4. An example of the results is given in Figure 4.23, for experiment J6. This example shows that the agreement between calculated and measured values is quite good. More accurate modelling is not possible due to the lack of measured erosion rates.

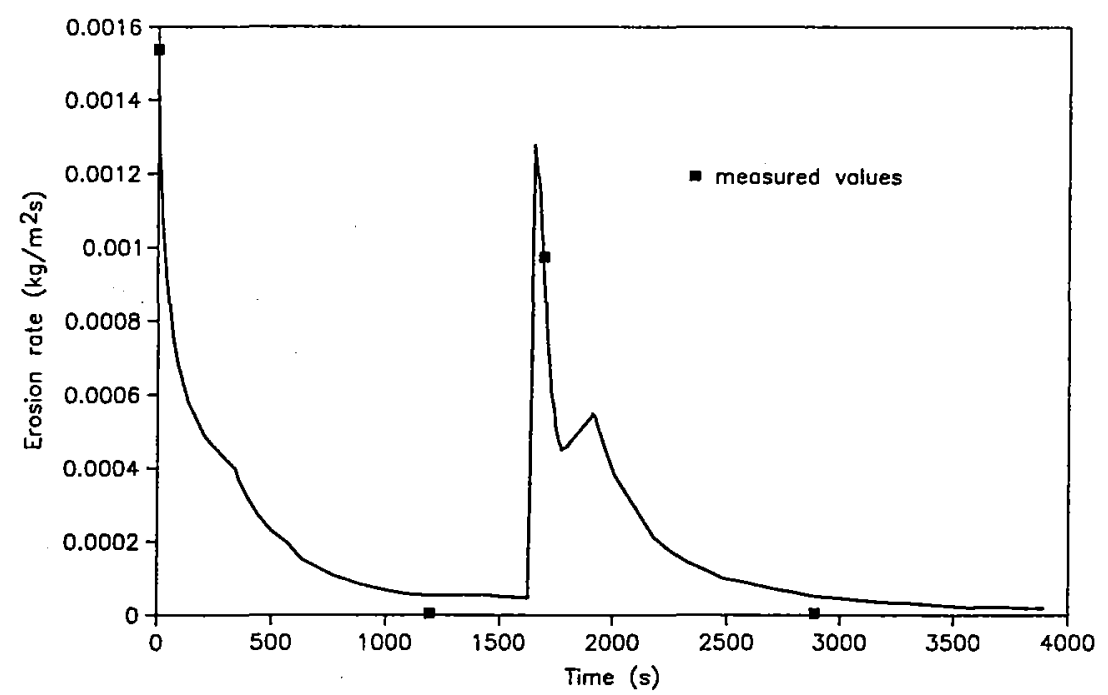

Figure 4.23: Modelling of the mud erosion rates for experiment $\mathrm{J} 6$.

The coefficients a and $E_{f}$ for the erosion formula (equation (2.43)) are of the order of magnitude as the values reported in literature (Table 4.3). The $\zeta$-coefficient for the calculation of the shear strength profile (equation (2.33)) is much higher than expected, normally $\zeta$ is taken around 1 (Mehta, 1988). A higher $\zeta$-value means higher shear strengths for the same density. This is the effect of the passage of the sand through the surface layer. The structure of that layer is much stronger than expected at that density.

In $\S 4.3 .4$ the coefficients a and $E_{f}$ were determined for homogeneous, dense mud2 mixtures: $\mathrm{a}=3.419$ and $\mathrm{E}_{\mathrm{f}}=0.00028$. Compared to the values for experiments $\mathrm{J} 2, \mathrm{~J} 3$ and $\mathrm{J} 5$ (Table 4.7), the coefficient $a$ is higher for the stratified case, but of the same order of magnitude. The floc erosion rates of the layered beds are several orders of magnitude smaller than the floc erosion rates obtained for the homogeneous beds. This indicates that the eroded entities, the flocs, are 
much smaller. This is expected since the top layer consists of soft, pure mud in stead of a dense mud/sand mixture and only suspended load transport is observed.

From Table 4.7 no clear relation between the obtained coefficients and the sand content of each mixture can be found. However, a clear distinction can be made between mud 2 and mud3. For the mud 2 mixtures the average coefficients are:

$\mathrm{a}=15.2 \mathrm{~m} / \mathrm{N}^{1 / 2}, \mathrm{E}_{\mathrm{f}}=3.210^{-8} \mathrm{~kg} / \mathrm{m}^{2} \mathrm{~s}$ and $\zeta=32.6$

For mud3 the following averages can be calculated:

$\mathrm{a}=17.1 \mathrm{~m} / \mathrm{N}^{1 / 2}, \mathrm{E}_{\mathrm{f}}=69.010^{-8} \mathrm{~kg} / \mathrm{m}^{2} \mathrm{~s}$ and $\zeta=12.0$

The a-value is similar in both cases but the floc erosion rates for the mud 2 mixtures are much smaller than for the mud3 mixtures. This means much smaller erosion rates as well as smaller particles being eroded. At the same time the $\zeta$-values indicate a higher erosion resistance for the mud 2 mixtures. For a surface density around $1020 \mathrm{~kg} / \mathrm{m}^{3}$, a critical shear stress of $0.65 \mathrm{~Pa}$ is found for mud2 and $0.24 \mathrm{~Pa}$ for mud3. Whether these differences are due to the difference in sand content or due to the mud type is not clear. Probably it is a combination of both effects.

In fact the influence of the sand content on the erosion resistance and erosion rates depends on the influence of the sand content on the bed formation, because a combination of bed structure, mixture composition and density determines the erosion resistance and the amounts of sediment being eroded.

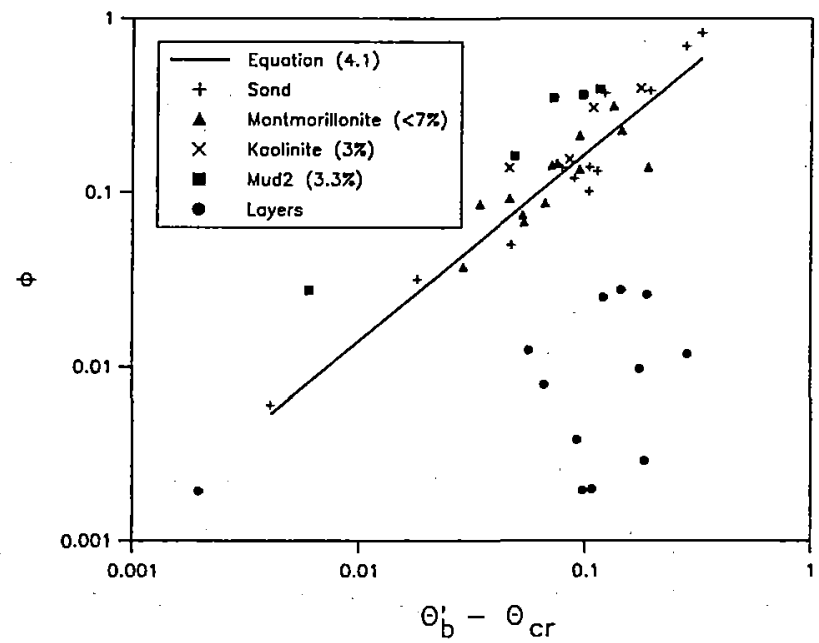

Figure 4.24: Measured bed load transport in the layered bed experiments, compared with equation (4.1). 
In Figure 4.24 the measured bed load transport is compared to predictions using equation (4.1), developed for the used sand. The critical mobility number $(0.09)$ derived from the preliminary sand experiments is used. The measured bed load transport is significantly smaller than the calculated values. There is only a thin layer of sand (few millimetres) in between two mud layers, hence the sand available for transport is limited. Moreover, the sand transport starts from upstream, while downstream the sand is still covered by some mud. Later on, upstream the sand layer is completely eroded while downstream the erosion process still continues. The sand transport is governed by the limited amount of sand that is available rather than by flow conditions.

When comparing all erosion experiments, bed load transport (and hence sand transport) is more important for the experiments with mud 3 than for the mud2 mixtures, they differ almost by an order of magnitude. For the mud2 mixtures, the bed load transport rates are much smaller than the suspended load transport rates. For the mud3 mixtures, both are about same. The mud3 mixtures contain more sand. Moreover, the layer thickness of the mud3 sediment beds is smaller and hence the sand layer is reached earlier.

The measured erosion rates for the muddy phase (suspended load) are similar in all experiments. This indicates that the influence of the sand on the mode of erosion is basically that apart from suspended load an important bed load transport takes place. For high sand contents the erosion rates can be of the same order of magnitude. Hence, the actual erosion is double the value predicted by only considering suspended load. This bed load transport is usually not included in known transport models for cohesive sediment beds. To represent the whole process a sand transport module needs to be included.

\subsection{Summary}

The aim of the experimental work was to study the erosional behaviour of mud/sand mixtures in uniform flow. Therefore, two different kinds of erosion tests were performed. In the previous paragraphs an overview of all the results is given. These results include the erosion resistance of the bed, the mode of erosion of each type of sediment mixture and the relation between measured 
erosion rates and applied shear stress. During the discussion of the experimental data, the stress has been on the influence of the sand content or the amount of fines on the erosion process. But the experiments also demonstrate the important impact of some other parameters such as type of cohesive sediment, bulk density, consolidation time and sediment bed formation. This paragraph summarizes all the information from the experimental study related to each of the above mentioned influencing parameters.

\subsubsection{Influence of mixture composition}

The mixture composition varies with the type and the amount of cohesive sediment used. The amount of cohesive material is expressed as the \%fines, i.e., the percentage by weight of material smaller than $63 \mu \mathrm{m}$. The fraction larger than $63 \mu \mathrm{m}$ is called the sand content; \%fines equals $100 \%$ minus \%sand. As cohesive sediments two types of clay have been used: montmorillonite and kaolinite as well as several types of mud dredged from the Scheldt river in Antwerp.

\section{A. Amount of cohesive material in the mixture}

The amount of cohesive material in a homogeneous mixture has an impact on both the erosion resistance and the mode of erosion of the sediment mixture. Increasing the amount of cohesive material in the mixture, increases the critical shear stress for erosion of the bed (see Figures 4.6, 4.7, 4.8). A small percentage of cohesive material can already enhance the resistance to erosion of the sediment bed significantly. The erosion resistance of a mixture is generally higher than the erosion resistance of pure sand, except at very low \%fines. In that case, no bonds exist between the different particles in the mixture. The erosion starts by washing out the fines from the top layer at bed shear stresses lower than the critical shear stress for sand only. With increasing amount of fines in the mixture the pores in between the sand particles get filled up. The sediment bed becomes hydraulically smoother and less permeable. This means that the grain Reynolds number Re. reduces and according to the left hand side of the Shields diagram (Figure 2.2, $\left.\mathrm{Re}_{*}<5\right)$ the critical shear stress increases. At still higher amounts of cohesive sediment, the 
mixture becomes cohesive. Cohesive bonds between the particles enhance the erosion resistance even more.

Furthermore, the mode of erosion changes with the amount of fines in the sediment bed. At low amounts of cohesive sediment in the mixture the erosion processes are similar to sand erosion: ripples and dunes develop and these bed forms move as bed load. When the mixture contains a high amount of cohesive sediment the erosion of the bed resembles the erosion of cohesive sediments: mass erosion or surface erosion. In some cases, e.g., for the montmorillonite mixtures, this change in mode of erosion passes through a clear transition zone. For other mixtures there is a rather abrupt change.

For the deposited mixtures the amount of cohesive material, in this case expressed as the sand content, influences the structure of the formed bed and has an impact on erosion resistance and mode of erosion. In fact the influence of the sand content on the erosional behaviour is a consequence of the influence the sand content has on the bed formation process.

A bed formed after deposition of consecutive inputs of a mud/sand slurry shows a layered structure. Due to the amount of sand in the mixture, segregation occurs and a high density sand layer is formed. This sand layer enhances drainage of the water being expelled from the muddy layer during consolidation and this speeds up the consolidation of the bed. Increasing the sand content results in a decreasing layer thickness and increasing bed densities. However, a maximum sand content exists above which no additional effect of an increasing sand content is noticed.

These bed formation processes, caused by the deposition of a low density mud/sand mixture, have several impacts on the erosion of the bed. Increased bed density, due to the sand content, increases the erosion resistance of the bed. Even the sand-free surface layer (a result of segregation) is less erodible due to the presence and the passage of the sand. The erosion process itself is a consecution of suspended load (muddy layer) and bed load (sand layer) erosion phases (Figure 4.22). Depending on the sand content, the bed load transport can be as important as the transport of sediment in suspension. Hence, to model the complete erosion and sediment transport process, a sand transport formula has to be implemented as well. 


\section{B. Type of cohesive material}

The importance of the type of cohesive sediment used is clearly demonstrated by the results of the homogeneous bed experiments. The measured critical shear stress for erosion, for mixtures containing the same amount of cohesive sediment, varies significantly between the different types of cohesive material. The kaolinite and the mud mixtures have critical shear stresses that are more or less twice the values measured for montmorillonite mixtures (Figures 4.6, 4.7, 4.8) at a similar \%fines.

The transition from cohesionless to cohesive behaviour also depends on the type of cohesive material. For kaolinite and mud mixtures a small amount of fines added to sand already makes the mixture very cohesive. For the montmorillonite mixtures this transition is more gradual.

Further, the mode of erosion differs, depending on the type of cohesive material. For some kaolinite and the mud mixtures, especially at low density, the erosion can be described as surface erosion. Individual grains or flocs erode. The fines go into suspension and the sand fraction is mainly transported as bed load. From most of the high density mixtures, whole crumbs of material are being removed and transported as bed load, which is a mass erosion phenomenon. The same holds true for the erosion of low density montmorillonite mixtures.

The erosional behaviour of the homogeneous mud mixtures is quite comparable to the behaviour of kaolinite mixtures. The measured erosion resistance is more or less the same for similar mixtures. The mode of erosion and the observed erosion patterns of the kaolinite mixtures resemble the erosion process of the mud mixtures. Many other researchers also used kaolinite in their experiments (Einsele et al. 1974, Kusuda et al. 1982, Mehta et al. 1975, among others). It seems to be an easy to handle but reliable substitute for natural cohesive sediments, although of course many aspects of natural sediments e.g., related to the organic content, are omitted.

The montmorillonite mixtures show a very specific behaviour, less comparable to the behaviour of the Scheldt mud mixtures. However, the observed mass erosion processes have also been mentioned in literature describing field surveys (Amos et al. 1994).

In the experiments on deposited beds two types of Scheldt mud are used. These two types of mud have both been dredged in the harbour of Antwerp. Therefore, similar characteristics can be 
expected. The most significant difference between the two samples is their natural sand content: for mud2 around $15 \%$, for mud3 $38 \%$. The differences in the bed formation process (segregation, layer thickness, density) are mainly due to the different sand content. But also the type of mud has some effect. The mineralogical composition and organic content of the mud determine the structure formed in the bed. This structure in turn has an effect on the behaviour of the sand during settling and consolidation and hence on the erosion resistance of the deposited bed. The erosion of both types of beds is very similar, the only differences again can be attributed to the sand content.

\subsubsection{Influence of bed density and consolidation time}

The bed density has an impact on both the erosion resistance and the mode of erosion and sediment transport of the homogeneous mixtures. Higher bed densities will increase the erosion resistance of the bed significantly. When the density decreases the bonds between the different particles in the bed get weaker. In Figure 4.7 the measured critical shear stresses for kaolinite mixtures are compared. The erosion resistance of the low density mixtures is significantly lower than for a similar high density mixture. The scatter of the data indicates that the critical shear stress is very sensitive to small changes in bed density. Another consequence of the weaker bonds is that the importance of suspended load increases. The eroded entities disintegrate and only the coarser sand grains are transported as bed load.

For the montmorillonite mixtures, Figure 4.6 , the situation is less clear. No significant differences in erosion resistance between the $1.8 \mathrm{~kg} / \mathrm{dm}^{3}$ and the $1.65 \mathrm{~kg} / \mathrm{dm}^{3}$ are found. The erosion of the low density mixtures is still mass erosion, similar to the high density mixtures. For the kaolinite beds, the erosion of the low density mixtures is better described as surface erosion.

The consolidation time has a similar effect on the erosion of the homogeneous mixtures. When the consolidation time increases, the mixtures become denser and have had more time to regain strength after the mixing process. This leads to higher erosion resistance and more bed load transport. 
The average density of the deposited beds is much smaller than the homogeneous beds $\left(1.1 \mathrm{~kg} / \mathrm{dm}^{3}\right.$ versus 1.6 to $\left.1.9 \mathrm{~kg} / \mathrm{dm}^{3}\right)$ and therefore the calculated erosion resistances for these mixtures are an order of magnitude smaller than for the homogeneous mixtures. The erosion process is surface erosion with much smaller floc erosion rates than calculated for the homogeneous, denser beds.

\subsubsection{Influence of bed formation}

When a sediment bed is formed by deposition of a suspension, the bed shows significant density gradients. This has an important influence on the erosion process. When a homogeneous mixture is eroded, the erosion rates are constant in time. In Figure 4.25 the erosion of a homogeneous mud2 mixture is presented. The cumulated bed load increases linearly in time. However, when the bed is stratified and its density increases with depth, the erosion rates are decreasing in time. Together with the density, the erosion resistance of the bed increases with depth and the excess shear stress, proportional to the erosion rate, decreases. Figure 4.26 represents the erosion of a layered mud2 mixture. The slope of the cumulated bed load decreases in time.

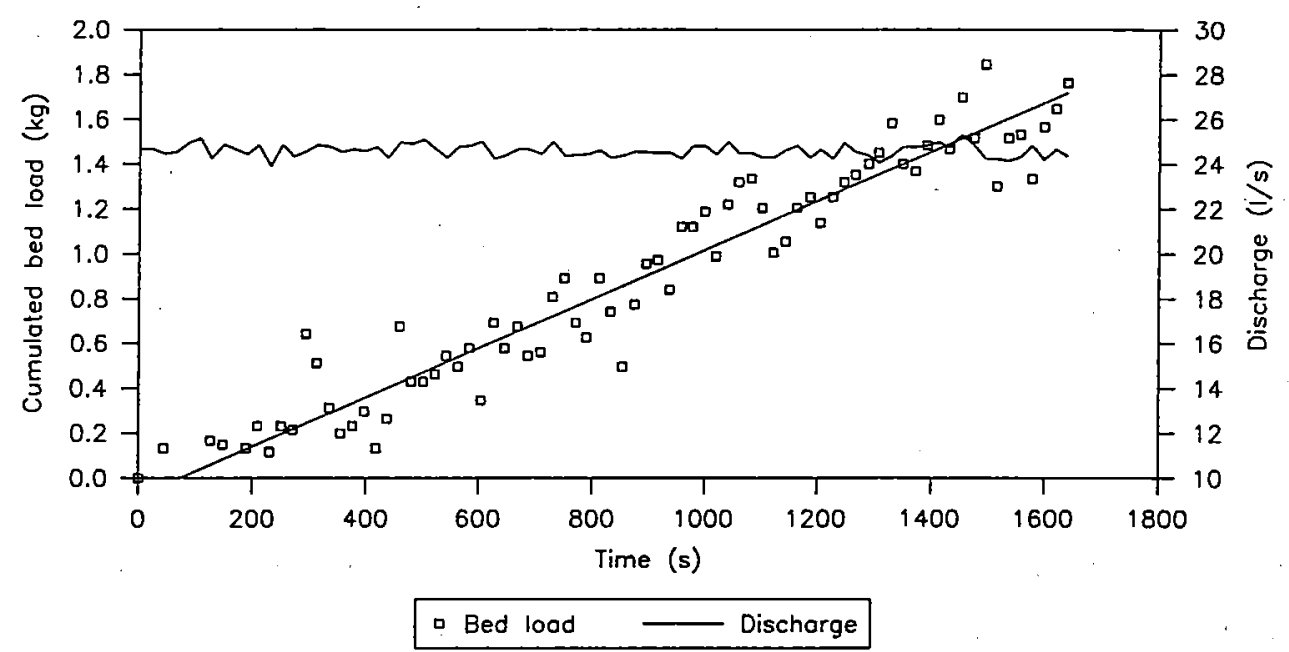

Figure 4.25: Erosion of a homogeneous mud2 mixture. 
When the suspension is a mixture of mud and sand, segregation can occur and a sand layer is formed. These processes lead to another form of stratification: a sequence of mud and sand layers. The erosion of this bed is also a sequential process. The muddy layer on top will be eroded and transported in suspension, but when the sand layer is reached, bed load transport occurs.

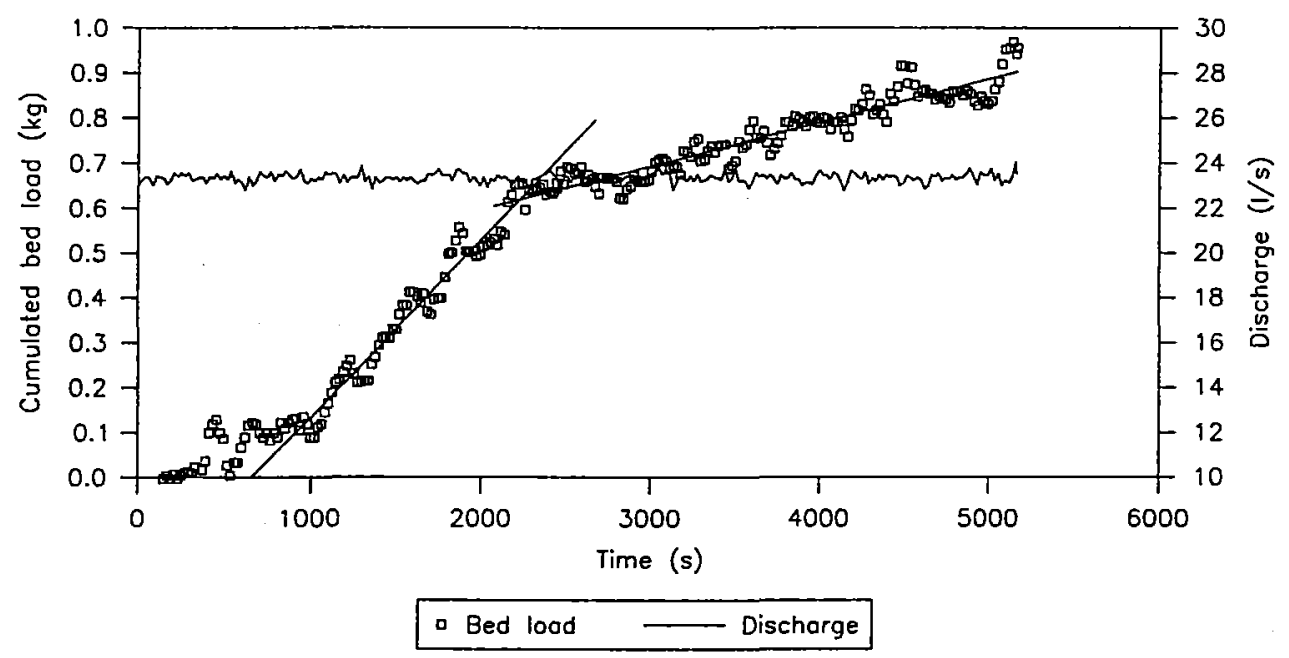

Figure 4.26: Erosion of a layered mud2 mixture. 


\section{Chapter 5: The influence of the shape}

\section{and scale of the flume cross section on}

\section{bed shear stress calculations}

\subsection{Introduction}

The bed shear stress is an important parameter in sediment transport studies. The maximum value of the bed shear stress determines whether or not erosion will occur, the average bed shear stress is related to the amount of sediment being transported by the flow and the bed shear stress distribution gives an indication of the erosion patterns that will develop during the erosion process. Hence, an accurate calculation of the bed shear stress is important. The accuracy of the different methods used for the calculation of bed shear stresses has been discussed in $\S 3.7$. But in order to apply the experimental results of this study to field situations, large estuaries or circular sewer pipes, the effects of the shape and the scale of the laboratory flume on the bed shear stress calculations need to be investigated. Indeed, the experimental knowledge on the erosion of mud/sand mixtures is based on experiments in a small laboratory flume. As mentioned before ( $\$ 3.7 .3$ ) the bed shear stress distribution in a small flume is influenced by the side walls. Moreover, most sediment transport theories have been developed using experimental data for laboratory flumes and rivers and not for e.g., circular cross sections.

Preliminary experiments $(\$ 3.3 .2)$ already demonstrated that the measured velocity profiles differed according to the position in the cross section, where they were measured. The side walls of the flume have a roughness that differs from the roughness of the sediment bed. They influence the velocity distributions and, hence, the bed shear stress distributions in the cross section, significantly. It is clear that this influence will be more pronounced for narrow flumes, therefore the impact of the aspect ratio (width over depth ratio) needs to be checked.

On the other hand the shape of the cross section also affects bed shear stress distributions over the flume cross section. In the conclusions of the First International Workshop on the Origin, Occurrence and Behaviour of Sewer Sediments some specific aspects are cited, that need to be 
considered when attempting to model sediment transport and that differ significantly from typical river conditions (Verbanck et al. 1994). One of these aspects is that conduit shape effects are more important in the much narrower sections of sewers than for river hydraulic conditions. In the framework of an interuniversity F.K.F.O.-research project on the erosion of partly cohesive sediments, comparable experiments were carried out in the Hydraulics Laboratory of the Universiteit Gent. The flume in Gent has a similar concept and comparable dimensions but its cross section is semi-circular with a diameter of $40 \mathrm{~cm}$. For a sediment bed of $4 \mathrm{~cm}$ in the middle of the cross section, the sediment width is reduced to $23.7 \mathrm{~cm}$.

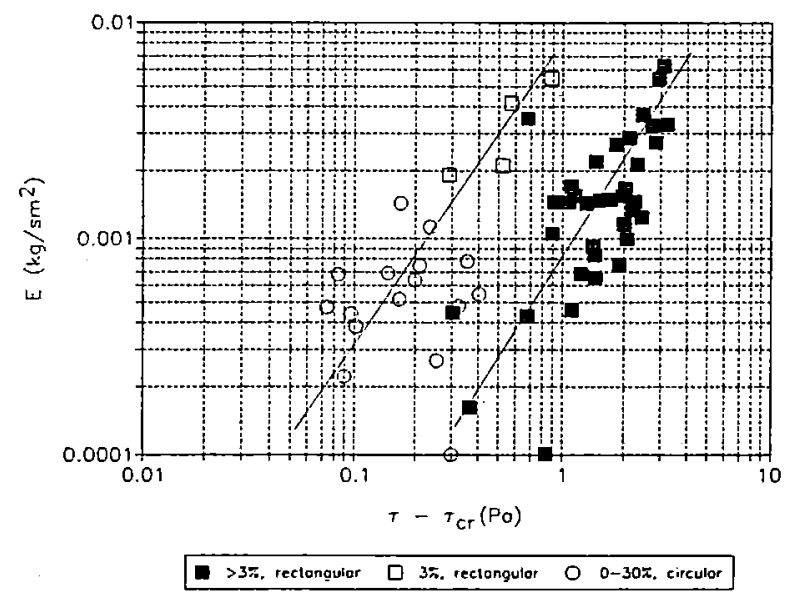

Figure 5.1: Comparison of measured erosion rates for kaolinite mixtures.

A comparison of results of similar experiments in both flumes demonstrates important shape effects in the measured erosion rates and observed bed form development. For a similar sediment bed, i.e., a well-defined mixture of cohesive and cohesionless sediments, the erosion rates in the circular flume are an order of magnitude higher under identical flow conditions. In Figure 5.1 the erosion rates for homogeneous kaolinite mixtures are compared for both cross sections. At the same excess shear stress, much more erosion takes place in the semi-circular flume. Along the walls of the circular flume highly irregular bed forms develop and deep holes appear locally, whereas the bed forms and erosion patterns usually are quite uniform in the rectangular flume. The measured critical shear stresses for similar sediment mixtures, however, do not differ significantly (Torfs et al. 1994). 
The encountered differences and similarities are induced by the secondary flow structure and the cross sectional bed shear stress distribution. Both are strongly dependent on the narrowness and the shape of the cross section. These particular shape effects are the subject of more detailed additional experiments, performed in Leuven (rectangular cross section) as well as in Gent (semi-circular cross section). In these tests accurate measurements of the velocity distribution over both cross sections are carried out, in order to compare the different shear stress calculation methods and to identify the shape and scale effects. In the framework of the interuniversity project velocity profiles have also been measured in the major collector sewer of Brussels and in the river Scheldt at Temse. These field data can provide even more information on shape and scale effects.

\subsection{Literature review on the relation between secondary currents and shear stress distributions}

The flow in longitudinal direction along the flume is called the primary flow. Transverse circulations in the cross section are secondary currents. These secondary currents are generated and modified as a result of the anisotropy of the turbulence. This anisotropy, in turn, is caused by the boundary conditions of the bed, the side wall and the free surface as well as the aspect ratio of the channel and the channel geometry. Research by Nezu et al. (1985) showed that when the aspect ratio becomes smaller than 5 , the flow becomes strongly three-dimensional. Accurate measurements of the secondary currents are very difficult to achieve since their maximum value is about 1.5 to $2 \%$ of the corresponding longitudinal velocity (Tominaga et al. 1989). Therefore, not much research has been reported on the influence of the shape of the cross section on secondary currents and shear stress distributions. However, the secondary currents affect the mean flow and have an impact on the sediment transport processes.

Tominaga et al. (1989) describe a laboratory study in which detailed measurements of the secondary flow structure were made for rectangular and trapezoidal flumes of compound roughness. In case of a rectangular flume two vortices exist near the side wall: the bottom vortex (A, Figure 5.2) and the free-surface vortex (B, Figure 5.2), which are separated at about $0.6 \mathrm{H}$ ( $H$ represents the total water depth). The free-surface vortex is responsible for the deceleration 
of the longitudinal velocity near the water surface, the so called velocity dip phenomenon, and it restrains the development of the bottom vortex (Nezu et al. 1985). For a wide channel (large aspect ratio) the span-wise scale of the free-surface vortex can go up to two times the water depth. The scale of the bottom vortex is always smaller than the water depth in open channel flow. The span-wise length scales of both the vortices increases as the roughness of the side walls increases relatively to the bottom roughness. Another possibility is that the bottom vortex in case of a rough bed breaks up into different smaller vortices. These phenomena clearly demonstrate the importance of the aspect ratio (bed width over water depth) and the roughness of the flume. In other words, narrow flumes will behave differently than e.g., wide rivers.
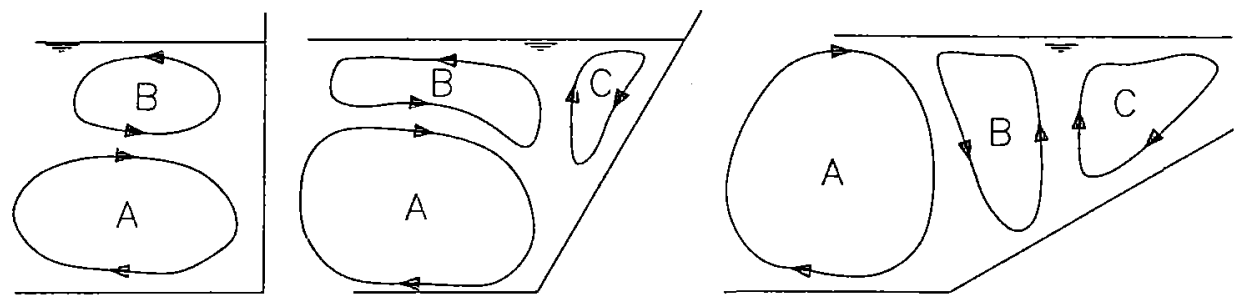

Figure 5.2: Secondary flow structure in different cross section (Tominaga et al. 1989).

In case of a trapezoidal channel an extra vortex is created (C, Figure 5.2) between the side wall and the free surface. The free-surface vortex becomes less dominant, and, with increasing side wall angle, the bottom vortex extends until the free surface. This means that the decelerating effect of the free-surface vortex decreases as well. A strong secondary flow towards the corner results. It can be noted that a semi-circular cross section with a sediment bed resembles a trapezoidal cross section well.

The secondary flow structure has an effect on the distributions of longitudinal velocities and bed shear stresses in the cross section. For rectangular and trapezoidal cross sections Tominaga et al. (1989) as well as Sarma (1993) have demonstrated a good agreement between local maxima in the bed shear stress distribution and the flow in the secondary flow cells pointing towards the bed and vice versa, local shear minima corresponding to secondary currents away from the bed. The location of the maximum bed shear stress depends on the number of secondary flow cells and on their intensity (Sarma 1993). When more flow cells occur, e.g., for a rough bed, the shear stress distributions will be very undulated. In a semi-circular flume with sediment bed (similar to a 
trapezoidal cross section) the local maximum near the side wall becomes more important as a result of the extra flow cell. Even the absolute maximum bed shear stress can be situated out of the centre of the cross section.

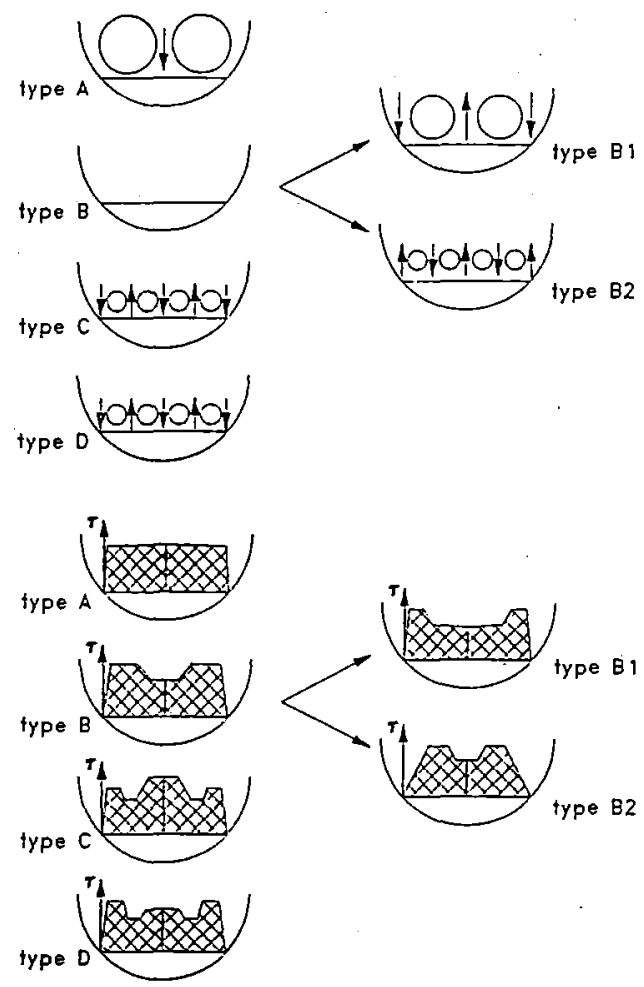

Figure 5.3: Classification of possible bed shear stress distributions in a circular cross section (Kleijwegt 1992).

Kleijwegt (1992) has done a number of experiments in a flume with circular cross section with a sediment bed. He made a classification of possible secondary flow structures and the corresponding bed shear stress distributions depending on the water level and the sediment width (Figure 5.3). He concluded that the narrowness of the flume has a strong impact on the average bed shear stress whereas the shape influences the distribution of the bed shear stress over the cross section. He presented the hypothesis that for a narrow flume and due to the differences in roughness between wall en bed, one of the assumptions for the side wall elimination technique $U_{\text {wall }}=U_{\text {bed }}$ (see Appendix 1) no longer holds true. When the flume walls are smooth, the flow velocity in the wall section is higher than, or at least equal to, the velocity in the bed section. In 
his opinion the bed shear stress calculated by the side wall elimination technique is the maximum bed shear stress and hence an overestimation of the average bed shear stress. According to Kleijwegt the difference between the average bed shear stress and the bed shear stress calculated by side wall elimination diminishes when bed forms appear on the bed.

Alvarez (1990) studied the influence of cohesion on the erosion of a sediment bed in a circular pipe. From detailed velocity measurements in the pipe at different water depths he concluded that only for intermediate water depths the three-dimensional flow structure becomes important. He found a good agreement between the average bed shear stress and the bed shear stress from a side wall elimination calculation.

\subsection{Experiments}

\subsubsection{Rectangular cross section}

To study secondary currents and shear stress distributions in our flume, detailed measurements of the velocity distribution over the cross section are made, during some additional experiments. Velocity profiles are measured along 6 or 7 verticals evenly distributed over half the cross section. Near the bed a velocity reading is taken every $3 \mathrm{~mm}$, further from the bed the vertical interval is gradually increased.

From the bottom part of these velocity profiles, the bed shear stress in different points along the width of the cross section can be calculated, assuming that the logarithmic profile is valid over $15 \%$ of the water depth (Sarma 1993). Using the side wall elimination technique a global (average?) bed shear stress is obtained. Both calculation methods have been explained in $\S$ 3.7.3. Using a computer programme (UNIMAP), the velocity data are interpolated and transformed into isovels (lines of equal velocity).

Figure 5.4 gives the measured velocity profiles for an experiment with a kaolinite mixture. The sediment bed was smooth, no bed forms or erosion patterns existed. The measured profiles all seem to follow the logarithmic law very well, even up to more than $15 \%$ of the water depth. The influence of the walls of the narrow flume is responsible for the decreasing velocities towards the sides. The influence of the narrowness of the flume and of the side walls is less when the bed 
roughness is large compared to the wall roughness. In Figure 5.5 the velocity profiles for an experiment with a sand bed are plotted. The roughness of the sand bed is much higher than for the mixture bed, hence, the relative influence of the (smooth) side walls is less important. Close to the wall the velocity decreases rapidly (Figure 5.5), but near the centre $(0-10 \mathrm{~cm}$ ) the measured velocity profiles are almost the same.

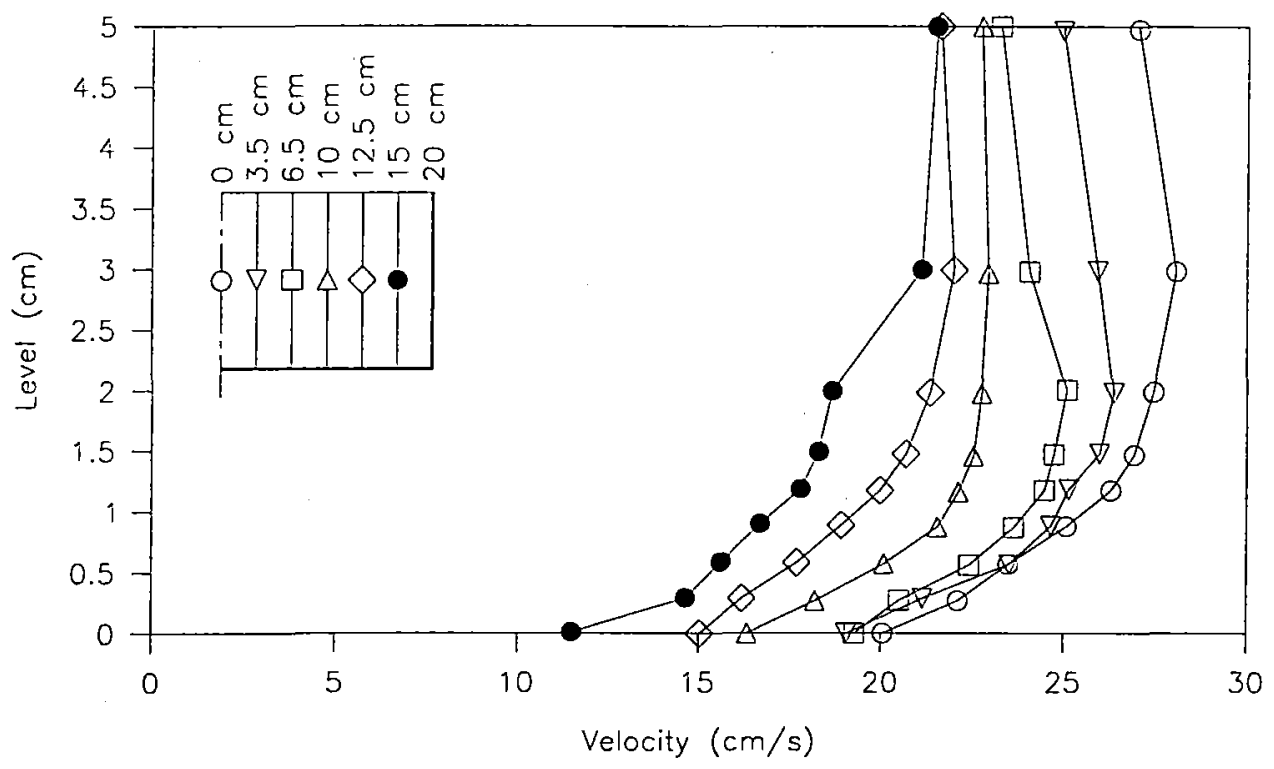

Figure 5.4: Measured velocity profiles for an experiment with a smooth sand/kaolinite bed. The legend gives the distance from the centre in centimetres.

The decreasing velocities towards the surface (Figure 5.4) and the velocity dip, indicate the presence of the free-surface vortex. Above the rough bed, in Figure 5.5, the central profiles $(0$ and $3.5 \mathrm{~cm}$ ) don't seem to be influenced by the decelerating effect of the free-surface vortex. The other profiles do show a decrease in velocities towards the surface. The importance and scale of the free-surface vortex depends not only on the aspect ratio but also on the relative roughness of the bed. For a smooth bed (Figure 5.4) the decelerating effect extends to a bigger part of the cross section. 


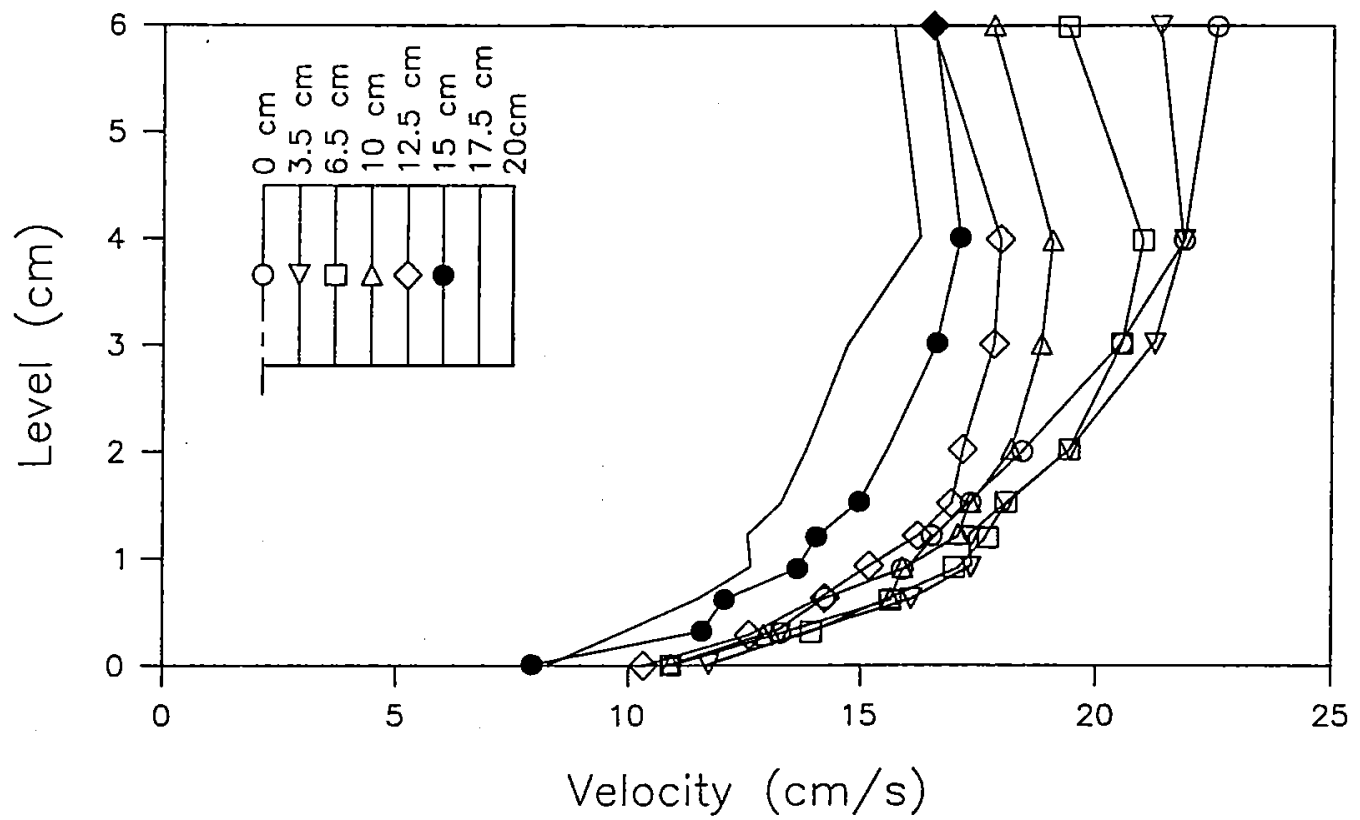

Figure 5.5: Measured velocity profiles for experiment on a rougher sand bed. The legend gives the distance from the centre in centimetres.

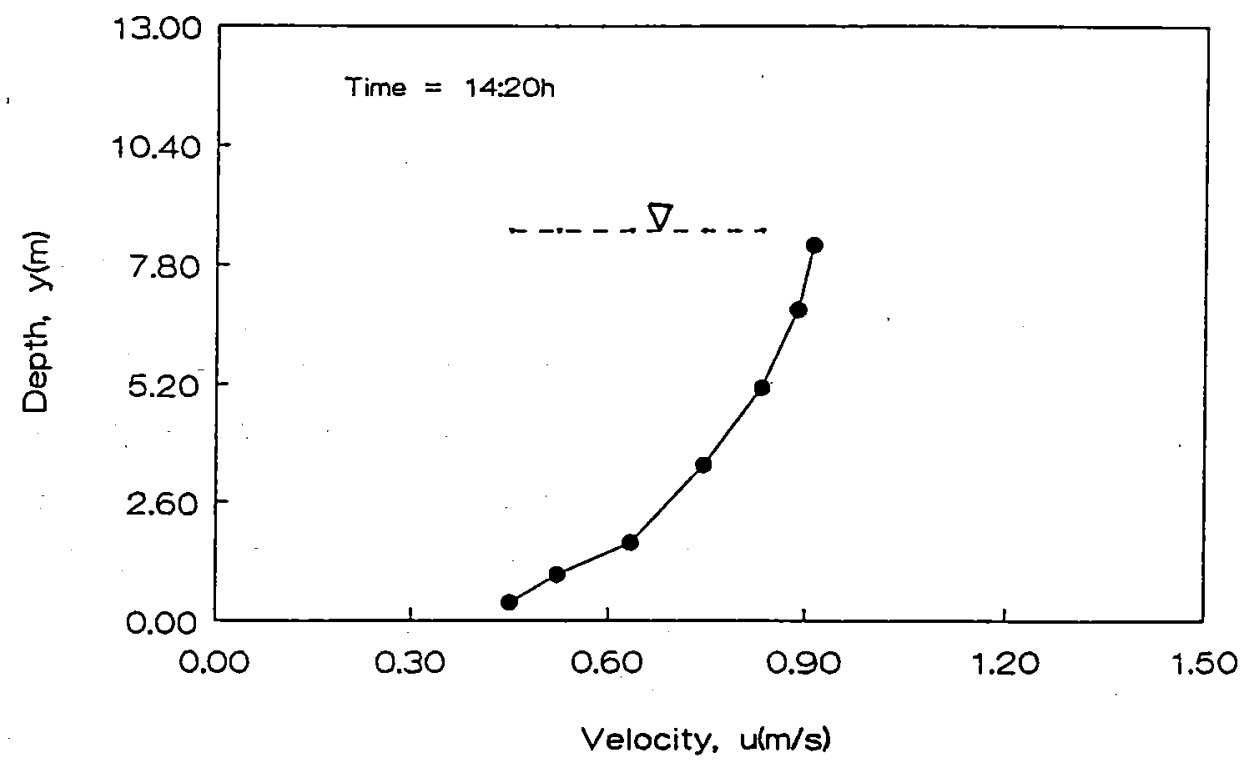

Figure 5.6: Example of a velocity profile, registered during a sediment transport measuringcampaign on the river Scheldt at Temse (Kabir et al. 1991). 
In Figure 5.6 an example is given of one of the velocity profiles taken during the measuringcampaign on the river Scheldt at Temse. This profile was measured about two hours after low tide. At Temse the Scheldt has a total width around $300 \mathrm{~m}$ which means that in this case no side wall influence is expected. Indeed, none of the measured velocity profiles showed decreasing velocities towards the free surface (Kabir et al. 1989). This example demonstrates the importance of scale effects: experimental results from a small laboratory flume cannot be extrapolated as such to wide rivers.

The isovels for the experiment on the smooth sand/kaolinite bed are plotted in Figure 5.7. The secondary currents are very difficult to measure: these velocities are only a few percent of the longitudinal velocity, which is about the possible accuracy of the used pitot tube and differential pressure transducer (see Appendix 2). Therefore, the secondary flow structure is deduced from the isovel plot (Sarma 1993). Secondary currents are said to be perpendicular to the isovels at the points of highest velocity gradients and highest angular deviation of the isovels. The number of secondary flow cells is determined by the aspect ratio. Tominaga et al. (1989) found that the span-wise scale of these cells is of the order of magnitude of the water depth. In this case the water depth was $5.8 \mathrm{~cm}$, thus maximum three to four flow cells can occur over half the cross section $(20 \mathrm{~cm})$. This means in theory three local maxima in the shear stress distribution. In Figure 5.7 a possible secondary flow pattern is drawn (by hand).

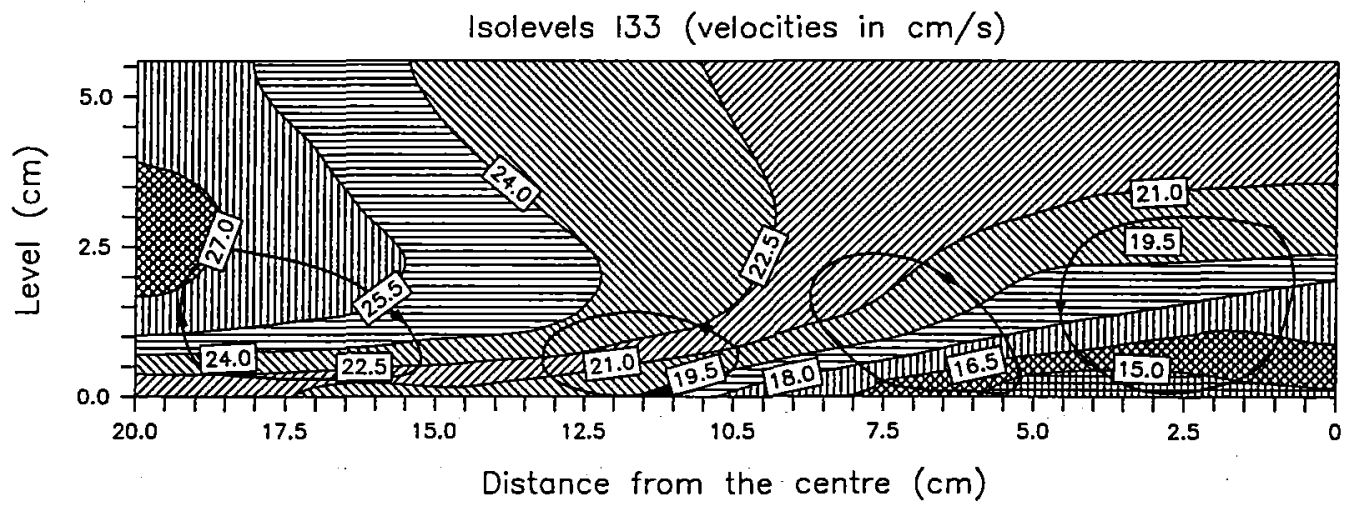

Figure 5.7: Isovels for the kaolinite/sand experiment.

Using the law of the wall the shear stresses are calculated for each vertical. For the experiment of Figure 5.4, the calculated shear stress distribution is plotted in Figure 5.8. The distribution is quite uniform. The small shear stress variations are of the order of magnitude of the possible 
errors made during the calculations (see sensitivity analysis in § 3.7.3 and Appendix 2). In this case the shear stress is maximal around the centre vertical or just outside the centre. The distribution goes to some sort of local minimum of about $0.15 \mathrm{~Pa}$ at $10 \mathrm{~cm}$ and increases again towards the corner. Due to the limited number of verticals, it is possible that the distribution plotted in Figure 5.8 is not showing the complete picture. Some local extremes may fall in between the measuring points. However, most of the measured shear stress distributions showed a similar uniform behaviour. In few cases the maximum near the corner is much more important than the centre value. This explains the observation that in some cases the erosion started along the sides of the flume, although in most experiments the erosion was quite uniform or concentrated around the centre line of the flume as described in $\$$ 4.3.2.

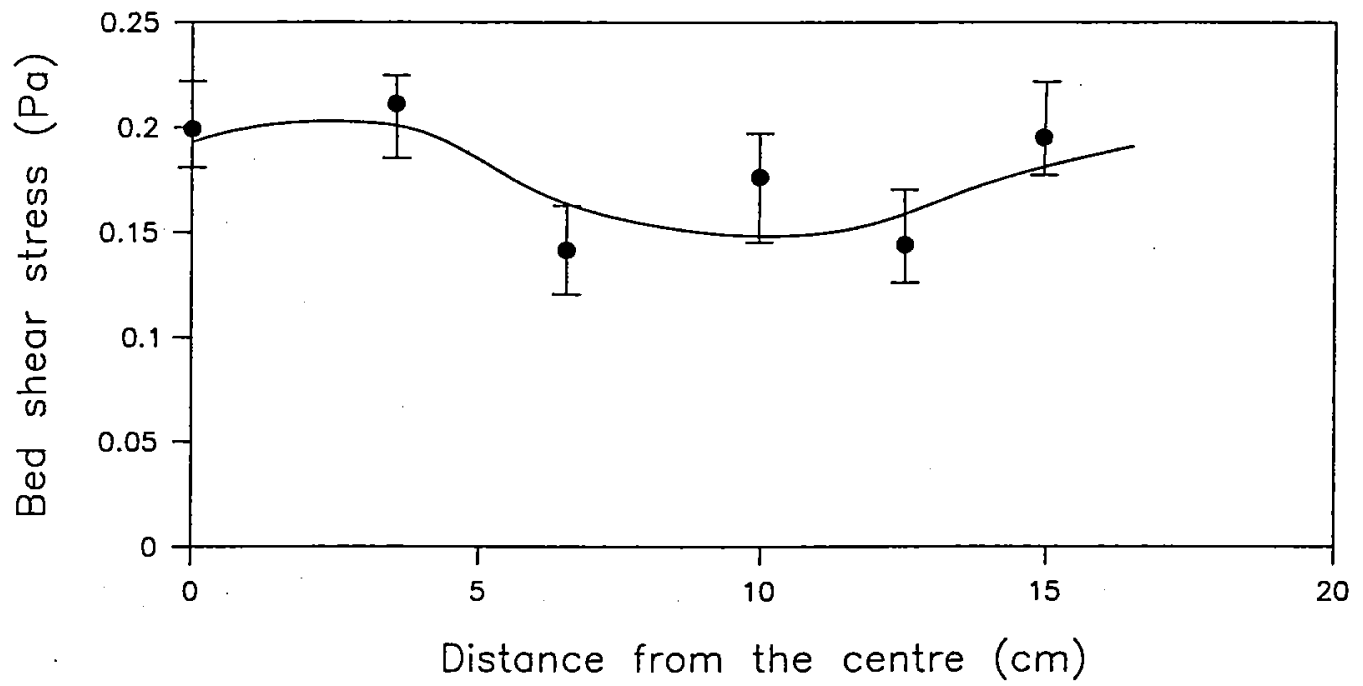

Figure 5.8: Bed shear stresses along the cross section, calculated from the velocity distributions, for the kaolinite mixture experiment.

In Figure 5.9 the maximum bed shear stress is plotted as a function of the centre line shear stress, both calculated from the velocity profiles. Almost all points seem to fall around the line of perfect agreement. One point deviates a lot: in that experiment the maximum bed shear stress was found near the corner of the cross section. The bed shear stress calculated from the centre line velocity profile seems a reliable indicator for the maximum bed shear stress in the cross section. In most of the erosion experiments only this central velocity profile was measured ( $\$ 3.3 .2$ ). However, the accuracy of the shear stress calculation from the velocity profile decreases when 
the erosion starts and the bed level becomes less accurately known. Especially when bed forms are present, these calculations are no longer reliable.
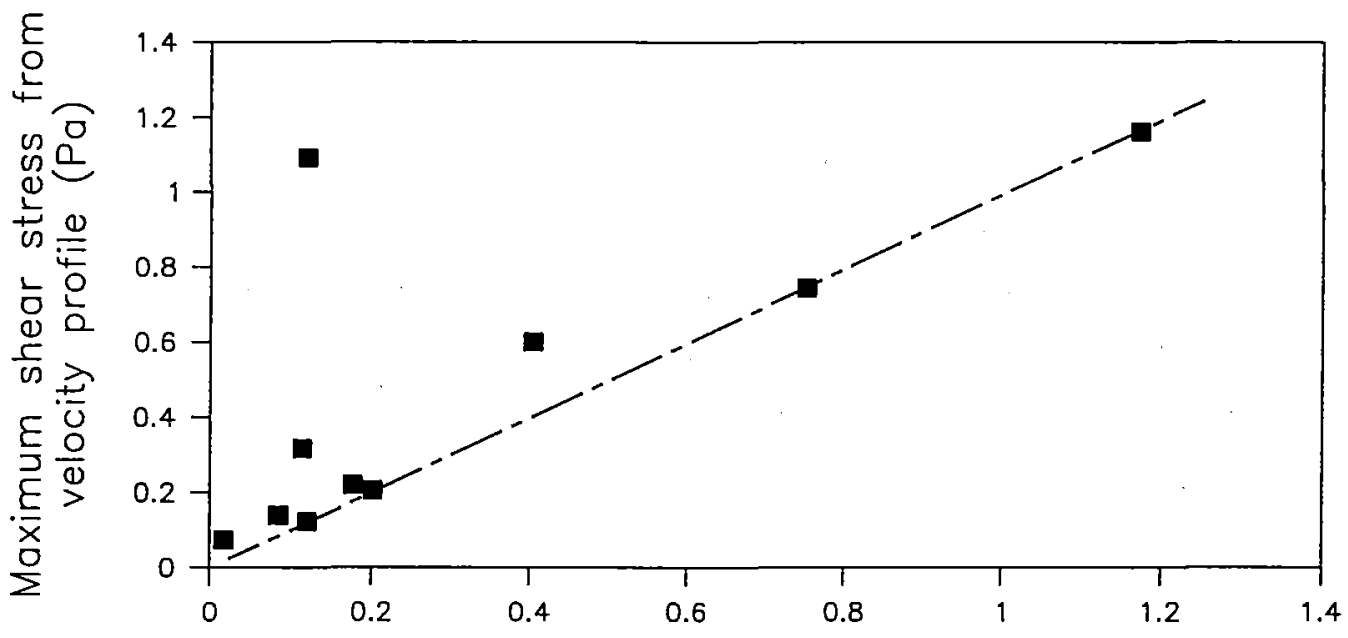

Centre line shear stress from velocity profile ( $\mathrm{Pa}$ )

Figure 5.9: Maximum versus centre line bed shear stress, calculated from the velocity profiles.

5.3.2 Comparison between the side wall correction method and the law of the wall

During the laboratory tests normally no detailed measurements of the velocity distribution over the cross section exist. Mostly only the velocity profile along the centre line is measured or an overall bed shear stress is calculated from the average hydraulic data using a side wall elimination method. Also when in situ measuring campaigns are carried out only a few velocity profiles are registered. But for the prediction of the onset of erosion the maximum bed shear stress is required. The average bed shear stress on the other hand determines sediment transport rates. Therefore the relation between mean bed shear stress and maximum bed shear stress has been checked and the different methods to calculate bed shear stresses are compared.

Kleijwegt (1992) already found that for narrow flumes the side wall elimination method overestimates the average bed shear stress in the cross section. For our experiments, the bed shear stress calculated by side wall elimination $\left(\tau_{\mathrm{swC}}\right.$ ) is fairly equal to the maximum shear stress from the velocity profiles $\left(\tau_{\max }\right.$ ) as is shown in Figure 5.10, most points fall around the line of perfect agreement. This would support the hypothesis by Kleijwegt. The scatter of the data around the 
line of perfect agreement could be due to the sensitivity of the law of the wall calculations to the knowledge of the reference level. When special attention is paid to this problem (i.e., the bottom is smoothed and levelled more accurately, the pitot tube is positioned very carefully), the agreement between $\tau_{\max }$ and $\tau_{\text {swc }}$ becomes a lot better, as indicated by the circular points in Figure 5.10. As mentioned before, when erosion takes place, the accuracy of the calculations diminishes due to the uncertainties about the bed level. Kleijwegt (1992) suggested that in that case the differences between $\tau_{\text {swc }}$ and the average bed shear stress $\tau_{\text {mean }}$ become very small.

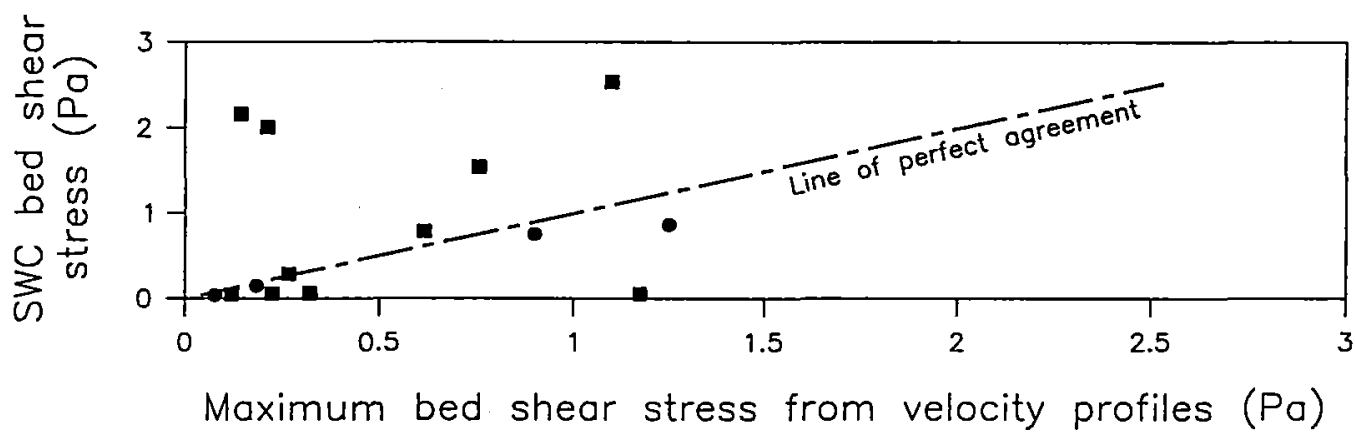

Figure 5.10: Comparison between side wall elimination and the maximum bed shear stress.

Also the relation between maximum and average bed shear stress both calculated from the measured velocity profiles has been checked. For most experiments $\tau_{\max }=1.41 \tau_{\text {mean }}$ (the mean shear stress from the velocity profiles) as shown in Figure 5.11. Since for the rectangular cross section $\tau_{\max } \approx \tau_{\text {centre }}$ the average bed shear stress can be calculated as $71 \%$ of the centre line bed shear stress or even, assuming that Kleijwegt's hypothesis is correct, as $71 \%$ of the bed shear stress calculated by side wall elimination.

No relation was found between $\tau_{\text {swc }}$ and $\tau_{\text {mean }}$, the only conclusion is that the side wall elimination method gives an overestimation of the average bed shear stress. 


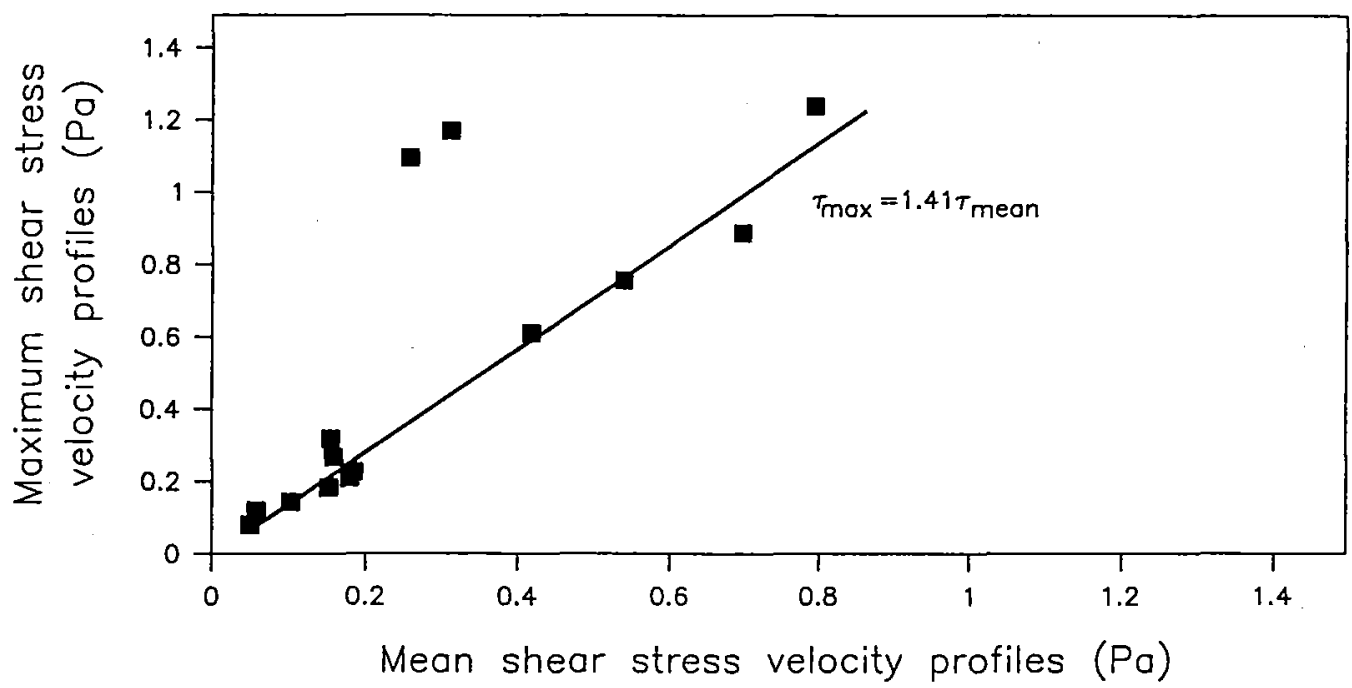

Figure 5.11: Maximum versus mean bed shear stress, both calculated from the measured velocity profiles.

\subsubsection{Comparison with a circular cross section}

A similar set of detailed experiments is performed in the semi-circular flume of Gent in order to study the shape effects. For a (semi-) circular flume the shape of the cross section varies significantly with the degree of filling (water depth). For a small sediment depth, the semicircular cross section is very similar to a trapezoidal cross section.

Figure 5.12 shows the measured velocity distributions over half the cross section of the Gent flume. In Figure 5.12 also two velocity profiles measured above the side walls of the circular cross section are plotted. Those velocities are significantly lower than the velocities measured above the bed. When comparing the measured velocity distributions for both cross sections (Figures 5.4 and 5.12) the influence of the shape of the cross section becomes clear. In both cases the velocities are decreasing towards the side walls. But only in the rectangular cross section decreasing velocities towards the free surface are found. Indeed, for a semi-circular cross section with sediment bed (i.e., almost a trapezoidal cross section) no free-surface vortex is expected (Tominaga et al. 1989, see Figure 5.2) and thus no decelerating effect of this vortex can be 
registered. But near the intersection of the walls with the sediment bed two important secondary flow cells can be found. They are responsible for the much lower velocities measured there and demonstrate the important influence of the cross sectional shape on the secondary flow structure.

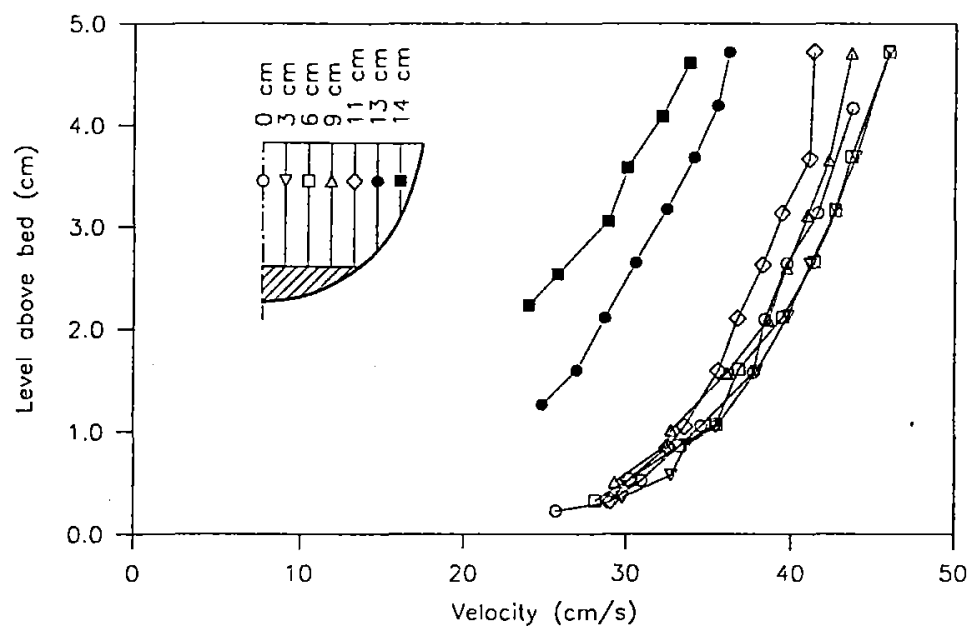

Figure 5.12: Measured velocity distributions for the semi-circular flume.

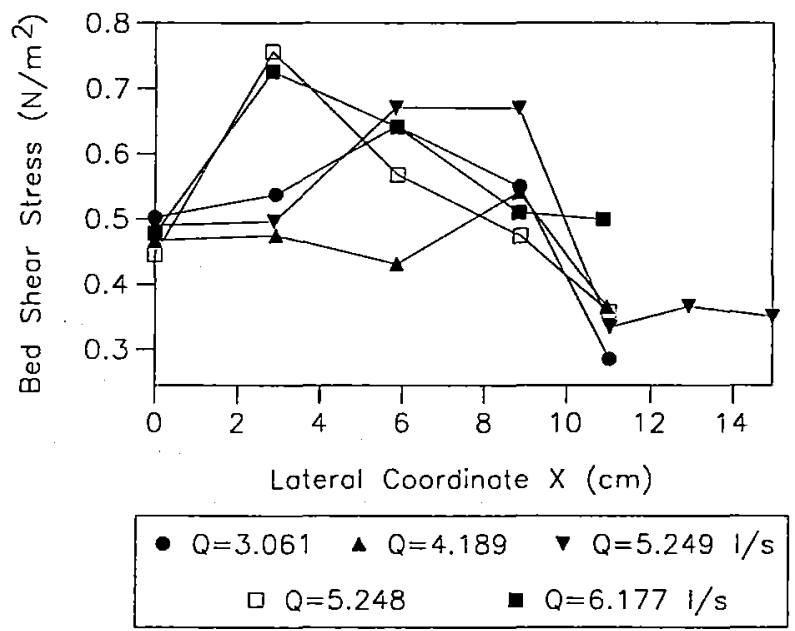

Figure 5.13: Shear stress distributions measured for the semi-circular cross section for different values of the flow rate. In abscissa the distance from the centre is given. 
Figure 5.13 shows some typical examples of the shear stress distributions as calculated from the velocity distributions for the semi-circular cross section. For the rectangular cross section (Figure 5.8), always a nearly uniform shear stress distribution over the flume width is noticed with in most cases only one clear maximum in the centre. The shear stress distributions over the circular cross section (Figure 5.13) are highly non uniform and vary with flow depth and flow rate. Depending on the flow conditions, several local maxima exist, e.g., near the side walls, at the intersection of bed and side wall, and just off the centre. The absolute maximum in most experiments is found 2 to $6 \mathrm{~cm}$ out of the centre. This lateral distribution of the bed shear stress can be related to the earlier described secondary current patterns, with the extra vortices near the side walls of a semi-circular cross section. This again demonstrates the importance of the secondary flow structure, but also the effect of the aspect ratio. The aspect ratio of the semicircular cross section is about half the aspect ratio for the rectangular cross section for corresponding water depths due to the limited sediment width. The narrowness of the flume enhances the influence of the side walls on the bed shear stress distribution.

The complex shear stress distributions and secondary structures cells result in different relations between, $\tau_{\text {swc }}, \tau_{\max }$ and $\tau_{\text {mean }}$ (F.K.F.O. 1994). For the circular section the centre line bed shear stress is almost equal to the average bed shear stress. This average value is about $75 \%$ of the maximum bed shear stress. The classical side wall elimination techniques overestimate even the maximum bed shear stress.

The shear stress distribution has an effect on the resulting bed forms. In the rectangular flume, the bed forms or erosion patterns, in the case of cohesive sediments, are evenly distributed along the width of the cross section or, in some cases, the erosion is more pronounced along the centre line of the flume. In the semi-circular cross section the non uniformity of the shear stress distribution over the width causes irregular bed forms. The important secondary currents close to the side walls and the associated bed shear stresses are responsible for the local erosion spots (Torfs et al. 1994). 
In the framework of the interuniversity F.K.F.O.-research project on the erosion of partly cohesive sediments, a measuring campaign was organized in the major collector sewer of Brussels (F.K.F.O. 1993). In dry weather conditions water levels, flow rates, suspended solids and velocity distributions were monitored in two cross sections. The cross section of the trunk sewer is drawn in Figure 5.14. In case of low water depth this cross section is similar to the semi-circular cross section. For higher water depth the cross section resembles a narrow rectangle.

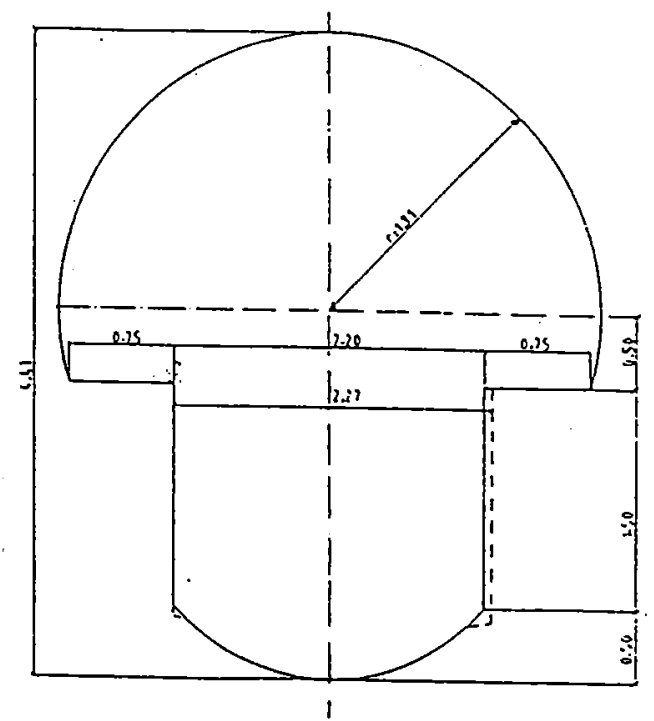

Figure 5.14: Cross section of the Brussels trunk sewer.
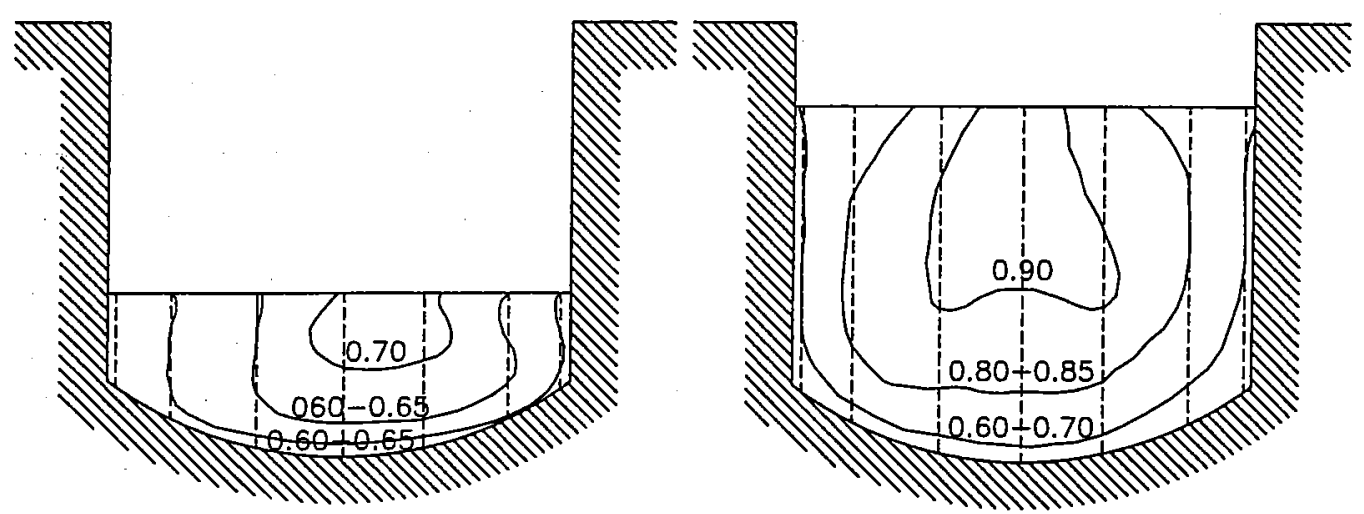

Figure 5.15: Measured iso-velocity lines for the Brussels collector. Left hand side: measurements at $4 \mathrm{a} . \mathrm{m}$., the discharge is $0.608 \mathrm{~m}^{3} / \mathrm{s}$ and the centre line water depth is $63 \mathrm{~cm}$. Right hand side: measurements at $12 \mathrm{a} . \mathrm{m}$., the discharge is $1.522 \mathrm{~m}^{3} / \mathrm{s}$ and the centre line water depth is $108 \mathrm{~cm}$.

When the measured isovel-plots are compared for low (Figure 5.15, left hand side) and high water depth (Figure 5.15, right hand side), it is clear that for increasing water depth the velocity 
dip phenomenon is more clear. As expected from the literature review and our experiments, for a semi-circular cross section no free-surface vortex is present and hence no decreasing velocities towards the free surface are measured. For a rectangular cross section, the decreasing velocities are caused by the presence of the free-surface vortex.

\subsection{Bed shear stress calculations}

The bed shear stress is one of the most important parameters in erosion and sediment transport processes. Hence, some guidelines on the calculation of shear stresses and some relations between the different bed shear stresses depending on the shape of the cross section need to be formulated.

In order to predict the onset of erosion the knowledge of the maximum bed shear stress is important. It is this shear stress that has to be compared to the erosion resistance or critical bed shear stress to estimate whether erosion will occur or not. For a rectangular narrow flume two options are open. A traditional side wall elimination technique can be used if only the average flow parameters (discharge, water level, slope of the energy line, ...) are given. The bed shear stress calculated in this way is a good estimation of the maximum bed shear stress. If an accurate velocity profile is measured along the mid vertical of the cross section, the application of the law of the wall (logarithmic Prandtl-Von Karman profile) can also lead to the maximum bed shear stress. Indeed, for a rectangular cross section the maximum bed shear stress is mostly found in the centre of the cross section. However, this method is very sensitive to the knowledge of the exact bottom or reference level and therefore cannot be used when e.g., bed forms are present. In the semi-circular flume the shear stress distributions are a lot more complex. A traditional side wall elimination calculation even overestimates the maximum bed shear stress (F.K.F.O. 1994). A modified caiculation is necessary. i.e., a side wall correction calculation starting from a known bed roughness, the so called modified Vanoni-Brooks method as explained by Kleijwegt (1992). The position of the maximum bed shear stress is mostly out of the centre $(2$ to $6 \mathrm{~cm}$ in the case of the experiments in Ghent). The maximum bed shear stress in the semi-circular cross section was found to be 1.35 times the bed shear stress obtained from the mid vertical velocity profile (F.K.F.O. 1994). 
For the calculation of sediment transport and erosion rates, the average bed shear stress is important. It is this value that needs to be filled in a transport formula. From the experiments in the flume with the rectangular cross section was learned that the average bed shear stress is about $70 \%$ of the maximum value. As mentioned above this maximum value can be obtained from a traditional side wall elimination calculation or from a measured central velocity profile. The average bed shear stress in the semi-circular flume was found to be $75 \%$ of the maximum value. The bed shear stress obtained from the mid vertical velocity profile agrees well with the average bed shear stress (F.K.F.O. 1994).

\subsection{Summary}

From a set of detailed velocity profile measurements over a rectangular and a semi-circular flume cross section, the effects of the shape of the cross section on the bed shear stress distribution are demonstrated. The influence of the side walls is more pronounced in the narrow semi-circular cross section and this leads to important secondary currents and irregular bed shear stress distributions over the cross section. As a result, higher erosion rates and locally deep scour holes along the walls are observed during the erosion tests.

Field measurements in the river Scheldt and in the major collector sewer of Brussels have confirmed these findings and have also illustrated the scale effects.

The results of the laboratory experiments have shown that the well-known side wall elimination techniques, used to calculate bed shear stresses, overestimate the average bed shear stress and are in fact in good agreement with the maximum bed shear stress over the cross section. For the rectangular cross section the maximum bed shear stress is found in the centre. The whole bed shear stress distribution, however, is quite uniform. This is not the case in the semi-circular cross section where several local maximum bed shear stresses exist, depending on the flow conditions. The average bed shear stress can be calculated as $70 \%$ of the maximum value for the rectangular flume and $75 \%$ for the semi-circular flume. The bed shear stress calculated from the central velocity profile is a good estimation for the average bed shear stress in the semi-circular cross section. The higher average bed shear stress, together with the important secondary flow causes the high erosion rates in the semi-circular flume. 




\section{Chapter 6: Modelling the erosion of mud/sand mixtures}

\subsection{Introduction}

Chapter 4 describes the results of an extensive set of experiments on the erosion of mud/sand mixtures. The experimental results demonstrate the effect of some important parameters such as mixture composition, bed density and consolidation time. Different trends in the experimental data have been discussed and a physical explanation for those trends has been put forward. The next question is of course how to apply this knowledge to practical problems in the field. These problems can be related to the design and maintenance of sewers or to the control of dredging activities and minimal navigable depths in estuaries, among others. However, the flow conditions are restricted to uniform flow.

The aim of this chapter is not to develop a completely new model for the erosion of mud/sand mixtures, but to describe a modelling strategy using the existing knowledge from cohesionless and cohesive sediment behaviour models and theories in combination with the findings from our experiments. In this chapter some guidelines will be formulated indicating when to use which type of model or formula and how to proceed.

In $\S 6.2$ the estimation of the bed shear strength is discussed. The erosion resistance of a sediment bed determines when, in which flow conditions, the flow will start to erode the bed. The bed shear strength and its variations within the sediment bed are necessary inputs to calculate erosion rates. The calculation and prediction of erosion rates is the subject of the next paragraph ( $\$ 6.3$ ). Depending on the composition of a mud/sand mixture, this mixture can be cohesionless or cohesive. Hence, sediment transport formulas for cohesionless or cohesive sediments can be used, if the correct parameters and coefficients are introduced.

The last question about modelling and predicting the erosion of mixed sediments in sewers or estuaries and tidal rivers, is which information about the flow field and about the sediment bed is needed to make reliable calculations and estimations of the erosional properties ( $\$ 6.4)$. 


\subsection{Modelling the erosion resistance of mud/sand mixtures}

\subsubsection{Introduction}

The stability of a sediment bed under certain flow conditions is an important aspect of practical sediment transport problems, whether related to rivers, estuaries or sewers. Hence, engineers have always looked for a practical way to predict the erosion resistance of a certain sediment bed. As mentioned in Chapter 2, simple empirical criteria exist for uniform cohesionless sediments, where the erosion resistance is only a function of the grain size of the material. For cohesive sediments a number of empirical formulas have been developed. However, their reliability is much smaller and usually some laboratory or field tests are required for each type of sediment. Based on the experimental data of this study, the next paragraph ( $\$ 6.2 .2$ ) will discuss the possibilities to predict the erosion resistance of mud/sand mixtures. In $\S 6.2 .3$ a general formula to calculate the critical shear stress for erosion is presented and its applicability in the case of mud/sand mixtures will be studied. In a last paragraph $(\$ 6.2 .4)$ the findings related to the prediction of the erosion resistance of mud/sand mixtures are summarized.

\subsubsection{Erosion resistance as a function of mixture composition}

The main objective of this study has been to look at the transition from cohesionless to cohesive behaviour of mixtures by gradually increasing the fraction of cohesive material (\%fines) in a mixture. As far as erosion resistance is concerned, the experimental study came up with the following results that are schematically represented in Figure 6.1: at very low \%fines the erosion resistance is slightly smaller than for sand only, at a higher content of fines the erosion resistance seems to increase more or less linearly in two steps. To visualize the different structures formed inside the sediment bed, which are responsible for the changes in erodibility, Plates $3 a$ until e show pictures of different kaolinite mixtures ( 5 until $20 \%$ fines) taken by a scanning electron microscope. Kaolinite clay was choosen as the cohesive material in order to avoid the effects of organic material, so that only the bonding mechanisms caused by increasing the cohesive fraction 
in the sediment mixture are focussed. One of the disadvantages of the electron microscope technique is that the samples need to be completely dry. The drying process has certainly an effect on the observed structure, however, the plates can still visualize the effect of increasing \%fines on the sample. The samples shown in Plates 3 to 6 are slowly air-dried, to minimalize the effects of the drying process. The most important effect of drying the sample is the formation of a kaolinite layer covering the sand particles (Plates 4\&6). During the evacuation of the water, the kaolinite particles and flocs settle out and deposit onto the sand grains.

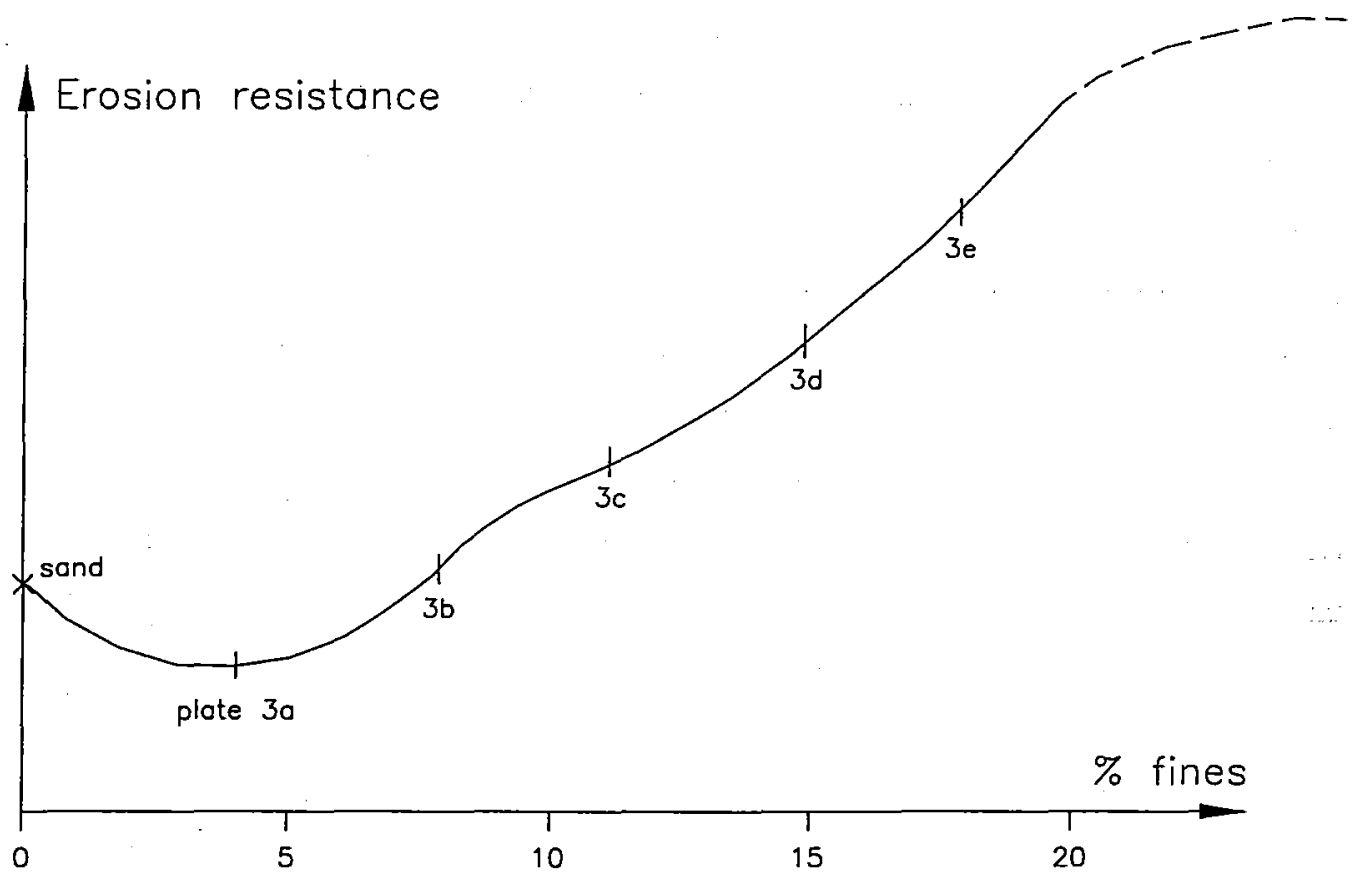

Figure 6.1: Erosion resistance of mud/sand mixtures as a function of the amount of fines.

Using these pictures taken by the scanning electron microscope, the evolution of the critical shear stress as a function of the amount of fines can be explained as follows. When a small amount of fines is added to sand, the fines are washed out from the top layer at a lower bed shear stress than needed to move the sand. The sand grains themselves will only be eroded, once the critical shear stress for sand has been exceeded: sand erosion and transport is not significantly changed by the presence of the fines. The sand grains are still in contact with each other, the cohesive particles only fill a small part of the pore spaces in between the grains (Plate 3a). In fact, these mixtures can be treated as mixtures of cohesionless sediments. The critical shear stress for the fines in between the sand particles will be higher than expected from a uniform bed of only 
(cohesionless) fine particles of that size. The fines are hiding in between and are protected by the sand grains and hence, they are more difficult to erode.

When the amount of fines in the mixture increases, the fine particles will fill more and more of the pore volume (Plate $3 b$ ). At the sediment surface, this leads to smoothening of the bed. As a result the turbulence decreases and the stochastical variations of shear stress diminish as well. The flow has less effect on the smooth surface: looking at the Shields curve (Figure 2.2) it can be seen that for low values of $\mathrm{Re}_{*}$, a decreasing hydraulic roughness leads to an increasing erosion resistance. Possibly, the fines at the surface will even start to form some network structure, resisting the flow even more (Plate $3 b$ ). However, on the average, there is still contact between the sand grains and the mixture cannot yet be considered to be cohesive. Locally, some "bridges" between sand particles are formed (Plate 4a\&b): the small clay particles ( $75 \%$ of the kaolinite is smaller than $2 \mu \mathrm{m})$ get stuck in irregularities on the surface of the large $(230 \mu \mathrm{m})$ sand grains. The clay particles attract others and soon a large floc is formed that can get trapped in a narrow bottleneck in between to sand grains: a bridge is formed; this growing process is clearly demonstrated in Plate 7. Depending on the amount of fines in the mixture the clay bonds in between two sand grains range from some small threads (Plate 4a) to a complete connection of the two sand particles (Plate 4d) via some intermediate stages (Plates $4 \mathrm{~b} \& \mathrm{c}$ ).

As soon as a certain limit of fines in the mixture is exceeded, the contact between the sand grains is broken (Plates $3 c \& d$ ). The fines start to cover the sand grains, in the beginning only partially, and a network is created linking all particles into a coherent structure. The mixture is considered to be cohesive. The erosion resistance keeps increasing with increasing amount of fines: the small bridges between the grains convert into complete networks of the cohesive particles around the sand grains (Plate 4c\&d). In our experiments the limit, above which the cohesion starts to dominate the erosion process, is found to be between 5 to $15 \%$ of fines, depending on the type of cohesive sediment. Alvarez (1990) found for his experiments on Laponite/sand mixtures a limit of $15 \%$, above which the sand particles are covered with a clay suspension and cohesion becomes important. Willis et al. (1994) used $20 \%$ of mud as critical amount delimiting mostly sand or mostly mud behaviour in their mathematical model. 
In fact it is not so much the \%fines, i.e., the mass of fines, that determines whether a mixture becomes cohesive, but it is the volume fraction of the fine particles. Indeed, the critical mixture composition is reached when the fines are filling up the pore spaces in the sand skeleton and the sand grains loose contact with each other.

The \%fines has been defined as the ratio between the amount of fines by weight and the total mass of dry sediment, which corresponds to the ratio between the volume of the the fines $\left(V_{f}\right)$ and the total volume of dry sediment $\left(\mathrm{V}_{\mathrm{f}+\mathrm{s}}\right.$, fines and sand) if we assume that the sand grains and the fine particles have the same density of about $2650 \mathrm{~kg} / \mathrm{m}^{3}$; i.e., \%fines $=\frac{V_{f}}{V_{f+s}}$

The volume fraction of the fine particles $\left(\phi_{f}\right)$ in the total mixture of sediments and water can be calculated as:

$\phi_{f}=\frac{V_{f}}{V_{f+s+w}}=\frac{\% \text { fines } V_{f+s}}{V_{f+s+w}}$, with $V_{f+s+w}$ the total volume of the mixture, including the pore water.

The ratio between sediment volume $\left(V_{f+s}\right)$ and total volume $\left(V_{f+s+w}\right)$ is by definition the volume fraction of the sediment mixture $\left(\phi_{\mathrm{a}}\right)$, hence, the volume fraction of the fine material can be expressed as: $\phi_{f}=\%$ fines $\phi_{a}$

In case of a mixture density of $1800 \mathrm{~kg} / \mathrm{m}^{3}$, the value of $\phi_{a}$ is about 0.49 . This means that.a critical \%fines of $10 \%$ by weight corresponds to a volume fraction of only $5 \%$. Five percent of fine material is enough to change a cohesionless sediment into a cohesive mixture. For pure mud, without an addition of sand, $\phi_{\mathrm{f}}=\phi_{\mathrm{a}}=0.06$ corresponds to the gel point density (around $\left.1100 \mathrm{~kg} / \mathrm{m}^{3}\right)$ at which the mud develops internal structure and strength.

If we assume that the sand used in our experiments has a porosity of 40 to $45 \%$ (van Rijn 1989), the sand grains will loose contact when the total amount of mud and water exceeds $40 \%$ by volume. Mostly the water content of the homogeneous mixtures varied between 25 and $30 \%$ by weight or around $35 \%$ by volume, so this rough estimation would lead again to a maximum mud percentage of about $5 \%$. Raudkivi (Panagiotopulos 1995) found the following expression to calculate the clay fraction ( $\mathrm{C} \%$, by weight) necessary to fill the pores of a soil at a given water content ( $\mathrm{w} \%$ ): $\mathrm{C}=48.4-1.42 \mathrm{w}$. This would lead to $\mathrm{C}$ around $10 \%$. These data and estimations indicate that, depending on the type of sand and cohesive material involved and their grain size 
distributions, 10 to $20 \%$ fines (by weight) or only about $5 \%$ (by volume) -as derived from our experiments- can indeed be taken as the limit between cohesionless and cohesive behaviour of a certain mixture. Above this limit a network of cohesive bonds is formed in the sediment and at lower \%fines the erodibility is dominated by interlocking and gravity of the sand grains.

Increasing the fines content above that limit (Plate $3 \mathrm{e}$ ) the mixture becomes in fact a cohesive matrix in which some sand grains are trapped. The mud fraction is the major fraction governing the erodibility; the effects of increasing the \%fines will gradually decrease and reduce to zero. This would explain the existence of a maximum critical shear stress as found by Alvarez (1990).

The samples shown in Plate 5a\&b are the same as $3 \mathrm{~d} \& \mathrm{e}$ but broken, to check if the observed phenomena are not just surficial effects. Both plates demonstrate that networking and bridge formation are present throughout the whole sample. Plate 6 shows some strong enlargements of the clay matrix. The clay particles, plates, are randomly oriented, a bit like the expected card house like structure, although the structure partly collapsed during the evacuation of the water. The sample in Plate 7 was quickly dried at a temperature of $105^{\circ} \mathrm{C}$. The enlargement of the clay matrix in Plate 7c shows that the clay particles are more parallel oriented. The structure collapsed completely during the rapid drying process.

This physical description of the effect of mixture composition on erosion resistance is able to explain most of the phenomena encountered in this study or reported by other authors. Our experiments have indicated significant differences in the erodibility for the different types of cohesive sediments that were used ( $\$$ 4.3.3). The mixtures with kaolinite clay showed the highest critical shear stresses when mixtures containing the same amount of fines are compared. The kaolinite clay is very fine and consists of more than $75 \%$ clay particles (i.e., smaller than $2 \mu \mathrm{m}$, see the grain size distribution in Figure 3.7). The fines will fill the pores in between the sand grains and smoothen the surface, but it is the clay fraction that is responsible for the formation of cohesive bonds. Therefore, for the same \%fines, the kaolinite mixtures are likely to be the most cohesive and hence, the most resisting to erosion.

On the other hand, the montmorillonite mixtures are more erodible than the mud mixtures, although the montmorillonite contains more clay particles (about $30 \%$ ) than the muds (about 10 
to $15 \%$ ). This can be explained by the organic content of the mud, which leads to additional adhesion and organic binding of the sand particles.

Another consequence of the proposed model is that also the influence of the sand grain size can be estimated. Indeed, finer sand grains are more easily covered by the fine particles and hence, the limit of cohesive behaviour will be lower, whereas the erosion resistance for an equal amount of fines will be higher. This was demonstrated by the experiments of Panagiotopoulos et al. (1995). They used two types of mono-sized quartz sand having a $d_{50}$ of 152.5 and $215 \mu \mathrm{m}$. The erosion experiments under uniform flow conditions showed significantly higher critical shear stresses for the mixtures with the finest sand. Moreover, it can be expected that for sand with lower porosities also the limit of cohesive behaviour will decrease.

On the other hand, small amounts of sand added to mud also seem to increase its erosion resistance (Alvarez 1990, Amos et al. 1994, Williamson et al. 1992). As mentioned in $\S 4.3 .3$ the increased erosion resistance is the result of increased bed density and the changes in the structure of the mixture, which are probably becoming more important than the decreasing cohesion. These aspects have not been studied in detail in this thesis.

\subsubsection{Prediction of the critical shear stress for erosion}

In the previous paragraph the mechanisms responsible for the erosion resistance of mud/sand mixtures have been described and explained. In order to predict the erodibility of a certain sediment bed, an expression for the critical shear stress for erosion has to be developed. Notwithstanding the stochastic nature of the erosion process, the concept of a critical shear stress as one particular value related to a certain sediment bed, remains very useful for many sediment transport models. Therefore, a deterministic expression for the critical shear stress will be generated in this paragraph, which is based on the (time) averaged values of the parameters involved. At the end, however, we will briefly indicate how stochastics can be introduced. 


\section{A. Incipient motion criterion for uniform sediment}

In $\S 2.2 .1$ and $\S 2.3 .2$ a similar approach was used to develop an erosion criterion for both cohesionless (equation (2.3)) and cohesive sediments (equation (2.35)) starting from an analysis of the forces acting on a particle. Mehta and Lee (1994) tried to link the threshold conditions for transport of cohesionless and cohesive grains. For uniform sediments with non-deformable grains which possess a physically recognizable identity, a general force analysis was carried out. In Figure 6.2 all forces acting on a sediment grain on the surface of a cohesionless or cohesive bed in uniform flow are represented at incipient motion conditions. Both D (drag force) and L (lift force) depend on the flow conditions (and particle shape) and are proportional to $u_{t}{ }^{2}, u_{t}$ is considered to be the velocity at the top of the grains. $F_{a}$ is the active force, which incorporates all interparticle forces, not only physico-chemical bonds but also other adhesive mechanisms, e.g., organic binding.

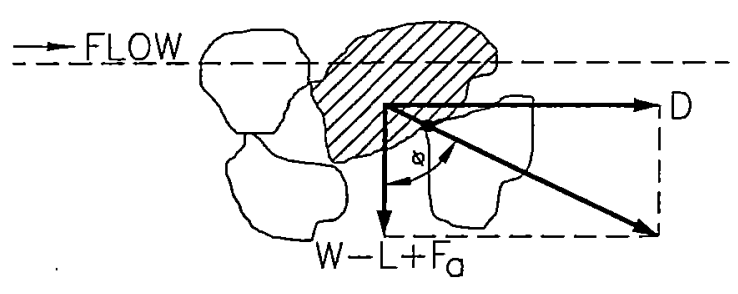

Figure 6.2: Forces acting on a sediment grain at the surface of a bed at incipient motion conditions (Mehta et al. 1994).
The resultant of all active forces will act, by definition, through the point of intergranular contact. This resultant must subtend an angle $\phi$ with the downward forces. This angle $\phi$, the angle of repose, has a clear physical meaning for cohesionless sediments. For cohesive materials, $\phi$ becomes a coefficient that embodies shear resistance. Interparticle contacts can be broken by shear and/or normal forces.

Using the time average values of the forces depicted in Figure 6.2, a general deterministic criterion for incipient motion of uniform grains can be written as:

$$
\tan \phi=\frac{D}{W+F_{a}-L}
$$

As discussed in $\$ 2.2 .1$, the lift and drag forces in the previous equation can be expressed as a function of $\tau_{c r}$, the average bed shear stress at incipient motion. In case of a hydraulically rough bed, the following expressions are used: $D=\alpha_{1} \tau_{c r} d_{e}^{2}$ and $L=\alpha_{2} \tau_{c r} d_{e}^{2}$, with $\alpha_{1}$ an area shape 
factor and $\alpha_{2}=\alpha_{1} C_{L} / C_{D}$. The buoyancy force $W=\alpha_{3} g\left(\rho_{s}-\rho\right) d_{e}^{3}$, with $\alpha_{3}$ a volumetric shape factor. Furthermore, Christensen (1972) derived an equation for $C_{L} / C_{D}$, see equation (2.2).

Mehta et al. (1994) developed their theory for non deformable grains. When cohesive flocs at the bed surface deform elastically under shear flow, the drag forces are reduced. For smooth bed conditions, e.g., for a soft cohesive sediment bed, Dade et al. (1992) proposed the following expressions for drag and lift forces: $\mathrm{D}=8.0 \rho v^{2} \mathrm{Re}_{*}{ }^{2}=\alpha_{1} \tau_{\mathrm{cr}} \mathrm{d}_{\mathrm{c}}{ }^{2}\left(\alpha_{1}=8.0\right)$ and $\mathrm{L}=0.81 \rho v^{2} \mathrm{Re}_{*}{ }^{3}$ $=0.81 \tau_{\mathrm{cr}} \mathrm{d}_{\mathrm{c}}{ }^{3} / v$, which means that $\alpha_{2}$ is a function of $\mathrm{d}_{c}$ and $v$. Indeed, for small values of $\mathrm{Re}_{*}$, or for a hydraulically smooth boundary, the drag and lift coefficient are a function of Re., $C_{D}=24 / \operatorname{Re}$ (Berlamont 1981). The above expressions for drag and lift forces can still be used for smooth boundaries but the appropriate coefficients need to be filled in. To relate the viscous drag and lift forces acting on actual particles rather than spheres, another shape factor $b_{1}$ needs to be introduced. For oblate particles, Dade et al. (1992) suggested:

$$
b_{1}=\frac{\sqrt{1-R^{2}}}{R^{1 / 3} \cos ^{-1} R}
$$

with $R$ the aspect ratio of the actual particle, $r_{1} / r_{2}$ with $r_{1}$ the particle radius along the axis of symmetry. For prolate particles:

$$
b_{1}=\frac{\sqrt{R^{2}-1}}{R^{1 / 3} \ln \left[R+\sqrt{R^{2}-1}\right]}
$$

$b_{1}$ expresses the ratio between drag forces acting on a particle and drag forces acting on a sphere of equivalent volume and hence can be incorporated in $\alpha_{1}$ and $\alpha_{2}$.

Using these expressions, $\tau_{c r}$ "the" critical shear stress, used in practical applications, can be written as:

$$
\frac{\tau}{g\left(\rho_{s}-\rho\right) d_{e}}=\frac{\alpha_{3} \tan \phi}{\left(\alpha_{1}+\alpha_{2} \tan \phi\right)}+\frac{F_{a} \tan \phi /\left(\alpha_{1}+\alpha_{2} \tan \phi\right)}{g\left(\rho_{s}-\rho\right) d_{e}^{3}}
$$

The left hand side of equation (6.4) is the Shields parameter or dimensionless bed shear stress. For cohesionless grains $F_{a}=0$, the equation reduces to equation (2.3) that can be graphically 
represented by the Shields diagram (Figure 2.2, see also the remarks made there, concerning the relation with the grain Reynolds number).

For cohesive sediments, equation (6.4) resembles the Coulomb equation $\tau=\sigma^{\prime} \tan \phi+C$. Indeed the equation can be seen as a form of Coulomb's equation for the bed surface where there is no effective stress (Mehta et al. 1994). For practical use, one can rewrite the equation:

$$
\frac{\tau}{g\left(\rho_{s}-\rho\right) d_{e}}=\theta+\frac{\tau_{s}}{g\left(\rho_{s}-\rho\right) d_{e}}
$$

in which $\tau_{s}$ is defined as the shear strength of the material. This shear strength cannot be estimated or calculated easily and must be determined experimentally for each specific sediment. However, in $\S 2.3 .2$ different possibilities to predict $\tau_{s}$ (Mehta 1988, Mehta et al. 1994) from the density of the bed are discussed: equations (2.33) and (2.34). Anyway, the equation reduces to $\tau_{\mathrm{cr}}=\tau_{\mathrm{s}}$ for cohesive material, assuming that the parameters in $\theta$ are cohesion dependent and can be incorporated in $\tau_{\mathrm{s}}$.

For uniform sediments Mehta et al. (1994) found that the incipient motion behaviour changes rather abrupt from cohesionless to cohesive sediments around $20 \mu \mathrm{m}$. The results of this experimental study ( $\$ 6.2 .2$ ) indicate that for mud/sand mixtures the limit between cohesioniess and cohesive behaviour lies around 10 to $20 \%$ fines in the mixture.

Going back to equation (6.4), in order to calculate the critical shear stress, a number of parameters and coefficients need to be determined or measured. The coefficients $\alpha_{1}$ and $\alpha_{3}$ depend on the grain size distribution, the shape and the arrangement of the particles in the surface layer. Those coefficients are related to the equivalent diameter of the bed material $\left(d_{e}\right)$. Also the density of the particles has to be defined. The sediment density $\rho_{s}$ is considerably smaller for cohesive flocs $\left( \pm 1020 \mathrm{~kg} / \mathrm{m}^{3}\right)$ than for cohesionless grains $\left(2650 \mathrm{~kg} / \mathrm{m}^{3}\right)$. The coefficient $\alpha_{2}$, which is proportional to the ratio of drag and lift coefficients has to be calculated, using the appropriate equation for either rough or smooth conditions. Furthermore, the particle packing angle $\phi$ and the 'cohesive' force $F_{a}$ or the shear strength $\tau_{s}$ need to be determined. For cohesionless sediments, the particle angle of repose is a strictly defined characteristic of the sediment. Wiberg et al. (1987) found values between $50^{\circ}$ and $60^{\circ}$, for uniform sediments, depending on the shape and angularity of the grains. For cohesive sediments, a greater variety 
of values is found ranging from $40^{\circ}$ to $80^{\circ}$ (Amos et al. 1992). Dade et al. (1992) proposed $\phi \approx 65^{\circ}$ for natural mud, typically poorly sorted. In $\S 2.3 .2$ an empirical equation by Dade et al. (1992) is discussed where $F_{a}$ is calculated from a measured yield stress: equation (2.37).

The force analysis discussed above only deals with a particle at the surface of a sediment bed. It is important to state that for cohesive soils two different erosion mechanisms exist ( $\$ 2.3 .2)$, each with a corresponding critical shear stress for erosion. When particle by particle is removed from the surface, as described above, this process is called surface erosion. The second erosion mechanism for cohesive sediments is mass erosion. For dense, consolidated cohesive soils subjected to high shear stresses the bed may erode by dislodgement of large shreds, crumbs of material. The eroded entities are much larger that the floc or particle dimensions. The erosion does not occur at the surface but at a plane in the bed. The same equations could be used to calculate the critical shear stress in that case, provided the appropriate density and dimensions of the "particles" are used.

A last remark related to the use of equation (6.4) is that the formula cannot be used in the case of very soft cohesive beds, fluid mud, where no interparticle contacts exist. The fluidization of a cohesive sediment bed and re-entrainment of fluid mud falls outside the scope of this thesis.

\section{B. Sediment mixtures}

The erosion criterion developed in the previous paragraph can only be applied as such for uniform sediments, or quasi-uniform sediments, that can easily be characterized by an equivalent grain size. However, natural sediments are often poorly sorted and consist of a wide variety of grain sizes.

\section{i Cohesionless sediments}

Small grains, hidden between larger grains, are much harder to erode than large particles on top of the bed consisting of smaller grains. The relative protrusion of the different particles is an important factor that determines the erodibility of the sediment mixture. Einstein 
(Berlamont 1981) applied correction factors for non uniform sediments. He reduced the lift force by $1 / \zeta$ for small grains, to account for the hiding effect. $\zeta$ is a function of $d / x$, i.e., the ratio between the diameter of the grain under consideration and $x$, a parameter that incorporates the transition from hydraulically smooth to rough beds. Einstein also reduced the lift force by a factor $Y$, that represents the changes in lift force due to a mixture of different roughnesses. $Y$ is a function of $\mathrm{k}_{\mathrm{s}} / \delta$, with $\mathrm{k}_{\mathrm{s}}$ the roughness coefficient for the sediment bed and $\delta$ the thickness of the laminar sublayer.

(a)

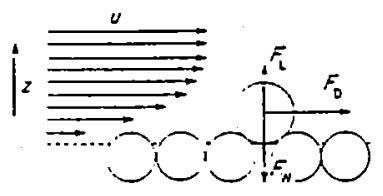

(b)

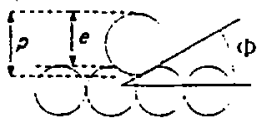

(c)

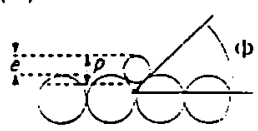

(d)

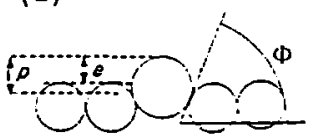

(e)

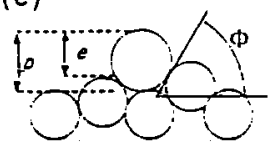

Wiberg et al. (1987) and Kirchner et al. (1990) studied an extensive set of data on the critical shear stress of heterogeneous cohesionless sediments. They found that particles at the surface of a poorly sorted bed can have critical shear stresses that differ significantly from the critical shear stress associated with that particle when placed on a well-sorted bed of the same grain size. These differences are primarily Figure 6.3: Variation of the different factors due to the relative protrusion of the particle affecting the force balance: friction angle $(\phi)$, grain projection (p) above the mean local bed level and grain exposure (e) above the local upstream surface (Kirchner et al. 1990).

into the flow along with differences in the particle angle of repose and bed pocket geometry, that results from having different sizes in the bed (see Figure 6.3). When the diameter $D$ of the particle is smaller than $k_{s}$, the overall roughness of the bed, the critical shear stress increases. For $\mathrm{D} / \mathrm{k}_{\mathrm{s}}>1$, the grains become more mobile. The following relation between friction angle and $D / k_{s}$ was put forward by Kirchner et al. (1990):

$$
\phi=\alpha\left(\frac{\mathrm{D}}{\mathrm{k}_{\mathrm{s}}}\right)^{-\beta}
$$


However, analytical predictions of $\phi$ and the relative protrusion of a heterogeneous sediment based on its grain size distributions are not possible, unless for artificially simplified pocket geometries that bear no resemblance to textures in natural sediments.

Using an equation similar to equation (6.4), Wiberg et al. (1987) calculated the critical bed shear stress. In Figure 6.4 the calculated critical shear stresses are compared for different values of $\mathrm{D} / \mathrm{k}_{\mathrm{s}}$. The plot shows that the critical shear stresses for different particles in a mixture do not vary significantly, although the relationship does change with $\mathrm{Re}_{*}\left(\mathrm{R}_{*}\right.$ in the Figure). For coarse materials (high $\mathrm{Re}_{*}$ ), grains with diameters ranging form 0.2 to 4 times the roughness of the bed, have almost equal mobility. Kirchner et al. (1990) found also that all grain sizes in a heterogeneous cohesionless sediment will start to move at nearly the same bed shear stress: the erosion of the coarser fractions tends to mobilize the smaller fractions while the erosion of fines probably inhibits the entrainment of the coarser grains.

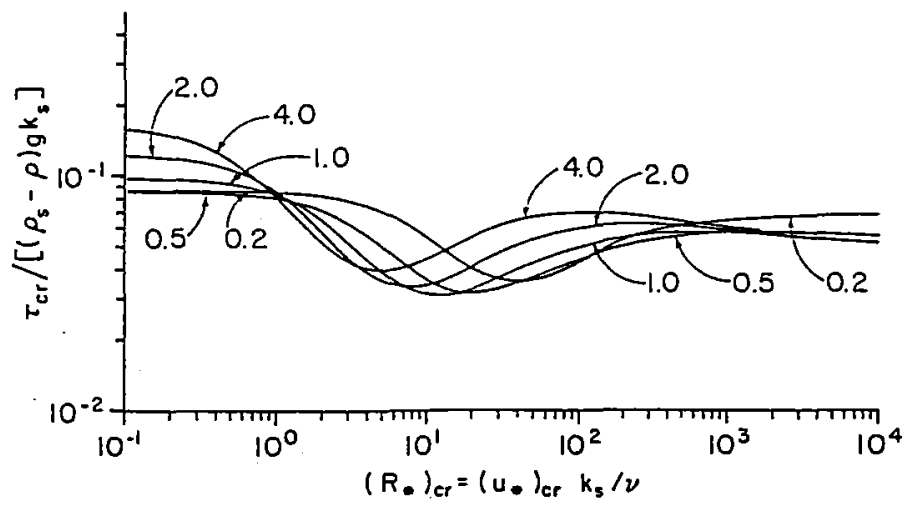

Figure 6.4: Calculated critical shear stresses as a function of the wall Reynolds number $\left(R_{*}\right)$ for different values of $\mathrm{D} / \mathrm{k}_{\mathrm{s}}$ (Wiberg et al. 1987).

\section{ii Cohesive sediments}

Dade et al. (1992) followed a similar force analysis to determine the erosion resistance of muds, leading to an equation comparable to equation (6.4). According to them the relative protrusion of the different particle sizes is incorporated in $\operatorname{tg} \phi$, although little is known about the particle packing angle for plate-like grains in random orientation. Following the results of Wiberg et al. 
(1987), they also assume an almost equal erodibility for the different sizes in a heterogeneous mud. As mentioned before, they found that natural mud, typically poorly sorted, can be analysed in terms of $\phi \approx 65^{\circ}$. However, in their proposed method to calculate $F_{a}$ from a measured yield stress (see $\S 2.3 .2$ ), the effects of relative protrusion and changes in effective contact surface area have been incorporated in the calculated force $F_{a}$.

\section{iii Mud/Sand mixtures}

From field experiments by Amos et al. (1994) on the erosion of natural mud/sand mixtures, a relation between the surficial friction angle $\phi$ and the clay content of the sediment of the surface layer was deduced, as plotted in Figure 6.5: the friction angle $\phi$ decreases with increasing clay content. The threshold for erosion increases with increasing friction angle.

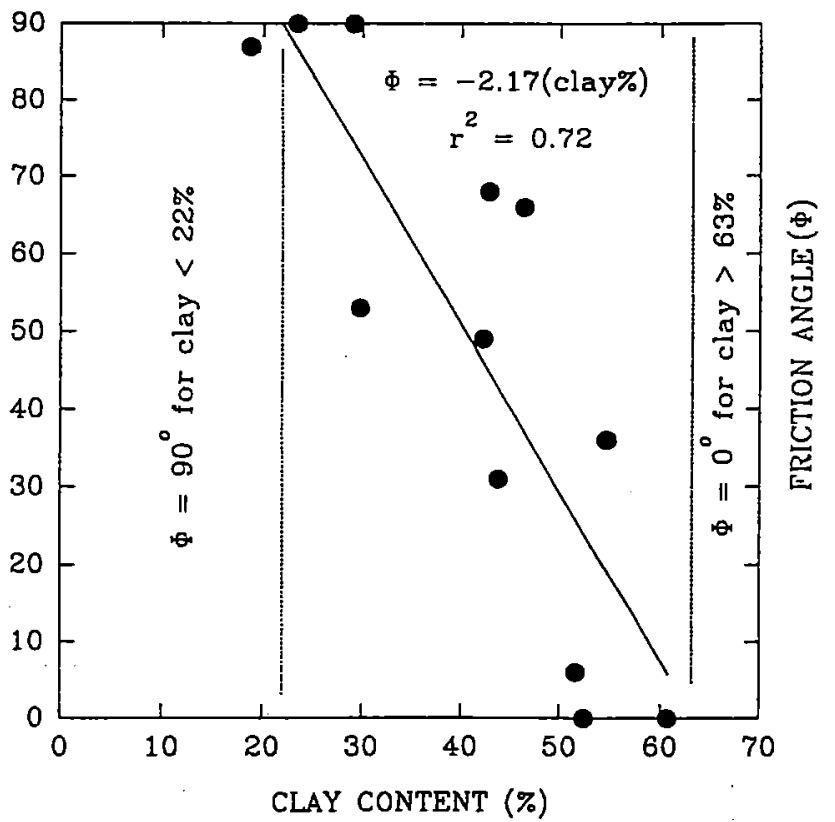

Figure 6.5: Measured friction angle versus clay content (Amos et al. 1994).

In our experiments friction angles or bed topography have not been measured. However, depending on the amount of fines, the mixtures can be divided into cohesionless and cohesive sediments. In the cohesionless mixtures a small amount of fine particles are hiding in between the sand grains. Only the surficial fines will be easily washed out, i.e., at low bed shear stresses. 
For the remaining mixture, the principle of equilibrium mobility, as explained above, can be applied. For the cohesive mixtures the situation is more complicated. The bed surface will probably be smooth, hence, relative protrusion of particles will be less important and can be incorporated in the cohesive force. This cohesive force will be increasing with increasing content of fines and will eventually dominate the erosion resistance.

\section{Comparison with measured data}

To check the validity of equation (6.4) for mud/sand mixtures, it has been applied to the kaolinite mixtures. Since the equation contains a lot of unknown coefficients, a number of assumptions need to be made. First of all, the sediment bed is considered to be smooth at incipient motion conditions, even for sand only. Indeed, for the used sand, $\tau_{b}<0.5 \mathrm{~Pa}$ corresponds to $u_{*}<0.02 \mathrm{~m} / \mathrm{s}$ and with $d_{c}=d_{50}=0.23 \mathrm{~mm}$, it can be shown that $\mathrm{Re}_{*}<5$. This means that expressions for the drag and lift forces on smooth boundaries have to be used: $\alpha_{2} / \alpha_{1}=0.1 \mathrm{Re}$.. The volumetric shape factor $\alpha_{3}$ will be taken equal to $\pi / 48$, for spheric particles (Dade et al. 1992).

\section{i Cohesionless mixtures}

When the amount of fines is very small, the sediment is in fact uniform sand. If we assume $\phi=55^{\circ}$ (Wiberg et al. 1987), a sediment density of $2650 \mathrm{~kg} / \mathrm{dm}^{3}, \mathrm{~d}_{c}=\mathrm{d}_{50}=0.23 \mathrm{~mm}$ and $\mathrm{F}_{\mathrm{a}}=0$, the calculated critical shear stress for spheric particles in a simplified geometry is $0.26 \mathrm{~Pa}$. This value lies in between the value predicted by the Shields diagram $(0.20 \mathrm{~Pa})$ and the measured value $(0.35 \mathrm{~Pa})$. By trial and error a shape coefficient $b_{1}=0.75$ is determined so that the calculated critical shear stress equals the measured value. Of course the shape of the particles is not the only cause of the difference between the measured and the calculated value. The chosen friction angle, equivalent grain size and lift and drag coefficients can be erroneous as well as the measured critical shear stress. However, all the following calculations will be based on the above assumptions.

The decreasing erosion resistance for small \%fines is the result of the erosion of the fines at lower critical shear stresses, which in turn provokes the erosion of the sand grains as explained by Kirchner et al. (1990). 


\section{ii Cohesive mixtures}

When the amount of fines increases, the mixture becomes cohesive and the cohesive force $F_{a}$ needs to be included. The $\mathrm{d}_{50}$ of the mixture decreases but, if the measured grain size distributions of the sand and the clay are linearly composed, a mixture of $25 \%$ fines will still have $\mathrm{a} \mathrm{d}_{50}$ of $0.20 \mathrm{~mm}$. For mixtures containing less than $25 \%$ fines, the major proportion of the mixture is still the sand grains, hence, the equivalent diameter $d_{e}$ is chosen to be $0.21 \mathrm{~mm}$. Since we do not possess detailed information on the friction angles and the internal geometry of the mixtures, the values of $\phi=55^{\circ}$ and $b_{1}=0.75$ have not been changed. The cohesion will increase with increasing clay content of the mixture, but no measurements of its magnitude exist.

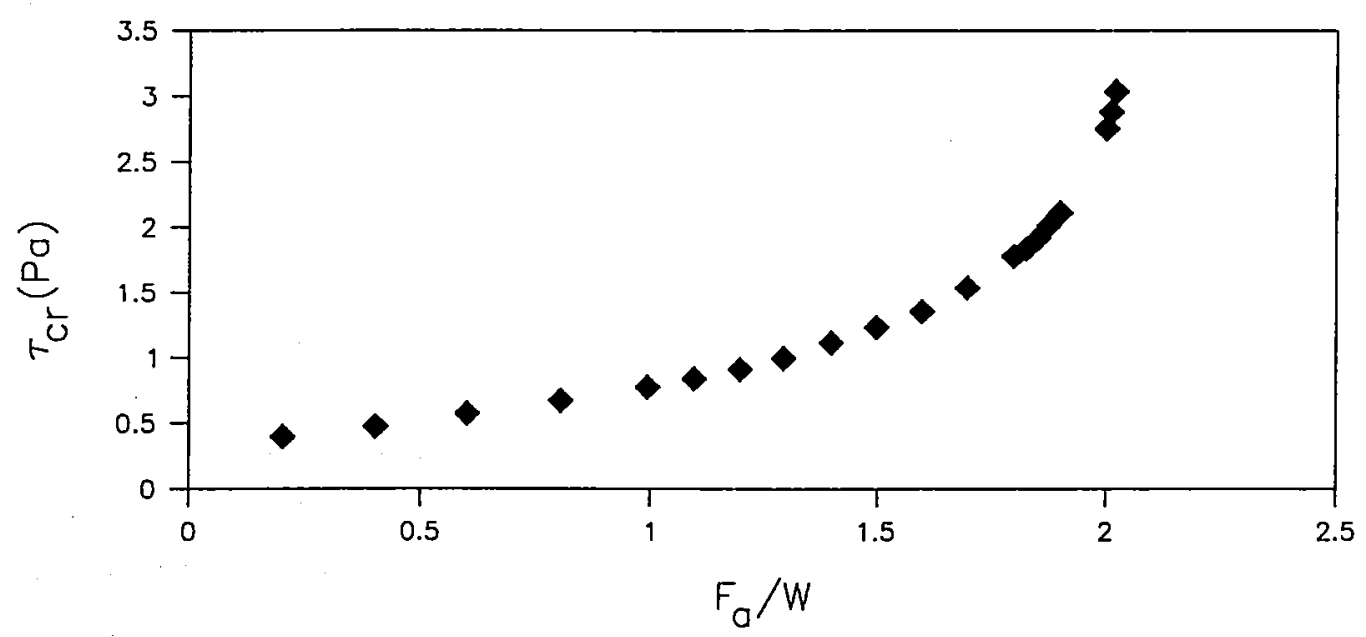

Figure 6.6: Calculated critical shear stress as a function of the relative magnitude of the cohesive force.

Therefore, the critical shear stress is calculated as a function of $\mathrm{F}_{\mathrm{a}} / \mathrm{W}$, the ratio between cohesion and gravity of the particles. For cohesive sediments $\mathrm{F}_{\mathrm{a}}$ will be greater than $\mathrm{W}$. The results are presented in Figure 6.6. It can be seen that once $\mathrm{F}_{\mathrm{a}} / \mathrm{W}$ exceeds 1.5 to 2 , the erosion resistance increases rapidly. Of course these calculations were made assuming that $\mathrm{F}_{\mathrm{a}} / \mathrm{W}$ is the only variable. Probably, the friction angle and the equivalent grain size will decrease together with the density of the eroded "particles", which will compensate the strong increase of the calculated critical shear stress. If the results of these calculations are compared to the measured critical shear 
stresses in Figure (4.7) a relation between $\mathrm{F}_{\mathrm{a}} / \mathrm{W}$ and the mixture composition can be derived by linear regression for \%fines between 9 and $15 \%$ :

$\mathrm{F}_{\mathrm{a}} / \mathrm{W}=0.04 \%$ fines $+1.43, \mathrm{r}=0.96$

indicating that the relative magnitude of the cohesive force increases with $4 \%$ per $\%$ increase of the amount of fines. The calculated critical shear stress for $F_{a} / W=1$, corresponds to value measured for a mixture containing $6 \%$ fines, which coincides very well with our experimental findings of the limit between cohesionless and cohesive behaviour for kaolinite mixtures.

Using the assumption by Dade et al. (1992), indicating that $\mathrm{F}_{\mathrm{a}}$ can be calculated from a measured yield stress, we will try to calculate the yield stress corresponding e.g., to $\mathrm{F}_{\mathrm{a}} / \mathrm{W}=2$ (\% fines $=$ $14.3 \%$ ). Equation (2.37) results in $\tau_{y}=5.56 \mathrm{~Pa}$, which is an acceptable but rather low value for a dense cohesive bed. Probably, the errors made in the choice of the applied coefficients are responsible for this low value.

\section{iii Transition}

In the transition zone from cohesionless to cohesive behaviour two phenomena occur. The smoothing of the surface increases, which makes the sediment harder to erode. A smoother bed means smaller values of Re., which in turn (Figure 6.4) results in higher critical shear stresses for the smaller particles. At the same time gradually some cohesive bridges between the sand grains are formed. Hence some cohesive force needs to be included but $\mathrm{F}_{\mathrm{a}} / \mathrm{W}$ will be smaller than 1, gravity is the predominant force. Figure 6.6 shows a smaller but still significant increase of the calculated critical shear stresses with increasing importance of the cohesion. A combination of both effects explains the measured critical shear stresses of Figure 6.1.

\section{The probability for erosion}

Due to turbulence, bed shear stresses and hence critical shear stresses, have to be treated as stochastic parameters and a expression for the probability for erosion needs to be considered. Using equation (6.4), the stochastics can be introduced in a similar way as was explained in $\S 2.1$ for cohesionless sediments. The shear stress can be expressed as a function of the velocity $u_{t}$ at the top of the grains. This velocity is fluctuating in time and a normal distribution for those 
fluctuations is assumed, with $\frac{\sigma_{u}}{\overrightarrow{\mathrm{u}}}=0.164$ (Christensen 1965). Einstein (Berlamont 1981) determined the distance $z$ at which the velocity $u_{t}$ has to be calculated (for rough beds): $z=0.35 d_{35}, d_{35}=$ the diameter of which $35 \%$ of the material is finer. Mehta and Christensen (1983) stated that the velocity at the top of the grains, $u_{t}$, is taken at a distance $z$, which can be calculated as a fraction $\mathrm{q}$ of the effective grain size, $\mathrm{z}=\mathrm{qd}_{\mathrm{e}}$, with $\mathrm{q}=0.2$.

At incipient motion, the following conditions need to be fulfilled:

(1) $\bar{\tau}=\rho g R_{b} S_{e}$, the average bed shear stress can be calculated from the flow data

(2) the instantaneous shear stress $\tau_{\max }$ follows from equation (6.4) or (6.5)

Following the calculation procedure described in $\S 2.1$, the following equation for the probability for erosion results:

$$
\mathrm{p}=1-\frac{1}{\sqrt{2 \pi}} \int_{-\sqrt{E_{h}\left(n_{\max }+\frac{1}{s_{u}}\right) \sqrt{\Psi}-\frac{1}{s_{u}}}}^{\left.+\sqrt{E_{n}\left(n_{\max }\right.}+\frac{1}{s_{v}}\right) \sqrt{\Psi}-\frac{1}{s_{u}}} e^{-n^{2} / 2} d n
$$

with $\Psi=$ the flow intensity (equation (2.17)), $\mathrm{n}_{\max }$ the value that determines the definition of incipient motion (see equation (2.7)) and $\mathrm{E}_{\mathrm{h}}=$ the entrainment function, defined as the left hand side of equation (6.5). When $\tau_{c s}$ is known, the probability for erosion for each set of flow parameters can be calculated using tables for the normal distribution. All the terms in equation (6.7) are known.

Mehta et al. (1994) mentioned that flocs at the surface of a soft, cohesive bed can begin to be entrained at flow velocities characterized by the presence of a viscous sublayer that is much thicker than the floc diameter. In this situation the occurrence of turbulence cannot be taken as the reason for the start of erosion. For very soft cohesive beds the above criteria do not represent the complete picture. Also laminar flow conditions need to be considered at incipient motion conditions. Their stochastical variations are not known and hence, not included in this work. However, others (Partheniades 1965, Périgaud 1983) attribute erosion of smooth cohesive sediment beds to the periodical rupture of the laminar sublayer by "turbulent bursts".

$\phi$ and $F_{a}$ are also stochastic variables, which vary spatially and for $F_{a}$ also in time, due to consolidation and other time-dependent processes. Kirchner et al. (1990) have shown the great 
spatial variability of $\phi$ for heterogeneous, cohesionless sediments. The friction angle is strongly dependent on the local bed roughness, which varies along the width and length of the flume. The 10 th and 90 th percentile of their measured friction angles for a single grain on a rough bed spanned an average range of $45^{\circ}$. In fact the variations of $\phi$ along the bed are higher than the difference between the average $\phi$-values for beds of varying roughness.

Partheniades (1965) stated that the changes in cohesion over the bed are much smaller than the variations of the shear stress, and thus the cohesion can be considered a constant. Of course there is an important change in cohesive bonds during consolidation processes, but the time scales for the erosion of a particle and consolidation are very different. For a deposited sediment bed also variations of the shear strength with the depth need to be taken into account. Another important remark concerning the erosion of cohesive soils is made by Mirtskhoulava (1991). The presence of soil surface defects, cracks, cuts and large pores appreciably affects the soil resistance to erosion. Accumulation of defects leads to localized scouring. In this case the spatial variation of 'cohesion' is important. Therefore a homogeneity coefficient $\mathrm{K}$ was introduced:

$\mathrm{K}=1-\frac{\alpha \delta}{\mathrm{C}}$

with $\mathrm{C}=$ the mean value of cohesion, $\delta=$ the standard deviation for the normal distribution of the cohesion and $\alpha=$ coefficient characterizing the probability of minimum resistance of soils (safety coefficient around 2.5).

So to be correct, a joint probability, combining the distributions of the velocity, the cohesion and the angle of repose, has to be evaluated. Especially for sand/mud mixtures where the inhomogeneities in mixture composition and grain size will cause significant variability of the parameters involved. But so far this approach has not been elaborated.

\subsubsection{Summary}

In this paragraph we have found a physical explanation for the variations of the erosion resistance of homogeneous mud/sand mixtures as a function of the \%fines, based on the different structures formed inside the sediment bed. These mechanisms have been visualised in electron microscope 
images. The fine material starts filling the pore spaces in between the sand grains, making the surface smoother. Bit by bit the clay fraction forms bridges, binding the sand grains together, until finally a cohesive network results. The limit between cohesionless and cohesive behaviour has been established as the mixture composition at which the sand grains loose contact with each other and a cohesive structure is formed. Depending on the type of cohesive sediment, the grain size of the sand fraction and the amount of clay particles in the mixture, the critical \%fines is about 10 to $20 \%$ fines by weight or around $5 \%$ fine material by volume, i.e., about the gel point of the fine fraction.

An analysis of all forces acting on a particle, whether cohesive or not, has led to a deterministic equation (6.4) that can be used to calculate the critical shear stress for erosion. Due to the great number of coefficients in the equation, the formula remains a difficult tool to really predict critical shear stresses, when only a limited amount of information on the sediment is available. However, a number of rough calculations have shown, that using some very simple assumptions, the equation provides reliable results and the measured relation between critical shear stress and mixture composition can be reproduced. But, an experimental determination of the erosion threshold seems more suitable when accurate values are required.

Moreover, the processes and parameters involved in incipient motion processes are all variable in time and/or space. Therefore, the problem of erosion threshold needs to be approached stochastically, calculating the probability a certain sediment bed will erode at the given flow conditions (equation (6.7)).

\subsection{Modelling erosion rates of $\mathrm{mud} / \mathrm{sand}$ mixtures}

\subsubsection{Introduction}

The study of our experimental data has shown a good agreement between measured erosion and sediment transport rates and values predicted by existing transport equations for cohesionless as well as cohesive sediments. Furthermore, the above proposed description of the cohesionless or cohesive nature of sand/mud mixtures allows a reliable estimation of the erosion resistance. Therefore, we decided that there is no need to develop a new transport formula for mixtures: the 
existing models and formulas for both cohesionless and cohesive sediments can be applied, provided a good choice of the parameters and coefficients involved is made.

The aim is to elaborate a modelling strategy that can be followed when erosion rates or sediment transport rates of mud/sand mixtures need to be predicted. This strategy will be based on the use of existing formula's and on the knowledge about the behaviour of mud/sand mixtures from this study. The aim is only to describe this strategy and suggest possible ways to handle practical problems. The writing and implementation of the necessary routines to combine both a cohesionless sediment transport model and a cohesive model falls outside the scope of this work. This modelling strategy will be elaborated in the next paragraph.

\subsubsection{Predicting erosion rates and sediment transport}

This paragraph will outline the structure of an overall model to calculate erosion rates and sediment transport of mud/sand mixtures (Figure 6.7). An extensive but qualitative description of the necessary steps in the calculation process will be given without going into the numerical details. Only erosion and sediment transport are discussed; deposition and consolidation are only mentioned briefly.

- The first step is an examination of the mixture composition. From the grain size distribution a calculation of the \%fines (smaller than $63 \mu \mathrm{m}$ ) and the amount of clay (smaller than $2 \mu \mathrm{m}$ ) can be made. Depending on the \%fines and the percentage clay particles and on the average grain size and porosity of the sand fraction, the mixture can be cohesionless or cohesive. The limit between cohesionless and cohesive behaviour lies in between 10 and $20 \%$ fines by weight, according to the results of this study. For very fine sand or a fine fraction containing a significant amount of cohesive clay particles, the limit will be lower. For a coarser mixture, the necessary \%fines to induce cohesion is higher. 


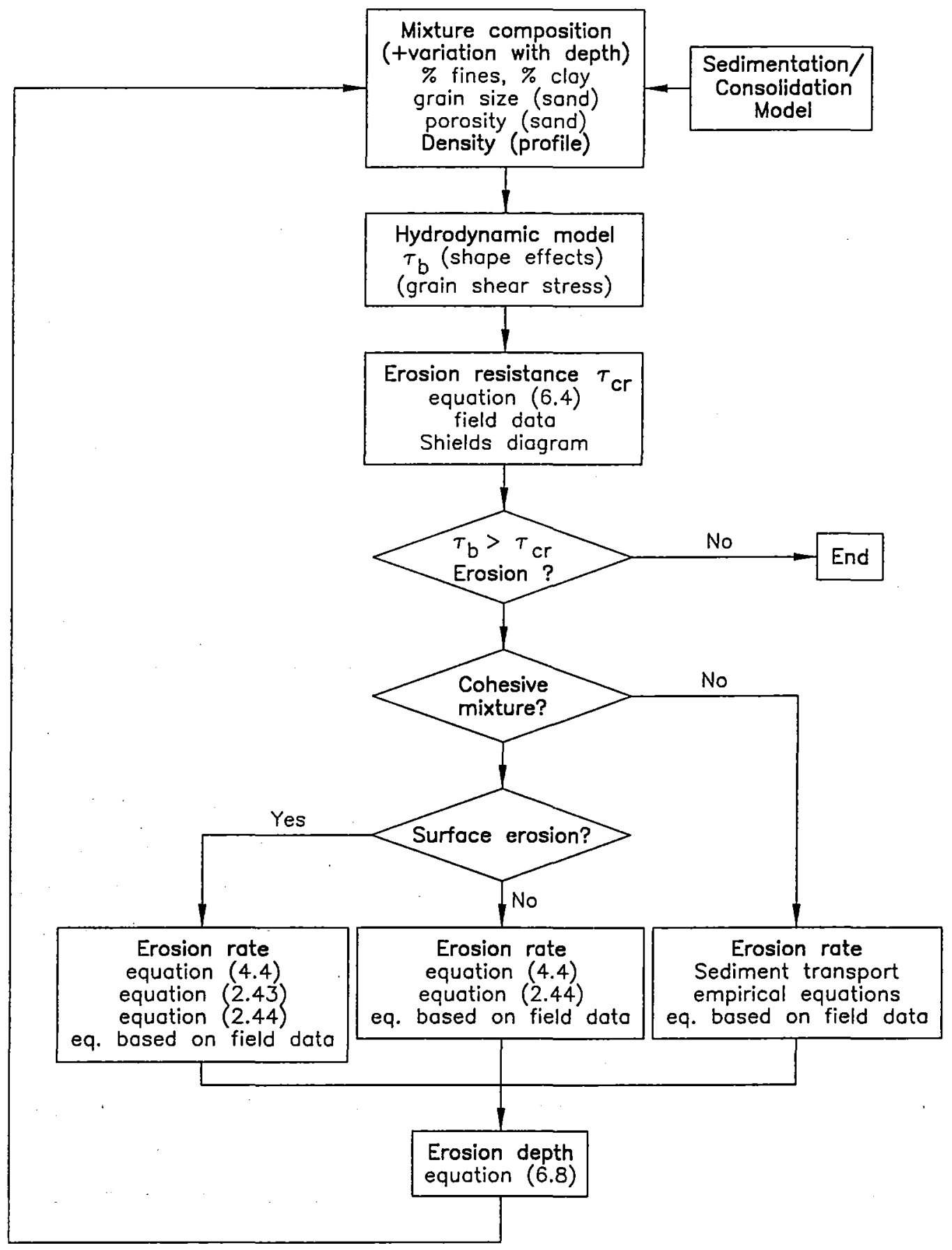

Figure 6.7: Structure of a general model to predict the erosion of mud/sand mixtures. 
Based on the typification of the mixture, a calculation of the erosion resistance can be made. How to calculate the critical shear stress for erosion has been extensively discussed in $\S 6.2$ : the computation can be based either on equation (6.4) or on experimental data for that type of sediment mixture.

- Next a hydrodynamic model has to be used to compute the necessary flow characteristics, among which the bed shear stress is the most important. The calculation of the bed shear stress as a function of the channel geometry is the subject of Chapter 5. For cohesionless sediments bed forms can complicate the calculations, in that case the grain shear stress rather than the bed shear stress is governing the erosion ( $\$ 2.2 .2$ ).

- A comparison between the erosion resistance and the applied bed (or grain) shear stress will indicate if erosion takes place under the given flow conditions. If possible the maximum bed shear stress should be used here, whereas for the transport calculations the average bed shear stress should be applied.

- The experimental study has shown that for cohesionless mixtures, the measured sediment transport rates are similar to the rates for sand only ( $\$ 4.3 .4$ ). A specific equation (4.1) was developed, taking into consideration only data from this study, related to the specific aspects of our flume. However, also existing transport formula e.g., Einstein's bed load equation are in good agreement with measured data. Every sediment transport equation has its own limitations (grain size, flow rates), so depending on the properties of the sediment bed and the flow conditions an appropriate choice of the sediment transport model for cohesionless mixtures can be made. Moreover, most formulas contain some coefficients that need to be computed e.g., based on existing data of sediment transport measurements. The fine fraction will be transported in suspension, hence the transport rate of the fines is directly related to the \%fines in the surface layer.

- When the mixture is cohesive, of course a cohesive erosion model needs to be applied. Depending on bed density and sediment type (among others) the erosion will be surface erosion or mass erosion. For surface erosion equations (2.43) and (2.44) can be used, for mass erosion equation (2.44) can be applied. Most of our data, whether mass erosion or surface erosion, could be represented with equation (4.4). Two coefficients $E_{m}$ and $\alpha$ need to be determined. Table (4.5) gives an overview of the coefficients for the sediment mixtures used in this study: $\alpha \approx 1$ and for $\mathrm{E}_{\mathrm{m}}$ the order of magnitude depends on the bed 
density, sediment type and mode of erosion. Generally, values of $\mathrm{E}_{\mathrm{m}}$ between $10^{-5}$ and $10^{-3}$ are chosen for surface erosion and larger values indicate mass erosion. For mixtures with natural mud the experiments indicate that $E_{\mathrm{m}}$ is of the order of magnitude of $10^{-3} \mathrm{~kg} / \mathrm{sm}^{2}$. Of course the determination of the appropriate coefficients is more accurate when data on the erosion rates are available.

The data of the erosion tests on montmorillonite mixtures have shown the existence of a transition zone in which the erosion did not resemble either cohesionless or cohesive sediment erosion. However, the measured erosion rates for these mixtures were lower than for both cohesionless and cohesive mixtures, therefore, both approaches will give a slight over prediction of the actual erosion, which is on the safe side in case of practical applications.

If the bed properties vary with depth, the model must also include a module that follows the erosion depth. The amount of sediment being eroded follows from the calculated erosion or sediment transport rate, assuming that the erosion is evenly distributed over the sediment bed. Taking into account the bulk density of the surface layer $\left(\rho_{\text {surf }}\right)$, the thickness of the eroded layer $\left(\Delta z_{e}\right)$ for each time step $\Delta t$ can be computed from the erosion rate (E) as follows:

$$
\Delta z_{e}=\frac{E \Delta t}{\rho_{\text {surf }}}
$$

This depth of erosion then needs to be compared with the density profile and the profile of mixture composition of the bed, to establish the instantaneous properties of the new surface layer. At that time the next step in the calculations is again the evaluation of the sediment properties.

Due to variations of the sediment properties with depth different formulas might need to be used, e.g., due to presence of a sand layer, but also the coefficients may change, e.g., from surface erosion at low density to mass erosion at higher densities. These variations can also result in a complete stop of the erosion. However, the experiments indicated that for a wide range of mixture compositions and a narrow variation of bed density the erosion rates of cohesive mixtures all could be represented by a single relation, i.e., a single set of coefficients. For instance, the erosion of the kaolinite mixtures containing 
between 5 and $15 \%$ fines and having a bulk density between 1.6 and $1.9 \mathrm{~kg} / \mathrm{dm}^{3}$ can all be represented using equation (4.5).

If no measurements exist of density profiles, the evolution of density with depth can be estimated from the following equation proposed by Mehta et al. (1975):

$$
\frac{\rho_{d}}{\bar{\rho}_{d}}=\zeta\left(\frac{z}{H}\right)^{-\xi}
$$

with $\rho_{d}$ the dry density at depth $z$ below the surface non-dimensionalised by the average dry density of the deposit, $\mathrm{H}$ is the total thickness of the sediment deposit and $\zeta$ and $\xi$ are sediment related coefficients that need to be determined, $\zeta$ is about 0.7 and $\xi$ is approximately 0.3 for natural estuarine muds. If the suspension concentration and composition of the initial suspension are known a numerical sedimentation/consolidation model can be used to predict the evolution of the resulting density profile of the deposit in time. Toorman (1992) developed a sedimentation/consolidation model that includes mud/sand mixtures. However, a major problem with consolidation models is the lack of general constitutive equations for permeability (or equivalent stress-free filtration rate, Toorman 1995) and effective stress, which are unknown for pure cohesive sediment. The problem is even more complex for mixtures.

How the mixture composition varies with depth has not been studied in detail in our experiments but the encountered mode of erosion (suspension or bed load) showed that sand collected in a layer at the bottom. Furthermore the shape of the density profile (smooth or stepped) gives an indication of the distribution of sand in each layer. Similarly results by Ockenden et al. (1988) indicate that if segregation takes place, the top few $\mathrm{mm}$ are sand-free and most of the sand accumulates in the bottom layer. In between the sand content varies gradually.

Remarks: 1. For narrow flumes the shear stress distribution over the cross section can be introduced (Chapter 5) and hence different erosion rates along the width of the cross section can be calculated. This leads to a more detailed erosion pattern. 
2. This modelling strategy has been followed by Dauwe et al. (1995) for the simulation of the erosion rates for layered sediment beds ( $\$ 4.4 .4)$.

3. The possibilities of developing a unified erosion theory for the whole range of mixture compositions have been explored. E.g., the probabilistic approaches of the transport formulas developed by Einstein for cohesionless sediments (Einstein 1982 and Berlamont 1981, § 2.2.2) and by Partheniades (1965, § 2.3.2) for cohesive sediments are very similar and can be combined into 1 general equation. However, depending on the mixture composition the new equation will reduce to either a cohesionless or a cohesive formula.

\subsection{Summary and conclusions}

\subsubsection{Necessary information to model the erosion of mud/sand mixtures}

Using the information presented in this chapter and the results of the experimental work, we are able to answer the following questions:

1. Which information (related to the flow field and the sediment bottom) is needed to predict the erosion of mud/sand mixtures in uniform flow conditions?

2. How can this information be obtained: from measurements in the laboratory or in the field, from calculations or are there parameters that need to be estimated?

\section{A. Flow parameters}

The most important parameter that controls erosion and sediment transport is the bed shear stress. In Chapter 5 it was stated that the bed shear stress depends on the flow conditions and on the geometry of the flow. The bed shear stress can be calculated from a measured (centre-line) velocity profile or from the water depth, average velocity (discharge) and slope of the energy line by means of a side wall elimination technique. However, for narrow flumes this method overestimates the average bed shear stress. The relation between mean bed shear stress, 
maximum bed shear stress and bed shear stress calculated by side wall elimination depends on the shape of flume cross section.

\section{B. Sediment properties}

Three aspects of the sediment bed are very important with respect to the erosion of the bed: the mixture composition, the density of the bed and the stratification of the bed. The mixture composition, especially the amount of fines and the amount of clay, will determine whether the sediment behaves as a cohesionless or a cohesive sediment. An analysis of our experiments and experimental data from literature has indicated that the limit between cohesionless and cohesive behaviour lies around 10 to $20 \%$ fines. To determine the fine fraction, wet sieving of a sample on a $63 \mu \mathrm{m}$ sieve is sufficient. The type of cohesive sediment in the mixture, its mineralogical composition, the organic content, the presence of biological organisms, etc. play also an important role. A limited number of laboratory experiments measuring erosion resistance and erosion rates, together with an observation of the mode of erosion will be very helpful to accurately predict future erosion events. Especially since our experiments have shown that for \%fines smaller than $25 \%$, a quite linear relation exists between erosion resistance and \%fines and that the erosion rates of all mixtures relate in a similar way to the excess shear stress, both for cohesionless and cohesive mixtures. Variations of mixture compositions with depth have an influence on both erosion resistance and erosion rates. To get an idea of the stratification of the bed, core samples need to be taken carefully and examined over depth. So far, it is not possible to predict the actual variation of sediment properties with depth by means of the existing sedimentation/consolidation models.

The bed density will give some indication of the mode of erosion of cohesive mixtures. For soft beds, bulk density smaller than $\pm 1500 \mathrm{~kg} / \mathrm{m}^{3}$, surface erosion is likely to take place, for higher bed densities the erosion is mostly mass erosion. Variations of density with depth due to settling and consolidation processes will have an important effect on the erosion resistance of the bed. Also the mode of erosion might change, but only for very strong density gradients, e.g., between type $C$ and type $A$ sediments in a combined sewer. If the surface density is known, an empirical equation like Mehta's formula (equation (6.9)) can be used to estimate the density gradients with 
depth. If data on the initial suspension concentration and composition are available, sedimentation/consolidation models allow much better prediction of density profiles, provided the constitutive equations for permeability and effective stress are known. Toorman's model (Toorman 1992) allows in principle also a rough estimation of the sand/mud content within the profile. To get more accurate information, a core box sample can be analysed or using a densimeter a density profile can be measured.

\subsubsection{Conclusions}

Modelling the erosion of sand/mud mixtures is possible using existing transport formulas. The erosion process consists in fact of two aspects: erosion resistance and erosion rates. The erosion resistance of mud/sand mixtures has been physically explained in terms of the amount of fines in the mixture. This analysis has led to the definition of a critical amount of fines, between 10 and $20 \%$ by weight, above which the cohesive forces dominate and the sediment is in fact a cohesive sediment and can be modelled using existing equations for cohesive sediments. Below this critical content of fines, the mixture can be treated as a cohesionless sediment. The critical shear stress can be predicted with reasonable accuracy with the proposed equation (6.4), which reduces, depending on the mixture composition, to the equation for uniform cohesionless or cohesive sediments. However, the formula contains a lot of coefficients, some of which are difficult to evaluate. Therefore, an experimental determination of the erosion resistance might be useful.

A modelling strategy has been developed, based on which erosion and sediment transport rates can be calculated using existing transport formulas. Special attention has to be paid to the calculation of the bed shear stress, e.g., in the case of application to a sewer system, where the narrowness and shape of the cross section have an important influence on the computations. Some practical guidelines on how to calculate the average and maximum bed shear stress from a measured velocity profile or from average flow date have been presented in Chapter 5 for rectangular and circular cross sections. 


\section{Chapter 7: Conclusions and recommendations}

\subsection{Summary and conclusions}

\subsubsection{Summary}

The sediments found in tidal rivers, estuaries and coastal zones are often mixtures of sand and mud. The accumulation and movement of these sediments need to be understood since they have a large impact on the accessibility of harbours and on the required maintenance dredging operations. The ability of the mud to adsorb large amounts of contaminants increases the necessity to fully understand its behaviour. The sediment bed found in a combined sewer system can also be described as a mixture of cohesive (or cohesive-like) and cohesionless sediments. Here, the accumulation of sediments reduces the hydraulic capacity and the erosion of the sediment bed can cause environmental problems when the flow is directly discharged into a natural water course. Again, it is important that the behaviour of the sediment mixture is properly understood.

In this thesis the erosion of mud/sand mixtures in uniform flow conditions has been studied experimentally. The aim was to examine the effect of the mixture composition, expressed as the sand content or \%fines, on the behaviour of the sediment in uniform flow. As a point of reference for the research on mixture behaviour, the current knowledge on the erosion of sand and the erosion of cohesive sediments was reviewed.

The experimental work, carried out in a straight rectangular flume, consisted of two major parts. First, the transition from cohesionless to cohesive behaviour, with respect to erosion resistance and mode of erosion in uniform flow, was studied by adding more and more cohesive sediment to sand. The cohesive materials used were two types of clay and natural mud from the river Scheldt. The impact of other parameters such as bed density and consolidation time has been examined as well. 
The second part of the experimental work dealt with naturally deposited sediment beds. Using a settling tank mounted on top of the measuring section of the flume and a transparent settling column, the formation of a layered bed from a mud/sand suspension was followed. The erosion in uniform flow of the stratified deposit was evaluated as a function of the mixture composition of the initial suspension.

The bed shear stress is one of the most important parameters in sediment transport processes: the maximum bed shear stress will determine the moment of incipient motion, while the average bed shear stress is an input for the calculation of sediment transport. The shape of the bed shear stress distribution influences the development of bed forms or other erosion patterns. In order to apply the knowledge gained from experiments in a narrow rectangular flume to field conditions, i.e., sewers, rivers or wide estuaries, the effects of the shape and the scale of the flume cross section on bed shear stress distributions were studied in more detail. Our experimental results have been compared to data from similar laboratory experiments in a flume with a semi-circular cross section and with field data from the river Scheldt and the major collector sewer of Brussels.

Finally, based on the experimental results, the erosional behaviour of mud/sand mixtures was explained in terms of the different structures formed inside the bed. Depending on the mixture composition, a mixture can be treated as either cohesionless or cohesive, and some guidelines to model the erosion resistance and erosion rates of these mixtures have been formulated.

\subsubsection{General conclusions}

With respect to the erosion resistance of homogeneous mud/sand mixtures the experimental research has led to the following conclusions. In general, the erosion resistance increases with increasing content of fines. The fines fill the pore spaces in between the sand grains and make the mixture smoother and thus more difficult to erode. At some spots in the mixture the fines create bridges connecting the sand grains. With increasing \% fines these bridges, originally only some threads made up of loose flocs, become stronger and stronger bonds and eventually a cohesive network is formed in the sediment bed.

A critical amount of fines exists at which the sand grains loose contact and a mud matrix covers the sand particles. This critical content of fines was found to be between 10 and $20 \%$ fines by 
weight or around $5 \%$ fines in volumetric concentrations and is a function of the sand grain size, the type of cohesive material, the clay fraction and the organic content. Below this limit, the mixture can be treated as a cohesionless sediment: friction and gravity are the forces opposing particle motion. Above the critical content of fines cohesive forces determine the behaviour of the mixture: the erosion resistance is governed by the electrochemical bonds in the sediment. Biological activity and the presence of organic matter may result in additional complex bindings. The erosion resistance also increases with increasing bed density or consolidation time.

Based on the analysis of the different forces acting on the sediment bed, an equation to calculate the erosion resistance of a mud/sand mixture has been developed. This equation contains many unknown coefficients and its applicability depends on the available (field) data. However, using some simple assumptions, very reasonable results can be obtained.

To model erosion and sediment transport rates of homogeneous mud/sand mixtures, the existing formulas for both cohesionless and cohesive sediments can be applied, since a mixture can be seen as either cohesionless or cohesive for an amount of fines below or above the critical limit. The experiments have shown that the erosion of the cohesionless mixtures resembles sand transport processes with the formation of ripples and dunes. The sediment transport can be represented using existing sand transport formulas. For the cohesive mixtures, the erosion process can be described as mass or surface erosion, depending on the type of cohesive sediment and the bed density.

For a sediment bed formed out of a mud/sand suspension, the following conclusions can be drawn from this study. The deposit will be highly stratified, i.e., both density and mixture composition will vary within the bed. Sand segregation occurs during the deposition process, when the initial mud concentration is below the gel point or the settling rates are high. Otherwise, a structure is formed in the mud matrix, which traps part of the sand. An increasing sand content enhances the consolidation and results in higher bed densities and smaller layer thicknesses. However, these processes appear to be limited to a maximum sand content above which no additional effects are found. 
The erosion resistance is related to the bed structure, which in turn is a function of the sand content and the properties of the mud. The erosion of a layered bed is a sequence of suspended load phases, during the erosion of a muddy layer, and bed load transport, when a segregated sand layer is reached. Depending on the initial suspension composition both modes can be equally important and they both need to be taken into account when modelling the erosion processes.

A comparison of the results of similar erosion tests in flumes with a rectangular and a semicircular cross section revealed important differences in erosional behaviour. These shape effects are caused by the secondary flow structure, which affects the bed shear stress distribution. Detailed measurements of the velocity distributions in both flumes have demonstrated that the secondary currents are much more important in a circular cross section and cause much more erosion. The bed shear stress distribution in the rectangular flume is fairly uniform with a maximum value along the centre line. In the semi-circular cross section more extreme values can exist, and usually an important local maximum near the side walls is found.

Furthermore, it was shown that the frequently used side wall elimination calculations overestimate the average bed shear stress for narrow flumes and that these methods calculate in fact the maximum bed shear stress. Both the scale and the shape effects are important when the experimental findings are to be applied to field conditions, e.g. wide rivers, estuaries or sewer pipes.

A numerical model to predict the erosion of mud/sand mixtures, whether homogeneous or stratified, can be built up of existing models for sand and mud erosion. However, some extra steps have to be added. First of all, the mixture composition and its variation within the bed as well as the bed density profile need to be known (or calculated). Based on the composition of the surface layer, one can decide whether this layer is cohesive or not. Secondly, a procedure to calculate the erosion resistance of the mud/sand mixture has to be included. If the applied bed shear stress exceeds the shear strength the erosion rate can be calculated using a mud or a sand equation. Following a calculation of the erosion depth at each time step, the new surface density and composition needs to be evaluated and this evaluation can lead not only to a changed erosion resistance but possibly also to a modified mode of erosion and transport. 
A last conclusion related to this experimental study is that even with a simple, straight rectangular flume, using simple measuring-techniques, valuable results can be obtained.

\subsection{Recommendations for future research}

In order to understand the behaviour of the whole range of possible mud/sand mixtures, erosion experiments starting from pure mud and adding more and more sand, at constant bed density, should be carried out to check if a maximum erosion resistance really exists and to verify the increasing erosion resistance for decreasing clay contents as reported in literature.

The experiments on layered beds described in this work also cover just a limited range of mixture compositions. This range needs to be extended in order to understand fully the bed formation processes of layered mud/sand deposits and the resulting variation of the mixture composition in the bed. Especially the existence of a critical sand content, at which maximum segregation and a maximum consolidation rate is reached, needs to be examined further.

The present study has been limited to uniform flow conditions. In the field, however, the flow conditions can be very unsteady. The time-dependency of the flow parameters, e.g. the bed shear stress, has a severe impact on the sediment transport rates, as was already demonstrated by Kabir (1993) for cohesionless sediments. In estuaries the tidal waves determine the motion of the sediment and the effect of waves on the movement of mud/sand mixtures has not yet been investigated. In sewers the flow is gradually varying in dry weather conditions but becomes very unsteady during a storm event. A new F.K.F.O.-project starting in January 1996 will be dedicated to the erosion of mixed sediments in unsteady flow; the laboratory experiments in Gent and Leuven will be continued in unsteady flow conditions.

Another aspect that is still far from being understood are biological processes. Organic matter and micro-organisms can have all sorts of effects on the erodibility of sediments. In a proposed continuation of the MAST-project (COSINUS, Integrated NUmerical Simulation models for the prediction of COhesive Sediment transport and bed morphodynamics in estuaries and coastal 
zones) these aspects will be studied for the estuarine environment. The study of the influence of bed texture and sediment composition on the erosion properties is also included in the objectives of that research.

In the field of sewer sediments a European research project has been submitted to the EC. The SEWERS-project (Solids Emissions from Waste watER Systems: Abatement of pollution) will attempt to study the deposition, erosion, release and transport of sediments and associated pollutants in sewers, and to overflows and outfalls. One of the aspects is the behaviour of sediment mixtures in unsteady flow, which will be investigated by means of laboratory as well as field experiments.

Finally, mixtures of cohesive and non cohesive sediments can be found both in river or estuary systems and in combined sewers. Up to now, there has not been much collaboration between these disciplines. However, our study showed that the erosion processes are very similar and that much can be gained from a collaboration. 


\section{Bibliography}

1. ACKERS P. "Sediment aspects of drainage and outfall design", Environmental Hydraulics, Lee \& Cheung eds, 1991.

2. ALVAREZ-HERNANDEZ $\mathbf{E}$. "The influence of cohesion on sediment movement in channels of circular cross-section", PhD thesis, University of Newcastle Upon Tyne, U.K., 1990.

3. AMOS C.L. AND MOSHER D.C. "Erosion and deposition of fine-grained sediments from the Bay of Fundy", Sedimentology, 1985, pp. 815-832.

4. AMOS C.L., DABORN G.R. CHRISTIAN H.A., ATKINSON A. AND ROBERTSON

A. "In situ erosion measurements on fine-grained sediments from the Bay of Fundy", Marine Geology, 108, 1992, pp. 175-196.

5. AMOS C.L., SUTHERLAND T.F. AND ZEVENHUIZEN J. "The stability of finegrained sediments in Manitounik Sound, Hudson Bay, Canada", submitted to Sedimentology, July 1994.

6. ARIATHURAI R. AND ARULANANDAN K. "Erosion rates of cohesive soils", ASCE, Journal of the Hydraulics Division, February 1978, pp. 279-283.

7. ARMANINI A. AND DI SILVIO G. "A one-dimensional model for the transport of a sediment mixture in non-equilibrium conditions", IAHR, Journal of Hydraulic Research, Vol. 26, No. 3, 1988.

8. ARULANANDAN K. "Fundamental aspects of erosion of cohesive soils", ASCE, Journal of the Hydraulics Division, May 1975, pp. 635-639.

9. ASHLEY R.M. AND BERTRAND-KRAJEWSKI J.-L. "Sewer sediment origins and transport in small catchments", 6th International Conference on Urban Storm Drainage, September 12-17, 1993, Niagara Falls, Ontario, Canada.

10. ASHLEY R.M. AND CRABTREE R.W. "Sediment origins, deposition and build-up in combined sewer systems", Water Science \& Technology, Vol. 25, No. 8, 1992. 
11. ASHLEY R.M., ARTHUR S., MCGREGOR I. AND COGHLAN B.P. "Fluid sediment movement and first flush in combined sewers", 6th International Conference on Urban Storm Drainage, September 12-17, 1993, Niagara Falls, Ontario, Canada.

12. ASHLEY R.M., LONGAIR I.M., WOTHERSPOON D.J.J. AND KIRBY K. "Flow and sediment movement monitoring in large sewers", 6th International Conference on Urban Storm Drainage, September 12-17, 1993, Niagara Falls, Ontario, Canada.

13. ASHLEY R.M., LONGAIR I.M., WOTHERSPOON D.J.J., WILLIAMS J.A. AND WILLIAMS R. "The Movement of Sediment in Combined Sewers", SERC Grant No. GR/E76308, Final Report, April 1992.

14. ASHLEY R.M., WOTHERSPOON D.J.J., COGHLAN B.P. AND RISTENPART E. "Cohesive sediment erosion in combined sewers", 6th International Conference on Urban Storm Drainage, September 12-17, 1993, Niagara Falls, Ontario, Canada.

15. ASHLEY R.M., WOTHERSPOON D.J.J., GOODISON M.J., MCGREGOR I. AND COGHLAN B.P. "The deposition and erosion of sediments in sewers", Water Science \& Technology, Vol. 26, No. 5-6, pp. 1283-1293, 1992.

16. ASHLEY R.M., WOTHERSPOON D.J.J., MCGREGOR I. AND COGHLAN B.P. "The erosion and movement of sediments and associated pollutants in combined sewers", Water Science \& Technology, Vol. 25, No. 8, 1992.

17. BASTIN A. " Regionale sedimentologie en morfologie van de zuidelijke Noordzee en van het Schelde estuarium" PhD thesis, Katholieke Universiteit Leuven, 1974 (in Dutch).

18. BERLAMONT J. "Waterloop- en Waterbouwkunde (cursustekst Waterwegen)", Wouters boekhandel, 1981 (in Dutch).

19. BERLAMONT J., OCKENDEN M., TOORMAN E. AND WINTERWERP J. "The characterisation of cohesive sediment properties", Coastal Engineering, 21, 1993, pp. 105-128, Elsevier Science Publishers B.V., Amsterdam.

20. BERTRAND-KRAJEWSKI J.L., BRIAT P. AND SCRIVENER O. "Sewer sediment production and transport modelling: A literature review", Journal of Hydraulic Research, Vol. 31, 1993, No. 4, pp. 435-460.

21. BESTUUR GEOTECHNIEK Rapporten 7508-77/150 (betreffende de boringen), 7508$77 / 152$ (labo onderzoek), 7508-78/212 (Zuid-Oostdam) en 7508-79/1 (LNG\&Oostdam) 1977, 1978, 1979 (in Dutch). 
22. BOOIJ R. "Measurements of the flow field in a rotating annular flume", Communications on hydraulic and geotechnical engineering, T.U. Delft, October 1994.

23. CHESHER T.J. AND OCKENDEN M.C. "Numerical modelling of mud and sand mixtures" 4th Nearshore and Estuarine Cohesive Sediment Transport Conference INTERCOH'94, 11-15 July 1994, Wallingford, U.K.

24. CHRISTENSEN B.A. "Incipient motion on cohesionless channel banks", in Sedimentation Symposium to honor Professor H.A. Einstein, ed. H.W. Shen, 1972, Colorado State University.

25. CHRISTENSEN B.A. discussion of "Erosion and deposition of cohesive soils", by E. Partheniades, ASCE, Journal of the Hydraulics Division, September 1965, pp. $301-308$.

26. CIRIA "Sediment movement in combined sewerage and storm-water drainage systems", Project Report 1, 1987.

27. COLLINS M. "The behaviour of cohesive and non-cohesive sediments", Proceedings of the 17th International seminar on the environmental aspects of dredging activities, 27 November-1 December 1989, Nantes.

28. DADE W.B. AND NOWELL A.R.M. "Moving muds in the marine environment", Proceedings of the ASCE Specialty Conference on Coastal Sediments, Seattle 1991, pp. 54-71.

29. DADE W.B., NOWELL A.R.M. AND JUMARS P.A. "Predicting erosion resistance of muds", Marine Geology, 105, pp. 285-297, 1992.

30. DAUWE W. AND MAEGHE K. "Berekening van het zwevend sedimenttransport langs de Belgische kust" M.Eng. thesis, Departement Burgerlijke Bouwkunde, Katholieke Universiteit Leuven, 1995 (in Dutch).

31. DVWK "Sediment transport in open channels-Calculation procedures for the engineering practice", Bulletin 17, Verlag Paul Parey, Hamburg/Berlin 1990.

32. DYER K.R. "Sediment processes in estuaries: Future research requirements", Journal of Geophysical Research, Vol. 94, No. C10, pp. 14327-14339, October 1989.

33. EDGE M.J. AND SILLS G.C. "The development of layered sediment beds in the laboratory as an illustration of possible field processes", Quarterly Journal of Engineering Geology, London 1989, Vol. 22, pp. 271-279. 
34. EINSELE G., OVERBECK R., SCHWARZ H. AND UNSÖLD G. "Mass physical properties, sliding and erodibility of experimentaly deposited and differently consolidated clayey muds", Sedimentology 21, pp. 339-372, 1974.

35. EINSTEIN H.A. "Formulas for the transport of bed load", Reprinted from ASCE Transactions, Vol. 107, 1942, Paper No. 2140, in Classic papers in Hydraulics, ASCE, 1982.

36. F.K.F.O.-PROJECT NR 2.9012.90 "Erosion, sedimentation and resuspension of partly cohesive, partly non cohesive sediments, in particular in unsteady flow" Annual reports $1990,1991,1992,1993 \& 1994$.

37. FRENCH R.H. "Open-channel hydraulics" 1985, McGraw-Hill Inc.

38. GOVERS G. "Initiation of motion in overland flow", Sedimentology, 1987, Vol. 34, pp. $1157-1164$

39. GOVERS G. "Evaluation of transporting capacity for overland flow", in: Overland flow hydraulics and erosion mechanics. Paersons A.J. and Abrahams A.D. editors, UCL Press London, 1992.

40. GOVERS G. "Effects of initial water content and soil mechanical strength on the runoff erosion resistance of clay soils" Aust. Journal Soil Res., 1993, Vol. 31, pp. 549-566.

41. GRISSINGER E.H., ASMUSSEN L.E. AND ESPEY W.H. "Channel stability in undisturbed cohesive soils", ASCE, Journal of the Hydraulics Division, november 1963, pp. 259-264.

42. GULARTE R.C.., KELLY W.E. AND NACCI V.A. "Rheological methods for predicting cohesive erosion", 1979.

43. GUST G. AND MORRIS M.J. "Erosion thresholds and entrainment rates of undisturbed in situ sediments" Journal of Coastal Research, Special Issue No. 5, 1989, pp. 87-99.

44. HAMM L., HUYNH-THANH S. AND TEMPERVILLE A. "Simulation of cohesive sediment flume erosion test by a current with a stratified turbulent transport model", SOGREAH 52147 R6, Part of MAST G6M, October 1992.

45. HOUWING E.J. AND VAN RIJN L.C. "In situ determination of the critical bed shear stress for erosion of cohesive sediments" Proceedings of the 24th International Conference on Coastal Engineering, Kobe, October 1994. 
46. HUYGENS M. AND TITO L. "Sediment transport of mixtures of cohesive and noncohesive materials in sewer conduits" Hydrosoft, 1994.

47. HUYGENS M., TITO L. AND VERHOEVEN R. "Study on the transport of cohesive and non-cohesive sediments in a circular flume", Annual report on the state of the experiments, 1992, 1993 \& 1994.

48. HUYSENTRUYT H. "Experiments on the consolidation of natural mud. Effect of composition, mixtures with sand and layering" 4th Nearshore and Estuarine Cohesive Sediment Transport Conference INTERCOH'94, 11-15 July 1994, Wallingford, U.K. (Poster session)

49. HYDRAULICS RESEARCH STATION WALLINGFORD "River Scheldt Surge Barrier: Study of estuary sediments", Report No. EX 928, November 1980.

50. HYDRAULICS RESEARCH STATION WALLINGFORD "Sediment transport in sewers", Report No. IT 222, February 1982.

51. HYDRAULICS RESEARCH WALLINGFORD "Estuarine Muds Manual", Report No. SR 164, february 1988.

52. JAMES P.W. AND JONES T.E.R. "The measurement and prediction of surface shear stress induced by newtonian and non-newtonian fluids", Theoretical an Applied Rheology, Proc. Int. Congr. on Rheology, Brussels, Belgium, August 1992, ed. P. Moldenaers et al.

53. JONES T.E.R. "A review of rheometric methods for use with fine sediments" 4th Nearshore and Estuarine Cohesive Sediment Transport Conference INTERCOH'94, 11-15 July 1994, Wallingford, U.K.

54. JULIEN P.Y. AND LAN Y. "Rheology of hyperconcentrations", ASCE, Journal of Hydraulic Engineering, march 1991, pp. 346-353.

55. JULIEN P.Y., LAN Y. AND BERTHAULT G. "Experiments on stratification of heterogeneous sand mixtures", Bull. Soc. Géol. France, 1993, no. 5, pp 649-660.

56. KABIR M.R. "Bed load transport in unsteady flow", $\mathrm{PhD}$ thesis, K.U. Leuven, january 1993.

57. KABIR M.R. AND TORFS H. "Sediment transport measurements on the river Scheldt at Temse" Internal report of the measuring-campaign on May 13, 1991. 
58. KABIR M.R. AND TORFS H. "Comparison of different methods to calculate bed shear stress", IAWPRC Water Science and Technology, Vol. 25, No. 8, pp. 131-140, 1992.

59. KAMPHUIS J.W. "Influence of sand or gravel on the erosion of cohesive sediment", IAHR, Journal of Hydraulic Research, 1990, No. 1.

60. KAMPHUIS W. AND HALL K.R. "Cohesive material erosion by unidirectional current", ASCE, Journal of Hydraulic Engineering, January 1983, pp. 49-61.

61. KIRBY J.M. "Rheological characteristics of sewage sludge: a granuloviscous material" Rheologica Acta, Vol. 27, 1988, pp. 326-334.

62. KIRCHNER J.W., DIETRICH W.E., ISEYA F. AND IKEDA H. "The variability of critical shear stress, friction angle, and grain protrusion in water-worked sediments", Sedimentology, Vol. 37, 1990, pp. 647-672.

63. KIRKGÖZ M.S. "Turbulent velocity profiles for smooth and rough open channel flow", ASCE, Journal of Hydraulic Engineering, Vol. 115, November 1989.

64. KLEIJWEGT R.A. "On sediment transport in circular sewers with non-cohesive deposits", PhD thesis T.U.Delft, 1992.

65. KLEIJWEGT R.A., VELDKAMP R.G. AND NALLURI C. "Sediment in sewers: Initiation of transport", IAWPRC, Water Science \& Technology, Vol. 22, No. 10/11, 1990, pp. 239-246.

66. KNIGHT D. W. AND MACDONALD J.A. "Open channel flow with varying bed roughness" ASCE, Journal of the Hydraulics Division, Vol. 105, No. HY9, 1979, pp. 1167-1183.

67. KNIGHT D.W., DEMETRIOU J.D. AND HAMED M.E. "Boundary shear in smooth rectangular channels" ASCE, Journal of Hydraulic Engineering, Vol. 110, No. 4, 1984, pp. 405-422.

68. KRISHNA-SARMA A. "Velocity, shear and friction factor studies in subcritical rough turbulent open channel flows", PhD thesis, Department of Civil Engineering, Indian Institute of Science, Bangalore, September 1993.

69. KRONE R.B. "Advances in knowledge of fine sediment processes in estuaries", ISRS Conference, 31 march, 1986.

70. KRONE R.B. "Engineering interest in the benthic boundary layer", The Benthic Boundary Layer, McCave ed., Plenum Press, 1976. 
71. KRONE R.B. "Flume studies of the transport of sediment in estuarial shoaling processes", Final report, June 1962, University of California, Berkeley.

72. KUSUDA T., UMITA T. AND AWAYA Y. "Erosional process of fine cohesive sediments", Memoirs of the Faculty of Engineering, Kyushu University, December 1982.

73. KUTI O.K. AND YEN C.L. "Scouring of cohesive soils" IAHR, Journal of Hydraulic Research, Vol. 14, No. 3, 1976, pp. 195-206.

74. KUYPER C., CORNELISSE J. AND WINTERWERP J. "The deposition of graded cohesive sediments", presented at the International Symposium on Sediment Transport Modeling, New Orleans, August 1989.

75. LABORATORIUM VOOR HYDRAULICA, K.U.L. "Verslag van de proeven uitgevoerd op slib van Zeebrugge met het oog op de realisatie van een slibgemaal" in opdracht van S.B.B.M., 1983 (in Dutch).

76. LAU Y.L. AND KRISHNAPPAN B.G. "Does reentrainment occur during cohesive sediment settling ?", ASCE, Journal of Hydraulic Engineering, Vol. 120, February 1994, pp. 236-244.

77. LAVELLE J.W., MOFJELD H.O. AND BAKER E.T. "An in situ erosion rate for finegrained marine sediment" Journal of Geophysical Research, Vol. 89, No. C4, 1984, pp. 6543-6552.

78. MARK O. "A sediment transport model for sewers", First International Workshop on Sewer Sediments, 4-6 september 1991, Brussels.

79. MARK O., APPELGREN C. AND LARSEN T. "Principles and approaches for numerical modelling of sediment transport in sewers", 1994.

80. MAST G6M COASTAL MORPHODYNAMICS "On the methodology and accuracy of measuring physico-chemical properties to characterize Cohesive Sediments", prepared as part of the EC MAST-I research programme, July 1993.

81. MCCAVE I.N. "Erosion, transport and deposition of fine-grained marine sediments", Geol. Soc. London, Spec. Publ. No. 15, 1984.

82. MCQUIVEY R.S. AND RICHARDSON E.V. "Some turbulence measurements in openchannel flow", ASCE, Journal of the Hydraulics Division, Vol. 95, January 1969. 
83. MEHTA A.J. "Laboratory studies on cohesive sediment deposition and erosion", Physical Processes in Estuaries, 1988, Job Dronkers, Wim Van Leussen eds., Springer-Verlag.

84. MEHTA A.J. "On estuarine cohesive sediment suspension behaviour", Journal of Geophysical Research, Vol. 94, No. C10, pp. 14303-14314, October 1989.

85. MEHTA A.J. "Review notes on cohesive sediment erosion", ASCE, Coastal Sediments, Volume I, Nicolas C. Krauss et al. ed., pp. 40-53, 1991

86. MEHTA A.J. AND CHRISTENSEN B.A. "Initiation of sand transport over coarse beds in tidal entrances", Coastal Engineering, No. 7, 1983, pp. 61-75.

87. MEHTA A.J. AND DYER K.R. "Cohesive sediment transport in estuarine and coastal waters", The Sea, Ocean Engineering Science, Volume 9, Part B, 1990, John Wiley Interscience, pp. 815-839.

88. MEHTA A.J. AND LEE S.-C. "Problems in linking the treshold condition for the transport of cohesionless and cohesive sediment grains", Journal of Coastal Research, 10(1), 1994, pp. 170-177.

89. MEHTA A.J. AND PARTHENIADES E. "Kaolinite resuspension properties", IAHR, Journal of Hydraulic Research, Vol. 13, No. 4, 1975, pp. 361-381.

90. MEHTA A.J., HAYTER E., PARKER R., KRONE R.B. AND TEETER A. "Cohesive sediment transport, I: Process description \& II: Application", ASCE, Journal of Hydraulic Engineering, August 1989, pp. 1076-1093.

91. MEHTA A.J., PARTHENIADES E., DIXIT J.G. AND MCANALLY W.H. "Properties of deposited kaolinite in a long flume", Applying Research to Hydraulic Practice, Mississippi, Jackson, August 17-20, 1982.

92. MIGNiOT C. "Manuel sur l'hydrodynamique sédimentaire et l'érosion et sédimentation du littoral", Cours enseigné à la faculté des sciences d'Orsay, Paris.

93. MIRTSKHOULAVA TS.E. "Scouring by flowing water of cohesive and non cohesive beds", IAHR, Journal of Hydraulic Research, No. 3, 1991, pp. 341-354.

94. MISRI R.L., GARDE R.J. AND RANGA RAJU K.G. "Bed load transport of coarse nonuniform sediment", ASCE, Journal of Hydraulic Engineering, Vol. 110, March 1984.

95. MORSE B. AND TOWNSEND R.D. "Modeling mixed sediment suspended load profiles", ASCE, Journal of Hydraulic Engineering, Vol. 115, June 1989. 
96. MURRAY W.A. "Erosion of coarse sand-clayey silt mixtures", ASCE, Journal of Hydraulics Division, October 1977, pp. 1222-1227.

97. NALLURI C. AND EL-ZAEMEY A.K.S. "Sediment transport over deposited beds in sewers", 6th International Conference on Urban Storm Drainage, Niagara Falls, Ontario, Canada, september 12-17, 1993.

98. NALLURI C. AND GHANI A. AB. "Bed load transport without deposition in channels of circular cross section", 6th International Conference on Urban Storm Drainage, Niagara Falls, Ontario, Canada, september 12-17, 1993.

99. NALLURI C., GHANI A.AB. AND EL-ZAEMEY A.K.S. "Sediment transport over deposited beds in sewers", to be published in IAWQ Water Science \& Technology, Spring 1994.

100. NEZU I. AND RODI W. "Experimental study on secondary currents in open channel flow" Proceedings of 21st IAHR Congress, Melbourne, Australia, August 1985.

101. NEZU I. AND RODI W. "Open-channel flow measurements with a laser doppler anemometer", ASCE, Journal of Hydraulic Engineering, Vol. 112, May 1986.

102. NICHOLSON J. AND O'CONNOR B.A. "Cohesive sediment transport model", ASCE, Journal of Hydraulic Engineering, July 1986, pp. 621-640.

103. NOVAK P. AND NALLURI C. "Sediment transport in sewers and their sea outfalls", 4th Intenational Conference on Urban Storm Drainage, Lausanne, 1987.

104. O'BRIEN J.S. AND JULIEN P.Y. "Rheology of non-newtonian fine sediment mixtures", Proceedings ASCE Specialty Conference on Aerodynamics, Fluid Mechanics and Hydraulics, Minneapolis, 1986, pp. 989-996.

105. OCKENDEN M.C. AND DELO E.A. "Consolidation and erosion of estuarine mud and sand mixtures-An experimental study", Hydraulics Research Wallingford Report No SR 149, February 1988.

106. OTSUBO K. AND MURAOKA K. "Critical shear stress of cohesive bottom sediments", ASCE, Journal of Hydraulic Engineering October 1988, pp. 1241-1256.

107. OWEN M.W. "Problems in the modeling of transport, erosion and deposition of cohesive sediments", The Sea, Goldberg et al. ed., New York, 1977, Vol. 6, pp. 515-537. 
108. PANAGIOTOPOULOS I., COLLINS M.B., SILLS G.C. AND VOULGARIS G. "The influence of mud on the threshold of movement of sand: a laboratory study under currents and waves" Submitted to Sedimentology, April 1995.

109. PARCHURE T.M. AND MEHTA A.J. "Erosion of soft cohesive sediment deposits", ASCE, Journal of Hydraulic Engineering, October 1985, pp. 1308-1326.

110. PARKER W.R. "Cohesive sediment transport research", A report for SERC, University of Birmingham, Department of Civil Engineering, May 1986.

111. PARKER W.R. "On the characterisation of cohesive sediment for transport modellingConference overview" 4th Nearshore and Estuarine Cohesive Sediment Transport Conference INTERCOH'94, 11-15 July 1994, Wallingford, U.K.

112. PARTHENIADES E. "Erosion and deposition of cohesive soils", ASCE, Journal of the Hydraulics Division, January 1965, pp 105-139.

113. PARTHENIADES E. "Unified view of wash load and bed material load", ASCE, Journal of the Hydraulics Division, September 1977, pp. 1037-1057.

114. PARTHENIADES E. AND PAASWELL R.E. "Erodibility of channels with cohesive boundary", ASCE, Journal of the Hydraulics Division, March 1970, pp. 755-771.

115. PATERSON D.M. "Biological mediation of sediment erodibility: ecology and physical dynamics" 4th Nearshore and Estuarine Cohesive Sediment Transport Conference INTERCOH'94, 11-15 July 1994, Wallingford, U.K.

116. PATHIRANA K.P.P. "Modelling cohesive sediment transport in estuaries and coastal waters", PhD thesis, Katholieke Universiteit Leuven, February 1994.

117. PATHIRANA K.P.P. AND CHOSENI P.M. "Computer aided design and flow simulation of irrigation" M.Eng. theșis, Center for Irrigation Engineering, Katholieke Universiteit Leuven, 1989.

118. PENG-YEA MAA, SHANNON W.T., CHANGQUING L. AND LEE C.H. "In situ measurements of the critical bed shear stress for erosion", Environmental Hydraulics, Lee \& Cheung eds, 1991.

119. PERIGAUD C. "Mécanique de l'érosion des vases", La Houille Blanche, No. 7/8, 1983.

120. PÉRIGAUD C. "Erosion of cohesive sediments by a turbulent flow", Part I: Low mud concentration; Part II: High mud concentration, Journal de Mécanique Théorique et Appliquée, Vol. 103, No.4, 1984, pp. 491-519. 
121. PERRUSQUIA G. "Bedload transport in storm sewers, Stream traction in pipe channels", Report Series A:22, Chalmers University of Technology, Department of Hydraulics, 1991.

122. PROFITT G.T. AND SUTHERLAND A.J. "Transport of non-uniform sediments, IAHR, Journal of Hydraulic Research, Vol. 22, No. 1, 1983.

123. RANGA RAJU K.G. "Transport of sediment mixtures", 21st IAHR Congress, Melbourne, Australia, August 1985.

124. RAUDKIVI A.J. AND HUTCHINSON D.L. "Erosion of kaolinite clay by flowing water", Proceedings Royal Soc. London A., Vol. 337, 1974, pp. 537-554.

125. SAMAGA B.R., RANGA RAJU K.G. AND GARDE R.J. "Concentration distribution of sediment mixtures in open-channel flow", IAHR, Journal of Hydraulic Research, Vol. 23, No.5, 1985.

126. SAMAGA B.R., RANGA RAJU K.G. AND GARDE R.J. "Bed load transport of sediment mixtures", ASCE, Journal of Hydraulic Engineering, Vol. 112, November 1986.

127. SANFORD L.P. "Wave-forced resuspension of Upper Chesapeake Bay muds", Estuaries, 1994, Vol. 17, No.18, pp. 148-165.

128. SANFORD L.P. AND HALKA J.P. "Assessing the paradigm of mutually exclusive erosion and deposition of mud, with examples of the upper Chesapeake Bay", Marine Geology, 114, 1993, pp. 37-57.

129. SARgUNAM A., RILEY R., ARULANANDAN K. AND KRONE R.B. "Physicochemical factors in erosion of cohesive soils", ASCE, Journal of the Hydraulics Division, march 1979 , pp. 555-558.

130. SARMA A.K. "Velocity, shear and friction factor studies in subcritical rough turbulent open channel flows". PhD thesis, Indian Institute of Science, Bangalore 1993.

131. SCHAEKEN J. "Erosiegedrag van gelaagde zand/slib mengsels in uniforme stroming" Eindwerk Katholieke Industriële Hogeschool De Nayer, afdeling Bouwkunde, Mechelen, 1994 (in Dutch).

132. SHENG Y.P. "Consideration of flow in rotating annuli for sediment erosion and deposition studies" Journal of Coastal Research, Special Issue No. 5, 1989, pp. 207-216. 
133. SKIPWORTH P. "Behaviour of sediments in sewers", UPM Sediments Working Group meeting, University of Sheffield, 5/5/93.

134. TASK COMMITTEE ON EROSION OF COHESIVE MATERIALS "Erosion of cohesive sediments", ASCE, Journal of the Hydraulics Division, July 1968, pp. 1016-1049.

135. TEETER A. " Size dependent erosion of cohesive sediment" 4th Nearshore and Estuarine Cohesive Sediment Transport Conference INTERCOH'94, 11-15 July 1994, Wallingford, U.K.

136. TEISSON C. "Cohesive suspended sediment transport: feasibility and limitations of numerical modeling", IAHR, Journal of Hydraulic Research, 1991, No. 6, pp. 785-769

137. TERZAGHI K. AND PECK R.B. "Soil mechanics in engineering practice", J. Wiley \& Sons inc., New York, London, Sidney, 1967.

138. THIJSSE J.T. "Formulae for the friction head loss along conduit walls under turbulent flow", IAHSR, 3rd Meeting, Grenoble 1949.

139. TITO L., HUYGENS M. AND VERHOEVEN R. "Comparative study on erosional behaviour of non-cohesive and partly cohesive sediments in a cylindric flume" 8th International Conference on Transport and Sedimentation of Solid Particles, 1995, Prague.

140. TOORMAN E. "A review of the use of the concentric cylinder viscometer for cohesive sediment suspensions" 4th Nearshore and Estuarine Cohesive Sediment Transport Conference INTERCOH'94, 11-15 July 1994, Wallingford, U.K.

141. TOORMAN E. "Modelling of fluid mud flow and consolidation" $\mathrm{PhD}$ thesis, K.U.Leuven, 1992.

142. TOORMAN E. "Sedimentation and self-weight consolidation. Part I: General unifying theory." Accepted for publication in Géotechnique, 1995.

143. TOORMAN E. AND BERLAMONT J. "Settling and consolidation of mixtures of cohesive and non-cohesive sediments" Advances in Hydro-Science and Engineering, Vol. 1, 1993, S.Y Wang (ed.), pp. 606-613.

144. TORFS H. "Erosion of layered sand-mud beds in uniform flow", Proceedings of the 24th International Conference on Coastal Engineering, 23-28 October 1994, Kobe, Japan. 
145. TORFS H. "Erosion of mixed cohesive / non cohesive sediments in uniform flow", 4th Nearshore and Estuarine Cohesive Sediment Transport Conference INTERCOH'94, 11-15 July 1994, Wallingford, U.K.

146. TORFS H. "Erosional behaviour of partly cohesive, partly non cohesive sediments in uniform flow", proceedings of the 6th International Conference on Urban Storm Drainage, Niagara Falls, Ontario, Canada, september 12-17, 1993.

147. TORFS H. "Sedimenttranport meetcampagne op de Schelde nabij Temse", Water, 11de jaargang, No. 63, maart/april 1992.

148. TORFS $\mathbf{H}$. "Shape and scale effects on secondary currents and shear stress distributions in laboratory flumes", 2nd International Conference on Hydraulic Modelling, Development and Application of Physical and Mathematical Models, Stratford-uponAvon, 14-16 June 1994, pp 287-295.

149. TORFS H. AND HUYGENS M. "Erosion of partly cohesive, partly non cohesive sediments in uniform flow", Advances in Hydro-Science and -Engineering, S.Y. Wang ed. 1993.

150. TORFS H., HUYGENS M. AND TITO L. "Influence of the cross-section on the erosion criteria for partly cohesive sediments", I.A.W.Q. Water Science and Technology, Vol. 29, No. 1-2, 1994; pp. 103-111.

151. TORFS H., WILLIAMSON H. AND HUYSENTRUYT H. "Settling and consolidation of mud/sand mixtures" submitted to Coastal Engineering, 1995.

152. UMIDA T., KUSUDA T., FUTAWATARI T., AWAYA Y. AND ONUMA M. "A model of erosion of soft cohesive sediments", 3rd International Symposium on River Sedimentation, University of Mississippi, March 31 - April 4, 1986.

153. VAN DAMME P.M. "Slibgedrag in een natuurlijk milieu-Literatuurstudie" M.Eng. thesis, Civil Engineering Department, T.H. Delft, 1982 (in Dutch).

154. VAN DER VELDEN E.T.J.M. "De invloed van organisch materiaal op de eigenschappen van slib", interne nota, T.U. Delft, 1989 (in Dutch).

155. VAN DER VELDEN E.T.J.M. "De invloed van de $\mathrm{pH}$ en het elektroliet op het uitvlokken van slib", T.U. Delft, 1989 (in Dutch).

156. VAN DER VELDEN E.T.J.M. "Uitschuring rond pijpleidingen in slibhoudend zand", interne nota, T.U. Delft, 1989 (in Dutch). 
157. VAN KESTEREN W.G.M., WINTERWERP J.C., KUYPER C. AND CORNELISSE

J.M. "A new theory for the erosion of cohesive sediments", Proceedings of the 23rd International Conference on Coastal Engineering, 4-9 October 1992, Venice, Italy.

158. VAN RIJN L.C. "Handbook Sediment Transport by Currents and Waves", 1989.

159. VERBANCK M. (ed) "Origin, Occurrence and Behaviour of Sediments in Sewer Systems", Proceedings IAWQ/IAHR Workshop on Sewer Sediments, Brussels, Water Science \& Technology, Vol. 25, No. 8, 1992.

160. VERBANCK M.A., ASHLEY R.M. AND BACHOC A. "International workshop on origin, occurrence and behaviour of sediments in sewer systems: Summary of conclusions", Water Resources, Vol. 28, No. 1, 1994, pp. 187-194.

161. VERBEEK H. AND CORNELISSE J.M. "Erosion and liquefaction of natural mud under surface waves" 4th Nearshore and Estuarine Cohesive Sediment Transport Conference INTERCOH'94, 11-15 July 1994, Wallingford, U.K.

162. WARTEL S. "Shear velocity measurements and sediment transport in the Scheldt Estuary", Bull. Soc. belge Geol., Paleont., Hydrol., Brussels 1973.

163. WHITING P.J. AND DIETRICH W.E. "Boundary shear stress and roughness over mobile alluvial beds", ASCE, Journal of Hydraulic Engineering, Vol. 116, December 1990.

164. WIBERG P.L. AND SMITH J.D. "Calculations of the critical shear stress for motion of uniform and heterogeneous sediments, Water Resources Research, Vol. 23, No. 8, 1987, pp. 1471-1480.

165. WILCOCK P.R. AND SOUTHERD J.B. "Bed load transport of mixed size sediment: Fractional transport rates, bed forms, and the development of a coarse surface layer", Water Resources Research, Vol. 25, No. 7, 1989.

166. WILLIAMS D.J.A. AND WILLIAMS P.R. "Rheology of concentrated cohesive sediments" Journal of Coastal Research, Special Issue No. 5, 1989, pp. 165-175.

167. WILLIAMS D.J.A., WILLIAMS P.R. AND CRABTREE R.W. "Preliminary investigations into the rheological properties of sewer sediment deposits and the development of a synthetic sewer sediment material for laboratory studies", FWR Report No. FR 0016, September 1989. 
168. WILLIAMSON H. AND TORFS H. "Erosion of mud/sand mixtures" submitted to Coastal Engineering 1995.

169. WILLIAMSON H.J. "Tidal transport of mud/sand mixtures. Sediment distributions-A literature review", HR Wallingford, Report SR 286, 1991.

170. WILLIAMSON H.J. "Tidal transport of mud/sand mixtures" HR Wallingford, Report SR 372, September 1993.

171. WILLIAMSON H.J. AND OCKENDEN M.C. "Tidal transport of mud/sand mixtures, laboratory tests", HR Wallingford, Report SR 257, January 1992.

172. WILLIS D.H. AND CROOKSHANK N.L. "Modelling multiphase sediment transport in estuaries" 4th Nearshore and Estuarine Cohesive Sediment Transport Conference INTERCOH'94, 11-15 July 1994, Wallingford, U.K.

173. WOTHERSPOON D.J.J. "The movement of cohesive sediment in a large combined sewer", Ph.D. thesis, University of Abertay Dundee, December 1994.

174. WOTHERSPOON D.J.J. AND ASHLEY R.M. "Rheological measurement of yield strength of combined sewer sediment deposits", Water Science \& Technology, Vol. 25, No. 8, 1992.

175. WOTHERSPOON D.J.J., ASHLEY R.M. AND WOODS S.J. "Imaging in Sewer Systems", in Applications of Information Technology in Construction, ed. Maxwell J.W.S., Institution of Civil Engineers, Thos Telford, 1991, pp. 143-156.

176. YALIN M.S. AND KARAHAN E. "Inception of sediment transport", ASCE, Journal of the Hydraulics Division, Vol. 105, 1979, pp. 1433-1443. 


\section{Plates}

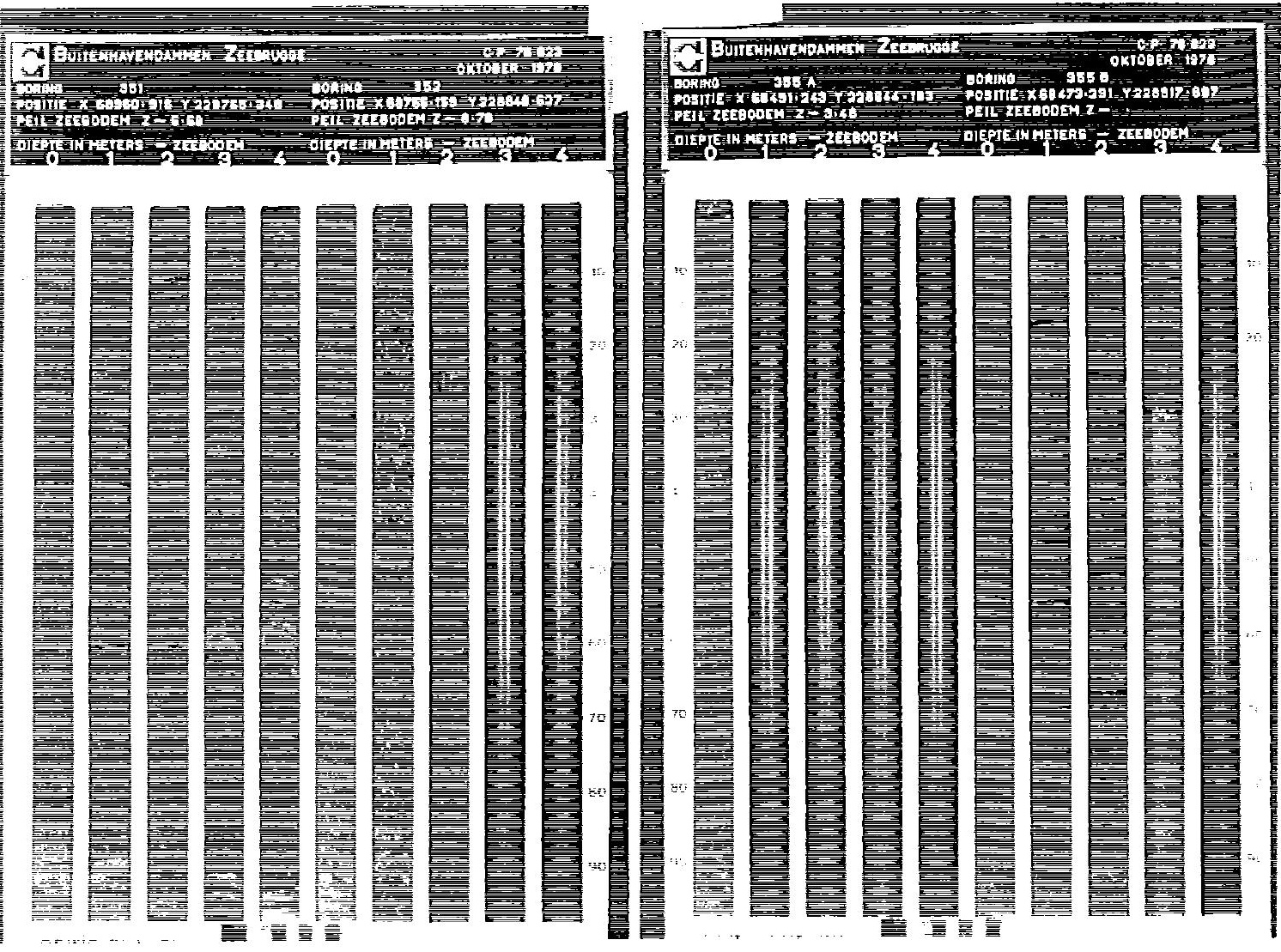

Plate 1: Core samples taken along the Belgian coast, near the entrance of the harbour of Zeebrugge. The sediment bed is highly stratified and colour differences clearly indicate the different layers. 


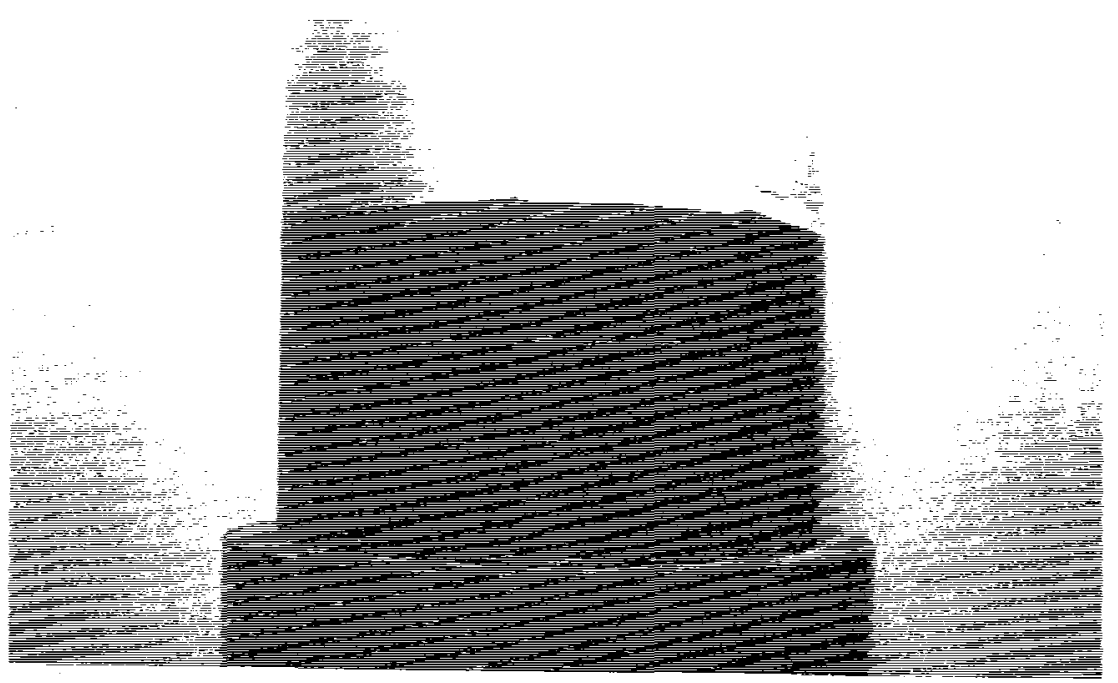

Plate 2a: Example of a stratified deposited bed formed in the settling column.

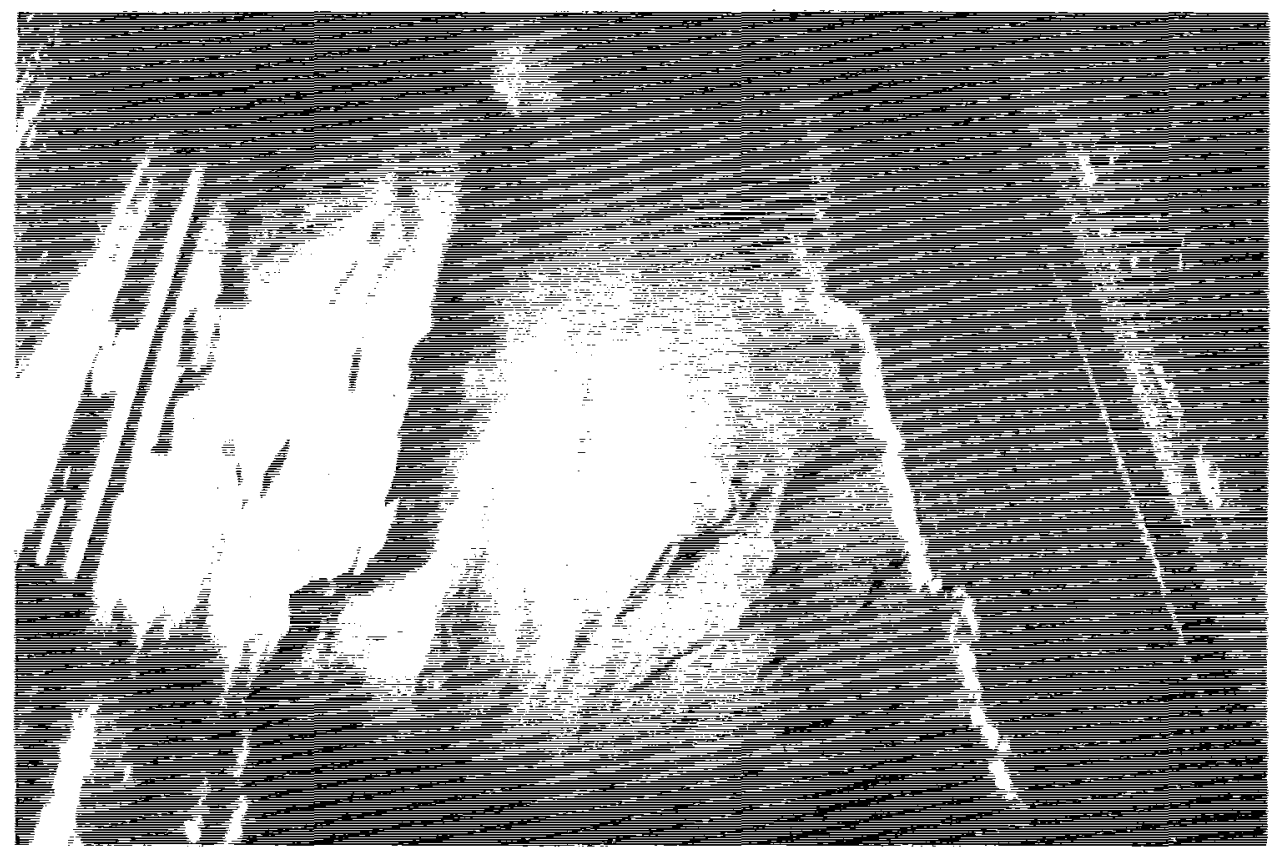

Plate 2b: View of the sediment bed after an erosion experiment on a layered deposited bed. In the middle of the cross section one layer has been removed. 
Plate 3: Overview of the structures formed inside different kaolinite/sand mixtures, as revealed by a scanning electron microscope, enlargement 150 times (160 for Plate 3c). The mixtures, containing between 0 and $20 \%$ fines, have been air-dried.

a. Mixture 1 contains about $5 \%$ fines. The angularity of the sand grains is still very clear. Due to the drying some kaolinite particles have settled onto the sand grain surface; normally they would be in suspension in the pores in between the sand particles. Those loose clay particles will be washed out from the surface layer at low bed shear stresses. The sand grains are in contact with each other but in some places, e.g. a little above the middle of the plate, a sort of clay "bridge" separates two grains: small threads of clay flocs connect the two grains. However, the erosion resistance is dominated by sand grain interlocking.

b. Mixture 2 contains $7.1 \%$ fines. The mixture looks a lot smoother and the number of "bridges" in between the sand grains has increased. The connections seem more tight and will start to play a role in determining the erosion resistance. However, there is still an important number of sand-sand interactions as well. The smoothening of the surface will increase the erosion resistance.

c. The amount of fines has increased to $9.2 \%$ for mixture 3 . The clay particles have formed a partial network around the sand grains, although the image is somewhat distorted by the drying process. Around this mixture composition, the cohesion starts to be the governing factor in the erosion resistance. The sand particles have lost contact with each other.

d. Mixture 4 contains $14 \%$ fines. The fine particles have formed a complete network structure around the sand grains. The network contains however some weak points, where only small bridges have been formed, that will control the erosion resistance. The erosion of such a mixture results in the removal of large units of sediment mixture, containing several sand particles glued together by the clay fraction.

e. Plate e shows mixture 5 containing $19.3 \%$ fines. The importance of the sand grains has been strongly reduced. The mixture is in fact a cohesive sediment containing some sand grains. Increasing the fine fraction even more will have a decreasing effect on the erosion resistance. The erodibility goes to a minimum, i.e. a maximum critical shear stress for erosion. 


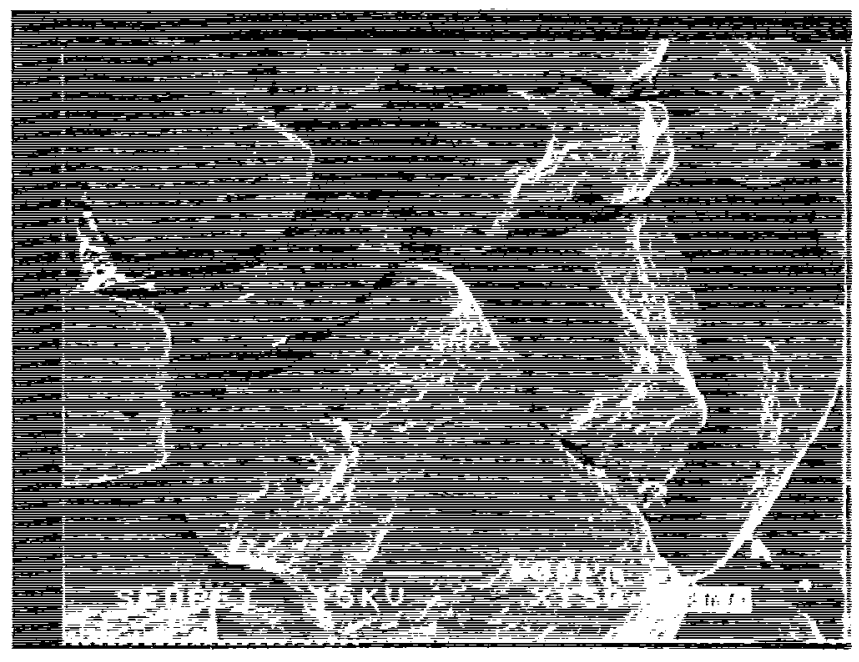

Plate 3a

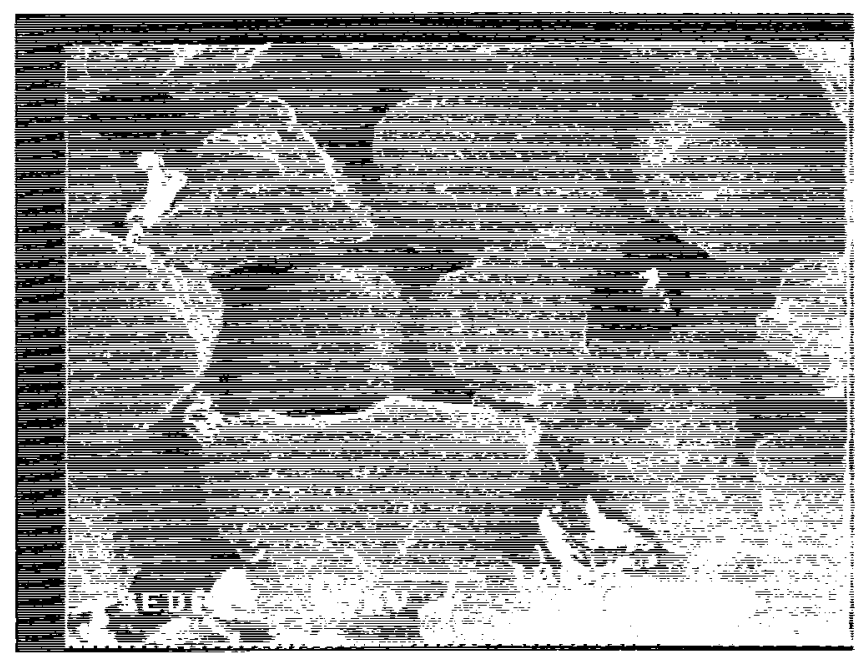

Plate 3b

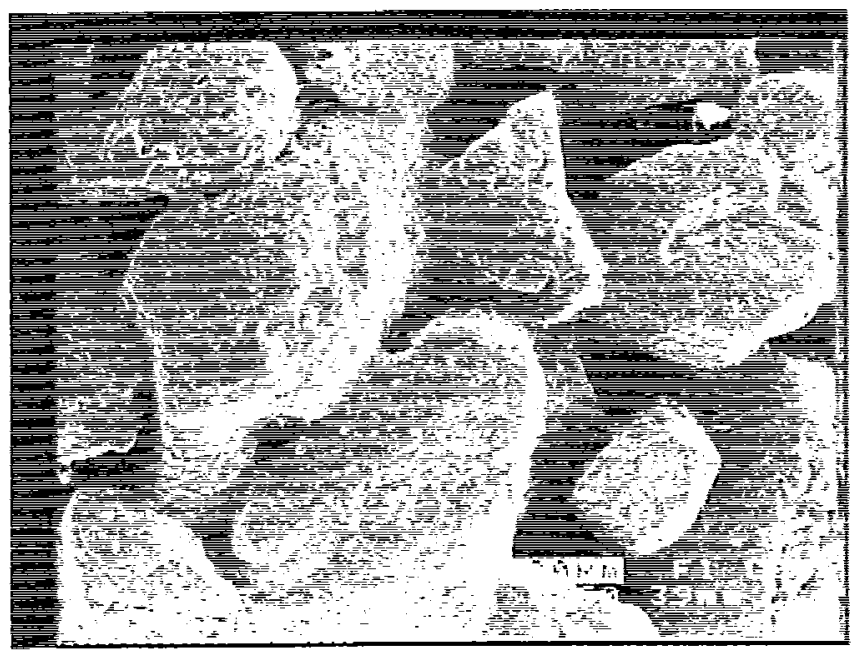

Plate $3 c$ 


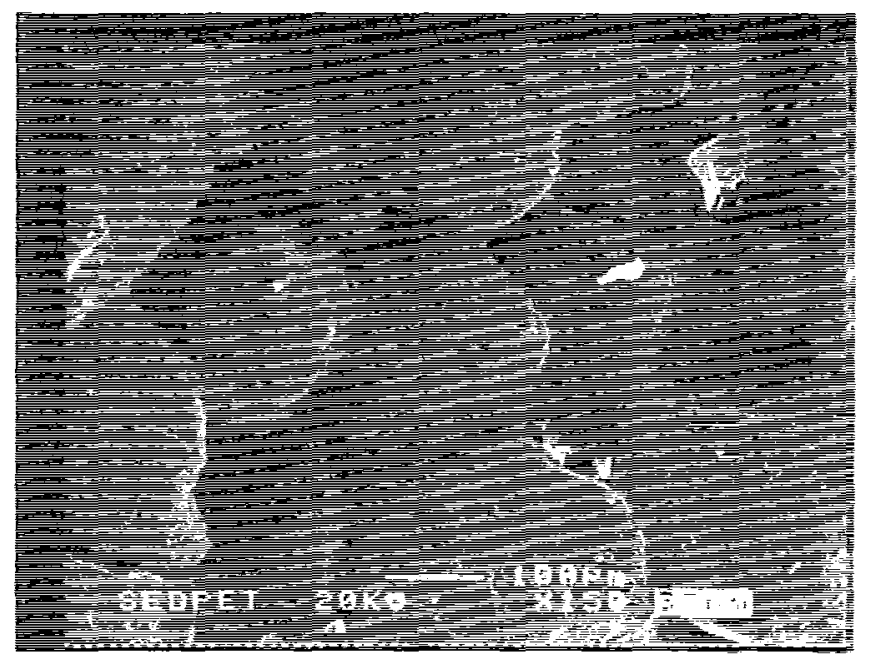

Plate $3 d$

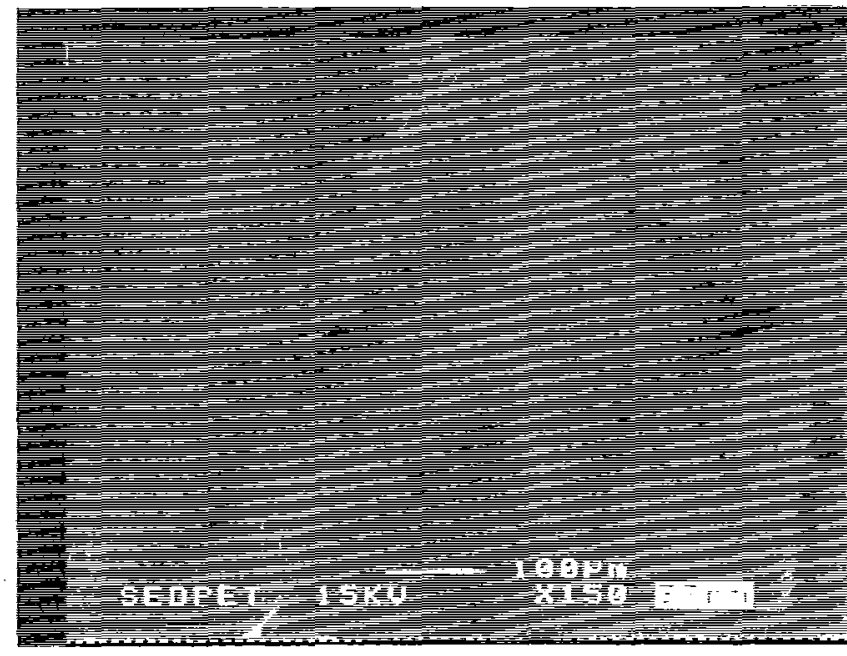

Plate 3e 
Plate 4: Details of the bridges formed in between sand grains with increasing amount of fines in the mixture. The plates correspond to the mixtures shown in Plate 3.

a. In mixture 1 some loose connections are formed locally in between sand grains. These connections are weak threads formed in "bottlenecks", i.e. where sand grains are almost touching each other. The bridged distances are of the order of magnitude of $10 \mu \mathrm{m}$. However, the picture shows that these bonds can very easily be broken and are in fact not important in the erosion resistance of the mixture.

b. For increasing amount of fines, mixture 2, more and more clay particles get trapped in these bottlenecks and the bridges get more solid, more resistant. The enlargement also shows the deposition of clay particles on the sand grains, probably due to the drying.

c. This picture shows an enlargement of the bonds formed between the two sand grains in the top left comer of Plate $3 \mathrm{c}$ (mixture 3 ). The amount of bonding keeps increasing as well as the covering of the sand grains by deposited clay.

d. For mixture 4, the transitions between the sand grains are now more or less completely made by clay comnections, that have taken over the governing role in the erosion resistance of the mixture.

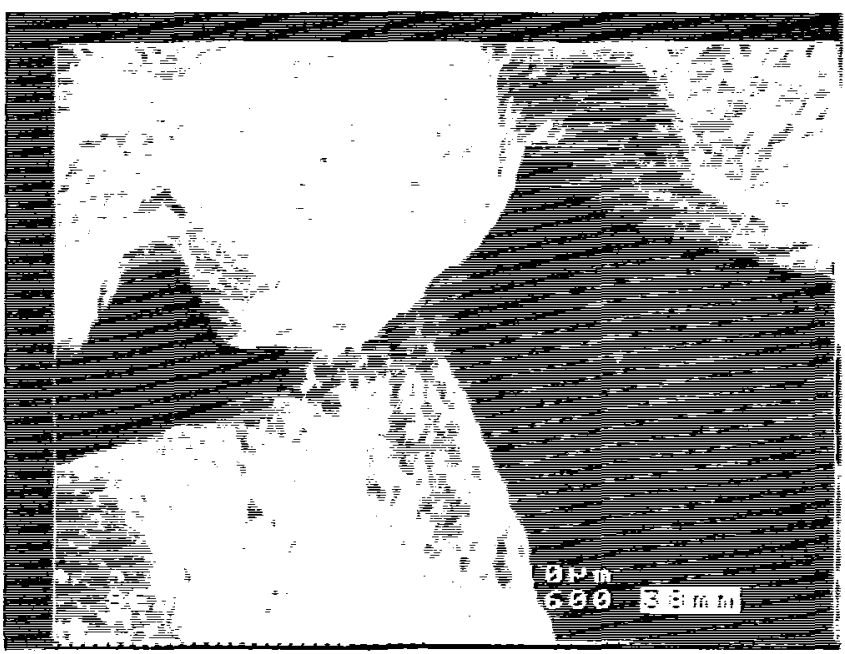

Plate $4 a$ 


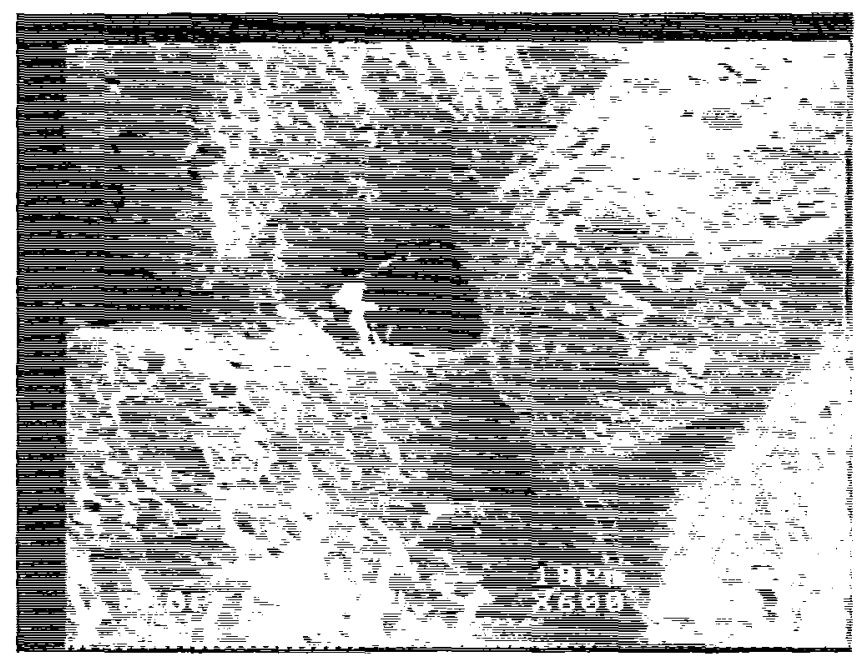

Plate 4b

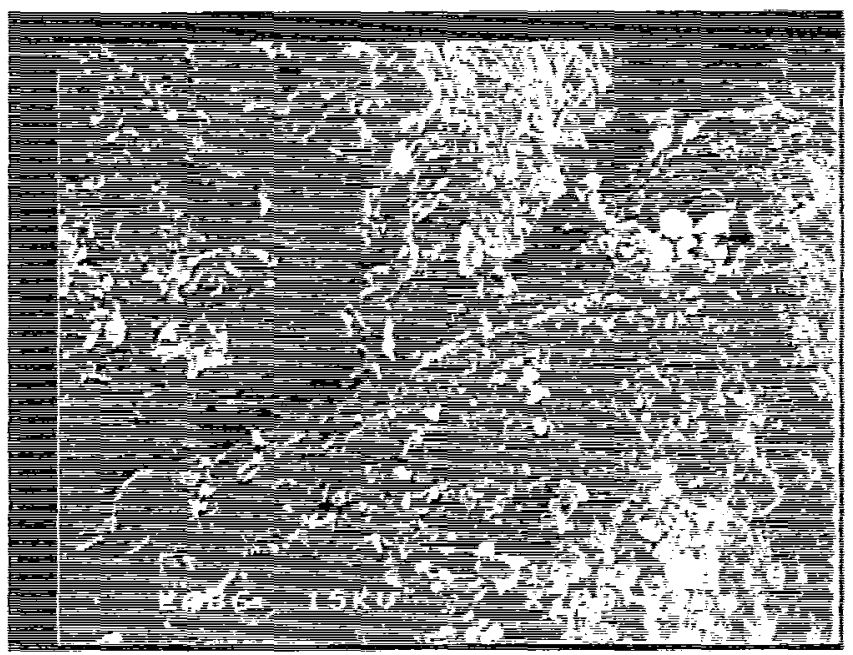

Plate $4 c$

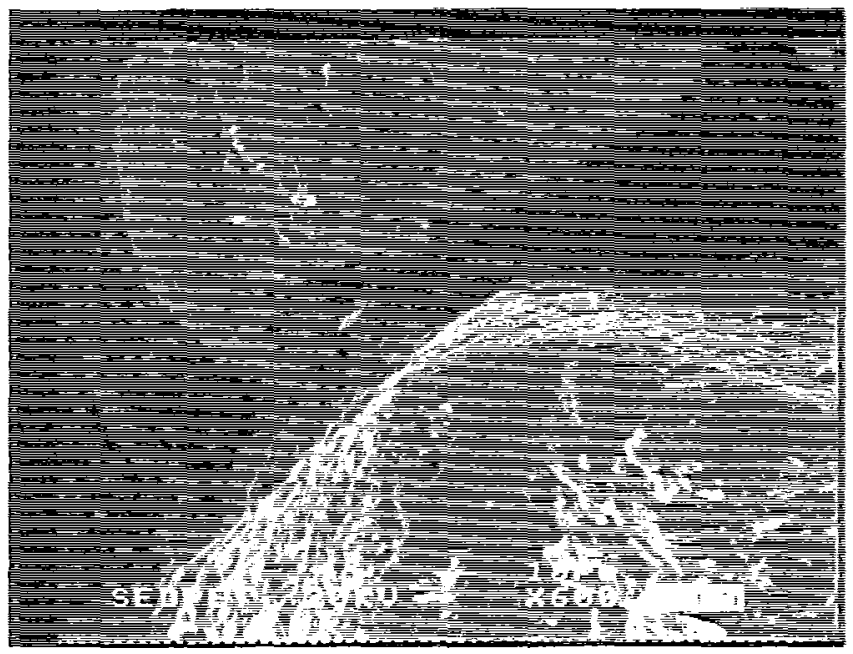

Plate 4d 
Plate 5: $\quad$ The plates represent mixtures 4 (Plate 5a) and 5 (Plate 5b), air-dried, but this time the samples were broken, to check if the same bonding mechanisms are also acting inside the bed. It is clear that the clay bonds between the particles form the weakest points, no sample is broken inside a sand grain. These pictures demonstrate that the formation of bridges and a network is not only a surface phenomena but occurs throughout the sample.

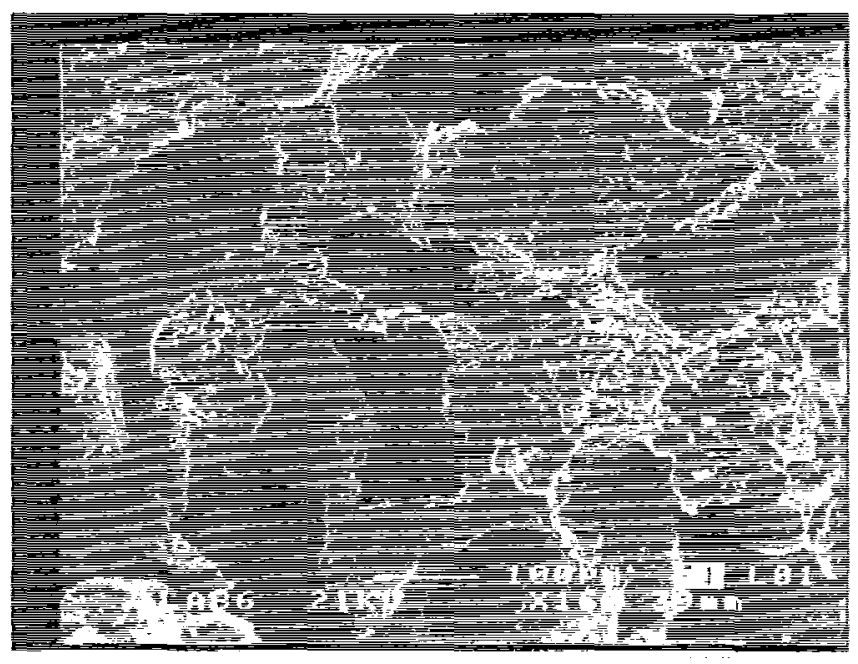

Plate 5a

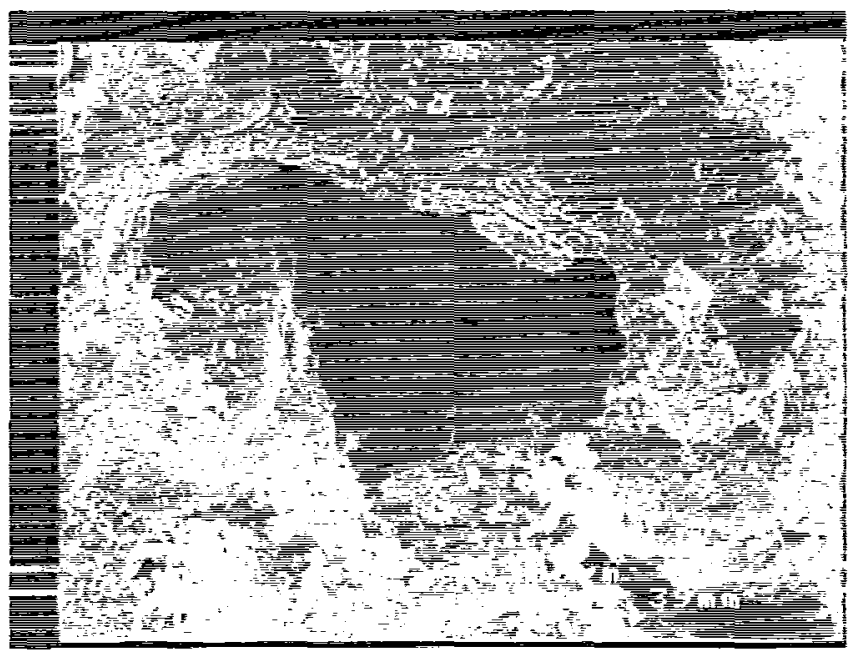

Plate 5b 
Plate 6: $\quad$ This picture shows strong enlargements of the clay plates inside mixtures 3 (Plate 6a), 4 (Plate 6b) and 5 (Plate 6c). The clay plates are randomly oriented, with some spots of parallel orientation. This is probably due to the drying process.

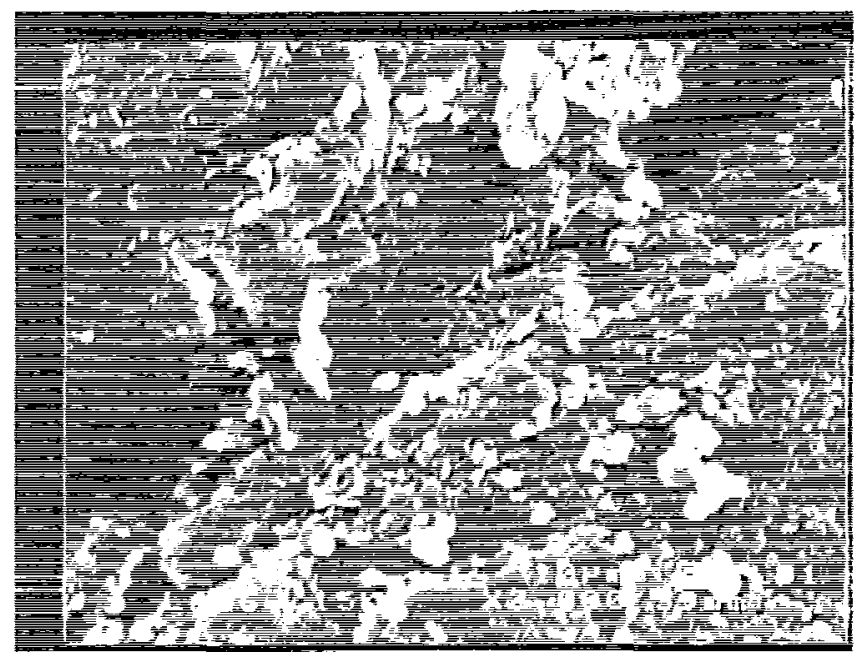

Plate 6a

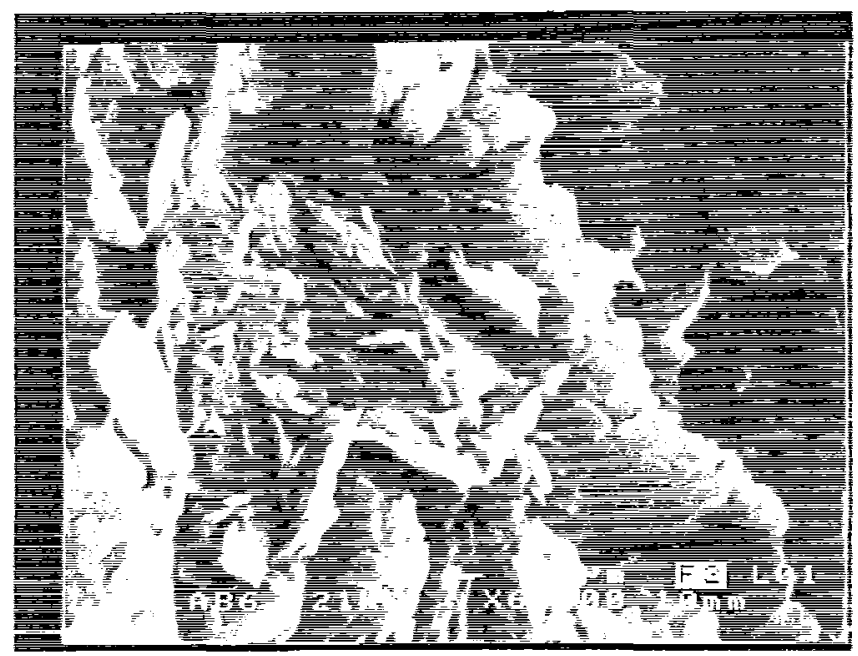

Plate $6 b$ 


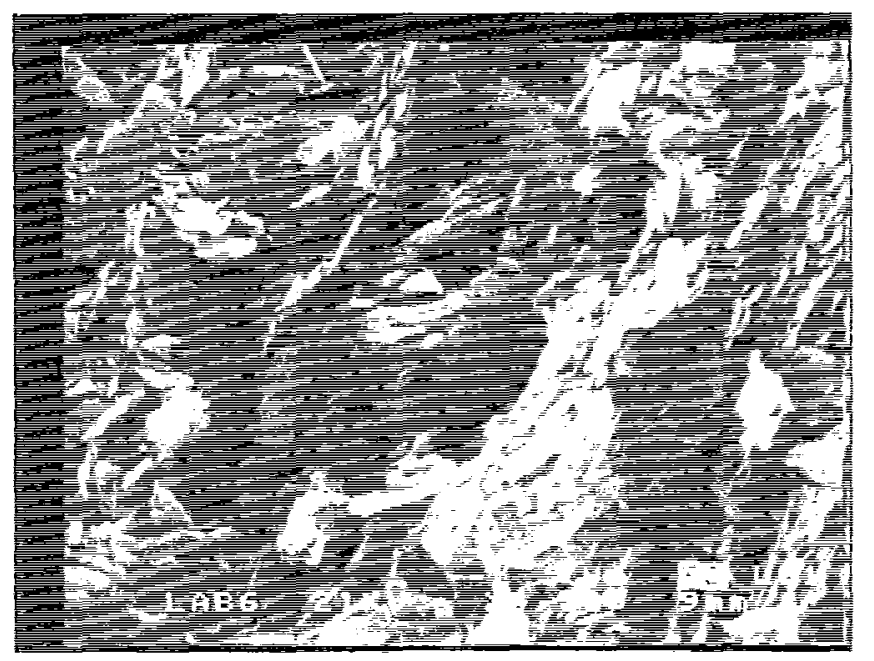

Plate 6c 
Plate 7: The picture shows a sample of mixture 1, low clay content (5\%fines). It demonstrates how a clay bridge grows from one sand grain to another. The start of such a bond is probably some clay particles getting trapped in a irregularity on the surface of a sand grain. Through electrochemical forces more and more clay particles come together and form a large aggregate that grows until it reaches another sand grain.

The sample in this plate has been dried very quickly at $105^{\circ} \mathrm{C}$, to assess the effects of drying. In comparison with the air dried samples, e.g. in Plate 6, the clay plates in Plate $7 \mathrm{c}$ are more parallel. Due to the rapid drying the structure collapsed totally.

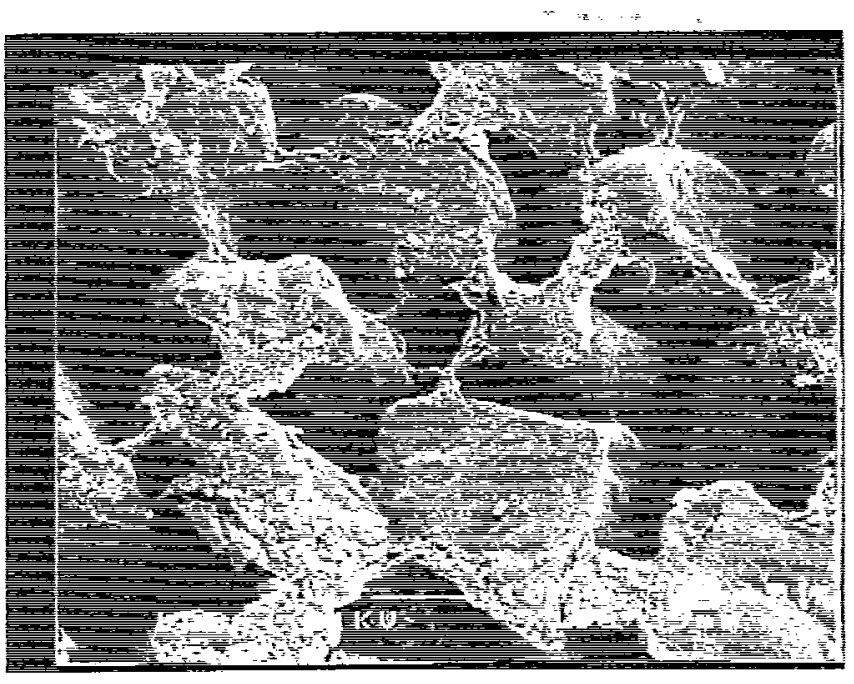

Plate 7a 


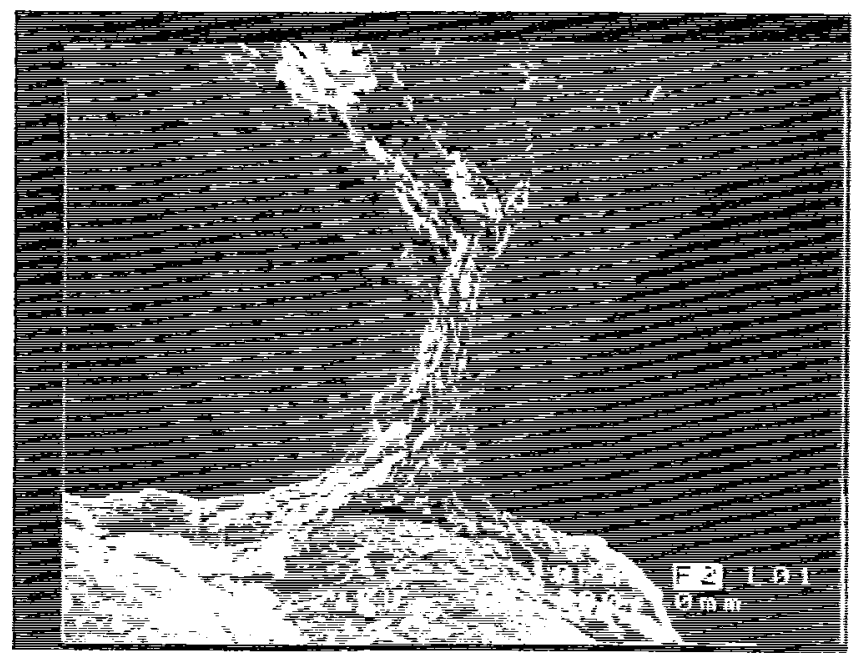

Plate $7 b$

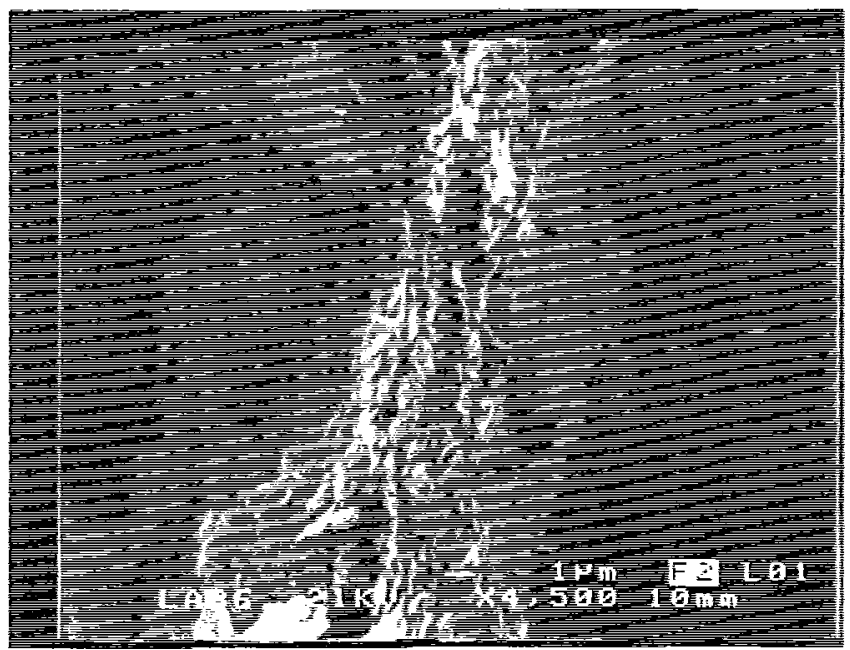

Plate 7c 


\section{Appendix 1:}

\section{Calculation of the bed shear stress}

\section{using a side wall elimination technique}

Most laboratory flumes are channels of composite roughness: the bottom or sediment bed is usually rougher than the flume walls. Moreover, the presence of the walls reduces the longitudinal flow velocities in the vicinity of the walls and hence, the local shear stresses. As a result, the overall shear stress, calculated from the mean flow conditions as $\rho g R S_{e}$, differs from the bed shear stress. To calculate the bed shear stress several empirical methods exist. The method used in this thesis was published by Vanoni and Brooks in 1957 (French 1985, pp. 175181) and splits up the hydraulic radius in two parts: one for the bed-related section and one for the wall-related region.

The following symbols will be used in this appendix:

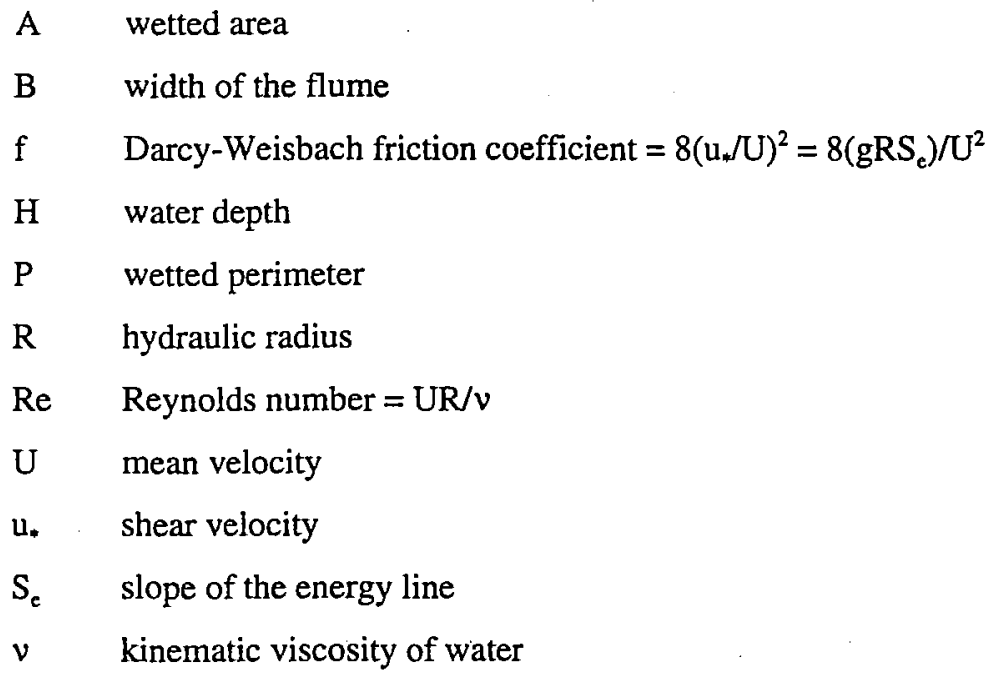

Each of these can be applied to the full section, but also to the wall region, indicated by subscript $w$, or to the bed region, indicated by subscript $b$. 


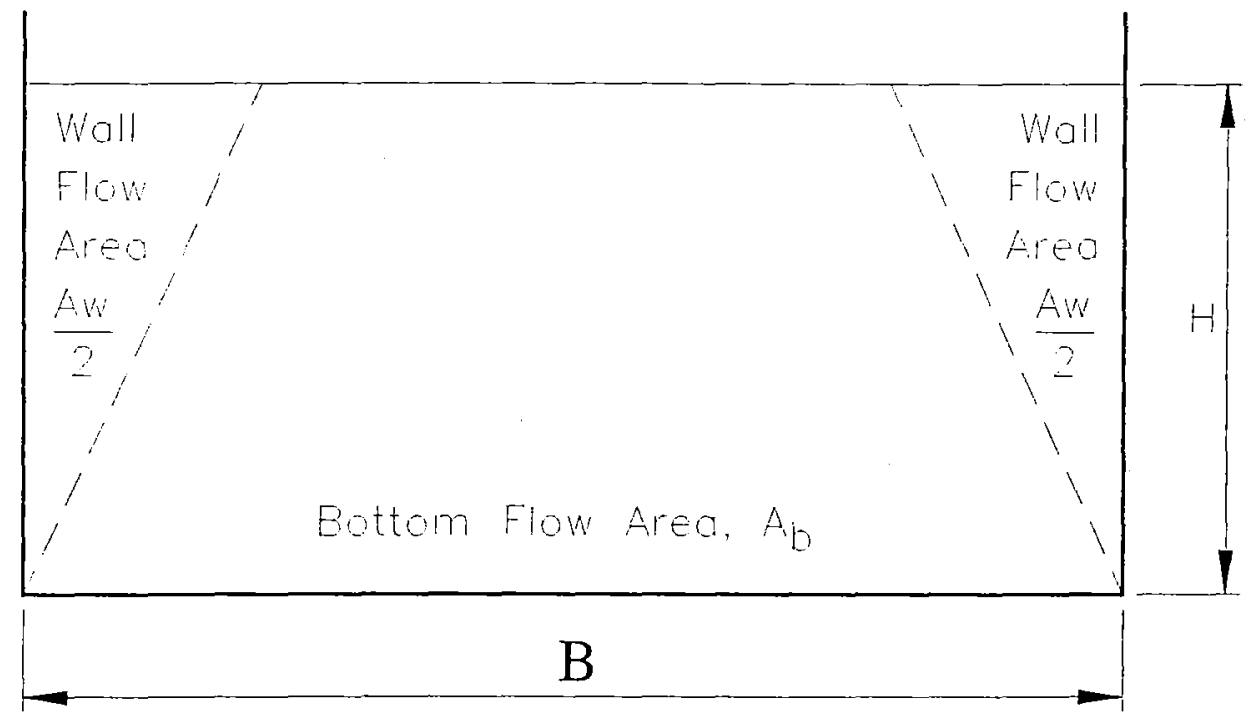

Figure A1.1: Division of the wetted area into wall- and bed-related regions.

The applied correction method is based on the following assumptions:

1. The cross section can be divided into two parts (Figure A1.1): one section in which the flow produces shear on the bottom, $A_{b}$, and one in which the flow produces shear on the walls, $A_{w}$. Both sections act as independent flow channels.

2. The perimeter of each section $\left(\mathrm{P}_{\mathrm{b}}=\mathrm{B}\right.$ and $\left.\mathrm{P}_{\mathrm{w}}=2 \mathrm{H}\right)$ has a constant roughness, although wall and bed roughness are different.

3. The mean flow velocities in both sections are equal, $\mathrm{U}_{\mathrm{b}}=\mathrm{U}_{w}$, and they are equal to the overall mean velocity, $U$.

Detailed flow measurements in a rectangular flume with varying bed roughness (Knight et al. 1979) have shown that the first assumption, the existence of two independent flow channels, is untenable. Significant momentum exchange between the two sections occurs. However, the researchers did find reasonably accurate results for the bed shear stress calculations using the side wall elimination technique. 
From the total flow conditions the following parameters are assumed to be known: R, U, A, P, $\mathrm{u}_{*}$ as well as $\mathrm{P}_{\mathrm{w}}$ and $\mathrm{P}_{\mathrm{b}}$

The primary unknowns are $f_{b}, R_{b}$ and $u_{* b}$.

The estimation of the wall friction factor $f_{w}$ is crucial to the solution of the problem. Therefore hydraulically smooth walls are assumed, for which the friction factor is only a function of the wall Reynolds number $\left(\operatorname{Re}_{w}\right)$, according to the equation of Nikuradse for smooth walls:

$$
f_{w}=0.0032+\frac{0.221}{\left(4 \operatorname{Re}_{w}\right)^{0.237}}
$$

Using the definition of the Reynolds number and since the mean flow velocity in all sections is the same:

$$
\frac{\mathrm{Re}_{w}}{\mathrm{R}_{\mathrm{w}}}=\frac{\mathrm{Re}}{\mathrm{R}}=\frac{\mathrm{U}}{\nu}
$$

From the definition of the friction factor:

$$
\frac{R}{f}=\frac{R_{w}}{f_{w}}=\frac{R_{b}}{f_{b}}=8 \mathrm{gSe} / U^{2}
$$

Combining the previous two equations yields:

$$
\frac{\operatorname{Re}}{f}=\frac{\operatorname{Re}_{w}}{f_{w}}=\frac{\operatorname{Re}_{b}}{f_{b}}
$$

Rearranging equation (A1.1) gives:

$$
f_{w}^{1.237}-0.0032 f_{w}^{0.237}=\frac{0.159}{\left(\operatorname{Re}_{w} / f_{w e}\right)^{0.237}}
$$

Hence, since $R e / f$ and thus $\operatorname{Re}_{w} / f_{w^{\prime}}$ is known, equation (A1.5) can be used to calculate $f_{w}$. From geometrical considerations (Figure A1.1):

$$
A=A_{b}+A_{w}
$$


Using a slight modification of the definition of the friction factor:

$$
A=\frac{P f U^{2}}{8 g S_{e}}
$$

for each sub-section, knowing that the slope of the energy line $S_{e}$ is a constant, equation (A1.6) leads to:

$$
f_{b}=f+\frac{2 H}{B}\left(f-f_{w}\right)
$$

Finally, using equations (A1.2, A1.3) the hydraulic radius related to the (sediment) bed, $R_{b}$, can be calculated from $f_{b}$.

The bed shear stress is then

$$
\tau_{b}=\rho g R_{b} S_{e}
$$




\section{Appendix 2:}

\section{Accuracy of the experimental data}

The accuracy of the experimental data depends on many different factors: the accuracy of the measuring instruments, as mentioned in Chapter 3, the data processing techniques and the experimental procedures. Knowing the magnitude of the induced errors is important for the interpretation of the results of the erosion experiments. Therefore the accuracy of the experimental data will be discussed in detail in this appendix. The following table gives an overview of all the measured parameters and the estimated errors made during their determination.

\begin{tabular}{|c|c|c|c|}
\hline Parameter & Units & Minimum - Maximum & Percentage error \\
\hline Water level & $\mathrm{m}$ & $0.03-0.25$ & $2 \%$ \\
\hline Discharge & $1 / \mathrm{s}$ & $3.0-70.0$ & $4 \%$ \\
\hline Point velocity & $\mathrm{m} / \mathrm{s}$ & $0.05-0.80$ & $6 \%$ \\
\hline Mean velocity & $\mathrm{m} / \mathrm{s}$ & $0.10-0.75$ & $6 \%$ \\
\hline Cumulated bed load & $\mathrm{kg}$ & $0.00-500.00$ & $1 \%$ \\
\hline Suspended load concentration & $\mathrm{g} / \mathrm{l}$ & $0.001-0.1$ & $30 \%$ \\
\hline Slope of the energy line & - & $0.000-0.010$ & $15 \%$ \\
\hline Sediment transport (bed load) & $\mathrm{kg} / \mathrm{s}$ & $0.000-0.100$ & $<10 \%$ \\
\hline (suspended load) & $\mathrm{kg} / \mathrm{s}$ & $0.000-0.050$ & $60-100 \%$ \\
\hline Erosion rate & $\mathrm{kg} / \mathrm{sm}^{2}$ & $0.00001-0.01$ & $<10 \%(100 \%)$ \\
\hline Bed shear stress & $\mathrm{Pa}$ & $0.10-5.00$ & $<25 \%$ \\
\hline
\end{tabular}

In the following paragraphs the sources of the errors are summed up. For each parameter the errors are calculated for a typical example. It is assumed that these examples are representative and hence these values are used as the estimated errors in the last column of the above table. 
Only for very small values of the measured parameters, the errors may be significantly larger than those mentioned in the table.

\section{A2.1 Water level}

According to the supplier, the used type of pressure transducers shows a non-linearity and hysteresis error of $0.1 \%$ of the full scale. The maximum output signal of the transducer (and for all the instruments connected to the data logging system) is $5 \mathrm{~V}$. This means that $0.1 \%$ of the full scale is $0.005 \mathrm{~V}$. Furthermore, the data logging system, that measures the incoming voltages and stores them on data files, has an accuracy of $0.001 \mathrm{~V}$. The water level in the flume, and hence the output signal of the pressure transducer, is fluctuating in time, as shown in Figure A2.1. Using the time series of data (typically one measurement every $20 \mathrm{~s}$ ) an average output voltage and a standard deviation can be calculated. The error on the fluctuating signal is taken equal to two times the calculated standard deviation, as demonstrated in Figure A2.1. The full line represents the average reading and the dashed line the upper and lower limit of the signal (i.e., the average plus or minus two times the standard deviation). For this case the average value was $1.126 \mathrm{~V}$, with a standard deviation of $0.007 \mathrm{~V}$ and hence an error of $0.014 \mathrm{~V}$. When the errors are put together, the total error on the output signal $(\Delta V)$ of the pressure transducer is $0.020 \mathrm{~V}$.

To calculate the water level $(\mathrm{H})$ from the output voltage, a previously determined linear calibration formula is used: $\mathrm{H}=\mathrm{aV}+\mathrm{b}$. Examples of these calibration formulas are given in Figure 3.2. For the following calculations we used the equation for the downstream level. The linearity of the calibration formula is extremely good. The output of the regression analysis gives also the standard errors on coefficient a and intercept $b$. In this case $a=11.109 \mathrm{~cm} / \mathrm{V}$, $\Delta \mathrm{a}=0.114 \mathrm{~cm} / \mathrm{V}, \mathrm{b}=-2.242 \mathrm{~cm}$ and $\Delta \mathrm{b}=0.158 \mathrm{~cm}$. 


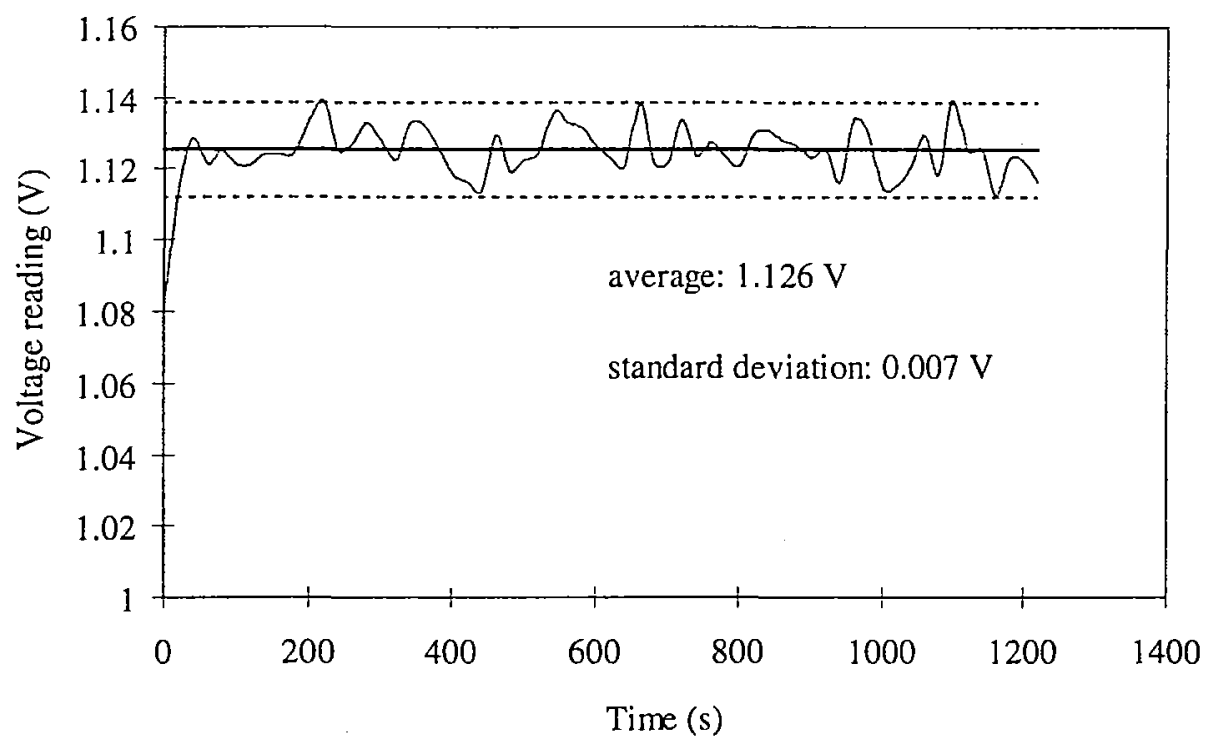

Figure A2.1: Output signal of the pressure transducer.

The total error on a parameter is calculated as follows: the error on each of the factors involved in the calculation of that parameter should be multiplied by its partial derivative of the calibration formula and these partial errors should be summed up to get the total error. In other words, if parameter $X$ is a function ( $f$ ) of $x_{1}, x_{2}, \ldots x_{n}$, the error $(\Delta X)$ is by definition:

$\Delta \mathrm{X}=\sum_{\mathrm{i}=1}^{\mathrm{n}} \Delta \mathrm{x}_{\mathrm{i}} \frac{\partial \mathrm{f}}{\partial \mathrm{x}_{\mathrm{i}}}$

For the water level this gives: $\Delta \mathrm{H}=\mathrm{a} \Delta \mathrm{V}+\mathrm{V} \Delta \mathrm{a}+\Delta \mathrm{b}$

Hence we can calculate the water level $\mathrm{H}$ as $10.27 \mathrm{~cm}$. For the given example the error on the water level is $0.51 \mathrm{~cm}$, which corresponds to $5 \%$ of the water level. Of course this is the error on one measurement. During an experimental run, water levels are registered every $20 \mathrm{~s}$, which for a short experiment of 30 minutes already means 90 measurements that are averaged to calculate the water level. Averaging over a large number of data significantly reduces the errors. As a remark it should be mentioned that the data used in the averaging do not take into account the initial strong fluctuations (Figure A2.1) due to transition from one discharge to another. On 
the other hand, once erosion occurs, the bed level, which is the reference for the water level measurements, changes in time. The erosion process reduces the accuracy. But it is safe to say that the error on the measured time average water level is only 1 or $2 \%$, as long as the erosion is not too severe.

\section{A2.2 Discharge}

The electromagnetic flow-meter that is used to measure the discharge through the flume, has been compared with other discharge measuring techniques by the Hydraulics Laboratory of the Universiteit Gent. They found an instrumental error of about $1 \%$, which means about $0.050 \mathrm{~V}$. The signal fluctuates around a time average value as plotted in Figure A2.2 and the error due to those fluctuations is taken as two times the standard deviation of the fluctuations. For the example of Figure A2.2 the average voltage is $1.011 \mathrm{~V}$ and the error is $\mathbf{0 . 0 1 8} \mathrm{V}$. Adding the $0.001 \mathrm{~V}$ accuracy of the data logging system, the total error on the discharge output signal is $0.069 \mathrm{~V}$.

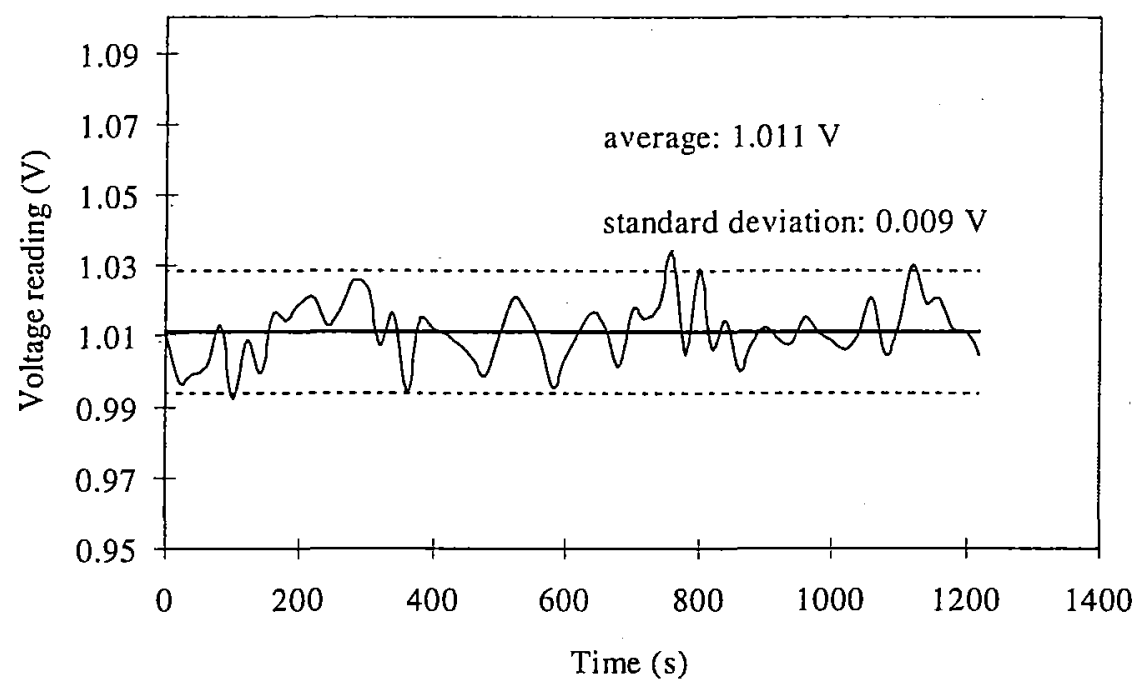

Figure A2.2: Output signal of the electromagnetic flow-meter. 
The calibration of the flow-meter gives the following linear equation $(r=0.99)$ to convert the output signal into a flow rate: $Q=20.085 \mathrm{~V}-1.361$ and the errors on the coefficient $(0.361 / \mathrm{s} / \mathrm{V})$ and the intercept $(0.64 \mathrm{l} / \mathrm{s})$ have been determined. Hence, using a similar method as for the water level, the error on the discharge can be calculated for the given example of Figure A2.2. The discharge is $18.9 \mathrm{l} / \mathrm{s}$ and the error $\Delta \mathrm{Q}$ is $2.4 \mathrm{l} / \mathrm{s}$. The error is more than $10 \%$ of the actual value. But again due to time averaging the accuracy increases. In this case the erosion has no effect on the flow rate through the flume. As an estimate we take the error to be 3 to $4 \%$.

\section{A2.3 Point velocity}

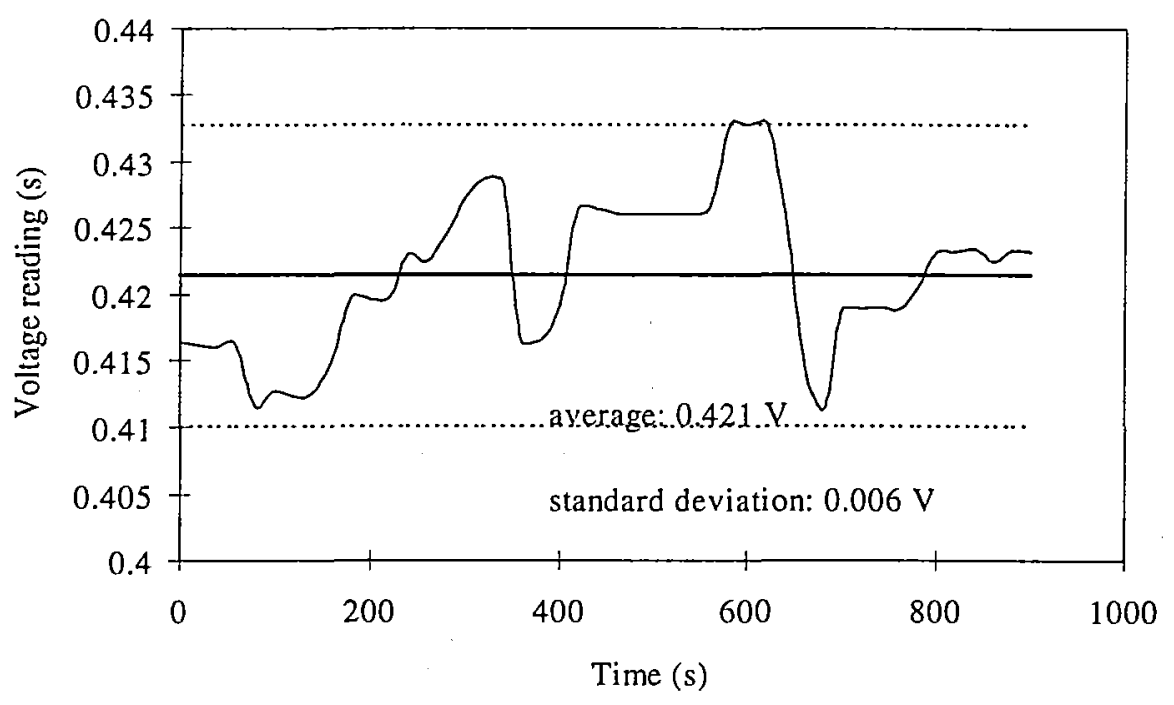

Figure A2.3: Output signal of the differential pressure transducer.

The errors due to hysteresis and non-linearity of the differential pressure transducer are estimated by the producer to be $0.5 \%$ of the full scale, i.e. $0.025 \mathrm{~V}$. An example of the time fluctuations is given in Figure A2.3. The stepped shape of this curve could be due to clogging of the pitot tube from time to time. Here, the average voltage is $0.421 \mathrm{~V}$ and the error $0.012 \mathrm{~V}$. This brings the total error on the output signal of the differential transducer, as registered by the data logging system, to $0.038 \mathrm{~V}$. Errors induced by the use of the pitot tube itself are neglected; the head losses in the tube should be almost zero. 
To calculate the velocity the linear calibration formula of Figure 3.2 is used. This equation converts the measured voltage into a pressure height for the velocity $\left(h_{u}\right): a=0.242 \mathrm{~cm} / \mathrm{V}$ $\pm 0.010 \mathrm{~cm} / \mathrm{V}$ and $\mathrm{b}=-0.064 \mathrm{~cm} \pm 0.022 \mathrm{~cm}$.

The actual velocity is then: $u(z)=\sqrt{0.02 \mathrm{gh}_{u}}=\sqrt{0.02 \mathrm{~g}(\mathrm{aV}+\mathrm{b})}$ or $0.433 \mathrm{~m} / \mathrm{s}$ (notice the conversion from centimetres to metres for the pressure height).

From the errors on $\mathrm{V}$, $\mathrm{a}$ and $\mathrm{b}$ the total error on the point velocity can be calculated as:

$\Delta \mathrm{u}=\frac{\sqrt{0.02 \mathrm{~g}}}{2}\left[\frac{\Delta \mathrm{a} \mathrm{V}}{\sqrt{\mathrm{a}}}+\frac{\Delta \mathrm{V} \mathrm{a}}{\sqrt{\mathrm{V}}}+\frac{\Delta \mathrm{b}}{\sqrt{\mathrm{b}}}\right]$ or $0.051 \mathrm{~m} / \mathrm{s}$, which is about $12 \%$ of the velocity. The actual point velocity is the average of a limited number of readings, since the position of the pitot tube is regularly changed during an experiment to cover the whole velocity profile. Hence the actual accuracy of a point velocity measurement is taken to be 5 to $6 \%$.

\section{A2.4 Mean velocity}

The average velocity $U$ is calculated from the time average discharge and the flow area $(A)$ : $U=Q / A$. The flow area is the product of the width $(B)$ of the flume and the water level $(H)$. The width of the flume is assumed to be a constant (i.e. negledgible errors). Hence $\Delta A=B \Delta H$ and the error on the average velocity is $\Delta \mathrm{U}=\frac{\Delta \mathrm{Q}}{\mathrm{A}}+\frac{\mathrm{Q} \Delta \mathrm{A}}{\mathrm{A}^{2}}$

For the values of discharge and water level given above the average velocity is $0.461 \mathrm{~m} / \mathrm{s}$ and the corresponding error is $0.028 \mathrm{~m} / \mathrm{s}$ or $6 \%$ of the average velocity.

\section{A2.5 Bed load}

The bed load or the cumulative weight of the sediment trap is registered by a load cell, with a non-linearity and hysteresis error of $0.05 \%$ of the full scale, which means $0.0025 \mathrm{~V}$. Due to the fluctuations in the flow over the sediment trap, the reading of the load cell fluctuates as well, even when no sediments are being eroded. An example of those fluctuations is given in 
Figure A2.4. The average value is $0.879 \mathrm{~V}$ and the error is $0.0002 \mathrm{~V}$. So the total error on the output signal of the load cell, including the accuracy of the data logging system, is about $\mathbf{0 . 0 0 4} \mathrm{V}$.

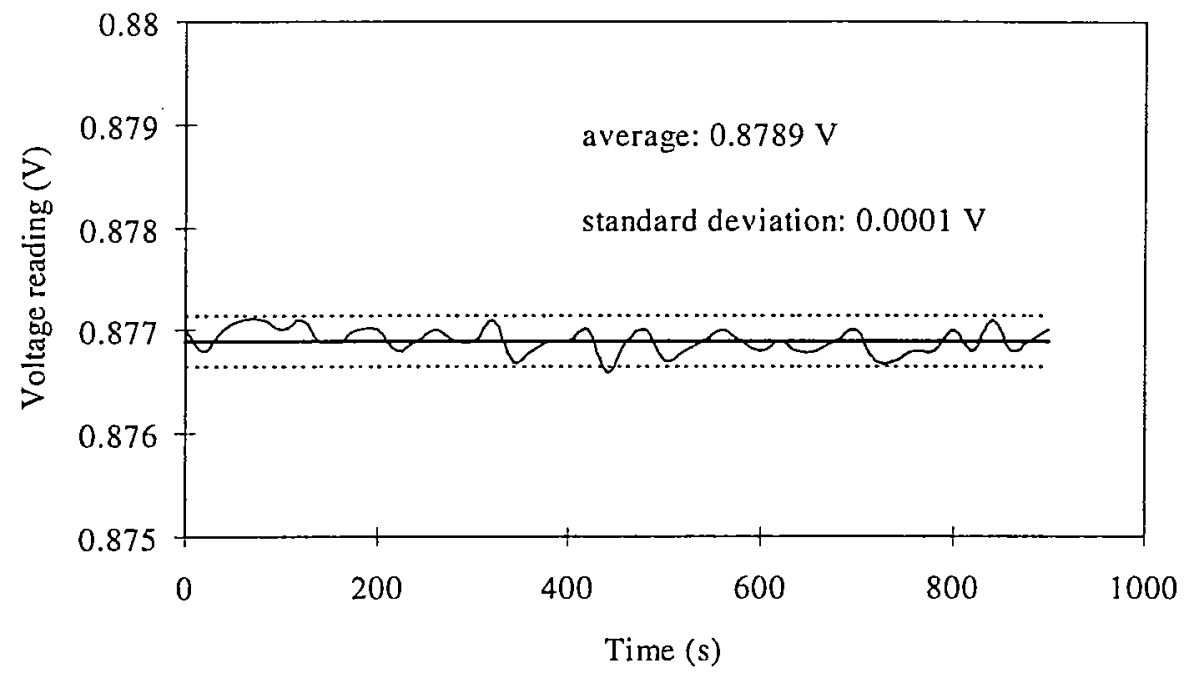

Figure A2.4: Output signal of the load cell.

To convert the reading into weight the calibration coefficient is $102.575 \mathrm{~kg} / \mathrm{V}$, the error on that coefficient is $0.322 \mathrm{~kg} / \mathrm{V}$. So the weight (W) for the reading given in Figure A2.4 is $90.153 \mathrm{~kg}$ and the error $\Delta W$ is then $0.522 \mathrm{~kg}$, which is less than $1 \%$. Time averaging of the signal reduces the error even more.

\section{A2.6 Suspended load}

To determine the suspended load, samples of the suspension are taken at regular time intervals. The volume (V) of the samples was $0.5 \mathrm{I}$ with an error of $\mathbf{0 . 0 2} \mathrm{l}$. The samples are filtered and dried. Then the weight of the dry filters with the sediments is compared to the weight of the empty filters in order to calculate the weight of suspended sediment. A typical value of $W_{s}$ is $0.001 \mathrm{~g}$, the error of the balance is $0.0001 \mathrm{~kg}$, but since the actual weight is determined as a difference between two values, the error on the suspended solids $\left(\Delta W_{s}\right)$ is $0.0002 \mathbf{g}$.

The concentration (C) is hence $0.002 \mathrm{~g} / \mathrm{l}$ and the error $\Delta \mathrm{C}$ can be calculated as: 


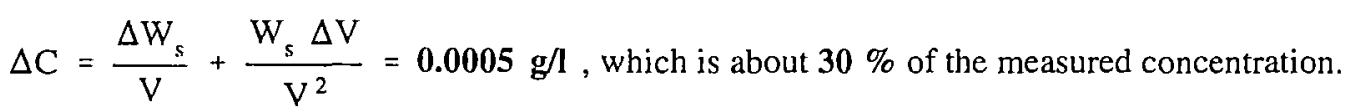

Due to the time consuming filtration procedure, the measurements were not repeated for one time step, so no averaging can be done to reduce the errors.

\section{A2.7 Slope of the energy line}

The slope of the energy line is calculated from the water surface profile through the upstream and downstream water level. Uncertainties on these water levels will cause errors on the calculated slope of the energy profile, but also the discharge is an input to the calculation of the water surface profile. A sensitivity analysis has shown that variations of $2 \%$ of the water level and $4 \%$ of the discharge create errors up to $15 \%$ on the slope of the energy line.

\section{A2.8 Sediment transport}

The bed load transport is calculated from the slope of the cumulated weight plotted versus time. The weight registered by the load cell is the submerged weight of the grains caught by the sediment trap. To convert this value into dry sediment weight it is multiplied by $2650 / 1650$ or 1.606. The slope of the curve is the difference between two weight values divided by the time interval. This time interval is assumed to be correctly measured.

So, the error on the bed load transport $\left(\Delta S_{b}\right)$ is two times the error on the bed load divided by the time interval and multiplied by 1.606. The accuracy is hence dependent on the magnitude of the time interval. If the sediment transport is constant, i.e. if the slope of the curve is a constant, the time interval is the total duration of the run, e.g. 30 minutes. For varying sediment transport the accuracy is decreasing rapidly. Furthermore, the erosion process was sometimes intermittent so that the bed load was stepwise increasing. Since the error on the cumulated bed load is less than $1 \%$, the bed load transport can be rather accurately calculated; the error will remain less than $10 \%$. 
The suspended sediment transport creates more worries. Suspended load transport is calculated as the difference in suspended solids concentrations measured downstream and upstream of the sediment bed multiplied by the discharge. Because of the significant errors on the determination of suspension concentrations, around $30 \%$, the error on the difference between the two concentration values is already $60 \%$. Combined with the errors on the discharge measurement, the total error can go up to $\mathbf{1 0 0} \%$. The measured suspended load transport is hence not very reliable.

\section{A2.9 Erosion rate}

Erosion rates are by definition the sediment transport divided by the sediment area. This area is well-known since it is determined by the sediment box dimensions. Calculating the erosion rates for both suspended and bed load does not induce extra inaccuracies. The relative errors remain the same. The total erosion rate is the sum of bed load and suspended load erosion. In most experiments the bed load transport was dominant and the suspended load, with its inaccuracies, could be neglected. For the experiments on low density, layered beds the suspended load was as important as the bed load. In that case the total erosion rates are not accurate.

\section{A2.10 Bed shear stress}

The bed shear stresses mentioned in this work are calculated using a side wall elimination technique $\left(\tau_{b}=\rho g R_{b} S_{e}\right.$, Appendix 1). Only when studying the shear stress distribution over the cross section (Chapter 5) the shear stresses were calculated from the velocity profile. The side wall elimination method was chosen because it is a lot less sensitive to inaccuracies of the bed level and hence the water level. When dealing with erosion these inaccuracies are significant (see $\S 3.7 .3)$.

In $\S 3.7 .3$ the effect of errors of the water level was already discussed. For a change in the water level of $2 \mathrm{~mm}$, the shear stress $\left(\tau=\rho u_{*}{ }^{2}\right)$ changes with $2 \%$, via the changes in the calculated hydraulic radius of the bed. 
Above, it was shown that the errors on the slope of the energy line are about $15 \%$. Combining both effects the error on the bed shear stress can go up to $25 \%$ for small bed shear stresses.

By definition the critical shear stress for erosion is calculated as the the average of the bed shear stresses ( $\$ 4.3 .3$ ): the values before and after the onset of erosion. The accuracy of the critical shear stress is hence a function of the discharge interval. This means that in some cases the percentage error may be well over $50 \%$, although in most cases this error varied between $30 \%$ and $50 \%$. 


\section{Appendix 3: \\ Experimental data}

In this appendix an overview is given of the results of the erosion experiments on both homogeneous and layered sand/mud mixtures.

The used notations are:

Run No the name en number of the experiment

\%fines [\%] the amount of fines in the mixture, i.e. the percentage by weight smaller than $63 \mu \mathrm{m}$

$S_{0} \quad[-] \quad$ the bottom slope of the flume

Q $[1 / s] \quad$ the discharge, averaged over the duration of the experiment

$\mathrm{H} \quad[\mathrm{m}]$ the time averaged water level, mean of the water level upstream and the water level downstream of the measuring section

$\mathrm{V}[\mathrm{m} / \mathrm{s}]$ the time averaged longitudinal mean velocity

E $\left[\mathrm{kg} / \mathrm{sm}^{2}\right]$ the erosion rate, total of suspended load and bed load transport

For the experiments on layered beds the initial erosion rate, immediately after an increase of the discharge, is given.

$\tau_{\mathrm{b}}$

[Pa] the time averaged bed shear stress, calculated using a side wall elimination technique (see Appendix 1). For the experiments with sand or cohesionless mixtures the grain shear stresses are listed. 
A3.1 Preliminary experiments on sand beds.

\begin{tabular}{l|r|r|r|r|r|r|r}
\hline \hline Run No & \%fines & So & $\mathrm{Q}$ & $\mathrm{H}$ & $\mathrm{V}$ & $\mathrm{E}$ & $\tau_{\mathrm{b}}$ \\
\hline $\mathrm{H} 21$ & 0 & 0.0032 & 22.7 & 0.092 & 0.615 & 0.00948 & 1.410 \\
$\mathrm{H} 22$ & 0 & 0.0032 & 25.4 & 0.096 & 0.663 & 0.01121 & 1.593 \\
$\mathrm{H} 23$ & 0 & 0.0032 & 15.5 & 0.072 & 0.537 & 0.00517 & 1.088 \\
$\mathrm{G} 01$ & 0 & 0.0045 & 24.0 & 0.131 & 0.458 & 0.00190 & 0.750 \\
$\mathrm{G} 02$ & 0 & 0.0045 & 31.0 & 0.153 & 0.508 & 0.00181 & 0.781 \\
G03 & 0 & 0.0045 & 36.0 & 0.177 & 0.509 & 0.00138 & 0.750 \\
G04 & 0 & 0.0045 & 42.8 & 0.194 & 0.551 & 0.00164 & 0.695 \\
G05 & 0 & 0.0045 & 45.0 & 0.204 & 0.551 & 0.00190 & 0.653 \\
G51 & 0 & 0.0037 & 18.1 & 0.155 & 0.291 & 0.00009 & 0.365 \\
G52 & 0 & 0.0037 & 24.2 & 0.162 & 0.374 & 0.00069 & 0.532 \\
G53 & 0 & 0.0037 & 31.3 & 0.156 & 0.500 & 0.00500 & 0.824 \\
\hline
\end{tabular}


A3.2 Erosion of homogeneous montmorillonite mixtures.

A3.2.1 High density $\left(1850 \mathrm{~kg} / \mathrm{m}^{3}\right)$

\begin{tabular}{|c|c|c|c|c|c|c|c|}
\hline Run No & \%fines & So & $\mathrm{Q}$ & $\overline{\mathrm{H}}$ & $\overline{\mathrm{V}}$ & $\bar{E}$ & $\tau_{b}$ \\
\hline G11 & 4.3 & 0.0045 & 23.6 & 0.149 & 0.396 & 0.00043 & 0.607 \\
\hline G12 & 4.3 & 0.0045 & 31.2 & 0.163 & 0.477 & 0.00198 & 0.804 \\
\hline G13 & 4.3 & 0.0045 & 35.8 & 0.171 & 0.524 & 0.00293 & 0.890 \\
\hline G14 & 4.3 & 0.0045 & 41.9 & 0.191 & 0.550 & 0.00207 & 0.819 \\
\hline G15 & 4.3 & 0.0045 & 45.0 & 0.208 & 0.542 & 0.00121 & 0.666 \\
\hline G21 & 7 & 0.0045 & 21.9 & 0.139 & 0.396 & 0.00000 & 0.000 \\
\hline $\mathrm{G} 22$ & 7 & 0.0045 & 32.0 & 0.147 & 0.543 & 0.00190 & 1.061 \\
\hline $\mathrm{G} 23$ & 7 & 0.0045 & 36.6 & 0.150 & 0.612 & 0.00431 & 1.206 \\
\hline G24 & 7 & 0.0045 & 39.6 & 0.191 & 0.517 & 0.00052 & 0.815 \\
\hline G25 & 7 & 0.0045 & 43.7 & 0.193 & 0.565 & 0.00095 & 0.908 \\
\hline $\mathrm{H} 41$ & 6 & 0.0032 & 14.8 & 0.062 & 0.597 & 0.00190 & 1.176 \\
\hline $\mathrm{H} 42$ & 6 & 0.0032 & 21.3 & 0.088 & 0.605 & 0.00310 & 1.020 \\
\hline $\mathrm{H} 43$ & 6 & 0.0032 & 16.3 & 0.077 & 0.529 & 0.00121 & 0.733 \\
\hline $\mathrm{H} 44$ & 6 & 0.0032 & 15.8 & 0.081 & 0.488 & 0.00129 & 0.655 \\
\hline $\mathrm{H} 45$ & 6 & 0.0032 & 19.9 & 0.090 & 0.553 & 0.00103 & 0.681 \\
\hline G41 & 9 & 0.0037 & 26.5 & 0.136 & 0.487 & 0.00000 & 0.648 \\
\hline G42 & 9 & 0.0037 & 32.6 & 0.141 & 0.578 & 0.00069 & 0.914 \\
\hline G43 & 9. & 0.0037 & 37.1 & 0.142 & 0.652 & 0.00112 & 1.023 \\
\hline G44 & 9 & 0.0037 & 42.3 & 0.144 & 0.735 & 0.00121 & 1.045 \\
\hline G45 & 9 & 0.0037 & 43.9 & 0.138 & 0.795 & 0.00103 & 0.000 \\
\hline H9 1 & 9.4 & 0.00205 & 11.5 & 0.057 & 0.504 & 0.00233 & 0.827 \\
\hline $\mathrm{H} 92$ & 9.4 & 0.00205 & 15.2 & 0.068 & 0.560 & 0.00216 & 0.943 \\
\hline G61 & 11 & 0.003 & 20.4 & 0.175 & 0.291 & 0.00000 & 0.199 \\
\hline G62 & 11 & 0.003 & 26.0 & 0.162 & 0.401 & 0.00000 & 0.372 \\
\hline G63 & 11 & 0.003 & 31.5 & 0.159 & 0.495 & 0.00043 & 0.553 \\
\hline G64 & 11 & 0.003 & 38.3 & 0.161 & 0.595 & 0.00069 & 0.876 \\
\hline G65 & 11 & 0.003 & 43.4 & 0.150 & 0.733 & 0.00181 & 1.414 \\
\hline $\mathrm{H} 11$ & 12 & 0.00345 & 26.2 & 0.182 & 0.360 & 0.00009 & 0.783 \\
\hline $\mathrm{H} 12$ & 12 & 0.00345 & 40.9 & 0.183 & 0.559 & 0.00043 & 1.238 \\
\hline $\mathrm{H} 13$ & 12 & 0.00345 & 61.6 & 0.182 & 0.846 & 0.00052 & 2.189 \\
\hline G31 & 13.6 & 0.0045 & 21.4 & 0.168 & 0.318 & 0.00000 & 1.315 \\
\hline G32 & 13.6 & 0.0045 & 29.6 & 0.164 & 0.451 & 0.00052 & 1.812 \\
\hline G33 & 13.6 & 0.0045 & 35.5 & 0.198 & 0.448 & 0.00009 & 1.647 \\
\hline G34 & 13.6 & 0.0045 & 40.9 & 0.215 & 0.476 & 0.00017 & 1.328 \\
\hline G35 & 13.6 & 0.0045 & 43.5 & 0.204 & 0.533 & 0.00043 & 1.855 \\
\hline
\end{tabular}




\begin{tabular}{|c|c|c|c|c|c|c|c|}
\hline Run No & \%fines & So & $\mathrm{Q}$ & $\mathrm{H}$ & $\mathrm{V}$ & $\bar{E}$ & $\overline{\tau_{b}}$ \\
\hline $\mathrm{H} 101$ & 14.4 & 0.00205 & 12.8 & 0.057 & 0.561 & 0.00164 & 1.179 \\
\hline $\mathrm{H} 102$ & 14.4 & 0.00205 & 15.1 & 0.063 & 0.599 & 0.00095 & 1.091 \\
\hline $\mathrm{H} 103$ & 14.4 & 0.00205 & 18.8 & 0.075 & 0.627 & 0.00095 & 0.991 \\
\hline $\mathrm{R} 24$ & 18 & 0.0002 & 20.0 & 0.220 & 0.230 & 0.00000 & 2.397 \\
\hline R25 & 18 & 0.0002 & 25.0 & 0.230 & 0.260 & 0.00000 & 2.465 \\
\hline R26 & 18 & 0.0002 & 36.0 & 0.230 & 0.390 & 0.00000 & 2.265 \\
\hline $\mathrm{R} 27$ & 18 & 0.0002 & 41.0 & 0.220 & 0.480 & 0.00034 & 2.012 \\
\hline R28 & 18 & 0.0002 & 43.0 & 0.200 & 0.550 & 0.00095 & 2.273 \\
\hline R30 & 20 & 0.0012 & 23.0 & 0.160 & 0.380 & 0.00000 & 2.064 \\
\hline R31 & 20 & 0.0012 & 34.0 & 0.180 & 0.470 & 0.00009 & 3.119 \\
\hline R32 & 20 & 0.0012 & 45.0 & 0.200 & 0.560 & 0.00060 & 2.290 \\
\hline R33 & 20 & 0.0012 & 46.0 & 0.240 & 0.480 & 0.00009 & 0.419 \\
\hline R34 & 20 & 0.0012 & 33.0 & 0.170 & 0.490 & 0.00009 & 1.026 \\
\hline R35 & 20 & 0.0012 & 40.0 & 0.190 & 0.530 & 0.00026 & 1.225 \\
\hline H31 & 21.7 & 0.0037 & 21.3 & 0.128 & 0.416 & 0.00000 & 0.000 \\
\hline H32 & 21.7 & 0.0037 & 18.3 & 0.083 & 0.551 & 0.00026 & 1.886 \\
\hline H33 & 21.7 & 0.0037 & 21.6 & 0.092 & 0.587 & 0.00052 & 1.695 \\
\hline $\mathrm{H} 34$ & 21.7 & 0.0037 & 28.0 & 0.106 & 0.660 & 0.00052 & 1.538 \\
\hline $\mathrm{H} 35$ & 21.7 & 0.0037 & 35.2 & 0.122 & 0.721 & 0.00043 & 1.429 \\
\hline H36 & 21.7 & 0.0037 & 42.6 & 0.138 & 0.772 & 0.00026 & 1.135 \\
\hline H51 & 22 & 0.0037 & 18.3 & 0.086 & 0.532 & 0.00147 & 1.737 \\
\hline H52 & 22 & 0.0037 & 23.8 & 0.099 & 0.601 & 0.00103 & 1.167 \\
\hline H53 & 22 & 0.0037 & 31.3 & 0.116 & 0.675 & 0.00069 & 0.724 \\
\hline H6I & 24 & 0.0037 & 15.8 & 0.072 & 0.549 & 0.00069 & 1.369 \\
\hline H62 & 24 & 0.0037 & 23.3 & 0.092 & 0.633 & 0.00078 & 1.459 \\
\hline H63 & 24 & 0.0037 & 30.0 & 0.109 & 0.688 & 0.00052 & 1.140 \\
\hline R36 & 25 & 0.0002 & 29.0 & 0.170 & 0.420 & 0.00000 & 1.636 \\
\hline R37 & 25 & 0.0002 & 41.0 & 0.230 & 0.450 & 0.00009 & 2.159 \\
\hline R38 & 25 & 0.0002 & 45.0 & 0.190 & 0.600 & 0.00060 & 3.326 \\
\hline R39 & 25 & 0.0002 & 44.0 & 0.190 & 0.580 & 0.00034 & 2.107 \\
\hline R45 & 28 & 0.0022 & 29.0 & 0.170 & 0.430 & 0.00000 & 1.429 \\
\hline R46 & 28 & 0.0022 & 39.7 & 0.180 & 0.560 & 0.00009 & 2.245 \\
\hline 848 & 28 & 0.0022 & 49.3 & 0.170 & 0.720 & 0.00012 & 0.654 \\
\hline
\end{tabular}


A3.2.2 Low density $\left(1650 \mathrm{~kg} / \mathrm{m}^{3}\right)$

\begin{tabular}{l|r|r|r|r|r|r|r}
\hline \hline Run No & \%fines & $\mathrm{S}_{\mathrm{o}}$ & $\mathrm{Q}$ & $\mathrm{H}$ & $\mathrm{V}$ & $\mathrm{E}$ & $\tau_{\mathrm{b}}$ \\
\hline E41 & 6.5 & 0.0029 & 3.6 & 0.037 & 0.248 & 0.00000 & 0.875 \\
E41 & 6.5 & 0.0029 & 10.2 & 0.059 & 0.430 & 0.00023 & 1.433 \\
E42 & 6.5 & 0.0029 & 14.8 & 0.074 & 0.502 & 0.00076 & 1.786 \\
E43 & 6.5 & 0.0029 & 19.0 & 0.085 & 0.558 & 0.00144 & 1.891 \\
E44 & 6.5 & 0.0029 & 25.2 & 0.101 & 0.625 & 0.00217 & 1.841 \\
E51 & 20.1 & 0.0029 & 2.4 & 0.031 & 0.195 & 0.00000 & 0.571 \\
E51 & 20.1 & 0.0029 & 7.5 & 0.049 & 0.382 & 0.00000 & 0.952 \\
E52 & 20.1 & 0.0029 & 12.8 & 0.066 & 0.485 & 0.00003 & 1.343 \\
E52 & 20.1 & 0.0029 & 17.8 & 0.079 & 0.558 & 0.00004 & 1.814 \\
E53 & 20.1 & 0.0029 & 22.4 & 0.091 & 0.618 & 0.00009 & 2.155 \\
E53 & 20.1 & 0.0029 & 29.8 & 0.108 & 0.687 & 0.00041 & 2.616 \\
E54 & 20.1 & 0.0029 & 37.0 & 0.124 & 0.746 & 0.00071 & 3.266 \\
E55 & 20.1 & 0.0029 & 41.1 & 0.134 & 0.766 & 0.00025 & 3.519 \\
E55 & 20.1 & 0.0029 & 46.4 & 0.143 & 0.809 & 0.00026 & 3.486 \\
E61 & 15.9 & 0.0029 & 6.1 & 0.043 & 0.351 & 0.00000 & 0.433 \\
E61 & 15.9 & 0.0029 & 10.1 & 0.056 & 0.451 & 0.00000 & 0.663 \\
E62 & 15.9 & 0.0029 & 16.1 & 0.074 & 0.546 & 0.00000 & 0.882 \\
E62 & 15.9 & 0.0029 & 22.7 & 0.090 & 0.631 & 0.00014 & 1.213 \\
E63 & 15.9 & 0.0029 & 29.4 & 0.106 & 0.693 & 0.00065 & 1.612 \\
E64 & 15.9 & 0.0029 & 35.3 & 0.119 & 0.742 & 0.00281 & 1.606 \\
\hline
\end{tabular}


A3.3 Erosion of homogeneous kaolinite mixtures.

A3.3.1 High density $\left(1850 \mathrm{~kg} / \mathrm{m}^{3}\right)$

\begin{tabular}{|c|c|c|c|c|c|c|c|}
\hline Run No & \%fines & So & Q & $\mathrm{H}$ & $\mathrm{V}$ & $\bar{E}$ & $\overline{\tau_{b}}$ \\
\hline A90 & 3 & 0.0033 & 4.4 & 0.034 & 0.318 & 0.00195 & 0.505 \\
\hline A93 & 3 & 0.0033 & 6.6 & 0.043 & 0.389 & 0.00214 & 0.657 \\
\hline A91 & 3 & 0.0033 & 7.4 & 0.045 & 0.415 & 0.00417 & 0.750 \\
\hline A92 & 3 & 0.0033 & 11.6 & 0.057 & 0.509 & 0.00544 & 1.002 \\
\hline J11 & 3.8 & 0.005 & 8 & 0.045 & 0.444 & 0.00414 & 2.862 \\
\hline $\mathrm{A} 30$ & 4.2 & 0.0035 & 6.3 & 0.059 & 0.268 & 0.00066 & 5.181 \\
\hline $\mathrm{A} 40$ & 4.2 & 0.0035 & 7.2 & 0.053 & 0.334 & 0.00067 & 1.290 \\
\hline A 31 & 4.2 & 0.0035 & 9.5 & 0.063 & 0.379 & 0.00149 & 5.421 \\
\hline A41 & 4.2 & 0.0035 & 9.9 & 0.060 & 0.411 & 0.00083 & 1.899 \\
\hline A 42 & 4.2 & 0.0035 & 12.9 & 0.070 & 0.462 & 0.00151 & 2.068 \\
\hline A 32 & 4.2 & 0.0035 & 13.0 & 0.055 & 0.586 & 0.00154 & 3.084 \\
\hline A 33 & 4.2 & 0.0035 & 15.8 & 0.080 & 0.493 & 0.00168 & 2.143 \\
\hline A43 & 4.2 & 0.0035 & 17.6 & 0.083 & 0.531 & 0.00284 & 2.428 \\
\hline A44 & 4.2 & 0.0035 & 23.2 & 0.097 & 0.597 & 0.00364 & 2.541 \\
\hline A45 & 4.2 & 0.0035 & 30.4 & 0.116 & 0.659 & 0.00538 & 2.907 \\
\hline A46 & 4.2 & 0.0035 & 33.1 & 0.122 & 0.679 & 0.00611 & 2.618 \\
\hline K11 & 4.7 & 0.00205 & 8.8 & 0.048 & 0.456 & 0.00267 & 1.136 \\
\hline $\mathrm{K} 12$ & 4.7 & 0.00205 & 12.6 & 0.061 & 0.516 & 0.00293 & 0.827 \\
\hline K13 & 4.7 & 0.00205 & 14.5 & 0.072 & 0.505 & 0.00293 & 0.848 \\
\hline $\mathrm{J} 22$ & 5.7 & 0.005 & 5.9 & 0.037 & 0.399 & 0.00405 & 1.706 \\
\hline $\mathrm{J} 23$ & 5.7 & 0.005 & 7.2 & 0.041 & 0.439 & 0.00388 & 1.574 \\
\hline $\mathrm{X} 21$ & 6.2 & 0.0035 & 5.2 & 0.041 & 0.315 & 0.00016 & 1.052 \\
\hline$X 22$ & 6.2 & 0.0035 & 11.5 & 0.060 & 0.483 & 0.00103 & 1.419 \\
\hline$X 23$ & 6.2 & 0.0035 & 14.1 & 0.068 & 0.519 & 0.00172 & 1.271 \\
\hline X24 & 6.2 & 0.0035 & 19.1 & 0.081 & 0.586 & 0.00222 & 1.188 \\
\hline$\times 25$ & 6.2 & 0.0035 & 24.5 & 0.095 & 0.646 & 0.00269 & 0.698 \\
\hline $\mathrm{K} 21$ & 7.1 & 0.00205 & 10.7 & 0.051 & 0.526 & 0.00121 & 0.832 \\
\hline $\mathrm{K} 22$ & 7.1 & 0.00205 & 15.7 & 0.069 & 0.569 & 0.00103 & 0.771 \\
\hline $\mathrm{K} 23$ & 7.1 & 0.00205 & 20.3 & 0.087 & 0.583 & 0.00172 & 0.717 \\
\hline A50 & 8.2 & 0.0035 & 13.6 & 0.071 & 0.479 & 0.00046 & 1.148 \\
\hline A52 & 8.2 & 0.0035 & 14.3 & 0.095 & 0.374 & 0.00154 & 8.105 \\
\hline A10 & 9.5 & 0.0035 & 4 & 0.099 & 0.101 & 0.00000 & 2.499 \\
\hline A11 & 9.5 & 0.0035 & 8.4 & 0.096 & 0.220 & 0.00000 & 2.444 \\
\hline A12 & 9.5 & 0.0035 & 10.5 & 0.098 & 0.270 & 0.00000 & 2.510 \\
\hline A13 & 9.5 & 0.0035 & 11.8 & 0.088 & 0.338 & 0.00000 & 2.331 \\
\hline
\end{tabular}




\begin{tabular}{|c|c|c|c|c|c|c|c|}
\hline Run No & \%fines & So & $\overline{Q Q}$ & $\mathrm{H}$ & $\overline{\mathrm{V}}$ & $\bar{E}$ & $\tau_{b}$ \\
\hline A15 & 9.5 & 0.0035 & 17.6 & 0.080 & 0.550 & 0.00062 & 2.192 \\
\hline A16 & 9.5 & 0.0035 & 18.9 & 0.108 & 0.438 & 0.00017 & 2.837 \\
\hline $\mathrm{A} 20$ & 9.5 & 0.0035 & 20.2 & 0.083 & 0.610 & 0.00159 & 2.250 \\
\hline $\mathrm{A} 21$ & 9.5 & 0.0035 & 30.3 & 0.111 & 0.682 & 0.00203 & 2.010 \\
\hline A22 & 9.5 & 0.0035 & 36.2 & 0.112 & 0.810 & 0.00387 & 2.167 \\
\hline A23 & 9.5 & 0.0035 & 40.1 & 0.119 & 0.839 & 0.00397 & 2.139 \\
\hline $\mathrm{A} 24$ & 9.5 & 0.0035 & 44.1 & 0.144 & 0.764 & 0.00265 & 2.525 \\
\hline A70 & 9.8 & 0.0035 & 22.8 & 0.088 & 0.647 & 0.00351 & 2.038 \\
\hline A71 & 9.8 & 0.0035 & 26.1 & 0.097 & 0.672 & 0.00145 & 1.955 \\
\hline A72 & 9.8 & 0.0035 & 29.7 & 0.104 & 0.713 & 0.00147 & 1.885 \\
\hline A73 & 9.8 & 0.0035 & 34.2 & 0.114 & 0.753 & 0.00144 & 1.877 \\
\hline $\mathrm{A} 01$ & 10.1 & 0.00595 & 5.9 & 0.043 & 0.344 & 0.00758 & 2.405 \\
\hline $\mathrm{A} 02$ & 10.1 & 0.00595 & 9.98 & 0.049 & 0.511 & 0.00956 & 2.484 \\
\hline $\mathrm{A} 03$ & 10.1 & 0.00595 & 12.9 & 0.054 & 0.060 & 0.00800 & 2.628 \\
\hline $\mathrm{A} 04$ & 10.1 & 0.00595 & 15.7 & 0.065 & 0.602 & 0.00603 & 2.293 \\
\hline A05 & 10.1 & 0.00595 & 19.1 & 0.069 & 0.655 & 0.00553 & 2.500 \\
\hline A06 & 10.1 & 0.00595 & 19.8 & 0.074 & 0.670 & 0.00526 & 2.540 \\
\hline $\mathrm{J} 31$ & 11.1 & 0.005 & 4.7 & 0.036 & 0.326 & 0.00086 & 1.312 \\
\hline $\mathrm{J} 32$ & 11.1 & 0.005 & 7.3 & 0.047 & 0.388 & 0.00060 & 1.142 \\
\hline $\mathrm{J} 33$ & 11.1 & 0.005 & 8.6 & 0.053 & 0.406 & 0.00043 & 1.023 \\
\hline $\mathrm{X} 11$ & 11.1 & 0.0035 & 9.9 & 0.056 & 0.442 & 0.00084 & 0.317 \\
\hline J34 & 11.1 & 0.005 & 11.6 & 0.063 & 0.460 & 0.00073 & 1.007 \\
\hline $\mathrm{J} 35$ & 11.1 & 0.005 & 17.9 & 0.075 & 0.597 & 0.00063 & 1.173 \\
\hline $\mathrm{X} 12$ & 11.1 & 0.0035 & 18.0 & 0.079 & 0.570 & 0.00139 & 1.095 \\
\hline $\mathrm{X} 13$ & 11.1 & 0.0035 & 22.1 & 0.088 & 0.628 & 0.00149 & 1.264 \\
\hline A 60 & 12.4 & 0.0035 & 13.7 & 0.074 & 0.464 & 0.00000 & 2.242 \\
\hline A61 & 12.4 & 0.0035 & 21.0 & 0.092 & 0.570 & 0.00045 & 2.732 \\
\hline A62 & 12.4 & 0.0035 & 26.8 & 0.107 & 0.628 & 0.00043 & 3.261 \\
\hline A63 & 12.4 & 0.0035 & 30.7 & 0.114 & 0.672 & 0.00000 & 3.294 \\
\hline A64 & 12.4 & 0.0035 & 52.4 & 0.159 & 0.824 & 0.00075 & 2.191 \\
\hline A65 & 12.4 & 0.0035 & 56.5 & 0.165 & 0.856 & 0.00116 & 2.754 \\
\hline A66 & 12.4 & 0.0035 & 60.1 & 0.172 & 0.904 & 0.00098 & 3.480 \\
\hline A67 & 12.4 & 0.0035 & 67.1 & 0.180 & 0.934 & 0.00134 & 4.440 \\
\hline A68 & 12.4 & 0.0035 & 70.9 & 0.185 & 0.956 & 0.00147 & 4.700 \\
\hline A 69 & 12.4 & 0.0035 & 76.4 & 0.194 & 0.987 & 0.00123 & 4.587 \\
\hline K31 & 14.9 & 0.00205 & 11.2 & 0.056 & 0.501 & 0.00207 & 0.189 \\
\hline $\mathrm{K} 32$ & 14.9 & 0.00205 & 15.5 & 0.077 & 0.503 & 0.00103 & 0.052 \\
\hline K33 & 14.9 & 0.00205 & 20.5 & 0.096 & 0.534 & 0.00086 & 0.300 \\
\hline
\end{tabular}


A3.3.2 Low density $\left(1650 \mathrm{~kg} / \mathrm{m}^{3}\right)$

\begin{tabular}{l|r|r|r|r|r|r|r}
\hline \hline Run No & \%fines & $\mathrm{S}_{\mathrm{o}}$ & $\mathrm{Q}$ & $\mathrm{H}$ & $\mathrm{V}$ & $\mathrm{E}$ & $\tau_{\mathrm{b}}$ \\
\hline E11 & 11.3 & 0.0029 & 4.4 & 0.088 & 0.125 & 0.00000 & 0.314 \\
E11 & 11.3 & 0.0029 & 4.3 & 0.038 & 0.283 & 0.00000 & 0.509 \\
E12 & 11.3 & 0.0029 & 12.5 & 0.064 & 0.486 & 0.00000 & 0.889 \\
E13 & 11.3 & 0.0029 & 17.6 & 0.078 & 0.561 & 0.00002 & 1.137 \\
E14 & 11.3 & 0.0029 & 22.7 & 0.091 & 0.623 & 0.00012 & 1.411 \\
E15 & 11.3 & 0.0029 & 30.6 & 0.110 & 0.692 & 0.00049 & 1.485 \\
E21 & 15.8 & 0.0029 & 14.3 & 0.070 & 0.513 & 0.00000 & 0.439 \\
E22 & 15.8 & 0.0029 & 18.9 & 0.081 & 0.581 & 0.00000 & 0.816 \\
E23 & 15.8 & 0.0029 & 34.9 & 0.117 & 0.747 & 0.00023 & 1.786 \\
E23 & 15.8 & 0.0029 & 39.6 & 0.126 & 0.783 & 0.00031 & 1.840 \\
E24 & 15.8 & 0.0029 & 43.5 & 0.135 & 0.808 & 0.00050 & 1.804 \\
E31 & 15.7 & 0.0029 & 2.9 & 0.096 & 0.076 & 0.00000 & 0.908 \\
E31 & 15.7 & 0.0029 & 2.9 & 0.029 & 0.248 & 0.00000 & 0.558 \\
E32 & 15.7 & 0.0029 & 6.8 & 0.043 & 0.392 & 0.00000 & 0.890 \\
E32 & 15.7 & 0.0029 & 12.5 & 0.060 & 0.522 & 0.00000 & 1.259 \\
E32 & 15.7 & 0.0029 & 17.5 & 0.073 & 0.596 & 0.00000 & 1.570 \\
E32 & 15.7 & 0.0029 & 22.9 & 0.087 & 0.661 & 0.00000 & 1.843 \\
E33 & 15.7 & 0.0029 & 32.7 & 0.109 & 0.753 & 0.00000 & 2.374 \\
E33 & 15.7 & 0.0029 & 42.1 & 0.124 & 0.851 & 0.00017 & 2.699 \\
E34 & 15.7 & 0.0029 & 46.9 & 0.137 & 0.858 & 0.00018 & 2.804 \\
E34 & 15.7 & 0.0029 & 55.2 & 0.153 & 0.900 & 0.00021 & 2.935 \\
E34 & 15.7 & 0.0029 & 61.6 & 0.163 & 0.942 & 0.00029 & 3.158 \\
E34 & 15.7 & 0.0029 & 68.6 & 0.175 & 0.282 & 0.00037 & 2.974 \\
\hline
\end{tabular}


A3.4 Erosion of homogeneous mud mixtures.

A3.4.1 Mud1 mixtures.

\begin{tabular}{l|r|r|r|r|r|r|r}
\hline \hline Run No & \%fines & $\mathrm{S}_{\mathrm{o}}$ & $\mathrm{Q}$ & $\mathrm{H}$ & $\mathrm{V}$ & $\mathrm{E}$ & $\tau_{\mathrm{b}}$ \\
\hline M01 & 6.2 & 0.0035 & 3.3 & 0.037 & 0.220 & 0.00000 & 1.364 \\
M02 & 6.2 & 0.0035 & 7.4 & 0.051 & 0.366 & 0.00019 & 1.931 \\
M03 & 6.2 & 0.0035 & 11.8 & 0.063 & 0.467 & 0.00093 & 1.784 \\
M04 & 6.2 & 0.0035 & 14.1 & 0.070 & 0.502 & 0.00115 & 1.853 \\
M05 & 6.2 & 0.0035 & 20.9 & 0.088 & 0.598 & 0.00171 & 1.876 \\
M11 & 10.3 & 0.0035 & 1.9 & 0.037 & 0.128 & 0.00000 & 0.028 \\
M12 & 10.3 & 0.0035 & 7.4 & 0.054 & 0.345 & 0.00000 & 0.750 \\
M13 & 10.3 & 0.0035 & 12.4 & 0.066 & 0.469 & 0.00017 & 1.808 \\
M14 & 10.3 & 0.0035 & 15.2 & 0.073 & 0.519 & 0.00034 & 1.973 \\
M15 & 10.3 & 0.0035 & 19.8 & 0.084 & 0.588 & 0.00067 & 2.212 \\
M16 & 10.3 & 0.0035 & 24.6 & 0.096 & 0.643 & 0.00095 & 2.359 \\
\hline \hline
\end{tabular}


A3.4.2 Mud2 mixtures.

\begin{tabular}{|c|c|c|c|c|c|c|c|}
\hline Run No & \%fines & $\mathrm{S}_{0}$ & Q & $\mathrm{H}$ & $\mathrm{V}$ & $\mathrm{E}$ & $\tau_{b}$ \\
\hline B53 & 3.3 & 0.0035 & 3.7 & 0.048 & 0.194 & 0.00037 & 1.089 \\
\hline B54 & 3.3 & 0.0035 & 7.7 & 0.061 & 0.317 & 0.00222 & 0.703 \\
\hline B50 & 3.3 & 0.0035 & 9.2 & 0.076 & 0.304 & 0.00473 & 2.621 \\
\hline B51 & 3.3 & 0.0035 & 11.9 & 0.069 & 0.427 & 0.00553 & 0.963 \\
\hline B52 & 3.3 & 0.0035 & 13.0 & 0.075 & 0.433 & 0.00494 & 0.579 \\
\hline B21 & 5.3 & 0.0035 & 11.2 & 0.051 & 0.545 & 0.00253 & 1.684 \\
\hline $\mathrm{B} 22$ & 5.3 & 0.0035 & 12.7 & 0.054 & 0.590 & 0.00317 & 2.249 \\
\hline $\mathrm{B} 23$ & 5.3 & 0.0035 & 15.8 & 0.058 & 0.684 & 0.00560 & 4.014 \\
\hline $\mathrm{B} 10$ & 9.3 & 0.0035 & 6.3 & 0.044 & 0.354 & 0.00000 & 1.672 \\
\hline B11 & 9.3 & 0.0035 & 8.8 & 0.057 & 0.372 & 0.00000 & 2.648 \\
\hline $\mathrm{B} 12$ & 9.3 & 0.0035 & 11.0 & 0.063 & 0.437 & 0.00041 & 3.212 \\
\hline B13 & 9.3 & 0.0035 & 13.5 & 0.069 & 0.487 & 0.00152 & 3.821 \\
\hline B 14 & 9.3 & 0.0035 & 16.6 & 0.077 & 0.538 & 0.00284 & 4.253 \\
\hline $\mathrm{B} 15$ & 9.3 & 0.0035 & 18.0 & 0.081 & 0.554 & 0.00270 & 4.394 \\
\hline $\mathrm{B} 30$ & 10.8 & 0.0035 & 10.2 & 0.052 & 0.489 & 0.00000 & 0.653 \\
\hline B31 & 10.8 & 0.0035 & 13.4 & 0.062 & 0.540 & 0.00046 & 0.849 \\
\hline B32 & 10.8 & 0.0035 & 16.5 & 0.071 & 0.579 & 0.00137 & 1.168 \\
\hline B33 & 10.8 & 0.0035 & 18.6 & 0.077 & 0.604 & 0.00295 & 1.212 \\
\hline B34 & 10.8 & 0.0035 & 21.3 & 0.085 & 0.627 & 0.00455 & 1.143 \\
\hline B40 & 13.7 & 0.0035 & 10.8 & 0.060 & 0.453 & 0.00000 & 0.823 \\
\hline B41 & 13.7 & 0.0035 & 14.3 & 0.068 & 0.526 & 0.00092 & 0.848 \\
\hline B42 & 13.7 & 0.0035 & 17.6 & 0.078 & 0.566 & & 0.732 \\
\hline B43 & 13.7 & 0.0035 & 20.5 & 0.085 & 0.602 & 0.00017 & 0.616 \\
\hline$B 44$ & 13.7 & 0.0035 & 21.2 & 0.090 & 0.590 & 0.00041 & 0.770 \\
\hline
\end{tabular}


A3.5 Measured critical shear stresses for homogeneous mixtures.

\begin{tabular}{|c|c|c|c|c|c|c|}
\hline \%fines & Kaolinite & Montmorill. & Mud1 & Mud2 & $\begin{array}{l}\text { Kaolinite } \\
\text { Low density }\end{array}$ & $\begin{array}{l}\text { Montmorill. } \\
\text { Low density }\end{array}$ \\
\hline 3.3 & 0.400 & & & 0.200 & & \\
\hline 4.2 & 0.500 & & & & & \\
\hline 4.3 & & 0.540 & & & & \\
\hline 4.7 & 0.552 & & & & & \\
\hline 5.3 & & & & 1.290 & & \\
\hline 5.7 & 0.797 & & & & & \\
\hline 6.0 & & 0.484 & & & & \\
\hline 6.2 & 0.985 & & 1.577 & & & 1.217 \\
\hline 6.5 & & & & & & \\
\hline 7.0 & 1.139 & 0.707 & & & & \\
\hline 8.2 & 1.100 & & & & & \\
\hline 9.0 & & 0.656 & & & & \\
\hline 9.3 & & & & 1.790 & & \\
\hline 9.5 & 1.727 & & & & & \\
\hline 9.8 & 1.897 & & & & 1.478 & \\
\hline 10.1 & 1.900 & & & & & \\
\hline 10.3 & & & 1.645 & & & \\
\hline 10.8 & & & & 1.650 & & \\
\hline 11.0 & & 0.248 & & & & \\
\hline 11.1 & 2.118 & & & & 1.041 & \\
\hline 12.0 & & 0.699 & & & & \\
\hline 12.4 & 2.486 & & & & & \\
\hline 13.6 & & 1.298 & & 1.860 & & \\
\hline 14.4 & & 1.015 & & & & \\
\hline 14.9 & 3.048 & & & & & \\
\hline 15.7 & & & & & 1.466 & \\
\hline 15.8 & & & & & 2.278 & \\
\hline 15.9 & & & & & & 1.076 \\
\hline 20.0 & & 0.932 & & & & 1.340 \\
\hline 21.7 & & 1.090 & & & & \\
\hline 22.5 & & & & & 1.469 & \\
\hline 24.0 & & 1.101 & & & & \\
\hline 25.0 & & 1.688 & & & & \\
\hline 28.0 & & 1,837 & & & & \\
\hline
\end{tabular}

Remarks: 1. Critical shear stresses are expressed in $\mathrm{Pa}$.

2. The measured critical shear stress for sand only was $0.35 \mathrm{~Pa}$. 
A3.6 Erosion of layered mud/sand mixtures.

\begin{tabular}{l|r|r|r|r|r|r}
\hline \hline Run No & $\mathrm{S}_{\mathrm{o}}$ & $\mathrm{Q}$ & $\mathrm{H}$ & $\mathrm{V}$ & $\mathrm{E}$ & $\tau_{\mathrm{b}}$ \\
\hline $\mathrm{J} 11$ & 0.0029 & 3.6 & 0.169 & 0.053 & 0 & - \\
$\mathrm{J} 12$ & 0.0029 & 3.7 & 0.142 & 0.065 & 0 & - \\
$\mathrm{J} 13$ & 0.0029 & 5.0 & 0.148 & 0.084 & 0 & - \\
$\mathrm{J} 14$ & 0.0029 & 4.6 & 0.151 & 0.077 & 0 & - \\
$\mathrm{J} 15$ & 0.0029 & 4.6 & 0.115 & 0.099 & 0 & - \\
$\mathrm{J} 16$ & 0.0029 & 5.5 & 0.077 & 0.180 & 0.00004 & - \\
$\mathrm{J} 17$ & 0.0029 & 9.2 & 0.090 & 0.257 & 0.00052 & - \\
$\mathrm{J} 18$ & 0.0029 & 12.1 & 0.082 & 0.370 & 0.00077 & - \\
$\mathrm{J} 21$ & 0.0029 & 4.2 & 0.156 & 0.068 & 0 & 0.351 \\
$\mathrm{~J} 22$ & 0.0029 & 6.4 & 0.165 & 0.096 & 0 & 1.291 \\
$\mathrm{~J} 23$ & 0.0029 & 6.1 & 0.113 & 0.136 & 0.00117 & 0.790 \\
$\mathrm{~J} 24$ & 0.0029 & 7.0 & 0.096 & 0.184 & 0.00032 & 0.436 \\
$\mathrm{~J} 25$ & 0.0029 & 9.9 & 0.106 & 0.234 & 0.00139 & 0.713 \\
$\mathrm{~J} 26$ & 0.0029 & 12.4 & 0.114 & 0.272 & & 0.973 \\
$\mathrm{~J} 27$ & 0.0029 & 15.0 & 0.120 & 0.311 & 0.00118 & 0.654 \\
$\mathrm{~J} 28$ & 0.0029 & 15.0 & 0.089 & 0.420 & 0.00095 & 0.724 \\
$\mathrm{~J} 31$ & 0.0029 & 5.4 & 0.194 & 0.070 & 0 & 1.133 \\
$\mathrm{~J} 32$ & 0.0029 & 5.5 & 0.104 & 0.132 & 0.00109 & 0.739 \\
$\mathrm{~J} 33$ & 0.0029 & 8.2 & 0.080 & 0.256 & 0.00195 & 0.677 \\
$\mathrm{~J} 34$ & 0.0029 & 10.4 & 0.087 & 0.298 & 0.00029 & 0.921 \\
$\mathrm{~J} 35$ & 0.0029 & 13.8 & 0.097 & 0.356 & 0.00005 & 0.869 \\
$\mathrm{~J} 36$ & 0.0029 & 16.7 & 0.105 & 0.397 & 0.00075 & 0.769 \\
$\mathrm{~J} 37$ & 0.0029 & 20.6 & 0.094 & 0.551 & 0.00172 & 1.009 \\
$\mathrm{~J} 41$ & 0.0029 & 6.5 & 0.193 & 0.084 & 0 & 3.207 \\
$\mathrm{~J} 42$ & 0.0029 & 8.8 & 0.130 & 0.168 & 0.00197 & 2.087 \\
$\mathrm{~J} 43$ & 0.0029 & 12.3 & 0.121 & 0.254 & .0 .0036 & 2.024 \\
$\mathrm{~J} 44$ & 0.0029 & 15.5 & 0.127 & 0.305 & 0.00152 & 2.005 \\
$\mathrm{~J} 45$ & 0.0029 & 19.2 & 0.116 & 0.415 & 0.00321 & 1.803 \\
$\mathrm{~J} 46$ & 0.0029 & 21.6 & 0.126 & 0.427 & 0.0007 & 2.164 \\
$\mathrm{~J} 51$ & 0.0029 & 7.9 & 0.137 & 0.144 & 0.00144 & 2.345 \\
$\mathrm{~J} 52$ & 0.0029 & 14.1 & 0.116 & 0.306 & 0.00286 & 2.166 \\
$\mathrm{~J} 53$ & 0.0029 & 17.3 & 0.104 & 0.414 & 0.00191 & 1.785 \\
$\mathrm{~J} 54$ & 0.0029 & 22.9 & 0.108 & 0.531 & 0.00112 & 1.673 \\
$\mathrm{~J} 55$ & 0.0029 & 22.8 & 0.088 & 0.648 & 0.00166 & 1.422 \\
$\mathrm{~J} 61$ & 0.0029 & 7.3 & 0.117 & 0.124 & 0.00154 & 1.273 \\
$\mathrm{~J} 62$ & 0.0029 & 11.1 & 0.115 & 0.193 & 0.00097 & 1.517 \\
$\mathrm{~J} 63$ & 0.0029 & 14.8 & 0.121 & 0.245 & 0.00085 & 1.516
\end{tabular}




\begin{tabular}{|c|c|c|c|c|c|c|}
\hline Run No & $S_{0}$ & $\overline{\mathrm{Q}}$ & $\overline{\mathrm{H}}$ & $\overline{\mathrm{V}}$ & $\overline{\mathrm{E}}$ & $\overline{\tau_{b}}$ \\
\hline J64 & 0.0029 & 19.2 & 0.128 & 0.300 & 0.00119 & 1.182 \\
\hline $\mathrm{J} 65$ & 0.0029 & 20.7 & 0.100 & 0.416 & 0.00441 & 0.696 \\
\hline $\mathrm{J71}$ & 0.003 & 8.2 & 0.081 & 0.251 & 0 & 0.160 \\
\hline $\mathrm{J} 72$ & 0.003 & 13.5 & 0.076 & 0.442 & 0.00543 & 0.526 \\
\hline $\mathrm{J} 73$ & 0.003 & 16.9 & 0.099 & 0.424 & 0.00301 & 0.457 \\
\hline $\mathrm{J} 74$ & 0.003 & 19.4 & 0.096 & 0.506 & 0.00153 & 0.658 \\
\hline $\mathrm{J} 75$ & 0.003 & 25.3 & 0.116 & 0.546 & 0.00054 & 0.746 \\
\hline J81 & 0.003 & 8.8 & 0.117 & 0.189 & 0.00013 & 0.086 \\
\hline $\mathrm{J} 82$ & 0.003 & 13.1 & 0.100 & 0.327 & 0.00089 & 0.345 \\
\hline J83 & 0.003 & 18.5 & 0.098 & 0.471 & 0.00188 & 0.571 \\
\hline $\mathrm{J84}$ & 0.003 & 23.3 & 0.101 & 0.580 & 0.00246 & 0.900 \\
\hline
\end{tabular}




\section{Curriculum Vitae}

Hilde Maria TORFS was born in Mol in 1966. From 1984 until 1989 she studied Civil Engineering at the Katholieke Universiteit Leuven. The experimental work for her Master's thesis entitled "Erosiegedrag van zand-slib mengsels onder invloed van stroming" was carried out in the Laboratory of Fluid Mechanics of the Technische Universiteit Delft (the Netherlands) in the framework of the European ERASMUS student exchange programme.

Between October 1989 and October 1995 she worked at the Hydraulics Laboratory of the Katholieke Universiteit Leuven. From January 1989 until December 1994 she was the coordinator of an interuniversity research project funded by the Fund for Collective Fundamental Research (F.K.F.O.-project nr. 2.9012.90) about the erosion, sedimentation and resuspension of partly cohesive sediments. She also participated in Project 4: Cohesive Sediments of the MAST G8-M Coastal Morphodynamics research project financed by the Commission of the European Communities, Directorate General for Science, Research and Development. 


\section{List of relevant publications}

BERLAMONT J.E. and TORFS H.M. Modelling (partly) cohesive sediment transport in sewers. International Conference on Sewer Solids - Characterisation, Movements, Effect and Control, Dundee, September 1995, submitted for publication in I.A.W.Q. Water Science \& Technology.

BESTAWY A., TORFS $H$. and BERLAMONT J. Bed load transport by flood waves. Proceedings of the 6th International Conference on Civil and Structural Engineering Computing, Cambridge, August 28-30, 1995, pp. 249-254.

KABIR M.R. and TORFS H. Comparison of different methods to calculate bed shear stress. I.A.W.P.R.C., Water Science and Technology, Vol. 25, No. 8, pp. 131-140, 1992.

TORFS H. Sedimenttransport meetcampagne op de Schelde nabij Temse. Water, Vol. 11, No. 63, Maart/April 1992.

TORFS $H$. Erosional behaviour of partly cohesive, partly non cohesive sediments in uniform flow. Proceedings of the 6th International Conference on Urban Storm Drainage, Niagara Falls, Ontario, Canada, September 12-17, 1993.

TORFS H. and HUYGENS M. Erosion of partly cohesive, partly non cohesive sediments in uniform flow. In Advances in Hydro-Science and -Engineering, S. Wang ed., 1993.

TORFS H., HUYGENS M. and TITO L. Influence of the cross section on the erosion criteria of partly cohesive sediments. I.A.W.Q., Water Science and Technology, Vol. 29, No. 1-2, pp. 103-111, 1994. 
TORFS H. Shape and scale effects on secondary currents and shear stress distributions in laboratory flumes. 2nd International Conference on Hydraulic Modelling, Development and Application of Physical and Mathematical Models, Stratford-upon-Avon, 14-16 June, 1994.

TORFS H. Erosion of mixed cohesive/non cohesive sediments in uniform flow. 4th Nearshore and Estuarine Cohesive Sediment Transport Conference INTERCOH '94, 11-15 July, Wallingford, England, 1994.

TORFS H. Erosion of layered sand-mud beds in uniform flow. Proceedings of the 24th International Conference on Coastal Engineering, Kobe, Japan, 23-28 October 1994.

TORFS H., WILLIAMSON H. and HUYSENTRUYT H. Settling and erosion characteristics of mud/sand mixtures. Coastal Dynamics '95, Gdansk, September 1995.

TORFS H., WILLIAMSON H. and HUYSENTRUYT H. Settling and consolidation of mud/sand mixtures. Submitted to Journal of Coastal Engineering, June 1995.

WILLIAMSON H. and TORFS H. Erosion of mud/sand mixtures. Submitted to Journal of Coastal Engineering, June 1995. 
